\title{
EDILSON ERVOLINO
}

\author{
INERVAÇÃO AUTONÔMICA DA ARTICULAÇÃO \\ TEMPOROMANDIBULAR EM CONDIÇÕES DE NORMALIDADE \\ E, PADRÃO DE ATIVAÇÃO NEURONAL NO TRONCO \\ ENCEFÁLICO DURANTE A VIGÊNCIA DE ARTRITE NO \\ COMPLEXO ARTICULAR TEMPOROMANDIBULAR
}

Tese de doutorado apresentada ao Instituto de Ciências Biomédicas da Universidade de São Paulo, para obtenção do título de doutor em Ciências.

Área de concentração: Biologia Celular e Tecidual

São Paulo

2009 


\section{EDILSON ERVOLINO}

\section{INERVAÇÃO AUTONÔMICA DA ARTICULAÇÃO \\ TEMPOROMANDIBULAR EM CONDIÇÕES DE NORMALIDADE E, PADRÃO DE ATIVAÇÃO NEURONAL NO TRONCO ENCEFÁLICO DURANTE A VIGÊNCIA DE ARTRITE NO COMPLEXO ARTICULAR TEMPOROMANDIBULAR}

Tese de doutorado apresentada ao Instituto de Ciências Biomédicas da Universidade de São Paulo, para obtenção do título de doutor em Ciências.

Área de concentração: Biologia Celular e Tecidual

Orientador: Prof. Dr. Jarbas Arruda Bauer

São Paulo

2009 


\section{DADOS DE CATALOGAÇÃO NA PUBLICAÇÃO (CIP)}

Serviço de Biblioteca e Informação Biomédica do

Instituto de Ciências Biomédicas da Universidade de São Paulo

reprodução não autorizada pelo autor

Ervolino, Edilson.

Inervação autonômica da articulação temporomandibular em condições de normalidade e, padrão de ativação neuronal no tronco encefálico durante a vigência de artrite no complexo articular temporomandibular / Edilson Ervolino. -- São Paulo, 2009.

Orientador: Jarbas Arruda Bauer.

Tese (Doutorado) - Universidade de São Paulo. Instituto de Ciências Biomédicas. Departamento de Biologia Celular e do Desenvolvimento. Área de concentração: Biologia Celular e Tecidual. Linha de pesquisa: Neurobiologia do sistema trigeminal.

Versão do título para o inglês: Temporomandibular joint autonomic innervation under normal conditions and, neuronal activation pattern in the brain stem during monoarthritis induced in the temporomandibular joint complex.

Descritores: 1. Articulação temporomandibular 2. Fibras nervosas simpáticas 3. Fibras nervosas parassimpáticas 4 . Artrite 5 . Sistema trigeminal 6. Sistema de modulação da dor I. Bauer, Jarbas Arruda II. Universidade de São Paulo. Instituto de Ciências Biomédicas.

Programa de Pós Graduação em Biologia Celular e Tecidual III. Título. 


\title{
UNIVERSIDADE DE SÃO PAULO \\ INSTITUTO DE CIÊNCIAS BIOMÉDICAS
}

\begin{abstract}
Candidato(a): $\quad$ Edilson Ervolino.
Título da Tese:

Inervação autonômica da articulação temporomandibular em condições de normalidade e, padrão de ativação neuronal no tronco encefálico durante a vigência de artrite no complexo articular temporomandibular.
\end{abstract}

Orientador(a): Jarbas Arruda Bauer.

A Comissão Julgadora dos trabalhos de Defesa da Tese de Doutorado, em sessão pública realizada a I... , considerou

\section{( ) Aprovado(a) $\quad$ ( ) Reprovado(a)}

$\begin{array}{ll}\text { Examinador(a): } & \begin{array}{l}\text { Assinatura: } \\ \text { Nome: }\end{array} \\ \text { Instituição: } & \begin{array}{l}\text { Assinatura: } \\ \text { Exame: } \\ \text { Instituição: }\end{array} \\ \text { Examinador(a): } & \begin{array}{l}\text { Assinatura: } \\ \text { Nome: } \\ \text { Exstituição: }\end{array} \\ & \begin{array}{l}\text { Assinatura: } \\ \text { Nome: }\end{array} \\ & \text { Instituição: }\end{array}$




\section{UNIVERSIDADE ESTADUAL PAULISTA}

"Júlio de Mesquita Filho"

Campus de Araçatuba

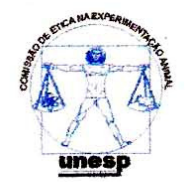

COMISSÃO DE ÉTICA NA EXPERIMENTAÇÃO ANIMAL

(CEEA)

C E R T I F I C A D O

Certificamos que o Projeto "ANÁLISE SISTEMÁTICA DAS ÁREAS DO SISTEMA NERVOSO CENTRAL ATIVADAS DURANTE A VIGÊNCIA DE ARTRITE INDUZIDA NA ARTICULAÇÃO TEMPOROMANDIBULAR (ATM) DO RATO" SOb responsabilidade de EDILSON ERVOLINO, CLÁUDIO APARECIDO CASATII, ROELF JUSTINO CRUZ RIZZOLO, DANIELA SABINO BATAGELLO E KELLY REGINA TORRES está de acordo com os Princípios Éticos na Experimentação Animal adotado pelo Colégio Brasileiro de Experimentação Animal (COBEA) e foi aprovado pela CEEA em reuniáo de 19 de maio de 2005, de acordo com o protocolo no $57 / 05$.

Araçatuba, 19 de maio de 2005.

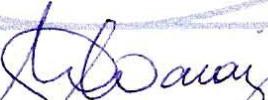

Prof.a Ass. Dr.a Maria Gisela Laranjeira

Presidente 
À Deus... 
À minha Renata e ao meu Pedro pelo amor incondicional. 


\section{AGRADECIMENTOS}

Ao meu orientador, Prof. Dr. Jarbas Arruda Bauer, pela paciência, pelos ensinamentos, pela atenção e pelo bom exemplo.

Ao meu amigo, Prof. Dr. Cláudio Aparecido Casatti, por ter me guiado durante todo este período e estar sempre disposto a me ajudar.

Aos professores e funcionários do Departamento de Ciências Básicas da Faculdade de Odontologia de Araçatuba, em especial ao Prof. Dr. Roelf Justino Cruz-Rizzolo, Profa. Dra. Alaíde Gonçalves e Prof. Dr. Fausto Marchi.

Aos professores do Departamento de Biologia Celular e do Desenvolvimento do Instituto de Ciências Biomédicas da Universidade de São Paulo, em especial à Profa. Dra. Dânia Emi Hamassaki pela dedicação exemplar na Cordenadoria do Curso de Pós-Graduação em Biologia Celular e Tecidual.

Aos funcionários da Biblioteca do Instituto de Ciências Biomédicas da Universidade de São Paulo.

À preciosa ajuda e amizade de Kelly Regina Torres, Daniella Sabino Batagello e Alexandre Denadai-Souza.

À Karina Vieira Casatti pela paciência e traduções instantâneas.

À UNESP, UNIPAR e FUNEC.

Aos meus pais, Walter e Aparecida, e as minhas irmãs, Beatriz e Vanessa pelos ensinamentos e pelo amor.

À minha avó Durvalina Felipetti Ervolino e a minhas tias, por tudo.

Ao Marini, Cleuza e Guto, por todo o apoio. 


\section{RESUMO}

ERVOLINO, E. Inervação autonômica da articulação temporomandibular em condições de normalidade e, padrão de ativação neuronal no tronco encefálico durante a vigência de artrite no complexo articular temporomandibular. 2009. 146 f. Tese (Doutorado em Biologia Celular e Tecidual) - Instituto de Ciências Biomédicas, Universidade de São Paulo, São Paulo, 2009.

Os objetivos do presente trabalho foram: 1) analisar a distribuição das fibras nervosas autonômicas na articulação temporomandibular (ATM) do rato, através da detecção de tirosina hidroxilase (TH), neuropeptídeo Y (NPY) e peptídeo intestinal vasoativo (VIP); 2) realizar um estudo topográfico ultra-estrutural das fibras e terminações nervosas autonômicas na ATM do rato; 3) determinar o padrão de ativação neuronal no complexo nuclear trigeminal e, em centros nervosos moduladores da dor, durante a vigência de monoartrite no complexo articular temporomandibular (CATM) do rato. Para o primeiro propósito o método imunoistoquímico, para a detecção simultânea de TH, NPY e VIP, foi executado em ATMs que apresentavam as seguintes condições: inervação intacta ou desprovida de inervação simpática e/ou parassimpática. Para o segundo propósito aliamos o tratamento prévio com 5-hidroxidopamina, para evidenciação de terminações nervosas simpáticas, com a remoção cirúrgica do gânglio ótico, para a visualização das fibras e terminações nervosas parassimpáticas em degeneração, em seguida analisamos as ATMs ao microscópio eletrônico de transmissão. O terceiro propósito foi obtido induzindo-se monoartrite (fase aguda, crônica e crônica ativa) no CATM e, verificando a expressão de Fos, um marcador de ativação neuronal, no complexo nuclear sensorial trigeminal e nos principais centros nervosos moduladores da dor, situados no tronco encefálico (substância cinzenta periaqueductal- PAG; área rostral ventromedial da medula oblonga- RVM; locus coeruleus- LC; área caudal ventrolateral da medula oblonga- CVLM; núcleo do trato solitário- NTS e; núcleo reticular ventralNRV). Verificamos que as ATMs desprovidas de inervação simpática apresentam exclusivamente uma pequena quantidade de fibras nervosas VIP-IR, ao passo que aquelas desprovidas de inervação parassimpática mostram uma grande quantidade de fibras nervosas TH/NPY-IR e TH/NPY/VIP-IR. As fibras e terminações nervosas autonômicas foram observadas em vasos sanguíneos ou isoladas no tecido conjuntivo, especialmente na membrana sinovial. No que se refere à expressão de Fos, constatamos que o subnúcleo caudal do núcleo do tracto espinal do nervo trigêmeo (Sp5C) e a PAG apresentaram um aumento bilateral significante na expressão de Fos durante todas as fases da monoartrite induzida no CATM. Todavia, RVM, LC, CVLM, NTS apresentaram uma quantidade de neurônios Fos-IR significativamente aumentada, de ambos os lados, apenas quando o CATM estava sob vigência de monoartrite na fase aguda e crônica ativa. Concluímos que: 1) a ATM mostra-se densamente inervada por fibras nervosas simpáticas (TH/NPY-IR e TH/NPY/VIP-IR) e, por uma discreta quantidade de fibras nervosas parassimpáticas (VIP-IR), ambas predominantemente associadas com vasos sanguíneos; 2) o Sp5C e a PAG, mostra-se intensamente ativados em todas as fases da monoartrite no CATM, ao passo que a maioria dos centros nervosos moduladores da dor apresentam uma quantidade aumentada de neurônios imunoarreativos ao marcador de ativação neuronal, Fos, apenas durante as fases aguda e crônica ativa dessa monoartrite.

Palavras-chave: Articulação temporomandibular. Fibras nervosas simpáticas. Fibras nervosas parassimpáticas. Artrite. Sistema trigeminal. Sistema endógeno de modulação da dor. Rato. 


\begin{abstract}
ERVOLINO, E. Temporomandibular joint autonomic innervation under normal conditions and, neuronal activation pattern in the brain stem during monoarthritis induced in the temporomandibular joint complex. 2009. $146 \mathrm{p}$. Ph. D. Thesis (Cell and Tissue Biology). Institute of Biomedical Sciences, University of São Paulo, São Paulo, 2009.
\end{abstract}

The goals of the present study were: 1) to analyse the distribution of autonomic nerve fibers in the rat temporomandibular joint (TMJ) under normal conditions using immunofluorescence method to detect tirosyne hydroxylase (TH), neuropetide $Y$ (NPY) and vasoactive intestinal polypeptide (VIP); 2) to verify the detailed distribution of autonomic nerve fibers in the rat temporomandibular joint by transmission electron microscopy; 3 ) to determine the neuronal activation pattern in the trigeminal system and in the pain modulation centers during monoarthritis induced in the rat temporomandibular joint complex (TMJC). For the first purpose, histologic sections from TMJs with intact innervation or with surgical sympatectomy and/or parasympathectomy were submitted to simultaneous detection of TH, NPY and VIP. For the second purpose, 5hydroxidopamine treatment to detect sympathetic nerve endings was combined with surgical parasympatectomy of the otic ganglion to detect degenerated parasympathetic nerve endings in the rat TMJC, by transmission electron microscopy. For the last purpose, monoarthritis (acute, chronic and chronic-active phases) was induced in the TMJC and histologic sections from the brain stem were submitted to immunodetection of Fos protein in the trigeminal system and in the pain modulation centers (periqueductal gray matter - PAG; rostroventromedial medulla - RVM; locus coeruleus- LC; caudal ventrolateral medulla- CVLM; nucleus of the solitary tract - NTS; ventral reticular nucleus - VRN). The most important results demonstrated that the TMJC showed a discrete parasympathetic innervation (VIP-IR), while the sympathetic innervation was dense and characterized by TH-/NPY-/VIP-IR or TH-/NPY-IR nerve fibers. Autonomic nerve fibers were mainly noted associated to blood vessels and occasionally disperse in the synovial membrane. Fos-IR neurons showed significant bilateral increase in the spinal trigeminal caudal subnucleus and PAG during arthritis evolution. On the other hand, RVM, LC, CVLM and NTS only showed significant increase of Fos-IR neurons during the acute and chronic-active phases of monoarthritis. The main conclusions were: 1) the TMJC shows a dense sympathetic innervation (TH/NPY-IR or TH-/NPY-/VIP-IR) and discrete parasympathetic innervation (VIP-IR), both associated mainly to blood vessels; 2) most modulation pain centers are activated principally during acute and chronic-active arthritis, while the spinal trigeminal caudal subnucleus and PAG showed continuous activation during all phases of arthritis.

Key words: Temporomandibular joint. Sympathetic nerve fibers. Parasympathetic nerve fibers. Arthritis. Trigeminal system. Pain modulation system. Rat. 


\section{LISTA DE FIGURAS}

Figura 1. Representação esquemática da articulação temporomandibular evidenciando seus principais constituintes.

Figura 2. Fotomicrografia das superfícies articulares e do disco articular da articulação temporomandibular corados por hematoxilina $e$ eosina.......

Figura 3. Fotomicrografia do disco articular da articulação temporomandibular corado por hematoxilina e eosina.

Figura 4. Fotomicrografia da membrana sinovial da articulação temporomandibular corada por hematoxilina e eosina.

Figura 5. Esquema resumindo o delineamento experimental descrito em 1.2 .2

Figura 6. Esquema resumindo o delineamento experimental descrito em 1.2.3.

Figura 7. Fotomicrografia (epifluorescência) de um vaso sanguíneo envolto por fibras nervosas TH/NPY/VIP-IR.

Figura 8. Fotomicrografia (epifluorescência) de fibra nervosa TH/NPY-IR na membrana sinovial e de fibra nervosa VIP-IR na circunjacência de um vaso sanguíneo

Figura 9. Elétron-micrografia de fibras e terminações nervosas sensoriais e autonômicas situadas nos ligamentos intra-articulares da ATM do rato.

Figura 10. Esquema resumindo o delineamento experimental descrito em 2.2.1

Figura 11. Esquema resumindo o procedimento de análise dos dados descritos em 2.2.2.

Figura 12. Imunomarcação para Fos no subnúcleo caudal do núcleo do trato espinal do nervo trigêmeo (Sp5C).

Figura 13. Gráfico evidenciando o efeito da monoartrite no CATM (fases: aguda, crônica e crônica ativa) na expressão de Fos no Sp5C...

Figura 14. Gráfico evidenciando o efeito da monoartrite no CATM (fases: aguda, crônica e crônica ativa) na expressão de Fos na PAG..... 90 
Figura 15. Representação esquemática de uma secção transversal do tronco encefálico do rato, em nível da PAG.

Figura 16. Imunomarcação para Fos na substância cinzenta periaqueductal (PAG)

Figura 17. Imunomarcação para Fos na área rostral ventromedial da medula oblonga (RVM).

Figura 18. Gráfico evidenciando o efeito da monoartrite no CATM (fases: aguda, crônica e crônica ativa) na expressão de Fos na RVM....

Figura 19. Imunomarcação para Fos na área caudal ventrolateral da medula oblonga (CVLM).

Figura 20. Gráfico evidenciando o efeito da monoartrite no CATM (fases: aguda, crônica e crônica ativa) na expressão de Fos na CVLM.. 95

Figura 21. Imunomarcação para Fos no locus coeruleus (LC).................... 96

Figura 22. Gráfico evidenciando o efeito da monoartrite no CATM (fases: aguda, crônica e crônica ativa) na expressão de Fos no LC........ 97

Figura 23. Imunomarcação para Fos no núcleo do trato solitário (NTS)....... 98

Figura 24. Gráfico evidenciando o efeito da monoartrite no CATM (fases: aguda, crônica e crônica ativa) na expressão de Fos no NTS.....

Figura 25. Gráfico evidenciando o efeito da monoartrite no CATM (fases: aguda, crônica e crônica ativa) na expressão de Fos no NRV.

Figura 26. Fotomicrografias (microscopia de luz) de cortes histológicos frontais de ATMs, corados com hematoxilina e eosina, pertencentes aos diferentes grupos controle e experimentais..... 


\section{LISTA DE TABELAS}

Tabela 1. Diferentes componentes da ATM do rato e seu respectivo padrão de imunorreatividade nos grupos controle e experimentais.. 


\section{LISTA DE ABREVIATURAS}

AMCA 7-amino 4-metil coumarin 3-ácido acético

ATM articulação temporomandibular

CAR Carragenina

CATM complexo articular temporomandibular

CFA adjuvante de Freund completo

CGRP peptídeo relacionado ao gene da calcitonina

CVLM área caudal ventrolateral da medula oblonga

DTAF diclorotriazinolamino fluoresceína

DTMs desordens temporomandibulares

-IR Imunorreativo

KPBS tampão fosfato de potássio

LC locus coeruleus

M5 núcleo do trato mesencefálico do nervo trigêmeo

NPY neuropeptídeo Y

NRV núcleo reticular ventral

NTS núcleo do trato solitário

P5 núcleo sensitivo principal do nervo trigêmeo

PAG substância cinzenta periaqueductal

RVM área rostral ventromedial da medula oblonga

SOM Somatostatina

SP substância $P$

Sp5C subnúcleo caudal do núcleo do trato espinal do nervo trigêmeo

Sp5I subnúcleo interpolar do núcleo do trato espinal do nervo trigêmeo

Sp50 subnúcleo oral do núcleo do trato espinal do nervo trigêmeo

TH tirosina hidroxilase

VIP peptídeo intestinal vasoativo

5- OHDA 5 - hidroxidopamina 


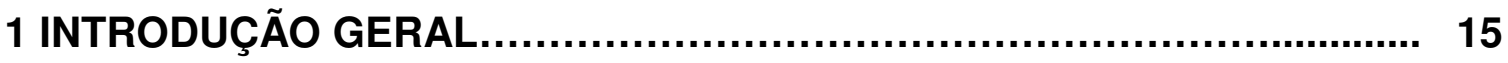

1.1 Histofisiologia da articulação temporomandibular............................... 16

1.2 Inervação da articulação temporomandibular....................................... 22

1.3 Artrite na articulação temporomandibular e seus modelos experimentais.

1.4 A dor na articulação temporomandibular e a via trigeminal nociceptiva.

2 CAPÍTULOS

CAPÍTULO 1: Caracterização neuroquímica e ultra-estrutural das fibras e terminações nervosas autonômicas da articulação temporomandibular do rato.

1.1 INTRODUÇÃO

1.2. MATERIAL E MÉTODO..................................................................... 39

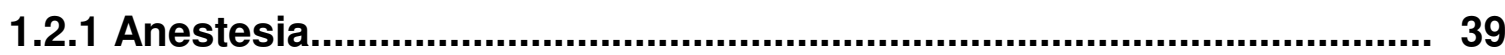

1.2.2 Delineamento experimental 1: Caracterização neuroquímica das fibras e terminações nervosas autonômicas na ATM.

1.2.3 Delineamento experimental 2: Análise topográfica ultra-estrutural das fibras e terminações nervosas autonômicas na ATM.

1.3. RESULTADOS

1.3.1 Caracterização neuroquímica das fibras e terminações nervosas autonômicas que inervam a ATM do rato.

1.3.2 Análise topográfica ultra-estrutural das fibras e terminações nervosas autonômicas na ATM do rato....................................................

1.3.3 Documentação fotográfica.................................................................. 50

1.4. DISCUSSÃO.

1.4.1 Caracterização neuroquímica das fibras e terminações nervosas autonômicas que inervam a ATM do rato..

1.4.2 Análise topográfica ultra-estrutural das fibras e terminações nervosas autonômicas na ATM do rato.

CAPÍTULO 2: Padrão de ativação neuronal no complexo nuclear trigeminal e no sistema endógeno de modulação da dor durante a vigência de monoartrite na articulação temporomandibular do rato.

2.2.1 Delineamento experimental.

2.2.2 Preparação das amostras submetidas a reação imunoistoquímica para detecção de Fos ou a coloração de Nissl. 
2.2.3 Analise dos dados..................................................................... 80

2.2.4 Preparação das ATMs para exame histopatológico............................ 82

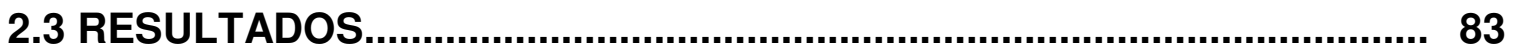

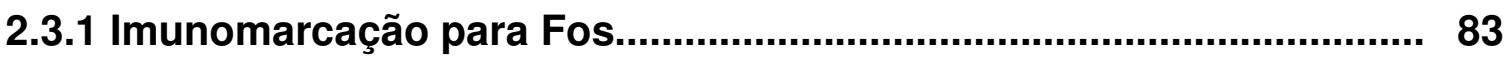

2.3.2 Análise histopatológica das ATMs................................................. 86

2.3.3 Documentação fotográfica............................................................. 87

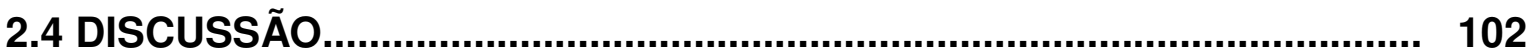

2.4.1 Considerações metodológicas.................................................... 102

2.4.2 Imunomarcação para Fos no complexo nuclear trigeminal sensorial após monoartrite induzida no CATM....................................... 105 2.4.3 Imunomarcação para Fos no sistema endógeno de modulação da dor após monoartrite induzida no CATM.................................................... 109

4. CONCLUSÕES GERAIS........................................................ 118

REFERÊNCIAS BIBLIOGRÁFICAS.................................................. 119 
1 INTRODUÇÃO GERAL 


\subsection{Histofisiologia da articulação temporomandibular}

O complexo articular temporomandibular (CATM) é composto por duas articulações localizadas bilateralmente no plano frontal da cabeça, equidistantes da linha sagital mediana e, responsáveis pelos amplos movimentos que a mandíbula executa em relação aos ossos temporais. Embora cada uma destas articulações tenha sua identidade anatômica, estão atreladas funcionalmente, uma vez que não é possível a realização de movimentos independentes por cada uma delas. As articulações temporomandibulares (ATMs) são classificadas como articulações sinoviais, onde uma cápsula de tecido conjuntivo denso confina os componentes ósseos e define o espaço articular, separado pelo disco articular, e que encerra o líquido sinovial (Fig. 1). A produção desse líquido é dependente de uma membrana sinovial constituída por células conjuntivas especializadas, que revestem grande parte da superfície interna da cápsula articular, os ligamentos intra-articulares e, a porção periférica do disco articular.

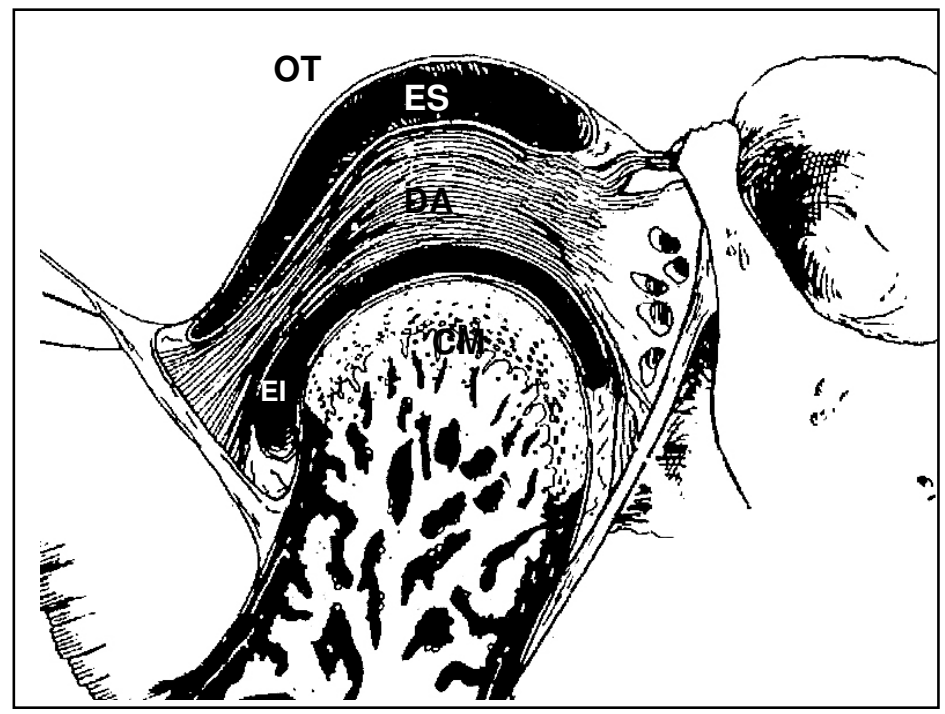

Figura 1. Representação esquemática da articulação temporomandibular (ATM) (corte sagital) evidenciando seus principais constituintes. Abreviações: CM: côndilo da mandíbula; El: compartimento infradiscal do espaço articular; DA: disco articular; ES: compartimento supradiscal do espaço articular; OT: osso temporal.

FONTE: modificado de AVERY J. K. Oral Development and Histology. New York: Thieme Medical Publishers, 2002.

Embora tanto a anatomia macro e microscópica, como as principais características fisiológicas da ATM de diferentes mamíferos sejam muito semelhantes, algumas peculiaridades espécie-específicas são observadas. Sendo 
assim, descreveremos as principais características gerais desta articulação, as quais são comuns a grande maioria dos mamíferos e quando existentes, chamaremos a atenção para algumas peculiaridades observadas na ATM humana e na do rato, a qual foi explorada em nosso estudo.

Na maioria dos mamíferos, incluindo o homem, as superfícies ósseas que se relacionam para compor cada uma das ATMs são: o côndilo da mandíbula, a eminência articular e a fossa mandibular do osso temporal (NOBLE et al., 1973; POIGNONEC et al., 1990; PIETTE, 1993). Do ponto de vista anatômico, a ATM do rato apresenta-se estruturalmente mais simples, sendo composta pelo côndilo da mandíbula e por uma superfície do osso temporal desprovida de acidentes anatômicos nítidos (NOBLE et al., 1973).

Essas superfícies ósseas mostram-se revestidas por algumas camadas de tecido mole, que variam em termos quantitativos e qualitativos, dependendo da idade e do local analisado. Sendo assim, inicialmente consideraremos o revestimento articular de uma articulação ainda em fase de crescimento, onde as superfícies ósseas apresentam-se revestidas pelas seguintes camadas teciduais, a partir da superfície articular em direção ao tecido ósseo: camada fibrosa, constituída por tecido conjuntivo denso modelado avascular, caracterizado por apresentar feixes espessos de fibras colágenas do tipo I e escassos fibroblastos (GRIFFIN et al., 1975; WILSON et al., 1984; PIRTTINIEMI et al., 1996; BENJAMIN et al., 2004); camada proliferativa, uma camada de espessura variada, descontínua em alguns locais, composta por numerosas células indiferenciadas, potencialmente capazes de se diferenciarem em fibroblastos ou em condrócitos, portanto fornecendo células para a camada fibrosa e para a camada mais profunda, a camada cartilaginosa (GRIFFIN et al., 1975; WILSON et al., 1984; BOUVEIER, 1988); camada cartilaginosa, composta por tecido cartilaginoso hialino, cuja matriz extracelular é constituída por grande quantidade de proteoglicanas, glicoproteínas e fibrilas de colágeno do tipo II, produtos da intensa atividade dos condrócitos dessa região (GRIFFIN et al., 1975; WILSON et al., 1984; MILAM et al., 1991; PIRTTINIEMI et al., 1996) (Fig. 2). A cartilagem hialina desse território está em franco processo de ossificação endocondral, o qual é fundamental para o crescimento radial do côndilo da mandíbula e da superfície articular do osso temporal. $O$ processo de ossificação endocondral nessa região é caracterizado inicialmente por uma intensa proliferação 
e, posterior hipertrofia dos condrócitos, os quais, após a mineralização dos finos tabiques de matriz cartilaginosa, entram em apoptose. Nesse momento a matriz cartilaginosa mineralizada é invadida por vasos sanguíneos, linfáticos e células indiferenciadas advindos dos tecidos conjuntivos adjacentes. As células indiferenciadas se diferenciam em osteoblastos, os quais secretarão a matriz óssea sobre os suportes de cartilagem mineralizada. Vale a pena salientar que a proliferação dos condrócitos nessa região obedece aos mais variados planos de orientação, em função disso o crescimento deste território é multidirecional (GRIFFIN et al., 1975; WILSON et al., 1984; POIGNONEC et al., 1990).

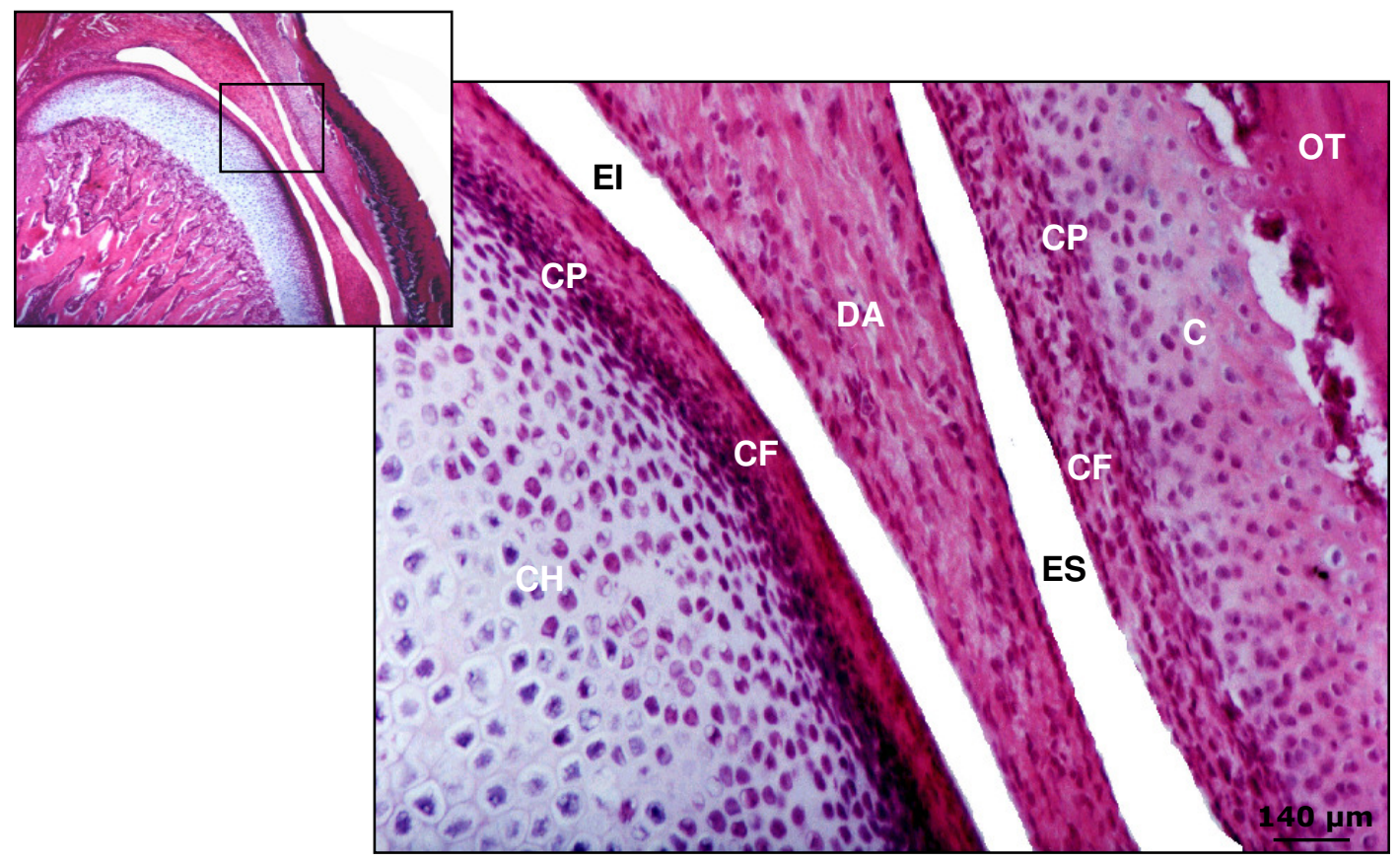

Figura 2. Fotomicrografia das superfícies articulares e do disco articular da articulação temporomandibular corados por hematoxilina e eosina. Abreviações: $\mathrm{CH}$ : cartilagem hialina; CP: camada proliferativa; CF: camada fibrosa; El: compartimento infradiscal do espaço articular; DA: disco articular; ES: compartimento supradiscal do espaço articular; C: cartilagem fibrosa; OT: osso temporal. A fotomicrografia anexada ao lado evidencia a região que está sendo observada em maior aumento.

Uma vez cessado o crescimento ocorrem alterações quantitativas e qualitativas no revestimento das superfícies ósseas da ATM. A camada fibrosa pouco se modifica, e quando ocorre, as alterações restringem-se basicamente a um aumento de sua espessura. A camada proliferativa sofre uma substancial redução, tornando-se descontínua em vários territórios. A camada que anteriormente era composta por cartilagem do tipo hialina, à medida que cessa o processo de 
ossificação endocondral, vai sendo substituída por uma camada de cartilagem fibrosa (fibrocartilagem), constituída por espessos feixes de fibras colágenas do tipo I entre os quais se distribuem os raros condrócitos. Essa fibrocartilagem, normalmente se apóia em uma faixa de espessura variável de cartilagem mineralizada, que por sua vez se continua com o tecido ósseo, do côndilo mandibular ou da superfície articular do osso temporal (WILSON et al., 1984; PIRTTINIEMI et al., 1996; BENJAMIN et al., 2004).

Deve ser salientado que após o crescimento dessa região ter cessado, ainda continua uma intensa atividade de remodelação óssea na ATM, que é influenciada sobremaneira por mudanças funcionais na dinâmica do aparelho estomatognático que ocorrem no decorrer da vida (CHRISTENSEN e ZIEBERT, 1986; CASCONE et al., 1999). Deve-se pensar na relação que a ATM tem com os dentes, com a falta deles ou, no caso do homem, com restaurações e reposição protética dos mesmos (CHRISTENSEN e ZIEBERT, 1986; CASCONE et al., 1999). Portanto, as modificações oclusais podem repercutir com maior ou menor relevância na estrutura da ATM.

Entre as superfícies articulares observa-se o disco articular, que se mostra macroscopicamente como uma estrutura fibrosa discóide, com maior diâmetro médio-lateral em primatas e, maior diâmetro ântero-posterior em roedores (BERMEJO et al., 1993). O disco articular é constituído por tecido conjuntivo denso, cuja matriz extracelular fibrilar é constituída por colágeno do tipo I e III (CARVALHO et al., 1993; NATIELLA et al., 2009), além de uma rede de fibras elásticas (SUN et al., 1997) e oxitalânicas (BOOJl e MARKENS, 1983). As células responsáveis pela produção dessa matriz extracelular são fibroblastos e escassas células condróides (KIM e PAIK, 1985; BERKOVITZ e PACY, 2000). A porção central do disco articular é delgada e avascular, enquanto a porção periférica é espessa, vascularizada e ricamente inervada (BERMEJO et al., 1993) (Fig. 3).

O disco articular mantem-se posicionado por intermédio dos ligamentos intraarticulares (medial, lateral, anterior e posterior), contínuos com sua porção periférica e, inseridos basicamente no colo do côndilo da mandíbula e cápsula articular (BADE et al., 1994). São constituídos por tecido conjuntivo moderadamente denso, entremeado por áreas de tecido adiposo e conjuntivo frouxo, ricamente inervados e vascularizados (BADE et al., 1994). 
O complexo articular é envolvido por uma cápsula de tecido conjuntivo que varia de denso a moderadamente denso, a qual delimita o espaço articular que, por sua vez é subdividido pelo disco articular e ligamentos intrínsecos em compartimento supradiscal e infradiscal (NOBLE et al., 1973; POIGNONEC et al., 1990; PIETTE, 1993; CASCONE et al., 1999).

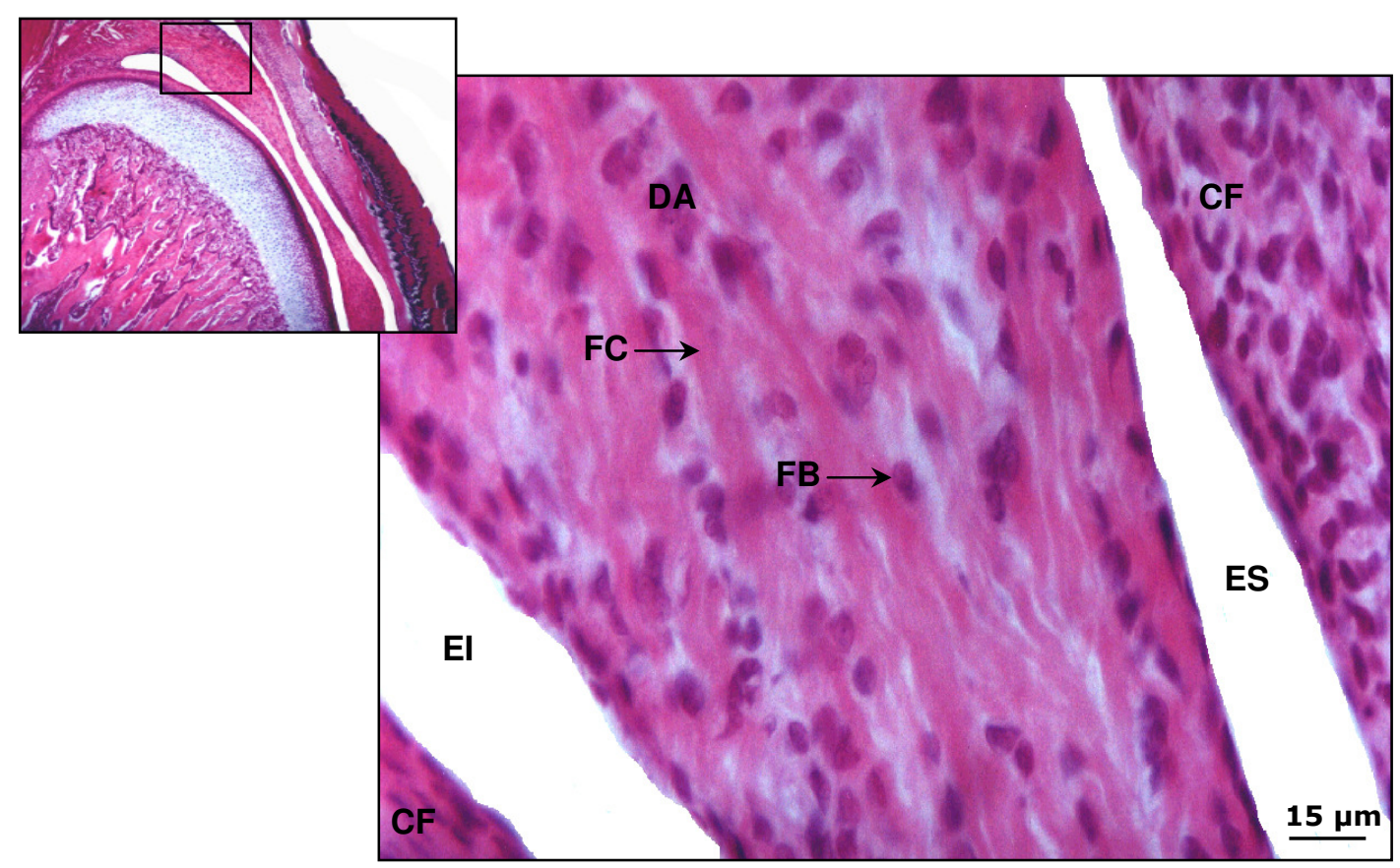

Figura 3. Fotomicrografia do disco articular da articulação temporomandibular corado por hematoxilina e eosina. Abreviações: CF: camada fibrosa; El: compartimento infradiscal do espaço articular; DA: disco articular; ES: compartimento supradiscal do espaço articular; FC: fibras colágenas; FB: fibroblastos. A fotomicrografia anexada ao lado evidencia a região que está sendo observada em maior aumento.

A superfície interna da cápsula articular, os ligamentos intra-articulares e, a porção periférica do disco articular, são revestidos pela membrana sinovial. A membrana sinovial consiste de uma camada superficial de células conjuntivas, denominada íntima, que se apóia sobre uma camada de tecido conjuntivo frouxo densamente vascularizado e inervado, denominada subíntima (NOBLE et al., 1973; POIGNONEC et al., 1990; PIETTE, 1993; CASCONE et al., 1999) (Fig. 4). A camada íntima é composta de um a quatro estratos de células conjuntivas, muito próximas umas das outras, envoltas por uma matriz extracelular constituída por abundante quantidade de substância fundamental e esparsos feixes de fibrilas colágenas (DIJKGRAAF et al., 1996a; DIJKGRAAF et al., 1996b; NOZAWA-INOUE 
et al., 2003) (Fig. 4). A ultra-estrutura da camada íntima da membrana sinovial permite a classificação de dois tipos celulares: células fagocitárias (células $A$ ou $M$ ) e, células com intensa atividade de síntese de proteínas de exportação (células $B$ ou F) (DIJKGRAAF et al., 1996a; DIJKGRAAF et al., 1996b; NOZAWA-INOUE et al., 2003).

O líquido sinovial que preenche as cavidades articulares é constituído pelo líquido intersticial, proveniente dos capilares fenestrados da camada subíntima, que ao se difundir pela camada íntima, em direção à cavidade articular, é adicionado de proteoglicanas, glicoproteínas e glicosaminoglicanas, produtos da secreção das células $B$ ou $F$. As células $A$ ou $M$ caracterizam-se por exercerem intensa atividade de pinocitose do líquido sinovial, colaborando sobremaneira para sua renovação. A água e moléculas de baixo peso molecular retornam à circulação através dos vasos linfáticos e da porção venosa dos capilares sanguíneos presentes na camada subíntima (IWANAGA et al., 2000). O fluido sinovial mantém as superfícies articulares em um ambiente lubrificado, que além de impedir a adesão e o desgaste dos componentes internos da articulação, colabora com a nutrição das células de territórios avasculares (DIJKGRAAF et al., 1996a; DIJKGRAAF et al., 1996b; CASCONE et al., 1999; NOZAWA-INOUE et al., 2003).

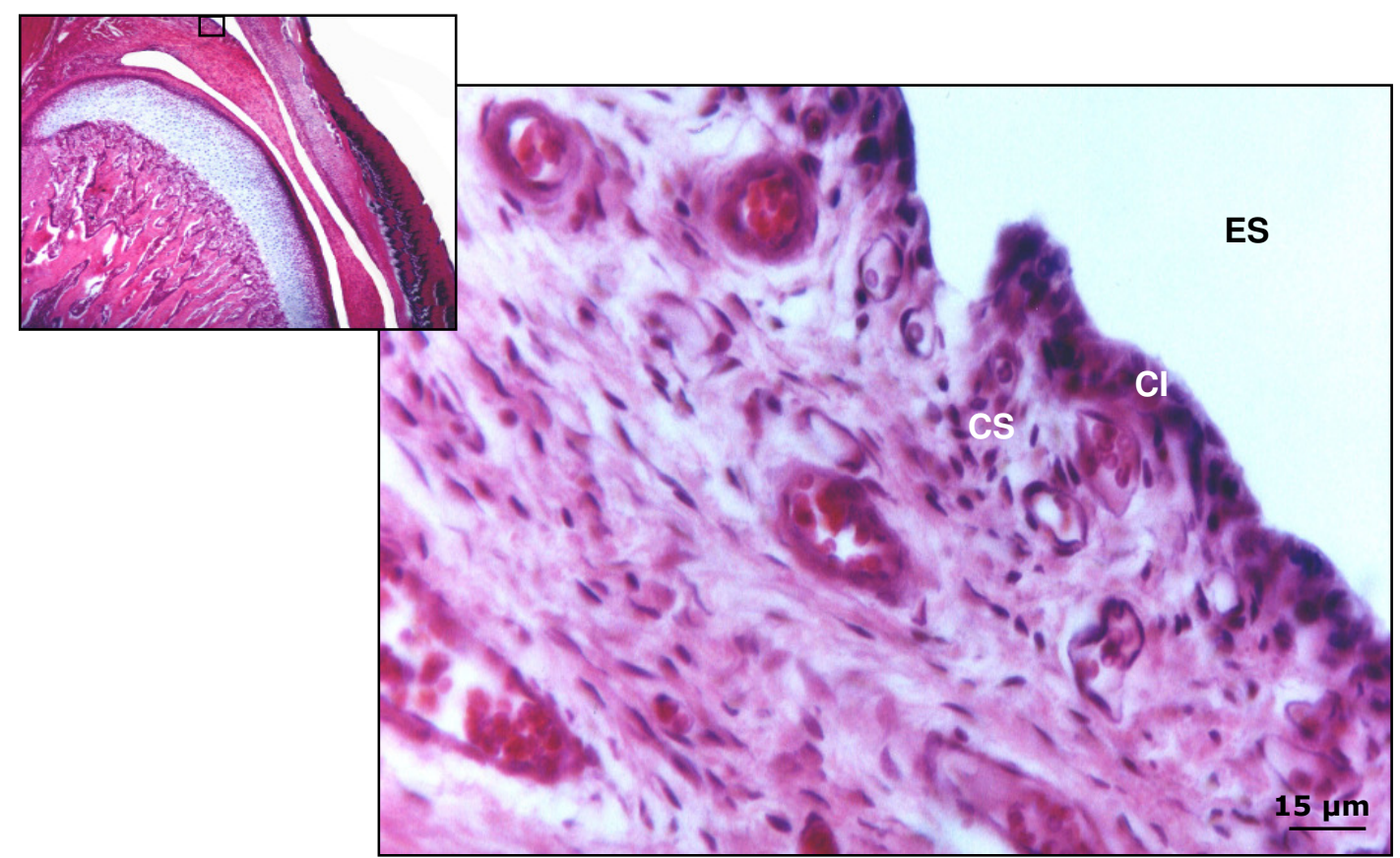

Figura 4. Fotomicrografia da membrana sinovial da articulação temporomandibular corada por hematoxilina e eosina. Abreviações: CS: camada subíntima da membrana sinovial; Cl: camada íntima da membrana sinovial; ES: compartimento supradiscal do espaço articular. A fotomicrografia anexada ao lado evidencia a região que está sendo observada em maior aumento. 


\subsection{Inervação da articulação temporomandibular}

A ATM é um território densamente inervado por fibras nervosas sensitivas e autonômicas, especialmente na cápsula articular, nos ligamentos intra-articulares e, na periferia do disco articular (ICHIKAWA et al., 1989; KIDO et al., 1993; MORANI et al., 1994; SHIMIZU et al., 1996; SCHIMIDT et al., 1998; UDDMAN et al., 1998; HAEUCHI et al., 1999; YOSHIDA et al., 1999; KIDO et al., 2001).

As fibras nervosas sensitivas, responsáveis pela inervação da ATM do rato, consistem de prolongamentos periféricos de neurônios localizados, predominantemente, no gânglio trigeminal e, uma discreta quantidade nos gânglios sensitivos das raízes dorsais da medula espinal (C2 a C5) (WIDENFALK e WIBERG, 1990; UDDMAN et al., 1998; YOSHINO et al., 1998; CASATTI et al., 1999) e, relacionam-se, principalmente, com o monitoramento nociceptivo e proprioceptivo da ATM (DUBNER et al., 1978). Os receptores sensoriais relacionados com essas fibras variam qualitativa e quantitativamente de acordo com a espécie animal analisada. Deste modo, alguns trabalhos descrevem, além de terminações nervosas livres, terminações nervosas encapsuladas na cápsula da ATM de gatos (KAWAMURA et al., 1967), macacos (KELLER e MOFFETT, 1968) e humanos (GRIFFIN e HARRIS, 1975; WINK et al., 1992). Em camundongos e ratos foi constatado, através de análise ao microscópio eletrônico de transmissão, aliada ao transporte axonal anterógrado de neurotraçadores, que esses receptores são exclusivamente terminações nervosas livres (KIDO et al., 1995). Tais receptores sensoriais são provenientes de fibras nervosas pertencentes aos grupos $C$ (fibras amielínicas $\leq 1 \mu \mathrm{m}$ de diâmetro) e Aठ (fibras mielínicas de 1 a $3 \mu \mathrm{m}$ de diâmetro) (KIDO et al., 1995). A análise das características neuroquímicas dessas fibras revelou a presença de inúmeros neuropetídeos. A substância $\mathrm{P}$ (SP) e o peptídeo relacionado ao gene da calcitonina (CGRP) foram detectados pelo método imunoistoquímico em fibras e terminações nervosas na ATM de macacos (JOHANSSON et al., 1986), ovelhas (TAHMASEBI-SARVESTANI et al., 1996; TAHMASEBI-SARVESTANI et al., 1997), ratos (ICHIKAWA et al., 1989; ICHIKAWA et al., 1990; KIDO et al., 1993; SHIMIZU et al., 1996; UDDMAN et al., 1998), e humanos (HAUECHI et al., 1999). 
A inervação nociceptiva da ATM, além da típica função aferente, responsável pelo monitoramento nociceptivo, apresenta também uma efetiva função eferente, devido ao fato de que os receptores sensorias (terminações nervosas livres) mostram uma liberação basal de neuropeptídeos e/ou aminoácidos excitatórios na matriz extracelular (APPELGREEN et al., 1991; BILEVICIUTE et al., 1993; AHMED et al., 1995; ALSTERGREN et al., 1995; LUNDEBERG et al., 1996). A liberação de neuropeptídeos para a matriz extracelular pode ser alterada em determinadas condições patológicas, como por exemplo, na artrite (APPELGREEN et al., 1991; BILEVICIUTE et al., 1993; AHMED et al., 1995; ALSTERGREN et al., 1995; LUNDEBERG et al., 1996).

A ATM também apresenta uma densa inervação autonômica, representada por um grande contingente de fibras simpáticas (ICHIKAWA et al., 1989; SHIMIZU et al., 1996; UDDMAN et al., 1998; ELFVIN et al., 1998; TAHMASEBI-SARVESTANI et al., 1997; HAUECHI et al., 1999; KIDO et al., 2001) e, supostamente uma discreta quantidade de fibras parassimpáticas (KIDO et al., 2001). Nas articulações sinoviais, a inervação simpática está envolvida com a regulação, da vasomotricidade (vasodilatação e vasoconstrição) (IZUMI, 1999), do extravasamento plasmático (GREEN et al., 1993; MIAO et al., 1996) e da atividade funcional de receptores sensoriais (BLUMBERG e JÄNIG, 1983; NAKAMURA e FERREIRA, 1987), ao passo que a inervação parassimpática participa como um co-adjuvante na vasodilatação e sugere-se que medeia uma potente ação anti-inflamatória em algumas condições patológicas (IZUMI, 1999; VAN MAANEN et al., 2009). Com relação a ATM de ratos, foi constatado que, os pericários dos neurônios responsáveis pela inervação simpática, estão alojados principalmente no gânglio cervical superior e, uma discreta quantidade no gânglio estrelado (WIDENFALK e WIBERG, 1990; UDDMAN et al., 1998; CASATTI et al., 1999), enquanto que, os pericários dos neurônios responsáveis pela inervação parassimpática, estão localizados no gânglio ótico (UDDMAN et al., 1998; CASATTI et al., 1999). Atualmente a enzima envolvida na biossíntese de noradrenalina (MOLINOFF e AXELROD, 1971), a tirosina hidroxilase (TH), e os neuromediadores, neuropeptídeo Y (NPY) e peptídeo intestinal vasoativo (VIP) estão sendo utilizados como marcadores de fibras nervosas simpáticas, no caso dos primeiros, e de fibras nervosas parassimpáticas no caso deste último (ICHIKAWA et al., 1989; SHIMIZU et al., 1996; UDDMAN et al., 1998; KIDO et al., 
2001). Assim foi demonstrada a presença de fibras nervosas imunorreativas ao NPY, ao VIP, e à enzima TH na ATM de ratos (ICHIKAWA et al., 1989; SHIMIZU et al., 1996; UDDMAN et al., 1998; KIDO et al., 2001), cobaias (ELFVIN et al., 1998), ovelhas (TAHMASEBI-SARVESTANI et al., 1997) e humanos (HAUECHI et al., 1999). Todavia, o NPY e o VIP não são marcadores exclusivos de fibras nervosas simpáticas e parassimpáticas, respectivamente, sendo assim assumir essa premissa generalista é uma falha relativamente freqüente em alguns trabalhos.

Diante disso, constatamos que a inervação autonômica de articulações sinoviais, além de promover a liberação dos neuromediadores clássicos, como acetilcolina (parassimpático) e noradrenalina (simpático), também libera neuropeptídeos na matriz extracelular, tanto em condições fisiológicas, como patológicas (APPELGREEN et al., 1991; BILEVICIUTE et al., 1993; AHMED et al., 1995; ALSTERGREN et al., 1995; LUNDEBERG et al., 1996), à semelhança do ocorre com as fibras nervosas sensoriais. Em resumo, vários neuromediadores, principalmente neuropeptídeos e amonoácidos excitatórios, foram detectados no fluido sinovial de ATMs humanas e de ratos, bem como concentrações significativamente alteradas, quando tais articulações estão sob vigência de artrite (APPELGREEN et al.,1991; BILEVICIUTE et al., 1993; AHMED et al., 1995; ALSTERGREN et al., 1995; LUNDEBERG et al., 1996). Esses dados sugerem uma estreita correlação entre o suprimento nervoso com a homeostase articular e a patogenia do processo inflamatório articular (LEVINE et al., 1985; LEVINE et al., 1993; KOOP, 1998).

\subsection{Artrite na articulação temporomandibular e seus modelos experimentais}

A reação inflamatória em articulações sinoviais tem patofisiologia semelhante à inflamação que acomete qualquer outro território. Henderson e Edwards (1987) reportaram que, talvez, a única peculiaridade observada no processo inflamatório em articulações sinoviais seja a migração polarizada de leucócitos em direção a cavidade articular. Ademais, observa-se aumento da permeabilidade vascular, migração de células de defesa e, alterações quantitativas e qualitativas na matriz extracelular (HENDERSON e EDWARDS, 1987). 
A fase aguda do processo inflamatório articular, sob o ponto de vista histopatológico, é caracterizada pela presença de um infiltrado inflamatório polimorfonuclear na membrana sinovial, nos ligamentos intra-articulares, na cápsula articular e no líquido sinovial. Nessa fase do processo inflamatório, as alterações ficam basicamente confinadas ao tecido conjuntivo propriamente dito $e$ desencadeiam modificações quantitativas e qualitativas no líquido sinovial (HENDERSON e EDWARDS, 1987). As alterações vasculares da articulação sob vigência de processo inflamatório agudo desencadeiam um aumento na produção de liquido sinovial, assim como, alterações na sua composição bioquímica, sendo constatado modificações na concentração de inúmeros mediadores inflamatórios, tais como prostaglandinas (KIRKER-HEAD et al., 2000; ALSTERGREN e KOOP, 2000), tromboxanos (GRIGNARI et al., 1996), leucotrienos (TSUJl et al., 1999), bradicinina (GUZZO et al., 2000) e, de alguns neuromediadores, tais como neuropeptídeos (APPELGREEN et al., 1991; BILEVICIUTE et al., 1993; AHMED et al., 1995; ALSTERGREN et al., 1995; LUNDEBERG et al., 1996) e, aminoácidos excitatórios (LAWAND et al., 2000, MCNEARNEY et al., 2000). Essas modificações levam ao desencadeamento de sensibilidade dolorosa espontânea, agravada pelo movimento, resultando em uma diminuição consciente dos movimentos articulares.

Segundo Henderson e Edwards (1987) a fase crônica do processo inflamatório em articulações sinoviais é caracterizada pela presença de um infiltrado inflamatório mononuclear, composto fundamentalmente por macrófagos, plasmócitos e linfócitos. O infiltrado inflamatório acomete principalmente a membrana sinovial, os ligamentos intra-articulares e a cápsula articular. A membrana sinovial apresenta-se espessada, principalmente em decorrência da divisão mitótica das células da camada íntima e, da migração de células de defesa para a camada subíntima. Além disso, aumentam as vilosidades da membrana sinovial que se projetam para a cavidade articular. O líquido sinovial permanece com composição alterada e, mostrase extremamente viscoso, principalmente em decorrência da produção aumentada de ácido hialurônico pelas células $A$ ou $F$ da membrana sinovial. Nessa fase há repercussão do processo inflamatório para o tecido ósseo e cartilaginoso, sendo comum a observação de áreas de reabsorção (HENDERSON e EDWARDS, 1987). Um outro aspecto comum as artrites, especificamente aquela que acomete a ATM, é que geralmente após uma fase aguda, a mesma progride para uma fase crônica, 
sendo muito frequentes os episódios de agudização (KAMELCHUK e MAJOR, 1995; DONALDSON, 1995; TANAKA et al., 2008).

Dentre as ferramentas que nos auxiliam compreender a patofisiologia das artropatias inflamatórias e, suas consequências, estão os modelos experimentais de artrite. Geralmente em tais modelos, o processo inflamatório articular é desencadeado pela injeção de agentes inflamatórios no espaço articular. Dentre os modelos clássicos de artrite induzida experimentalmente, estão aquele de artrite aguda desencadeada pela carragenina (CAR) e, um outro de artrite crônica induzida pelo adjuvante de Freund completo (CFA).

A carragenina é um polissacarídeo derivado de algas marinhas (Gigartina aciculaire e Gigartina pistillata), a qual geralmente é diluída em solução salina fisiológica e utilizada em uma concentração que varia de $2 \%$ à 10\% (SCHAIBLE e SCHMIDT, 1985; SCHAIBLE et al., 1990; SCHAIBLE et al., 1994; HANESCH et al., 1997; BILEVICIUTE et al., 1993; BILEVICIUTE et al., 1994; NEUGEBAUER et al., 1995; LUNDEBERG et al., 1996, DAMICO, 1998; ERVOLINO, 2001; DENADAI SOUZA et al., no prelo). Sua injeção intra-articular promove rapidamente uma inflamação aguda asséptica caracterizada pela imediata formação de edema e instalação de intenso infiltrado inflamatório (SCHAIBLE e SCHMIDT, 1985; SCHAIBLE et al., 1990; SCHAIBLE et al., 1994; HANESCH et al., 1997; BILEVICIUTE et al., 1993; BILEVICIUTE et al., 1994; NEUGEBAUER et al., 1995; LUNDEBERG et al., 1996; DAMICO, 1998; ERVOLINO, 2001). O mecanismo de ação da carragenina é um evento extremamente complexo, que envolve uma série de mediadores, tais como, histamina, serotonina, várias cininas, leucotrienos, prostaglandinas (DI ROSA et al., 1968; DI ROSA, 1972; SEDGWICK et al., 1985), além do envolvimento da ciclo-oxigenase induzida (COX-2) (SEIBERT et al., 1994) e do óxido nítrico (SALVEMINI et al., 1996). A inflamação induzida por este agente flogístico atinge seu pico de 4 à 6 horas após sua administração, quando a resposta vascular e a migração celular atingem seus maiores níveis (GARCIA-LEME et al., 1973; SANTER et al., 1983). Nesta fase o infiltrado inflamatório caracteriza-se pela predominância quase que absoluta de polimorfonucleares neutrófilos (DI ROSA, 1972). Com o decorrer do tempo o processo inflamatório tende a cronificação, as características histopatológicas são drasticamente alteradas, havendo um predomínio de células mononucleadas, especialmente macrófagos, cuja quantidade 
vai diminuindo de maneira relativamente rápida até que 0 tecido retorna espontaneamente às suas condições de normalidade (SANTER et al., 1983).

O CFA é um agente artritogênico composto por uma suspensão de micobactéria morta, Mycobacterium tuberculosis ou Mycobacterium butyricum, em óleo de parafina contendo mono-oleato de manitol como surfactante (VAN EDEN et al., 1989; WAUBEN, 1994). O mecanismo que desencadeia a resposta inflamatória articular induzida pelo CFA envolve cada um de seus constituintes. Primeiramente a própria natureza da suspensão oleosa, o óleo de parafina, desencadeia uma ação irritante no tecido articular (WHITEHOUSE e BECK., 1974), o que é comprovado pela intensa inflamação provocada pela injeção de adjuvante de Freund incompleto em articulações sinoviais (BILLIAU e MATTHYS, 2001). Associado a isto, um epítopo contido em uma "heat shock protein" (HSP) de $65 \mathrm{kDa}$ da micobactéria complementa sua ação artritogênica (VAN EDEN et al., 1989). Este epítopo, a sequência de aminoácidos de 180 a 188 da HSP, é reconhecido por linfócitos $T$, os quais por reatividade cruzada, passam a reconhecer um auto-antígeno na cartilagem articular, desencadeando uma reação de hipersensibilidade neste território (VAN EDEN et al., 1989). A injeção de grande quantidade de CFA (entre 500 à $1000 \mu \mathrm{g}$ de Mycobacterium tuberculosis ou Mycobacterium butyricum) na base da cauda, na pata ou em linfonodos promove a forma mais severa de artrite induzida por este agente inflamatório, a poliartrite, a qual apresenta dois estágios bem característicos (WAUBEN, 1994). O primeiro estágio é uma intensa inflamação aguda localizada que se inicia poucas horas após sua inoculação e perdura por aproximadamente 2 dias. Na seqüência desenvolve-se uma reação inflamatória difusa que acomete todas as articulações sinoviais, podendo se extender para outros territórios, como os olhos, as orelhas, a cauda e a genitália. Esta inflamação se mantem como tipicamente crônica por cerca de 4 semanas, sendo que após este período, usualmente, ocorre a remissão espontânea do quadro inflamatório (PEARSON et al., 1956; BILLINGHAM e GORDON, 1976; WAUBEN, 1994). A incidência e a severidade da poliartrite induzida pelo CFA é influenciada por vários fatores, tais como: a resistência do hospedeiro, o sítio de injeção do CFA, a própria composição do adjuvante, dentre outros (WHITEHOUSE et al., 1974).

Um modelo menos severo que o anterior, de inflamação articular crônica, é a monoartrie induzida pelo CFA, no qual apenas uma pequena quantidade de CFA 
(inferior a $100 \mu \mathrm{g}$ de Mycobacterium tuberculosis ou Mycobacterium butyricum) é injetada no espaço articular. Neste caso, a reação inflamatória permanece localizada durante todo seu curso (GRUBB et al., 1991; BUTLER et al., 1992; DONALDSON et al., 1993), o qual é de aproximadamente 4 semanas, tendendo a remissão espontaneamente. Nesta, especialmente nos dois primeiros dias, ocorrem os fenômenos vasculares e exsudativos, e instala-se um moderado infiltrado inflamatório no local, o qual é composto basicamente de neutrófilos e alguns macrófagos. Além disso, ocorre uma hiperplasia bastante precoce da membrana sinovial e a instalação de pequenos focos de tecido de granulação nos tecidos articulares (TERRIER et al., 1985). Após a passagem por uma fase intermediária o processo inflamatório cronifica, geralmente a partir da segunda semama pós inoculação, onde o infiltrado inflamatório é tipicamente crônico, com a presença de uma grande quantidade de linfócitos, além de macrófagos e alguns plasmócitos. A membrana sinovial mostra-se bastante espessada e a quantidade de vilosidades sinoviais aumenta consideravelmente (GRUBB et al., 1991; BUTLER et al., 1992; DONALDSON et al., 1993). Copaert (1987) catalogou inúmeros dados em um estudo comportamental minucioso em ratos, que coloca a artrite induzida pelo CFA como um dos melhores modelos para o estudo da dor crônica.

No que se refere a ATM, os agentes inflamatórios supracitados tem sido frequentemente empregados, especialmente após a publicação dos trabalhos pioneiros que se utilizaram da injeção de carragenina (LUNDEBERG et al., 1996) ou do CFA (ZHOU et al., 1999) para a indução de monoartrite nesta articulação. Como reportado anteriomente, a artrite que acomete a ATM tende a cronificação, todavia ocorrendo frequentemente episódios de agudização do processo inflamatório (KAMELCHUK e MAJOR, 1995; DONALDSON, 1995; TANAKA et al., 2008), o que caracteriza a denominada fase crônica-ativa da artrite, que embora seja uma condição clínica frequente, é raramente estudada e raros são os modelos experimentais que mimetizam tal condição.

\subsection{A dor na articulação temporomandibular e a via trigeminal nociceptiva: um resumo}


A dor é uma experiência extremamente complexa, uma vez que envolve componentes sensoriais discriminativos, cognitivos, emocionais e motivacionais. Esta experiência multidimensional tem uma expressão particular na região orofacial, uma vez que este território, principalmente no homem, apresenta um significado biológico, emocional e psicológico especial. A face representa o local de algumas das dores mais comuns do organismo humano, dentre as quais estão as relacionadas com a ATM e/ou com os músculos da mastigação, que fazem parte das denominadas desordens temporomandibulares (DTMs) (VON KORFF et al., 1988; DWORKIN et al., 1990; CARLSSON e LE RESCHE, 1995, TANAKA et al., 2008).

Como mencionado anteriormente, o gânglio trigeminal abriga a quase totalidade dos neurônios sensoriais primários nociceptivos, que enviam fibras nervosas para a ATM (WIDENFALK e WIBERG, 1990; UDDMAN et al., 1998; YOSHINO et al., 1998; CASATTI et al., 1999). Tais neurônios, do ponto de vista morfológico, são classificados como neurônios pseudounipolares, os quais apresentam um corpo celular esférico de pequeno diâmetro, do qual parte um curto e único prolongamento, que logo se bifurca dando origem a um prolongamento que se dirige para a periferia do organismo e um outro que se direciona ao sistema nervoso central. Tais prolongamentos associados às suas bainhas envoltórias constituem as denominadas fibras nervosas.

As fibras nervosas mielínicas, com diâmetro variável de 1 a $3 \mu \mathrm{m}$ são catalogadas como pertencentes ao grupo $A \delta$, enquanto que as fibras nervosas amielímicas, com diâmetro $\leq 1 \mu \mathrm{m}$ catalogadas como do grupo C. Estas fibras nervosas originam os receptores sensoriais de dor ou nociceptores, os quais, do ponto de vista morfológico, são terminações nervosas livres (MESSLINGER, 1997; PERROT e GUILBAUD, 1996). Levando-se em consideração critérios fisiológicos, os nociceptores vinculados às fibras nervosas do grupo Aठ são denominados de mecanotermonociceptores e são ativados por estímulos mecânicos e térmicos de alta intensidade (MESSLINGER, 1997; PERROT e GUILBAUD, 1996). Enquanto que aqueles vinculados às fibras do grupo $C$ são denominados de mecanotermoquimionociceptores ou polimodais, e são ativados por estímulos mecânicos e térmicos de alta intensidade, assim como por substâncias químicas, principalmente aquelas endógenas que se formam durante a evolução do processo inflamatório (PERROT e GUILBAUD, 1996; MESSLINGER, 1997). Essas 
substâncias congregam o grupo das denominadas algógenas, que estimulam os nociceptores diretamente, do qual faz parte a bradicinina e, aquelas chamadas de potencializadoras da dor, as quais reduzem o limiar de excitabilidade dos receptores de dor, que englobam as prostaglandinas, a histamina, serotonina e cininas. Além disso, inúmeras substâncias produzidas e liberadas pelos próprios neurônios sensoriais primários influenciam a excitabilidade de seus receptores sensoriais (SESSLE, 1999; ROBINSON et al., 2004; SESSLE, 2005; SESSLE, 2006). A esse aumento na responsividade e a redução do limiar de nociceptores à estimulação de seus campos receptivos denominamos de sensibilização periférica (SESSLE, 1999; SESSLE, 2005; SESSLE, 2006).

O outro prolongamento dos neurônios sensorais primários do gânglio trigeminal se projeta centralmente, para o tronco encefálico ipsilateral, onde estabelece conexão sináptica com os neurônios de segunda ordem, essecialmente nos núcleos que compõem o complexo nuclear sensorial trigeminal. Os constituintes deste complexo nuclear incluem, o núcleo sensitivo principal do nervo trigêmeo (P5) e o núcleo do trato espinal do nervo trigêmeo (Sp), o qual é subdividido em: subnúcleo oral (Sp50), subnúcleo interpolar (Sp5I) e subnúcleo caudal (Sp5C). Há um substancial corpo de evidências que apontam o Sp5C como a principal estação sináptica do tronco encefálico relacionada com processamento da informação nociceptiva trigeminal (SESSLE, 1999; BEREITER et al., 2002; BEREITER et al., 2005, SESSLE, 2005; SESSLE, 2006).

O Sp5C se extende do óbex, onde verificamos uma zona de transição entre o Sp5C e o Sp5I, até os segmentos mais rostrais do corno dorsal da medula espinal, onde identificamos a zona de transição do $\mathrm{Sp} 5 \mathrm{C}$ como os segmentos $\mathrm{C} 1$ e $\mathrm{C} 2$. À semelhança do corno dorsal da medula espinal, os neurônios do Sp5C apresentam uma distribuição laminar, são elas: a lâmina marginal (lâmina I), a substância gelatinosa (lâmina II) e a camada magnocelular (lâmina III - IV). A distinção das lâminas no Sp5C se baseia na morfológia apresentada pelos neurônios situados em cada uma delas, os quais apresentam determinadas características neuroquímicas particulares de cada lâmina (PAXINOS, 1995). Do ponto de vista fisiológico, os neurônios nociceptivos localizados neste subnúcleo podem ser categorizados em: neurônios nociceptivos específicos ou neurônios de ampla faixa dinâmica (do inglês, "wide dynamic range" - WDR). Os neurônios de ampla faixa dinâmica recebem 
aferências não apenas de fibras $C$ e $A \delta$, mas também de fibras nervosas mielínicas de maior diâmetro, relacionadas com a transmissão de outros estímulos que não os nociceptivos. Os neurônios nociceptivos específicos recebem aferências exclusivamente de fibras nervosas $C$ a $A \delta$, sendo excitados apenas por estímulos de alta intensidade aplicados em um determinado campo receptivo orofacial. Sendo assim, enquanto o campo receptivo dos neurônios nociceptivos específicos é puramente nociceptivo, e geralmente pequeno, aqueles neurônios de ampla faixa dinâmica apresentam tipicamente extensos campos receptivos e podem ser excitados tanto por estímulos nociceptivos como não-nociceptivos (SESSLE, 2000)

Os neurônios situados no Sp5C tem uma enorme variedade de eferências. Dentre tais eferências estão aquelas intrínsecas, em que o Sp5C estabelece conexões com os outros núcleos sensoriais que compõem o complexo trigeminal situado no tronco encefálico (NASUTION e SHIGENAGA, 1987). No entanto, dentre as projeções de extrema importância para a via trigeminal nociceptiva, estão aquela que os neurônios de segunda ordem, situados no $\mathrm{Sp} 5 \mathrm{C}$, fazem diretamente com os neurônios de terceira ordem situados basicamente no núcleo ventral-póstero-medial do tálamo, via trato trigeminotalâmico. Os neurônios de terceira ordem, cujos axônios de projetam para o córtex sensorial primário, ativarão os neurônios corticais. A percepção dolorosa resultante da ativação dessa via neural é caracterizada por ser de bem localizada, de qualidade bem definida no que se refere a identificação do agente agressor, sendo a dor assim caracterizada denominada de dor aguda (primária) (SESSLE, 1999; SESSLE, 2005; SESSLE, 2006).

Além da ativação da via citada anteriormente, também pode ser acionada uma outra via sensorial paralela, caracterizada pelo fato de que a tranmissão da informação nociceptiva do Sp5C o tálamo não se faz como uma linha direta, mas interrompida pelo estabelecimento de várias conexões sinápticas com um razoável número de neurônios, especialmente da formação reticular. Esses neurônios da formação reticular também recebem inúmeras outras informações sensoriais, tais como, tátil, pressora, térmica, auditiva, etc. Os útimos neurônios desta via polissináptica enviam axônios para os chamados núcleos intralaminares do tálamo, cujos neurônios apresentam projeções difusas para o córtex cerebral. A percepção dolorosa resultante da ativação dessa via neural é caracterizada por ser de menor intensidade, difusa e de maior tempo de duração, sendo que a dor assim 
caracterizada denominada de dor crônica (secundária) (SESSLE, 1999; SESSLE, 2005; SESSLE, 2006).

Salientamos ainda que os mecanotermonociceptores originados de fibras nervosas mielínicas do grupo $A \delta \bar{\delta}$ acionam fundamentalmente a via neural direta, condicionantes da dor primária ou aguda. Já os mecanotermoquimionociceptores, originados das fibras nervosas amielínicas do grupo $\mathrm{C}$, acionam a via neural indireta condicionante da dor secundária ou crônica (SESSLE, 1999; SESSLE, 2005; SESSLE, 2006).

A transmissão nociceptiva pode ser modulada tanto em nível talâmico como cortical, no entanto muitas das modificações da mensagem ascendente ocorre especificamente no Sp5C. A informação nociceptiva que atinge o Sp5C está sujeita a modulação efetuada por neurônios que constituem o sistema endógeno de modulação da dor (BASBAUM e FIELDS, 1984; CARTENS, 1987; FIELDS e BASBAUM, 1989; GEBHART e RANDICH, 1990; JONES, 1992). O circuito neural composto pela substância cinzenta periaqueductal- (PAG)- área rostral ventromedial da medula oblonga (RVM)- Sp5C é uma parte do sistema endógeno de modulação da dor relativamente bem caracterizada (GEBHART, 1986; FIELDS et al., 1991; FIELDS e BASBAUM, 1999; MILLAN, 2002). A PAG envia fibras nervosas inibitórias diretamente para o Sp5C (MORGAN et al., 1997), ou indiretamente usando a RVM como uma estação intermediária (MORGAN et al., 1997, BEITZ et al.,1983). Os neurônios da RVM também podem emitir fibras nervosas para o Sp5C diretamente ou via neurônios localizados no locus coeruleus (LC) (KLATT et al., 1988; LI et al., 1993; TERHORST et al., 2001). Além disso, nas últimas décadas alguns trabalhos apontam outros territórios do tronco encefálico como atuantes na modulação da resposta nociceptiva e, os incorpora ao sistema endógeno de modulação da dor (JANSS e GEBHART, 1988; JONES, 1992; TAVARES e LIMA, 1994; SUN e PANNETON, 2002; TAVARES e LIMA, 2002), são eles: o núcleo do trato solitário (NTS), a área caudal ventrolateral da medula oblonga (CVLM) e o núcleo reticular ventral (NRV), os quais tem sido apontados como fundamental nesta modulação e, como especulam alguns autores com atuação até mais significativa que a RVM e a PAG (TAVARES e LIMA, 1994; JANSS e GEBHART, 1988; SUN e PANNETON, 2002; TAVARES e LIMA, 2002). 


\section{CAPÍTULOS}




\section{CAPÍTULO 1}

Caracterização neuroquímica e ultra-estrutural das fibras e terminações nervosas autonômicas da articulação temporomandibular do rato 


\subsection{INTRODUÇÃO}

Dentre as artropatias que acometem as articulações sinoviais estão, como uma das mais comuns, as artrites (HOOTMAN e HELMICK, 2006; CENTERS FOR DISEASE CONTROL AND PREVENTION, 2006). Uma intrigante característica clínica apresentada por algumas modalidades de artrite, é que a magnitude do processo inflamatório articular é substancialmente influenciada pela localização da articulação, ou seja, as articulações distais desenvolvem um quadro inflamatório muito mais severo do que as articulações proximais (MITCHENS e FRIES, 1982). Diante disso, especialmente nas duas últimas décadas, desencadeou-se uma busca aos possíveis fatores que pudessem explicar o comportamento diferencial assumido por tais articulações. Neste período alguns estudiosos atentaram para o fato de que, as articulações distais mostram-se mais densamente inervadas em relação às proximais (MITCHENS e FRIES, 1982). Desde então, considerável importância tem sido atribuída à participação do sistema nervoso tanto na homeostase articular quanto na patofisiologia das artrites.

O complexo articular temporomandibular (CATM) é composto por duas articulações sinoviais, que embora não sejam um exemplo típico de articulação de localização distal, apresentam uma densa inervação sensitiva e autonômica (ICHIKAWA et al., 1989; KIDO et al., 1993; SHIMIZU et al., 1996; UDDMAM et al., 1998; KIDO et al., 2001).

A inervação sensorial nociceptiva da articulação temporomandibular (ATM) do rato é basicamente representada por terminações nervosas livres, originadas de fibras nervosas amielínicas do tipo C e mielínicas do tipo Aঠ (KIDO et al., 1995). Tais fibras nervosas são provenientes de neurônios sensoriais primários, cujos corpos celulares, estão alojados predominantemente no gânglio trigeminal (WIDENFALK e WIBERG, 1990; UDDMAN et al., 1998; YOSHINO et al., 1998; CASATTI et al., 1999). Tais neurônios apresentam imunorreatividade à vários neuropeptídeos, tais como substância P (SP), peptídeo relacionado ao gene da calcitonina (CGRP), somatostatina (SOM) e, a alguns aminoácidos excitatórios, como o glutamato (ICHIKAWA et al., 1989; KIDO et al., 1993; SHIMIZU et al., 1996; UDDMAN et al., 1998), ou seja, neuromediadores classicamente envolvidos com o processamento da informação nociceptiva (MCCARTHY e LAWSON, 1989; LAWSON et al., 1993; 
HOHEISEL et al., 1994; LAWSON et al., 1997). Alguns trabalhos descreveram minuciosamente a distribuição das fibras nervosas sensitivas na cápsula articular, nos ligamentos intra-articulares, na periferia do disco articular e na membrana sinovial da ATM do rato (KIDO et al., 1991 ; KIDO et al., 1993; KIDO et al., 1995). Do ponto vista funcional, a inervação sensorial nociceptiva de uma articulação sinovial como a ATM, além da típica função aferente, apresenta uma efetiva função eferente, a qual consiste na liberação de neuromediadores, mediadores do processo inflamatório e fatores de crescimento nos tecidos articulares (HOLZER, 1998). A detecção de inúmeros neuropeptídeos nos tecidos articulares e, diluídos no líquido sinovial de articulações de ratos e humanos, é um forte indício de que a função eferente dos neurônios sensoriais primários seja importante para a homeostase articular (APPELGREEN et al., 1991; BILEVICIUTE et al., 1993; AHMED et al., 1995; ALSTERGREN et al., 1995; LUNDEBERG et al., 1996). Além disso, inúmeros trabalhos constataram alterações significativas na concentração de vários neuromediadores na ATM durante a vigência de artrite, tanto em animais quanto em humanos (APPELGREEN et al., 1991; BILEVICIUTE et al., 1993; AHMED et al., 1995; ALSTERGREN et al., 1995; LUNDEBERG et al., 1996), sugerindo um envolvimento de tais substâncias, secretados pelos receptores sensoriais, com a patofisiologia da artrite (LEVINE et al., 1985; LEVINE et al., 1993; KOOP et al., 1998; VILENSKY e COOK, 1998).

No que se refere a inervação autonômica das articulações sinoviais, por muito tempo foi pouco explorada, no entanto, a partir do momento em que alguns estudos demostraram a relação entre sistema nervoso simpático e a nocicepção (WIESENFELD-HALLIN e HALLIN, 1984; JÄNIG e KOLLMANN, 1984; DUARTE et al., 1988; ABELLI et al., 1993; RODRIGUES et al., 2006) e, o envolvimento de alguns neuromediadores, tipicamente sintetizados por neurônios ganglionares autonômicos, com a inflamação (BASBAUM e LEVINE, 1993; GREEN et al., 1993; ALSTERGREN et al., 1999; ZUKOWSKA et al., 2003; MILLER et al., 2005), trabalhos começaram a explorar os aspectos morfológicos e funcionais desta inervação em articulações sinoviais. Na ATM do rato, alguns autores constataram uma considerável quantidade de fibras e terminações nervosas imunorreativas a tirosina hidroxilase (TH) (ICHIKAWA et al., 1989; SHIMIZU et al., 1996; UDDMAN et al., 1998), enzima chave na biossíntese de noradrenalina (MOLINOFF e AXELROD, 
1971), e ao neuropeptídeo Y (NPY) (ICHIKAWA et al., 1989; SHIMIZU et al., 1996; UDDMAN et al., 1998), um neuromediador encontrado predominantemente em fibras nervosas simpáticas, contudo não sendo um marcador exclusivo deste tipo de fibra nervosa. Estas fibras e terminações nervosas estavam localizadas principalmente na circunjacência de vasos sanguíneos situados na cápsula articular e nos ligamento intra-articulares (ICHIKAWA et al., 1989; SHIMIZU et al., 1996; UDDMAN et al., 1998). As fibras nervosas simpáticas que inervam a ATM são proveniente de corpos celulares alojados nos gânglios cervical superior e estrelado (WIDENFALK e WIBERG, 1990; UDDMAN et al., 1998; CASATTI et al., 1999). Quanto à função da inervação autonômica simpática em articulações sinoviais, vários trabalhos demonstraram uma efetiva participação na regulação da vasomotricidade (GREEN et al., 1993; MIAO et al., 1996), uma interferência significativa no extravasamento plasmático no ambiente articular durante a inflamação (GREEN, et al. 1993; MIAO et al., 1996) e um papel modulatório na atividade funcional de receptores sensoriais (BLUMBERG e JÄNIG, 1983; NAKAMURA e FERREIRA, 1987).

Raros são os estudos existentes na literatura científica que abordaram a inervação autonômica parassimpática da ATM, inclusive a sua presença em articulações sinoviais foi por muito tempo questionada. Utilizando-se da deposição de traçador neuronal retrógrado na ATM do rato, Casatti et al. (1999), reportaram que os neurônios responsáveis pela inervação autonômica parassimpática desta articulação estão alojados no gânglio ótico. Isto faz da ATM uma das poucas articulações sinoviais que possui a inervação parassimpática alocada em um gânglio nervoso com identidade anatômica definida. Quanto à função desempenhada pela inervação parassimpática nas articulações sinoviais a regulação da vasomotricidade e a liberação de neuropeptídeos com potente ação anti-inflamatória foram as descritas até o presente momento (IZUMI, 1999; VAN MAANEN et al., 2009).

Diante do exposto, verificamos que a inervação sensorial nociceptiva da ATM não está envolvida apenas com o monitoramento sensorial, e que a inervação autonômica não atua apenas no controle do tônus vascular. Inúmeros trabalhos têm adicionado novas informações sobre a atuação do sistema nervoso nas articulações sinoviais, tais como: função eferente dos neurônios sensoriais primários (HOLZER, 1998; DONALDSON, 1999); inervação simpática diferencial em determinados segmentos dos vasos sanguíneos (MIAO et al., 1996); interações funcionais entre 
inervação sensorial e autonômica (BLUMBERG e JÄNIG, 1983; NAKAMURA e FERREIRA, 1987); presença de inervação simpática na membrana sinovial não relacionadas com elementos vasculares (SHIMIZU et al., 1996; HAEUCHI et al., 1999); além de uma suposta participação como mediador dos efeitos contralaterais das monoartrites (BILEVICIUTE et al., 1993; BILEVICIUTE et al., 1994; KIDD et al., 1995; DONALDSON et al., 1999). Atualmente um crescente número de trabalhos explora os aspectos funcionais relacionados com a inervação autonômica da ATM, no entanto, alguns aspectos neuroquímicos e estruturais acerca desta inervação são incompletos e, a análise morfológica da inervação autonômica da ATM é essencial para complementação de dados advindos de estudos fisiológicos, patofisiológicos e farmacológicos. O único estudo encontrado na literatura que fez uma análise mais detalhada da inervação autonômica da ATM se utilizou de uma metodologia imprecisa em alguns aspectos, ou seja, empregou a imunomarcação de alguns neuropeptídeos, que não são exclusivos de fibras nervosas simpáticas ou parassimpáticas, para descrever tal inervação, isso tornou algumas de suas conclusões falhas (KIDO et al., 2001). Diante do exposto, o propósito do presente estudo foi analisar a distribuição simultânea de alguns marcadores tidos como clássicos de neurônios simpáticos e parassimpáticos, TH, NPY e VIP, pelo método da imunofluorescência, em ATMs que apresentavam as seguintes condições: inervação intacta; desprovidas de inervação simpática; desprovidas de inervação parassimpática ou; desprovidas tanto de inervação simpática quanto de parassimpática. Além disso, um outro intuito deste trabalho foi realizar um estudo topográfico ultra-estrutural das fibras e terminações nervosas autonômicas na ATM do rato, as quais foram demonstradas aliando-se o tratamento prévio com 5hidroxidopamina (5-OHDA), para evidenciação de fibras e terminações nervosas simpáticas, com a remoção cirúrgica do gânglio ótico, o que permitiu a visualização das fibras e terminações nervosas parassimpáticas em degeneração. 


\subsection{MATERIAL E MÉTODO}

Neste experimento foram utilizados 17 ratos machos (Rattus novergicus) da linhagem Wistar, adultos jovens, com 280 - $300 \mathrm{~g}$ de peso corporal, obtidos no Biotério Central de Criação da Faculdade de Odontologia de Araçatuba da Universidade Estadual Paulista (FOA - UNESP). Os animais foram mantidos no Biotério de Experimentação da disciplina de Histologia e Embriologia da FOAUNESP sob as seguintes condições: ciclo de 12 horas de claro e 12 horas de escuro, temperatura ambiente de $22 \pm 2{ }^{\circ} \mathrm{C}$, sistema de ventilação/exaustão permitindo 20 trocas de ar por hora, umidade relativa do ar em torno de $55 \pm 5 \%$, acondicionamento em gaiolas plásticas (3 animais por gaiola), onde os animais tinham livre acesso ao alimento e a água. Foram tomadas todas as medidas cabíveis para se minimizar o número de animais utilizados, assim como evitar o seu sofrimento. Os procedimentos de manipulação experimental dos animais foram realizados de acordo com as normas estabelecidas no "Colégio Brasileiro de Experimentação Animal" (COBEA), e o protocolo experimental foi aprovado pela Comissão de Ética na Experimentação Animal da FOA - UNESP (certificado em anexo).

\subsubsection{Anestesia}

Para a execução dos procedimentos cirúrgicos os animais foram anestesiados, via injeção intramuscular, de cloridrato de cetamina $(100 \mathrm{mg} / \mathrm{Kg}$, Francotar $\AA$, Virbac, SP, Brasil) e cloridrato de xilazina (14 mg/kg, Rompum ${ }$, Bayer, RS, Brasil).

\subsubsection{Delineamento experimental 1: Caracterização neuroquímica das fibras e terminações nervosas autonômicas na ATM}

\section{Grupos controle e experimentais}


Os animais $(n=12)$ foram divididos em 4 grupos, cada um composto de 3 animais, número rotineiramente utilizado em trabalhos de natureza descritiva (Fig. 5):

grupo ATM inervação intacta (SP): cujos animais apresentavam a inervação sensorial e a autonômica da ATM intactas.

- grupo ATM desprovida de inervação simpática (XP): cujos animais foram submetidos a remoção cirúrgica do gânglio cervical superior esquerdo e, 7 dias depois foram submetidos a eutanásia. Para a ganglionectomia, foi realizada uma incisão parasagital na pele da região infra-hioídea, de aproximadamente de $10 \mathrm{~mm}$ de extensão, incluindo também o músculo platisma, com a finalidade de se obter acesso à glândula submandibular, a qual foi dissecada e rebatida, mantendo-se contudo a integridade de seu pedículo vásculo-nervoso. Posteriormente a esta manobra obtínhamos o acesso à confluência dos músculos esternohioídeo, omohioídeo e esternocleideomastoídeo. Com auxílio de um microscópio estereoscópio cirúrgico (MCM5 - D. F. Vasconcellos S/A) os músculos foram parcialmente afastados até a visualização da bifurcação da artéria carótida comum. Esta foi tracionada lateralmente, com auxílio de pinça fixada a sua túnica adventícia. A partir de sua exposição, o gânglio cervical superior foi removido através de manobra de divulsão do tecido conjuntivo adjacente e, secção do tronco simpático e seus ramos comunicantes. Posteriormente, os músculos e a glândula submandibular foram reposicionados e a pele suturada com pontos interrompidos. Em todos os animais simpatectomizados foi possível observar-se sinais típicos da síndrome de Horner, tais como ptose palpebral e miose ipsilaterais. Como tal gânglio abriga os neurônios ganglionares simpáticos que enviam fibras pós-ganglionares simpáticas para a ATM esquerda, esta articulação, ao final do período experimental se mostrava desprovida de inervação autonômica simpática.

- grupo ATM desprovida de inervação parassimpática (SX): cujos animais foram submetidos à remoção cirúrgica do gânglio ótico do lado esquerdo e, 7 dias depois submetidos a eutanásia. Para a ganglionectomia, foi realizada uma incisão na pele de aproximadamente $7 \mathrm{~mm}$ de extensão, medialmente ao corpo da mandíbula e seguindo seu contorno. Em prosseguimento, foi realizada a dissecção da porção 
medial do músculo pterigoídeo medial até nos aproximarmos de sua origem no osso esfenóide. Neste ponto, esse músculo foi divulsionado até a exposição do território onde trafegava a artéria pterigopalatina. Utilizando-se de um microscópio estereoscópio cirúrgico esta artéria foi tracionada lateralmente, com auxílio de pinça fixada a sua túnica adventícia. A partir de sua exposição, o gânglio ótico foi removido através de manobra de divulsão do tecido conjuntivo adjacente e secção de seus ramos nervosos. Posteriormente, os planos musculares profundos e superficias foram reposicionados e a pele suturada com pontos interrompidos. Como tal gânglio abriga os neurônios ganglionares parassimpáticos que enviam fibras pósganglionares parassimpáticas para a ATM esquerda, esta articulação, ao final do período experimental se mostrava desprovida de inervação autonômica parassimpática.

- grupo ATM desprovida de inervação simpática e parassimpática (XX): cujos animais foram submetidos a remoção cirúrgica dos gânglios cervical superior e ótico, ambos do lado esquerdo e, 7 dias depois foram submetidos a eutanásia. Sendo assim, ao final do período experimental a ATM esquerda se mostrava desprovida de inervação autonômica simpática e parassimpática.

\section{Eutanásia}

Findado o delineamento dos grupos controle e experimentais, os animais foram devidamente anestesiados, como descrito anteriormente e, submetidos a perfusão transcardíaca com solução salina $0,9 \%$ heparinizada $(100 \mathrm{ml})$, seguida de solução fixadora (800 ml) constituída de $4 \%$ de formaldeído (Sigma, Saint Louis, MO, USA) em tampão tetraborato de sódio 3,8\% (Sigma, Saint Louis, MO, USA), 0,1 M, $4{ }^{\circ} \mathrm{C}, \mathrm{pH}$ 9,5. As ATMs foram cuidadosamente removidas e, com auxílio de um microscópio estereoscópio cirúrgico, realizamos a separação dos tecidos moles que entram na composição da ATM. Tais tecidos foram removidos em monobloco e incluíam o disco articular em associação com os ligamentos intra-articulares e a cápsula articular. Completada a dissecção tais amostras foram submetidas a pósfixação e a crioproteção simultaneamente, na mesma solução fixadora, acrescida de $30 \%$ de sacarose, durante 24 horas. 
GRUPO SP

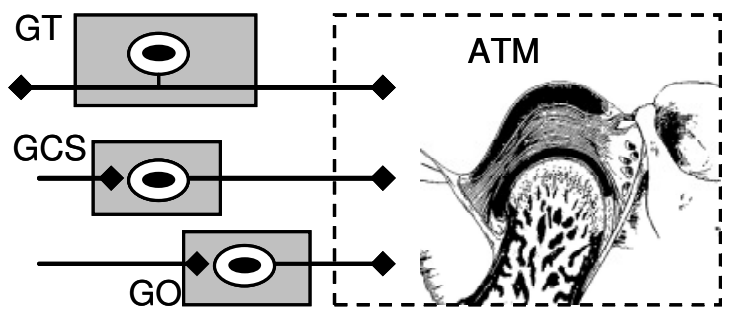

GRUPO SX

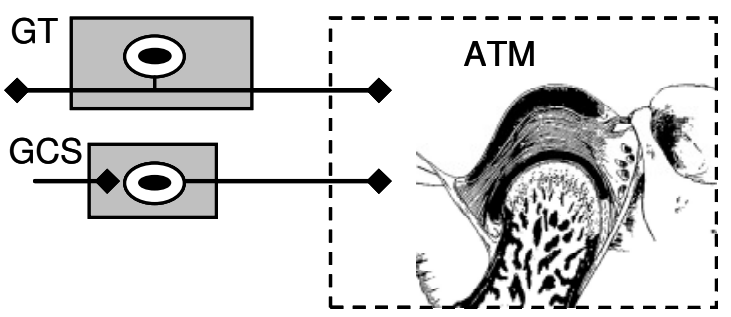

GRUPO XP

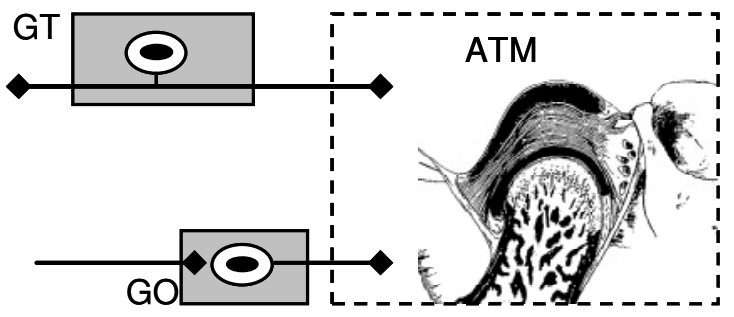

GRUPO XX

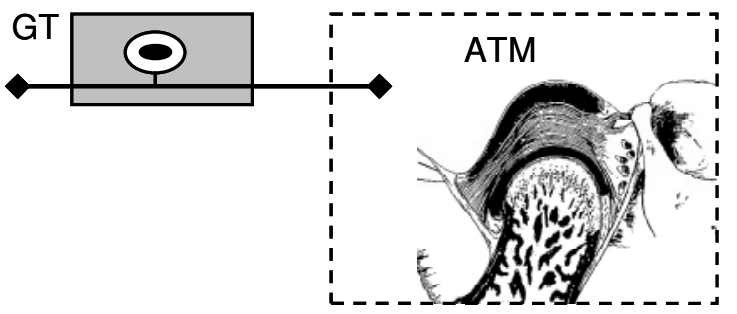

Figura 5. Esquema resumindo o delineamento experimental descrito em 1.2.2. Abreviações: GRUPO SP (inervação autonômica simpática e parassimpática da ATM intactas); GRUPO XP (ATM desprovida de inervação autonômica simpática e inervação parassimpática intacta); GRUPO SX (ATM desprovida de inervação autonômica parassimpática e inervação simpática intacta); GRUPO XX (ATM desprovida tanto de inervação autonômica simpática quanto de parassimpática); GT, gânglio trigeminal; GCS, gânglio cervical superior; GO, gânglio ótico; ATM, articulação temporomandibular.

\section{Preparação das amostras e reação de imunofluorescência para detecção simultânea de TH, NPY e VIP}

Encerrado o período de pós-fixação e crioproteção, as amostras foram seccionadas sagitalmente em micrótomo de congelação (Jung SM2000R, Leica, Nussloch, Alemanha), com $30 \mu \mathrm{m}$ de espessura, sendo que uma, em cada cada seis secções, foi imediatamente coletada em lâmina de vidro gelatinizada para posterior submissão à técnica de imunofluorescência.

As secções das amostras, devidamente fixas as lâminas histológicas, foram submetidos às seguintes etapas, sob agitação constante a $4{ }^{\circ} \mathrm{C}$ : duas lavagens de 10 minutos em solução de tampão fosfato de potássio - KPBS (Sigma, Saint Louis, MO, USA) $0,1 \mathrm{M}, \mathrm{pH} 7,4$; bloqueio de sítios inespecíficos em solução contendo KPBS, $0,15 \%$ de Triton X-100 e 5\% de soro normal de burro (Vector Laboratories, 
Burlingame, CA, USA), durante 3 horas; incubação, durante 24 horas, nos seguintes anticorpos primários: anti-TH de rato gerado em ovelha (1:1000, Calbiochem, USA), anti-VIP de rato gerado em cobaia (1:200, Peninsula Laboratories - USA) e anti-NPY de rato gerado em coelho (1:500, Chemicom International, USA); duas lavagens de 10 minutos em KPBS; incubação, durante 1 hora, nos seguintes anticorpos secundários: anti-IgG de cobaia gerado em burro conjugado com Cy ${ }^{3}$, (1:200, Jackson ImmunoResearch, USA), anti-IgG de coelho gerado em burro conjugado com 7-amino 4-metil coumarin 3-ácido acético (AMCA) (1:100, Jackson ImmunoResearch, USA) e anti-lgG de ovelha biotinilado gerado em burro (1:100, Jackson ImmunoResearch, USA); duas lavagens de 10 minutos em KPBS; incubação, por 1 hora, em solução contendo KPBS, 0,15\% de Triton X-100 e estreptavidina conjugada com diclorotriazinolamino fluoresceína (DTAF) (1:200, Jackson ImmunoResearch, USA); duas lavagens de 10 minutos em KPBS. Os anticorpos foram diluídos em solução contendo KPBS, 0,15\% de Triton X-100, 2\% de soro normal de burro. Finalmente, os cortes histológicos foram desidratados à temperatura ambiente e protegidos com meio de montagem à base de glicerol e lamínulas de vidro.

\section{Análise das amostras e critérios de amostragem}

As preparações histológicas foram observadas em microscópio de epifluorescência (Optiphot-2, NIKON, Japão), com fonte de mercúrio de alta pressão (HB101001 AF-NIKON), ajustado com conjunto de filtros específicos para visualização dos fluorocromos $\mathrm{Cy}^{3}$, AMCA e DTAF. Em toda a extensão dos cortes histológicos submetidos a imunomarcação, foi analisada a presença simultânea de fibras nervosas TH- imunorreativas (TH-IR), NPY-imunorreativas (NPY-IR) e VIPimunorreativas (VIP-IR).

1.2.3 Delineamento experimental 2: Análise topográfica ultra-estrutural das fibras e terminações nervosas autonômicas na ATM

\section{Manipulacão experimental dos animais}


Um único grupo de animais ( $\mathrm{n}=5)$, após ser devidamente anestesiado, como descrito acima, foi submetido à remoção cirúrgica do gânglio ótico, 24 horas antes de serem submetidos a eutanásia. Tais animais também foram submetidos a um tratamento farmacológico, no qual receberam, via intra-peritoneal, três injeções de 3 , 4, 5 tri-hidroxi-fenil-etilamina, também denominda de 5 -hidroxidopamina (33 mg/kg, Sigma, Saint Louis, MO, USA) em associação com ácido ascórbico $(10 \mathrm{mg} / \mathrm{Kg}$, Sigma, Saint Louis, MO, USA), as quais foram administradas no perídodo que precedeu a eutanásia em $3 \mathrm{~h}$, $2 \mathrm{~h}$ e $1 \mathrm{~h}$ (Fig. 6) 


\section{Eutanásia}

Findada a manipulação experimental dos animais, estes foram devidamente anestesiados, como descrito anteriormente e, submetidos a perfusão transcardíaca com solução salina $0,9 \%$ heparinizada $(100 \mathrm{ml}$ ), seguida de solução fixadora (400 $\mathrm{ml}$ ) constituída de $4 \%$ de formaldeído (Sigma, Saint Louis, MO, USA) e 2,5\% de glutaraldeído (Sigma, Saint Louis, MO, USA), em tampão fostato de sódio (Sigma, Saint Louis, MO, USA), 0,1 M, $4{ }^{\circ} \mathrm{C}, \mathrm{pH} 7,4$. Posteriormente as ATMs foram cuidadosamente removidas e, com auxílio de um microscópio estereoscópio cirúrgico, realizamos a separação dos tecidos moles que entram na composição da ATM. Tais tecidos foram removidos em monobloco e incluíam o disco articular em associação com os ligamentos intrínsecos e a cápsula articular. Completada a dissecção tais amostras foram submetidas a uma primeira pós-fixação, na mesma solução fixadora utilizada na perfusão transcardíaca, por 5 horas.

\section{Preparação dos espécimes para estudo ultra-estrutural}

As amostras foram reduzidas a pequenos fragmentos e procedeu-se a uma segunda pós-fixação, em solução contendo 1\% de tetróxido de ósmio (Sigma, Saint Louis, MO, USA) em tampão fosfato de sódio, $0,1 \mathrm{M}, 4{ }^{\circ} \mathrm{C}, \mathrm{pH} 7,4$, durante 2 horas. $\mathrm{Na}$ seqüência as amostras foram desidratadas em soluções crescentes de acetona, infiltradas e incluídas em resina Spurr (SEM - USA). Submeteu-se as amostras a microtomia e os cortes semifinos, de $1 \mu \mathrm{m}$ de espessura, foram corados com azul de toluidina e analisados em microscópio óptico, o que permitiu a seleção das áreas a serem submetidas a ultra-microtomia. Finalmente, os cortes ultra-finos, com aproximadamente $70 \mathrm{~nm}$ de espessura, foram contrastados com acetato de uranila e citrato de chumbo.

\section{Análise das amostras e critérios de amostragem}

As preparações histológicas foram observadas em microscópio eletrônico de transmissão (JEM 100C II, JEOL). A análise ultra-estrutural ficou confinada a região anterior e posterior da zona de transição entre a periferia do disco articular e os 
ligamentos intra-articulares, território densamente inervado por fibras nervosas sensoriais e autonômicas, no qual tínhamos acesso a grande extensão da membrana sinovial e a uma densa vasculatura. Os campos de interesse foram fotografados em filme fotográfico para microcópio eletrônico (Electron microcopy film 4485 - Kodak) e ampliados em papel fotográfico (Policontraste III RC, Kodak). 


\subsection{RESULTADOS}

\subsubsection{Caracterização neuroquímica das fibras e terminações nervosas autonômicas que inervam a ATM do rato}

O emprego da técnica de imunofluorescência indireta, utilizando-se de três anticorpos espécie-específicos simultaneamente, anti-TH, anti-NPY e anti-VIP, mostrou-se eficiente para a identificação de fibras e terminações nervosas localizadas nos seguintes territórios da ATM do rato: cápsula articular, ligamentos intra-articulares, periferia do disco articular e membrana sinovial (Fig. 7 e 8).

Com a metodologia empregada no presente estudo, as fibras e terminações nervosas na ATM apresentaram os seguintes padrões de imunorreatividade: simultaneamente imunorreativas à TH, NPY e VIP (TH/NPY/VIP-IR) (Fig. 7); simultaneamente imunorreativas à TH e ao NPY (TH/NPY-IR) (Fig. 8 A - B); exclusivamente imunorreativas ao VIP (VIP-IR) (Fig. 8 C) e; exclusivamente imunorreativas à $\mathrm{TH}(\mathrm{TH}-\mathrm{IR})$.

Nos animais do grupo SP, cujas ATMs apresentavam a inervação sensitiva e autonômica intactas, a maioria das fibras e terminações nervosas se mostraram TH/NPY/VIP-IR e TH/NPY-IR, as quais estavam situadas em espessos feixes nervosos localizados na cápsula articular e, predominantemente em delgados grupamentos de fibras nervosas nas circunjacências de vasos sanguíneos situados na cápsula articular, nos ligamentos intra-articulares, na periferia do disco articular (Fig. 7) e na membrana sinovial. Nesta última constatamos ainda a presença de algumas poucas fibras exclusivamente VIP-IR, as quais também estavam presentes associadas à vasos sanguíneos mais calibrosos localizados na cápsula articular. Algumas raras fibras exclusivamente TH-IR estavam distribuídas pelos territórios mencionados anteriormente. As camadas íntima e subíntima da membrana sinovial foram os territórios onde constatamos uma quantidade considerável de fibras e terminações nervosas TH/NPY/VIP-IR, TH/NPY-IR (Fig. 8 A - B) e VIP-IR isoladas, ou seja, sem manterem evidente relação com elementos vasculares.

Nos animais do grupo XP, cujas ATMs se mostravam desprovidas de inervação autonômica simpática e com a inervação autonômica parassimpática intacta, constatamos ausência total de fibras e terminações nervosas TH/NPY/VIP- 
IR, TH/NPY-IR e exclusivamente TH-IR, permanecendo somente fibras e terminações nervosas exclusivamente VIP-IR associadas a vasos sanguíneos situados na cápsula articular, nos ligamentos intra-articulares, na periferia do disco articular e na membrana sinovial, sendo que nesta última ainda constatamos a presença de algumas fibras nervosas vipérgicas isoladas no tecido conjuntivo.

Nos animais do grupo SX, cujas ATMs se mostravam desprovidas de inervação autonômica parassimpática e com a inervação autonômica simpática intacta, observamos fibras e terminações nervosos TH/NPY/VIP-IR, TH/NPY-IR e exclusivamente $\mathrm{TH}$-IR em todos os territórios citados anteriormente nos animais do grupo SP, todavia as fibras e terminações nervosas exclusivamente VIP-IR praticamente desapareceram em todos os elementos articulares, exceto aquelas associadas aos vasos sanguíneos mais calibrosos localizados na cápsula articular.

Nos animais do grupo XX, cujas ATMs se mostravam desprovidas de inervação autonômica simpática e parassimpática, constatamos apenas a presença de fibras e terminações nervosas exclusivamente VIP-IR associadas aos vasos sanguíneos mais calibrosos situados na cápsula articular.

Diante dos resultados obtidos constatamos que as fibras nervosas autonômicas simpáticas que inervam a ATM do rato podem se mostrar TH/NPY/VIPIR, TH/NPY-IR e exclusivamente TH-IR, ao passo que as fibras nervosas autonômicas parassimpáticas se mostram imunorreativas apenas ao VIP. Todavia as fibras nervosas exclusivamente vipérgicas presentes na ATM do rato não são exclusivamente parassimpáticas, podendo se tratar de fibras e terminações nervosas sensoriais, provavelmente provenientes de neurônios sensoriais primários do gânglio trigeminal, uma vez que a inervação sensitiva foi preservada em todos os grupos experimentais e, o gânglio nervoso mencionado abrigar a quase totalidade dos neurônios sensoriais que inervam a ATM do rato. Nossos achados estão resumidos na Tabela 1.

\subsubsection{Análise topográfica ultra-estrutural das fibras e terminações nervosas autonômicas na ATM do rato}

A associação entre a remoção cirúrgica do gânglio ótico e o tratamento farmacológico com 5-OHDA, permitiram a identificação de fibras e terminações 
nervosas em processo de degeneração (fibras autonômicas parassimpáticas) e, outras dotadas de uma grande quantidade vesículas elétron-densas, indicativo da incorporação da 5-OHDA (fibras nervosas autonômicas simpáticas), o que confirmou o sucesso da associação das técnicas utilizadas neste estudo (Fig. 9). A análise topográfica ultra-estrutural de fibras e terminações nervosas, nas condições citadas acima, confirmaram a presença destes elementos associados à vasculatura da cápsula articular, dos ligamentos intra-articulares, da periferia do disco articular e da membrana sinovial, sendo possível encontrar algumas varicosidades simpáticas isoladas, especialmente na camada subíntima da membrana sinovial.

As varicosidades simpáticas apresentavam um diâmetro que variando de 0,5 a 1,5 $\mu \mathrm{m}$ e suas inúmeras vesículas apresentavam uma dimensão que variava de 10 a 150 nm de diâmetro (Fig. 9 C - D). Estas vesículas apresentavam um conteúdo elétron-denso ocupando toda a superfície de corte (vesículas tipo I, segundo Chiba, 1972), ou localizado apenas em um de seus pólos (vesícula tipo II, segundo Chiba, 1972). As varicosidades simpáticas estavam presentes em uma quantidade considerável na cápsula articular, nos ligamentos intra-articulares e na porção periférica do disco articular, onde se mostravam a uma distância de pelo menos 1 $\mu \mathrm{m}$ das células musculares dos vasos sanguíneos destes territórios. Na membrana sinovial, especialmente na camada subíntima, observamos a presença de varicosidades simpáticas associadas à vasos sanguíneos e isoladas no tecido conjuntivo, ou seja, aparentemente sem relação com elementos vasculares. $\mathrm{Na}$ camada íntima da membrana sinovial houve grande dificuldade de se discernir com segurança tais varicosidades entre as células $M$ (células fagocitárias) e $F$ (células com intensa atividade de síntese de proteínas de exportação), uma vez que algumas extensões citoplasmáticas das células $F$ acumulam vesículas elétron-densas com as características ultra-estruturais citadas acima.

As fibras e terminações nervosas parassimpáticas, com um diâmetro variando de 0,5 a $1 \mu \mathrm{m}$, foram identificadas pela presença de uma intensa elétron-densidade preenchendo todo o volume citoplasmático ou, pela presença de corpos multivesiculares e figuras de mielina distribuídas pelo citoplasma (Fig. 9 E - F). Essas fibras e terminações nervosas parassimpáticas estavam distribuídas em uma discreta quantidade na cápsula articular, nos ligamentos intra-articulares e na periférica do disco articular. Nestes territórios, as mesmas podiam ser observadas no 
interior de feixes nervosos mistos e na túnica muscular de vasos sanguíneos. À semelhança do que ocorreu com as terminações nervosas simpáticas, no entanto em uma menor proporção, as fibras e terminações nervosas parassimpáticas estavam presentes na camada íntima e subíntima da membrana sinovial, ou associadas a células musculares lisas da vasculatura ou isoladas no tecido conjuntivo.

Embora não sendo o alvo principal de nosso estudo, a metodologia empregada no presente trabalho permitiu a visualização das fibras nervosas sensoriais, uma vez que este grupo de fibras nervosas apresentava as características ultra-estruturais condizentes com o padrão de normalidade. Diante disso, as fibras nervosas sensitivas, cujo diâmetro variou de 1 a $3 \mu \mathrm{m}$, foram identificadas pela preservação das estruturas sub-celulares típicas, tais como, neurofilamentos, neurotúbulos, mitocôndrias e vesículas envoltas por unidade membrana (Fig. 9 A - B). Tais fibras nervosas sensoriais foram observadas compondo a maioria dos feixes de fibras nervosas localizados na cápsula articular, na periferia do disco articular, nos ligamentos intra-articulares e na membrana sinovial, locais onde também observamos, difusamente distrubuídas no tecido conjuntivo, as porções terminais de tais fibras, ou seja, fibras nervosas isoladas, possivelmente muito próximo do ponto em que, ao perderem o envoltório de células de Schwann, se tranformam em receptores sensoriais.

\subsubsection{Documentação fotográfica}



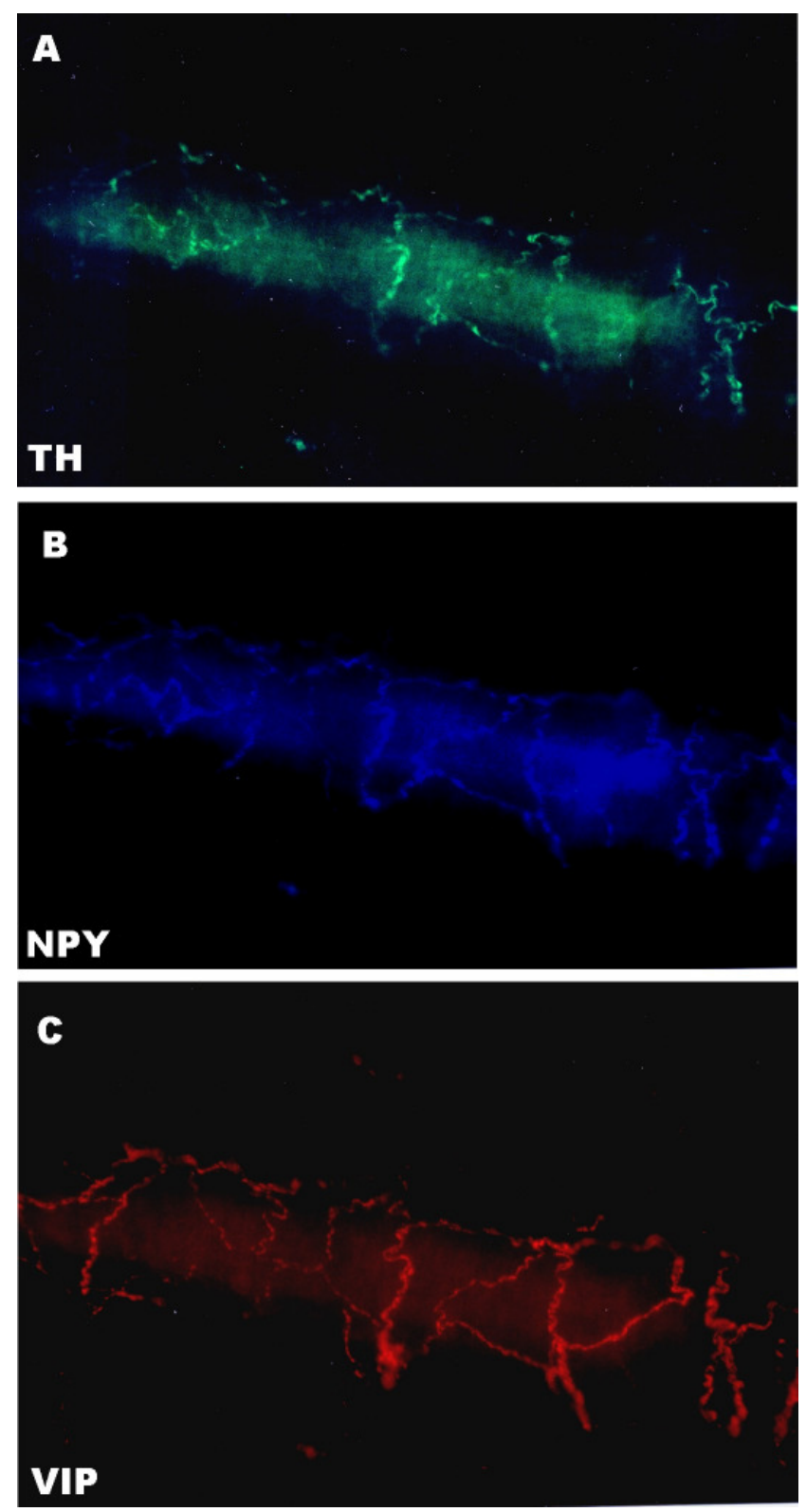

Figura 7. Fotomicrografia (epifluorescência) de um vaso sanguíneo envolto por fibras nervosas TH/NPY/VIP-IR. As fotomicrografias evidenciam, em um animal do grupo SX (ATM desprovida de inervação autonômica parassimpática e com inervação autonômica simpática intacta), um vaso sanguíneo, situado na periferia do disco articular, o qual se mostrou envolvido por fibras nervosas simpáticas simultaneamente imunorreativas à TH (A), NPY (B) e ao VIP (C). (aumento de 1500X). Abreviações: TH: tirosina hidroxilase; NPY: neuropeptídeo Y; VIP: peptídeo intestinal vasoativo; IR: imunorreativa. 

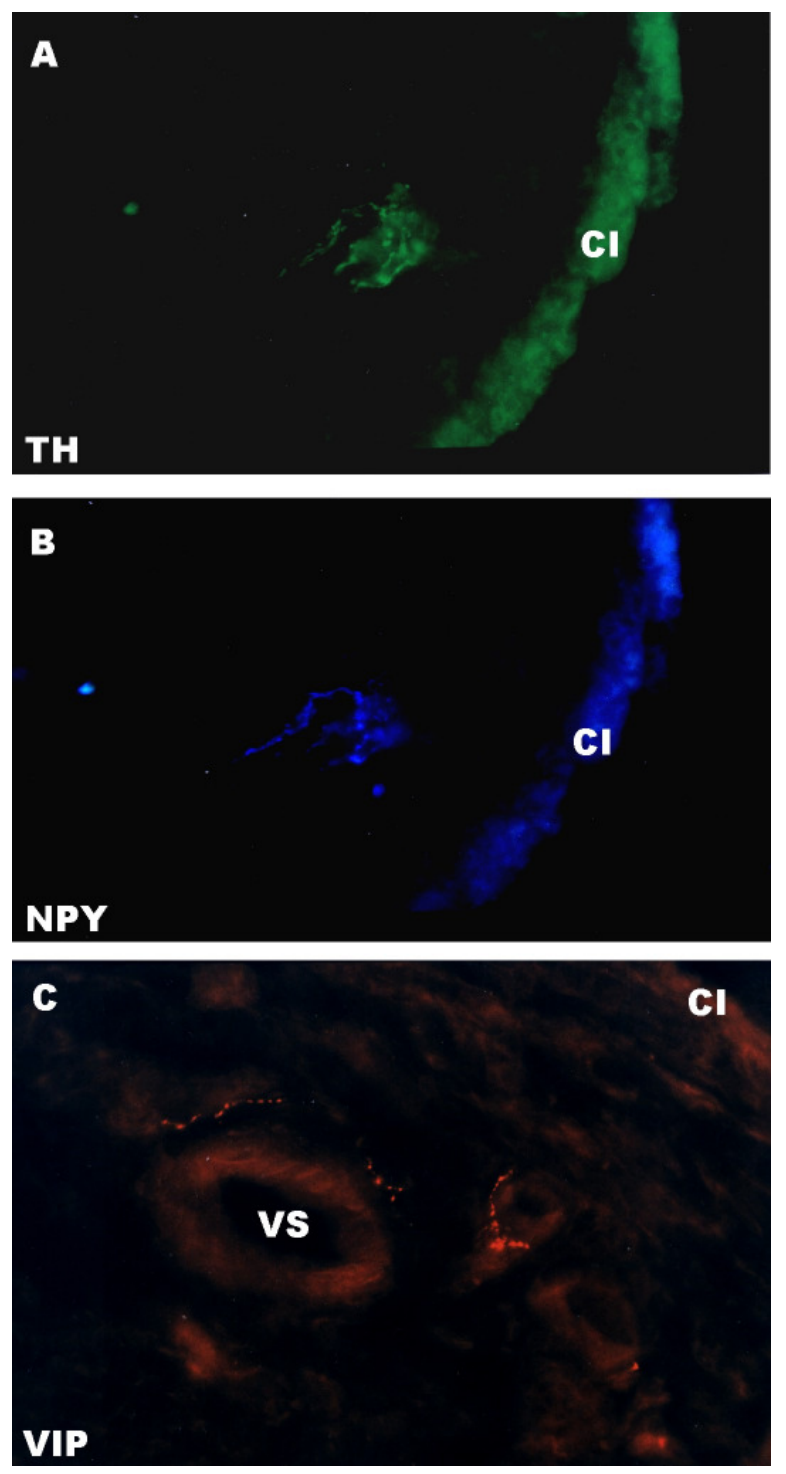

Figura 8. Fotomicrografia (epifluorescência) de fibra nervosa TH/NPY-IR na membrana sinovial e de fibra nervosa VIP-IR na circunjacência de um vaso sanguíneo. As fotomicrografias A e B evidenciam, em um animal do grupo SX (ATM desprovida de inervação autonômica parassimpática e com inervação autonômica simpática intacta), fibras e terminações nervosas simpáticas, situadas na camada subíntima da membrana sinovial, sem manterem relação com vaso sanguíneo, as quais se mostram simultaneamente imunorreativas à TH (A) e ao NPY (B) (aumento de $600 \mathrm{X}$ ). Em C, um corte tranversal de vasos sanguíneos situados na periferia do disco articular de um animal do grupo XP (ATM desprovida de inervação autonômica simpática e com inervação autonômica parasimpática intacta), o qual se mostra exclusivamente imunorreativo ao VIP (C) (aumento de 1500X). Abreviações: TH: tirosina hidroxilase; NPY: neuropeptídeo Y; VIP: peptídeo intestinal vasoativo; IR: imunorreativa; $\mathrm{Cl}$ : camada íntima da membrana sinovial, VS: luz de um vaso sanguíeno. 

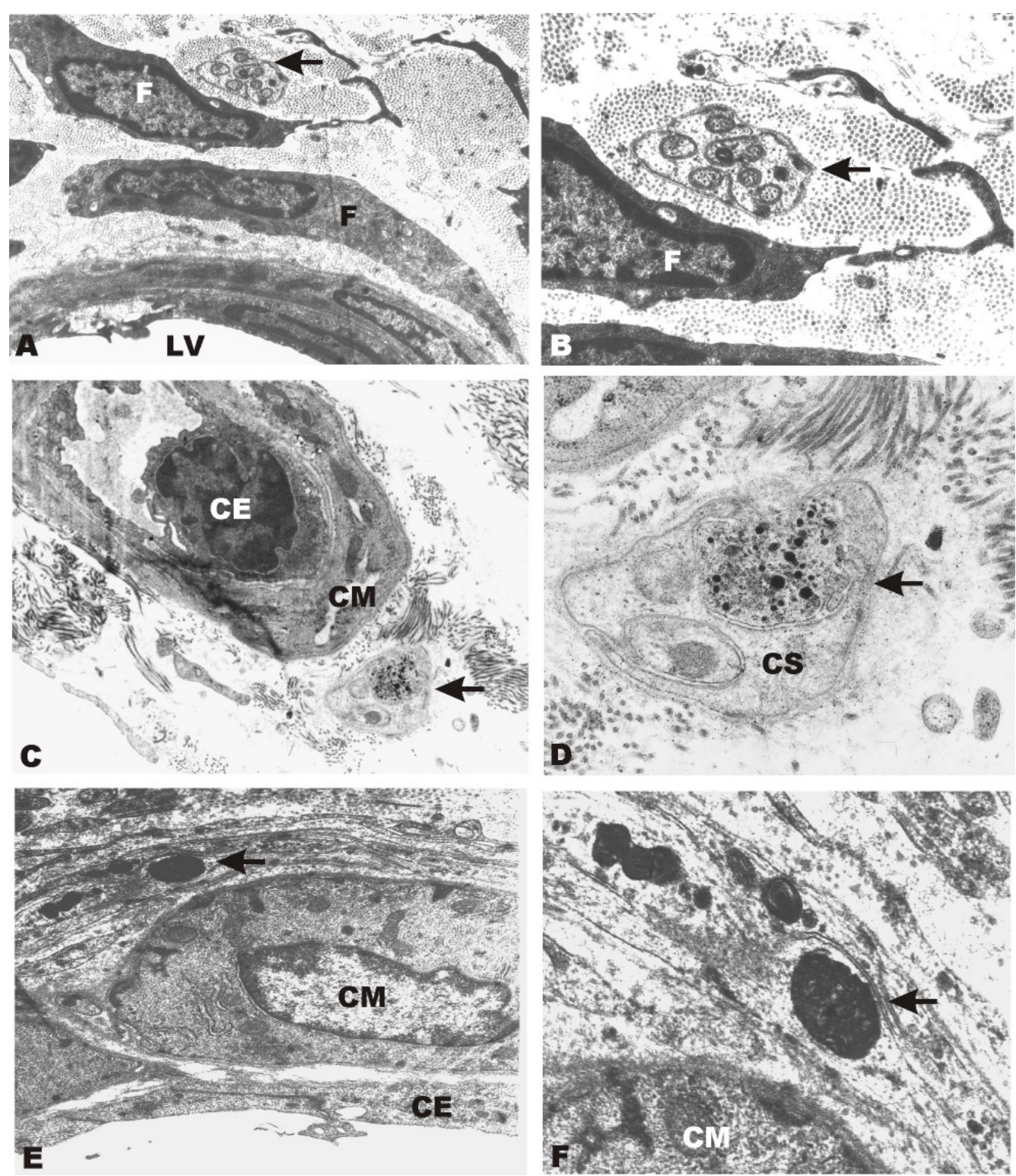

Figura 9. Elétron-micrografia de fibras e terminações nervosas sensoriais e autonômicas situadas nos ligamentos intra-articulares da ATM do rato. Em A, um conjunto de fibras nervosas sensoriais amielínicas (seta), situadas na adjacência de um vaso sanguíneo (aumento de $3.000 \mathrm{X}$ ), as quais estão visualizadas em maior aumento em B (aumento de 10.000X). Em C , uma terminação nervosa simpática (seta preta), situada próximo de uma arteríola (aumento 10.000X), a qual está sendo visualizadas em maior aumento em D (aumento de 20.000X), onde podemos observar a presença de um grande acúmulo de vesículas elétron-densas, indicativo da incorporação da 5-hidroxidopamina. Em $\mathbf{E}$ uma terminação nervosa parassimpática (seta) em processo de degeneração (ocasionado pela remoção cirúrgica do gânglio ótico) na circunjacência de um vaso sanguíneo (aumento de 10.000X), a qual está sendo visualizadas em maior aumento em $\mathbf{F}$ (aumento de 20.000X), onde podemos observar uma homogênea elétron-densidade ocupando toda sua área de corte. Abreviações: F: fibroblasto; LV: luz de um vaso sanguíneo; $\mathrm{CE}$ : célula endotelial; $\mathrm{CM}$ : célula muscular lisa; CS: célula de Schwann. 
Tabela 1. Diferentes componentes da ATM do rato e seu respectivo padrão de imunorreatividade* nos grupos controle e experimentais.

\begin{tabular}{|c|c|c|c|c|}
\hline \multirow{2}{*}{ LOCALIZAÇÃO } & \multicolumn{4}{|c|}{ GRUPOS } \\
\hline & SP & sx & $\mathbf{X P}$ & $\mathbf{X X}$ \\
\hline \multicolumn{5}{|c|}{ MEMBRANA SINOVIAL } \\
\hline $\begin{array}{l}\text { fibras nervosas } \\
\text { associadas à } \\
\text { vasculatura }\end{array}$ & $\begin{array}{c}\text { TH/NPY/VIP-IR } \\
\text { TH/NPY-IR } \\
\text { VIP-IR }\end{array}$ & $\begin{array}{c}\text { TH/NPY/VIP-IR } \\
\text { TH/NPY-IR }\end{array}$ & VIP-IR & - \\
\hline $\begin{array}{l}\text { fibras nervosas } \\
\text { isoladas }\end{array}$ & $\begin{array}{c}\text { TH/NPY/VIP-IR } \\
\text { TH/NPY-IR } \\
\text { VIP-IR }\end{array}$ & $\begin{array}{c}\text { TH/NPY/VIP-IR } \\
\text { TH/NPY-IR }\end{array}$ & VIP-IR & - \\
\hline \multicolumn{5}{|c|}{ CÁPSULA ARTICULAR } \\
\hline $\begin{array}{l}\text { fibras nervosas } \\
\text { associadas à } \\
\text { vasculatura }\end{array}$ & $\begin{array}{c}\text { TH/NPY/VIP-IR } \\
\text { TH/NPY-IR } \\
\text { VIP-IR }\end{array}$ & $\begin{array}{c}\text { TH/NPY/VIP-IR } \\
\text { TH/NPY-IR }\end{array}$ & VIP-IR & VIP-IR \\
\hline $\begin{array}{l}\text { fibras nervosas } \\
\text { isoladas }\end{array}$ & $\begin{array}{c}\text { TH/NPY/VIP-IR } \\
\text { TH/NPY-IR } \\
\text { VIP-IR }\end{array}$ & $\begin{array}{c}\text { TH/NPY/VIP-IR } \\
\text { TH/NPY-IR }\end{array}$ & VIP-IR & - \\
\hline $\begin{array}{l}\text { fibras nervosas } \\
\text { compondo } \\
\text { espessos feixes }\end{array}$ & $\begin{array}{c}\text { TH/NPY/VIP-IR } \\
\text { TH/NPY-IR } \\
\text { VIP-IR }\end{array}$ & $\begin{array}{c}\text { TH/NPY/VIP-IR } \\
\text { TH/NPY-IR }\end{array}$ & VIP-IR & VIP-IR \\
\hline \multicolumn{5}{|c|}{ LIGAMENTOS ARTICULARES } \\
\hline $\begin{array}{l}\text { fibras nervosas } \\
\text { associadas à } \\
\text { vasculatura }\end{array}$ & $\begin{array}{c}\text { TH/NPY/VIP-IR } \\
\text { TH/NPY-IR } \\
\text { VIP-IR }\end{array}$ & $\begin{array}{c}\text { TH/NPY/VIP-IR } \\
\text { TH/NPY-IR }\end{array}$ & VIP-IR & - \\
\hline $\begin{array}{l}\text { fibras nervosas } \\
\text { isoladas }\end{array}$ & $\begin{array}{c}\text { TH/NPY/VIP-IR } \\
\text { TH/NPY-IR } \\
\text { VIP-IR }\end{array}$ & $\begin{array}{c}\text { TH/NPY/VIP-IR } \\
\text { TH/NPY-IR }\end{array}$ & VIP-IR & - \\
\hline $\begin{array}{l}\text { fibras nervosas } \\
\text { compondo } \\
\text { espessos feixes }\end{array}$ & $\begin{array}{c}\text { TH/NPY/VIP-IR } \\
\text { TH/NPY-IR } \\
\text { VIP-IR }\end{array}$ & $\begin{array}{c}\text { TH/NPY/VIP-IR } \\
\text { TH/NPY-IR }\end{array}$ & VIP-IR & - \\
\hline \multicolumn{5}{|c|}{ DISCO ARTICULAR (PERIFERIA) } \\
\hline $\begin{array}{l}\text { fibras nervosas } \\
\text { associadas à } \\
\text { vasculatura }\end{array}$ & $\begin{array}{c}\text { TH/NPY/VIP-IR } \\
\text { TH/NPY-IR } \\
\text { VIP-IR }\end{array}$ & $\begin{array}{c}\text { TH/NPY/VIP-IR } \\
\text { TH/NPY-IR }\end{array}$ & VIP-IR & - \\
\hline $\begin{array}{l}\text { fibras nervosas } \\
\text { isoladas }\end{array}$ & $\begin{array}{c}\text { TH/NPY/VIP-IR } \\
\text { TH/NPY-IR } \\
\text { VIP-IR }\end{array}$ & $\begin{array}{c}\text { TH/NPY/VIP-IR } \\
\text { TH/NPY-IR }\end{array}$ & VIP-IR & - \\
\hline
\end{tabular}

* devido a extrema escassez de fibras nervosas exclusivamente TH-IR na ATM do rato estas não foram inseridas nesta tabela. 


\subsection{DISCUSSÃO}

O presente estudo demonstrou os principais padrões de imunorreatividade, no que se refere a expressão de TH, NPY e VIP apresentado pelas fibras e terminações nervosas autonômicas que inervam a ATM do rato, assim como, sua distribuição tanto em nível estrutural quanto ultra-estrutural. Aparentemente este estudo é o pioneiro na descrição da distribuição diferencial das fibras e terminações nervosas de origem autonômica simpática e parassimpática na ATM do rato. Além disso, foi evidenciado que o VIP, um neuropeptídeo em evidência nos últimos anos devido ao seu potencial terapêutico, na ATM, não é encontrado apenas em fibras e terminações nervosas parassimpáticas, como sugerido anteriormente por Kido et al. (2001), sendo também detectado em uma considerável quantidade de fibras nervosas autonômicas simpáticas e, provavelmente em fibras nervosas sensitivas.

\subsubsection{Caracterização neuroquímica das fibras e terminações nervosas autonômicas que inervam a ATM do rato}

Neste estudo empregamos uma metodologia que possibilitou a caracterização das fibras e terminações nervosas autonômicas, simpáticas e parassimpáticas, quanto a presença da TH, do NPY e do VIP na ATM do rato. Para tal propósito, submetemos cortes histológicos de ATMs à reação de tripla marcação imunoistoquímica, empregando-se simultaneamente três anticorpos espécieespecíficos, anti-TH do rato gerado em ovelha, anti-NPY de rato gerado em coelho e anti-VIP de rato gerado em cobaia. As reações imunoistoquímicas foram executadas em ATMs sob as seguintes condições: inervação intacta, desprovidas de inervação simpática, desprovidas de inervação parassimpática ou, desprovidas tanto de inervação simpática quanto de parassimpática. A associação entre a tripla marcação imunoistoquímica e a desnervação seletiva a qual foram submetidos os animais neste experimento, nos permitiu, com muita clareza, a identificação e a caracterização neuroquímicas das fibras e terminações nervosas autonômicas nesta articulação.

Constatamos que as fibras e terminações nervosas simpáticas predominam em relação às parassimpáticas $e$, apresentam os seguintes padrões de 
imunorreatividade: TH-IR, TH/NPY-IR e TH/NPY/VIP-IR, sendo a primeira condição raramente encontrada, enquanto que as últimas se mostraram abundantes. Nossos resultados estão de acordo com aqueles observados por Ackermann et al. (2001) no joelho de ratos, todavia, corroboram apenas em parte com um trabalho prévio que demonstrou a presença de fibras nervosas simpáticas expressando exclusivamente TH e, simultaneamente TH e NPY na ATM do rato (KIDO et al., 2001). Neste último trabalho, embora não tenha sido utilizada uma técnica imunoistoquímica que simultaneamente fosse capaz de detectar a TH, o NPY e o VIP, como a empregada no presente estudo, os resultados obtidos advindos da detecção individualizada dos referidos neuropeptídeos e da enzima, divergem substancialmente dos nossos, uma vez que não houve coincidência na distribuição de fibras TH-IR e TH/NPY-IR com fibras expressando imunorreatividade ao VIP, as quais foram tidas por estes autores como sendo fibras nervosas autonômicas parassimpáticas. Comprovamos em nosso estudo que as fibras nervosas TH/NPY/VIP-IR, além das TH-IR e TH/NPY-IR, são originadas de neurônios ganglionares simpáticos alojados no gânglio cervical superior e estrelado, ambos situados no lado ipsilateral, uma vez que a remoção cirúrgica destes gânglios determinou o desaparecimento completo de tais fibras. Auxiliando-nos na sustentenção dos resultados, Messina e Bell (1993) constataram que no gânglio cervical superior a maioria dos neurônios TH-IR, mas não todos, expressam também o NPY, sendo assim podemos inferir que, as poucas fibras exclusivamente TH-IR e a grande quantidade de fibras TH/NPY-IR observadas em nosso trabalho, seja o reflexo dessa proporção de neurônios ganglionares exclusivamente TH-IR e TH/NPY-IR alojados nesse gânglio simpático. Adicionado a isto, Kummer (1990) reportou que em uma grande parcela dos neurônios situados no gânglio cervical superior há coexistência entre NPY e VIP, o que ainda baseado em dados proporcionais poderia explicar a presença desta substancial quantidade de fibras nervosas TH/NPY/VIP-IR verificada em nosso estudo.

$\mathrm{Na}$ ATM a grande quantidade de fibras nervosas TH/NPY-IR e TH/NPY/VIPIR foram observadas na circunjacência tanto de vasos sanguíneos de maior calibre associados à cápsula articular, quanto nos muitos vasos sanguíneos de menor calibre distribuídos por todos os componentes desta articulação. Nestes últimos também verificamos, com um trajeto bastante diferente daquele apresentado pelas fibras nervosas TH/NPY-IR e TH/NPY/VIP-IR, algumas poucas fibras nervosas 
parassimpáticas exclusivamente VIP-IR, as quais foram desta forma identificadas, uma vez que a remoção cirúrgica do gânglio ótico resultou em sua total depleção. Ackermann et al. (2001), descrevendo a inervação autonômica do joelho de ratos, reportaram que os maiores vasos sanguíneos dessa articulação apresentavam predominantemente fibras nervosas com fenótipo supostamente de autonômicas simpáticas, ou seja, TH/NPY-IR, ao passo que os vasos sanguíneos de menor calibre se relacionavam com fibras nervosas expressando um fenótipo mais condizente com o de autonômicas parassimpáticas, ou seja, exclusivamente imunorreativas ao VIP. Tais dados, quando confrontados com os apresentados em nosso trabalho apontam para uma condição em que as articulações sinoviais não compartilham padrões semelhantes de inervação autonômica na vasculatura, especialmente porque na ATM a maior parte das fibras nervosas situadas nas circunjacências dos vasos sanguíneos de pequeno calibre, além de conterem VIP, também se mostram imunorreativas à TH e ao NPY.

Nosso trabalho apresentou, pela primeira vez, evidências concretas de que a ATM mostra-se inervada por um discreto contingente de fibras nervosas autonômicas parassimpáticas. Tais fibras nervosas foram identificadas através da desnervação seletiva empregada em nosso estudo e, por estarem expressando imunorreatividade ao VIP, um neuropeptídeo expresso por praticamente todos os neurônios ganglionares parassimpáticos, onde coexiste com a enzima colina acetiltransferase, um marcador de neurônios colinérgicos (LEBLANC et al., 1987). Nossos dados estão de acordo com um estudo realizado por Casatti et al. (1999), os quais reportaram uma pequena quantidade de neurônios parassimpáticos marcados no gânglio ótico, após a injeção de traçador neuronal retrógrado na ATM do rato. Em contrapartida, neste último trabalho os autores relataram uma grande quantidade de pericários marcados nos gânglios cervical superior e trigeminal, os quais alojam respectivamente os neurônios ganglionares simpáticos e sensoriais que enviam fibras nervosas para a ATM. Diante disso sugerimos que a diferença na densidade de fibras nervosas autonômicas simpáticas e parassimpáticas observada no presente trabalho seja proporcional à quantidade de neurônios que inervam essa articulação.

Nosso estudo demonstrou que as ATMs desprovidas de inervação autonômica simpática, exibem algumas poucas fibras nervosas VIP-IR na 
circunjacência de vasos sanguíneos difusamente distribuídos por toda a articulação, especialmente, na membrana sinovial, onde também verificamos a presença de algumas fibras nervosas vipérgicas isoladas, ou seja, não associadas a vasos sanguíneos. Além disso, nas ATMs desprovidas de inervação simpática e parassimpática, observamos a permanência de fibras nervosas VIP-IR apenas envolvendo alguns vasos sanguíneos mais calibrosos associados à cápsula articular. Diante disso, podemos afirmar com segurança que as fibras nervosas exclusivamente imunorreativas ao VIP situadas nas adjacências dos vasos sanguíneos distribuídos por toda a articulação e, aquelas isoladas presentes especialmente na membrana sinovial, são oriundos de neurônios ganglionares parassimpáticos localizados no gânglio ótico. Por conseguinte, as fibras nervosas exclusivamente VIP-IR que permaneceram na circunjacência de vasos sanguíneos mais calibrosos associados à cápsula articular, quando a ATM se mostrava desprovida de inervação simpática e parassimpática, acreditamos se tratar de fibras nervosas sensoriais. Algumas evidências suportam nossa suposição, a primeira delas é que em um estudo piloto realizado recentemente em nosso laboratório, utilizando traçamento neuronal retrógrado e imunoistoquímica, identificamos neurônios sensoriais primários, do gânglio trigeminal, que enviam fibras nervosas para a ATM do rato apresentando imunorreatividade ao VIP. Ademais, descartamos a possibilidade de tais fibras nervosas exclusivamente VIP-IR serem provenientes de outros gânglios parassimpáticos, como os gânglios ciliar, esfenopalatino e submandibular, uma vez que Casatti et al. (1999) relataram a presença de pericários parassimpáticos marcados apenas no gânglio ótico, após a deposição de traçador neuronal retrógrado na ATM do rato. Contrariamente, Uddman et al. (1998), em um estudo semelhante, relataram a presença de corpos celulares de neurônios parassimpáticos marcados também no gânglio esfenopalatino. Todavia acreditamos que no trabalho citado houve marcação neuronal retrógrada inespecífica, baseado na quantidade de neurônios marcados, cerca de oito vezes maior que a reportada em outros estudos, e nos gânglios que alojavam tais neurônios, o que também não coincide com a maioria dos trabalhos que se utilizaram desta metodologia (CASATTI et al., 1999; DAMICO, 1998; ERVOLINO, 2001). Por fim, desconsideramos também a possibilidade de que as fibras exclusivamente vipérgica, observadas em ATMs desprovidas de inervação autonômica, pudessem ter como procedência neurônios 
localizados no gânglio ótico contralateral, considerando que Damico (1998), após a deposição de traçador neuronal na ATM do rato, não constou a presença de células marcadas no gânglio ótico contralateral.

Em nosso estudo, além das fibras nervosas VIP-IR estarem presentes na circunjacência de vasos sanguíneos, também foram observadas, em uma menor proporção, isoladas no tecido conjuntivo, especialmente na membrana sinovial, o que está de acordo com estudos prévios realizados em articulações sinoviais (ELFVIN et al., 1998; ACKERMANN et al., 2001; KIDO et al., 2001). Tais autores sugerem que a disposição de tais fibras neuropeptidérgicas, reflete a capacidade dos neuropeptídeos de exercerem controle sobre a vasculatura e, provavelmente efetuarem alguma ação parácrina sobre a atividade das células que compõem a membrana sinovial e sistema imunológico (ELFVIN et al., 1998; ACKERMANN et al., 2001; KIDO et al., 2001). O VIP modula a imunidade inata e a adaptativa, exercendo predominantemente uma ação direta sobre monócitos, macrófagos e linfócitos $T$ auxiliares tipo 1, tipo 2 e regulatórios, resultando em imunossupressão e uma potente ação antiinflamatória, o que atualmente o coloca como um potencial candidato para uso terapêutico em doenças inflamatórias crônicas (DELGADO et al., 2002; GANEA e DELGADO, 2003; DELGADO e GANEA, 2003; DELGADO et al., 2004; GONZALEZ-REY e DELGADO, 2007). Trabalhos recentes reportam que os principais sinais e sintomas da artrite induzida por colágeno, um modelo experimental comunente utilizado, são drasticamente reduzidos após a administração de VIP (DELGADO et al., 2001; DELGADO et al., 2002; FOEY et al., 2003; YIN et al., 2005; JUARRANZ et al., 2005; GONZALEZ-REY et al., 2006, GUTIÉRREZ-CAÑAS et al., 2008).

$\mathrm{Na}$ literatura não há dados que especifiquem como age o VIP de origem simpática, parassimpática e sensorial em uma articulação sinovial e, se há diferença na atuação deste neuropeptídeo dependendo de sua origem. Sabe-se que sua atuação é mediada por receptores metabotrópicos acoplados a proteína G, denominados de VPAC1 e VPAC2, com os quais o VIP e o peptídeo ativador da adenilato-ciclase pituitária (PACAP) interagem com alta afinidade e com o mesmo grau de equivalência (LABURTHE et al., 2002; COUVINEAU et al., 2003). Estes receptores foram observados em células musculares lisas (FAHRENKRUG et al., 2000), linfócitos T (DELGADO e GANEA, 2003), monócitos, macrófagos e 
sinoviócitos (GUTKIND et al., 1988) e, em neurônios sensoriais primários de pequeno diâmetro alojados no gânglio trigeminal (CHAUDHARY e BAUMANN, 2002), revelando que o VIP apresenta uma gama de possibilidades de atuação, que vão desde a modulação do tônus vascular e da resposta imunológica, até uma suposta participação na atividade de neurônios sensoriais. Diante do exposto inferimos que embora a inervação parassimpática na ATM seja representada por um pequeno contingente de fibras nervosas, as substâncias liberados por tais fibras, como o VIP, por exemplo, potencialmente podem mediar a modulação de importantes funções que interferem direta ou indiretamente na homeostase articular e na patogenia da artrite. Vale a pena salientar que nosso trabalho apontou que VIP apresenta inúmeras fontes neurogênicas, ou seja, fibras nervosas autonômicas e sensoriais, porém deve-se acrescentar que este neuropeptídeo também possui outras fontes de produção, uma vez que algumas células do sistema imunológico, especialmente linfócitos, também secretam VIP (LECETA et al., 1996; MARTINEZ et al., 1999).

Com relação à inervação simpática da ATM do rato, corroborando com nossos achados, alguns trabalhos relataram a distribuição de fibras nervosas simpáticas imunorreativas ao NPY e a enzima TH, nas adjacências de vasos sanguíneos situados na cápsula articular, nos ligamentos intra-articulares, na periferia do disco articular e na membrana sinovial (ICHIKAWA et al., 1989; SHIMIZU et al., 1996; HAEUCHI et al., 1999; KIDO et al., 2001). As fibras NPY-IR presentes na ATM, segundo trabalhos prévios (UDDMAN et al., 1998; DAMICO, 1998; KIDO et al., 2001) e o presente estudo, provêm de neurônios ganglionares simpáticos alojados nos gânglios cervical superior e estrelado. Damico (1998), em um estudo aliando traçamento neuronal e imunoistoquímica para a deteção NPY nos gânglios cervical superior, estrelado e ótico, relatou que respectivamente, 78\%, 77\% e 10\% dos neurônios situados nestes gânglios e, que enviam fibras nervosas para ATM, se mostram imunorreativos ao NPY. Além disso, no gânglio ótico cerca de $70 \%$ dos neurônios são imunorreativos ao NPY (LEBLANC et al., 1983). No entanto, em nosso estudo, após a remoção do gânglio cervical superior e estrelado, verificamos uma ausência total de fibras contendo NPY, restando apenas fibras nervosas vipérgicas. Diante disso devemos levar em consideração que embora o corpo celular de um neurônio expresse imunorreatividade a um determinado neuropeptídeo, tal 
fato não implica necessariamente que a quantidade desse neuromediador existente em seus prolongamentos possa ser suficiente para ser detectada imunoistoquimicamente. Similarmente ao ocorrido em nosso trabalho, o NPY foi detectado na maioria dos neurônios do gânglio ciliar do rato que inervam a íris e corpo ciliar, não se observando fibras nervosas NPY-IR após a realização de simpatectomia (LEBLANC e LANDIS, 1988).

Um aspecto interessante verificado em nosso trabalho, que está de acordo Kido et al. (2001), é o fato de que a quase totalidade de neurônios que expressam TH também expressarem NPY. Assim sendo, a atividade das fibras nervosas simpáticas pode levar a liberação de noradrenalina e NPY, e em algumas circunstâncias de VIP, quando esse estiver também co-localizado com os anteriores, no entanto a liberação destes neuropeptídeos está relacionada com a frequência de potenciais de ação nestas fibras (MIAO et al., 1996, DONOSO et al., 2006).

O NPY exerce seus efeitos em nível pré ou pós-sináptico, interagindo com receptores metabotrópicos acoplados a proteína $G$ e denominados de Y1, Y2, Y4, Y5 e Y6 (MICHEL et al., 1998; ABE et al., 2007). Os três efeitos básicos do NPY na junção neuroefetora são: uma resposta pós-juncional direta, responsável por promover uma potente vasoconstrição, uma potenciação pós-juncional da resposta vasoconstritora desencadeada pela noradrenalina e, uma inibição pré-juncional, que modula a liberação de noradrenalina (DONOSO et al., 2006). Quando infusionado em articulações sinoviais o NPY promove uma potente vasoconstrição (FUNK et al., 1995) e ainda altera significativamente a excitabilidade de receptores sensoriais, reduzindo seu limiar de excitação (JUST e HEPPELMAN, 2001). De acordo com este último, Naveilhan et al. (2001), reportaram que o NPY pode interagir com receptores situados nas terminações nervosas sensoriais e estimular a liberação de neuropeptídeos com ação pró-inflamatória, como a SP. Além destas funções o NPY apresenta uma interação recíproca com o sistema imunológico, modulando a produção e liberação de outros mediadores (ELENKOV et al., 2000; BEDOUI et al., 2003).

Há um consistente corpo de evidências que suporta o envolvimento do sistema nervoso autônomo, especificamente o componente simpático, na patogenia da artrite. Levine et al. (1986), utilizaram métodos de desnervação farmacológica para determinar a possível participação da inervação na evolução do processo 
inflamatório, decorrente de artrite induzida experimentalmente. Nesse estudo foi verificado que a administração neonatal de capsaicina, que elimina fibras aferentes de pequeno diâmetro, reduz significativamente a severidade da artrite. Similarmente a administração de guanetidina, que promove simpatectomia química, também reduz consideravelmente a gravidade do quadro artrítico. Além disso a participação de fibras nervosas simpáticas na evolução do processo inflamatório articular pode ser observada em ratos portadores de hipertensão arterial espontânea, os quais apresentam o tônus simpático aumentado, e por conseguinte desenvolveram uma artrite mais severa, quando comparados com ratos normotensos (LEVINE et al., 1986).

Ahmed et al. (1995) demonstraram um aumento na quantidade de fibras nervosas NPY-IR e um aumento significante na concentração deste neuropetídeo no joelho de ratos sob vigência de artrite induzida experimentalmente. Um aumento na concentração deste neuropeptídeo também foi reportado quando a ATM de ratos está sob vigência de artrite induzida experimentalmente (LUNDEBERG et al., 1996). Similarmente pacientes portadores de desordens temporomandibulares, tanto de natureza inflamatória quanto degenerativa, apresentaram um substancial aumento na concentração deste neuropeptídeo (ALSTERGREN et al., 1995).

Em nosso trabalho também empregamos um marcador exclusivo de fibras nervosas pós-ganglionares simpáticas, a TH, uma enzima chave na biossíntese de noradrenalina. Como demonstrado em estudos anteriores, evidenciamos fibras nervosas imunorrativas à $\mathrm{TH}$, principalmente associadas com vasos sanguíneos (ICHIKAWA et al., 1989; KIDO et al., 2001; ACKERMANN et al., 2001). Esta situação claramente denota a clássica função da noradrenalina no controle do tônus vascular, o qual é mediado via receptores adrenérgicos localizados nas células musculares lisas que compõem a túnica média dos vasos sanguíneos (MIAO et al., 1996; GREEN et al., 1993). Além disso, a noradrenalina também exerce uma função modulatória sobre algumas células do sistema imunológico, a qual ocorre através do seu acoplamento com receptores alfa e beta-adrenérgicos situados em linfócitos $T$, linfócitos B, macrófagos e mastócitos (ELENKOV et al., 2000). As terminações nervosas noradrenérgicas também desempenham um papel fundamental no extravasamento plasmático e na sensibilização de nociceptores (FERREIRA e NAKAMURA, 1987; LEVINE et al., 1993). No primeiro caso, a participação das 
terminações nervosas simpáticas noradrenérgicas ocorre de maneira indireta sobre o extravasamento plasmático. A bradicinina se acopla a receptores específicos situados nas varicosidades simpáticas e desencadeia a produção de ácido araquidônico, o qual via cicloxigenase, resulta na síntese e liberação de prostaglandina, especialmente PGE2, que atua nas vênulas, potencializando o extravasamento plasmático (LEVINE et al., 1993; MIAO et al., 1996; GREEN et al., 1993). Da mesma forma, a noradrenalina liberada por varicosidades simpáticas, além de exercer seu efeito parácrino, também exerce um efeito autócrino, através de auto-receptores alfa-2 adrenérgicos, cuja ativação desencadeia a produção de ácido araquidônico, que sob a ação da ciclooxigenase, origina a prostaglandina I2, a qual atua em nociceptores, diminuindo o limiar e consequentemente colaborando com o surgimento de hiperalgesia e alodinia (LEVINE et al., 1993). Diante do exposto acima e da grande densidade de fibras nervosas simpáticas existentes na ATM fica claro a influência do sistema nervoso simpático na homeostase, na evolução da artrite e no processamento da informação nociceptiva nessa articulação.

Em resumo constatamos que a inervação autonômica da ATM do rato é representada por um grande contingente de fibras e terminações nervosas simpáticas e, uma discreta quantidade de fibras e terminações nervosas parassimpáticas. A constituição neuroquímica de tais fibras é consideravelmente complexa, no que se refere a expressão de TH, NPY e VIP, exibindo as fibras nervosas simpáticas os seguintes fenótipos TH-IR, TH/NPY-IR, TH/NPY/VIP-IR, enquanto que as fibras parassimpáticas se mostraram exclusivamente VIP-IR. Tanto as fibras nervosas simpáticas quanto as parassimpáticas foram encontradas, guardando suas devidas proporções, na circunjacência de vasos sanguíneos situados em todos componentes da ATM, e isoladas no tecido conjuntivo, especialmente da membrana sinovial. A única exceção foi a porção central do disco articular, a qual se apresenta desprovida de inervação.

\subsubsection{Análise topográfica ultra-estrutural das fibras e terminações nervosas autonômicas na ATM do rato}

Nesse estudo empregamos uma metodologia que possibilitou analisarmos simultaneamente, em nível ultra-estrutural, a distribuição das fibras e terminações 
nervosas sensoriais, simpáticas e parassimpáticas na ATM do rato. Para tal propósito, mantivemos intacta a inervação sensorial, induzimos a degeneração anterógrada das fibras nervosas parassimpáticas, através da remoção cirúrgica do gânglio ótico e, identificamos as terminações nervosas simpáticas pelo grande acúmulo de vesículas elétron-densas contendo a 5-hidroxidopamina, a qual foi administrada horas antes da eutanásia e foi incorporada pelas terminações nervosas simpáticas.

A distribuição ultra-estrutural das fibras e terminações nervosas sensoriais foi extensiva a todos os componentes da articulação, ou seja, cápsula articular, periféria do disco articular, ligamentos intra-articular e na membrana sinovial, exceção feita apenas a parte central do disco articular, o que está de acordo com estudos prévios (KIDO et al., 1991; KIDO et al., 1995). Estas fibras nervosas sensoriais foram visualizadas em feixes nervosos constituídos de fibras nervosas mielínicas (com diâmetro médio de 1 a $3 \mu \mathrm{m}$ ) e amielínicas (diâmetro médio de $1 \mu \mathrm{m}$ ), associadas à parede de vasos sanguíneos e isoladas no tecido conjuntivo, como reportado por Kido et al. (1995). Vale a pena ressaltar a presença de terminações nervosos aparentemente sensoriais muito próximos das células $A$ e $B$ da camada íntima da membrana sinovial, possibilitando sugerir um papel modulatório executado por estes receptores sensoriais, uma vez que é fato sua potente função eferente, especialmente em articulações sinoviais. Alguns trabalhos relataram a presença de terminações nervosas sensoriais imunorreativas à SP e ao CGRP na camada íntima e subíntima da membrana sinovial, o que corrobora com nossos achados (ICHIKAWA et al., 1989; KIDO et al., 1993; KIDO et al., 1995; SHIMIZU et al., 1996; UDDMAN et al., 1998). Kido et al. (1995) mencionaram que algumas terminações nervosas sensoriais presentes na camada íntima da membrana sinovial estavam situados a uma distância de cerca de $75 \mathrm{~nm}$ das células A. Todavia, no presente estudo nenhum das terminações nervosas supostamente sensoriais que foram analisadas estavam situadas a uma distância menor que $1 \mu \mathrm{m}$ tanto das células $A$, assim como das células B. Podemos especular que a diminuta distância observada entre terminações nervosas sensoriais e células $A$ encontradas no trabalho de Kido et al. (1995), os quais sugeriram um controle neural mais estreito que o do tipo parácrino, pode ter sido resultado da atividade destas células da membrana sinovial na tentativa de fagocitar o traçador neuronal utilizado, a peroxidase da raiz forte 
conjugada com a aglutinina do germe de trigo (HRP-WGA), uma vez que esta substância após ter sido depositada no gânglio trigeminal, transportada via fluxo axonal anterogradamente para os receptores sensoriais situados na ATM, foi substancialmente exocitada por estas terminações e se difundiram na matriz extracelular adjacentes, como mencionado por estes autores.

Levando-se em consideração ao diâmetro apresentado pelas fibras nervosas sensoriais, podemos concluir que aquelas amielínicas e mielínicas são respectivamente as fibras nervosas $\mathrm{C}$ e $A \delta$, as quais originam terminações nervosas livres polimodais, excitadas tanto por estímulos de natureza química, mecânica e elétrica e térmica (BROTON et al., 1988; TAKEUCHI et al., 2001; TAKEUCHI et al., 2003; MAIXNER et al., 1995). Tais dados corroboram com os achados que se utilizaram de traçadores neuronais retrógrados depositados na ATM do rato (WIDENFALK e WIBERG, 1990; UDDMAN et al., 1998; CASATTI et al., 1999; YOSHIDA et al., 1999). Estes trabalhos revelaram que a principal origem das fibras nervosas sensoriais dessa articulação, são neurônios sensoriais primários de pequeno diâmetro situados predominantemente no gânglio trigeminal, condizente com o seu envolvimento com o processamento da informação nociceptiva.

Com relação à inervação simpática, o método de identificação empregado em nosso estudo foi aquele preconizado por Transen e Thoenen (1967). Esse método baseia-se na administração de 5-OHDA previamente à eutanásia. Os terminais nervosos simpáticos incorporam a 5-OHDA em vesículas que se concentram em grande quantidade nas terminações nervosas simpáticas. Aliado a esse fato, a 5-OHDA apresenta grande afinidade pelos metais pesados empregados em microscopia eletrônica, exibindo os terminais nervosos simpáticos um grande acúmulo de vesículas elétron-densas. Esse método se mostrou eficaz para identicar as terminações nervosas simpáticas e dentre suas vantagens estão o baixo custo e facilidade de execução. Trabalhos mais recentes também têm se utilizado deste método de marcação, apresentando resultados satisfatórios em vários órgão, tais como na polpa dentária (AVERY et al., 1980), no pâncreas (LIU et al., 1997), na íris (SANDOW e HILL, 1999) e em músculo estriado esquelético (TAKEUCHI et al., 2003).

As terminações nervosas simpáticas, em nosso trabalho, foram caracterizados pela presença simultânea de diferentes tipos de vesículas com 
diâmetro variável de 10 a 150 nm, com conteúdo elétron-denso que ocupava todo o seu volume (vesículas tipo I, segundo Chiba, 1973), ou que ocupava apenas um dos pólos de tais vesículas (vesícula tipo II, segundo Chiba, 1973) após injeção intraperitoneal de três doses de $100 \mathrm{mg} / \mathrm{kg}$ de peso corporal, aplicadas três, duas e uma hora antes da eutanásia. Os aspectos ultra-estruturais desses terminais se assemelharam aos relatados em estudos anteriormente (CHIBA 1973; LIU et al., 1997; SANDOW e HILL, 1999; TAKEUCHI et al., 2003). Entretanto, Avery et al. (1980) estudando os terminais nervosos simpáticos em outro território orofacial, polpa dentária de terceiros molares de ratos, também mencionaram a presença de material eletron-denso multi-lobulado, preenchendo extensa área dos terminais nervosos simpáticos após tratamento com doses menores de 5-OHDA, 20 mg/kg. Possivelmente essa configuração ultra-estrutural seja decorrente do tratamento de descalcificação dos dentes molares, como os próprios autores salientaram.

Atualmente, somente o presente trabalho e aquele de Kido et al. (2001), mostraram as características ultra-estruturais e localização precisa dos terminais nervosos simpáticos em articulações sinoviais, sendo que ambos trabalhos objetivaram a ATM do rato. Entretanto, Kido et al. (2001) conseguiram identificar os terminais nervosos simpáticos devido à marcação imunoistoquímica com o anticorpo anti-NPY, enquanto nós empregamos um método de marcação extensivo que evidencia todos os terminais nervosos simpáticos.

As fibras e terminações nervosas simpáticas, no presente trabalho, estavam distribuídos na porção periférica do disco articular e cápsula articular. Principalmente associados à parede de arteríolas ou mesmo isolados no tecido conjuntivo. $\mathrm{Na}$ membrana sinovial, tais terminais foram observados na camada subíntima e dificilmente foi possível discerní-los na camada íntima entre as células A e B. Kido et al. (2001), mencionaram a presença de terminais nervosos simpáticos, imunorreativos ao NPY em microscopia eletrônica de transmissão, próximos às células $A$ e $B$. No presente trabalho, essa íntima associação com células $A$ e $B$, tornou-se dificultada, uma vez que alguns perfis celulares que assemelhavam ser de prolongamentos celulares em secção transversal oval ou circular também pareciam exibir diminutas vesículas elétron-densas, impossibilitando uma identificação segura se tais estruturas pertenciam ou não a elementos neurais. Em um trabalho recente (VANDENABEELE et al., 2003) no qual fragmentos de membrana sinovial que foram 
mantidos em uma solução fisiológica adicionada com 5-OHDA, possibilitou evidenciar que as células B incorporam esta substância, a semelhança das varicosidades simpáticas. Tais autores especularam que provavelmente as células $B$ têm propriedades de sintetizarem aminas biogênicas, os neurônios ganglionares simpáticos, e poderiam ser consideradas células do sistema APUD (amine precursors uptake and decarboxylation). Aliado a essa descoberta, outro estudo revelou que articulações sinoviais submetidas a desnervação simpática, passam a obter um suprimento adrenérgico proveniente da atividade celular da membrana sinovial (MILLER et al., 2000; MILLER et al., 2002). Esses dados, sustentam nossas evidências ultra-estruturais, que após o tratamento com 5-OHDA, tivemos dificuldade em afirmar com segurança a distribuição dos terminais nervosos simpáticos na camada íntima da membrana sinovial, possivelmente por que as células B também devem estar incorporando a 5-OHDA injetada sistemicamente e passam a exibir algumas vesículas elétron-densas.

Com relação à inervação parassimpática, nosso estudo demonstrou que as fibras e terminais nervosos parassimpáticos estavam associados predominantemente à vasos sanguíneos. Ocasionalmente, foram encontradas imersas em feixes nervosos mistos. Tais fibras e terminais nervosos estavam posicionados na camada subíntima da membrana sinovial assim como na porção subsinovial da cápsula articular como da periferia do disco articular. Essas fibras e terminais nervosos parassimpáticos foram identificados por apresentarem diâmetro médio de $1 \mu \mathrm{m}$ com características ultra-estruturais de degeneração, tais como citoplasma repleto de material homogêneo e/ou granuloso com intensa elétrondensidade, ou mesmo apresentando figuras de mielina. Essas características se assemelham àquelas citadas em outros trabalhos que se utilizaram degeneração anterógrada de fibras e terminais nervosos (ANDRES et al., 1985; LAPA e BAUER, 1996). Algumas fibras e terminais nervosos parassimpáticos podem não ter sido identificados por ainda não exibirem características típicas de degeneração, haja vista que sacrificamos os animais após 24 horas da ganglionectomia. Empregando, tempos maiores de sacrifícios pós-ganglionectomia, por exemplo, 48 horas, raramente conseguimos observar com segurança, fibras e terminais nervosos degenerados ou em processo de degeneração. Aparentemente, nos tempos acima de 24 horas, uma considerável proporção das fibras e terminais nervosos devem 
estar sofrendo um adiantado processo de fagocitose por macrófagos, uma vez que o gânglio ótico está localizado muito próximo da ATM do rato. Logo, o sacrifício dos animais, 24 horas após ganglionectomia, parece ter sido adequado para nosso intuito.

A localização das fibras e terminais nervosos posicionados principalmente na parede de vasos sanguíneos arteriolares revela que o componente parassimpático está principalmente envolvido no controle vasomotor do segmento arteriolar, e consequentemente na homeostase articular, como por exemplo, na produção do líquido sinovial, como tem sido sugerido por outros estudos (ACKERMANN et al., 2001; KIDO et al., 2001). 


\section{CAPÍTULO 2}

Padrão de ativação neuronal no complexo nuclear trigeminal e no sistema endógeno de modulação da dor durante a vigência de monoartrite na articulação temporomandibular do rato 


\subsection{INTRODUÇÃO}

Acometendo mais de $12 \%$ da população, as desordens temporomandibulares (DTMs) consistem em um grupo heterogêneo de condições patológicas, que afetam a ATM e/ou os músculos da mastigação (VON KORFF et al., 1988; DWORKIN et al., 1990; CARLSSON e LE RESCHE, 1995). Uma considerável parcela das DTMs esta associada com inflamação articular, a qual após uma fase aguda, normalmente progride para uma fase crônica, sendo muito frequentes os episódios de agudização (KAMELCHUK e MAJOR, 1995; DONALDSON, 1995; TANAKA et al., 2008). A inflamação é uma das principais responsáveis pela iniciação e/ou manutenção da dor persistente nas DTMs, e ocasiona inúmeros efeitos subseqüentes, como hiperalgesia secundária, alodinia e dor heterotópica, o que sugere o envolvimento de mecanismos neurais centrais e periféricos (DENUCCl et al., 1996; SESSLE, 2000; SCHAIBLE et al., 2002; LOBBEZO et al., 2004; SUZUKI e DICKENSON, 2005). A exemplo disto, pacientes com DTMs exibem uma redução no limiar de excitação e maior somação temporal para dor experimental, o que faz com que alguns autores sugiram que ocorra uma redução na capacidade de recrutar o sistema endógeno de modulacão da dor (FILLINGIM et al., 1996; MAIXNER et al., 1995, MAIXNER et al., 1998; SVENSSON et al., 2001; BRAGDON et al., 2002), todavia são escassos e incompletos os trabalhos existentes na literatura científica para suportar tal suposição.

A ATM é um território densamente inervado por fibras nervosas sensitivas e autonômicas (ICHIKAWA et al., 1989; KIDO et al., 1993; MORANI et al., 1994; SHIMIZU, et al., 1996; SCHIMIDT et al., 1998; UDDMAN et al., 1998; HAEUCHI et al., 1999; YOSHIDA et al., 1999; KIDO et al., 2001). As fibras nervosas sensitivas, responsáveis pela inervação da ATM do rato, são originárias de neurônios sensoriais primários localizados, principalmente, no gânglio trigeminal (WIDENFALK e WIBERG, 1990; UDDMAN et al., 1998; YOSHINO et al., 1998; CASATTI et al., 1999). Tais fibras nervosas são predominantemente, dos tipos C e A $\delta$ (KIDO et al., 1995) e, terminam originando receptores sensoriais não encapsulados, que estão relacionados com o monitoramento nociceptivo desta articulação (KAWAMURA et al., 1967; KELLER e MOFFETT, 1968; GRIFFIN e HARRIS, 1975; WINK et al., 1992; 
KIDO et al., 1995). Os prolongamentos centrais destes neurônios convergem principalmente para o subnúcleo caudal do núcleo do trato espinal do nervo trigêmeo (Sp5C), uma das subdivisões do complexo nuclear trigeminal localizado no tronco encefálico (BEREITER et al., 2000; SESSLE, 2000). A informação nociceptiva que atinge o Sp5C está sujeita a modulação, efetuada por neurônios que constituem o sistema endógeno de modulação da dor (BASBAUM e FIELDS, 1984; CARTENS, 1987; FIELDS e BASBAUM, 1989; GEBHART e RANDICH, 1990; JONES, 1992).

$O$ circuito neural composto pela substância cinzenta periaqueductal- (PAG)área rostral ventromedial da medula oblonga (RVM)- Sp5C é uma parte do sistema endógeno de modulação da dor relativamente bem caracterizada (GEBHART, 1986; FIELDS et al., 1991; FIELDS e BASBAUM, 1999; MILLAN, 2002). No rato, a PAG envia fibras nervosas inibitórias diretamente para o Sp5C (MORGAN et al., 1997), ou indiretamente usando a RVM como uma estação intermediária (MORGAN et al., 1997, BEITZ et al.,1983). Os neurônios da RVM também podem emitir fibras nervosas para o Sp5C via neurônios localizados no locus coeruleus (LC), o grupamento A6 de células noradrenérgicas (KLATT et al., 1988; LI et al., 1993; TERHORST et al., 2001). Nas últimas décadas alguns trabalhos apontam outros territórios do tronco encefálico como atuantes na modulação da resposta nociceptiva e, os incorpora ao crescente sistema endógeno de modulação da dor (JANSS e GEBHART, 1988; JONES, 1992; TAVARES e LIMA, 1994; SUN e PANNETON, 2002; TAVARES e LIMA, 2002). O núcleo do trato solitário (NTS), a área caudal ventrolateral da medula oblonga (CVLM) e o núcleo reticular ventral (NRV), dentre outras funções, estão envolvidos na modulação da resposta nociceptiva, no entanto a atuação destes territórios tem sido muito explorada na medula espinal (TAVARES e LIMA, 1994; JANSS e GEBHART, 1988; SUN e PANNETON, 2002; TAVARES e LIMA, 2002) e raramente ao nível trigeminal (JONES, 1992). A estimulação elétrica da RVM, CVLM, NTS e NRV, durante experimentos que envolvem nocicepção, inibe a resposta comportamental a dor e a ativação de neurônios do Sp5C (JONES, 1992).

$O$ padrão de ativação neuronal tem sido amplamente utilizado para se estudar alterações em vias neurais extensas e complexas, como as supracitadas. A ativação de c-fos, um gene de expressão imediata, ou seu produto protéico, Fos, são 
empregados para mensurar a ativação neuronal decorrente dos mais variados estímulos (PRADO e DEL BEL, 1998; HARRIS, 1998; KOVACS, 1998). A maioria dos estudos utiliza Fos para verificar a ativação neuronal provocada por estímulo de curta duração e alta intensidade (LU et al., 1993; BEREITER et al., 1994; HATHAWAY et al., 1995; BEREITER et al., 2001; BEREITER et al., 2005). No entanto, a estimulação persistente, como inflamação periférica ou lesão neuropática, é capaz de promover expressão de Fos a longo prazo (ZHOU et al., 1999; PINTO et al., 2006; PINTO et al., 2007). No que se refere a ativação neuronal induzida por estímulo nociceptivo na ATM, estudos reportaram um aumento bilateral na expressão de Fos, no Sp5C, após monoartrite induzida neste complexo articular (HATHAWAY et al.,1995; ZHOU et al., 1999). Oh et al. (2006) verificaram um aumento na imunomarcação para Fos na RVM e LC, após injeção de formalina, no músculo masseter de ratos com dor crônica na ATM. A maneira pela qual o sistema endógeno de modulação da dor é ativado, durante a vigência de artrite na ATM, necessita de maior compreensão, especialmente quando episódios de agudização ocorrem em articulações sob vigência de artrite crônica, situação esta, também pouco explorada ao nível do complexo nuclear trigeminal.

O objetivo deste estudo foi determinar o padrão de ativação neuronal, através da expressão de Fos, no complexo nuclear trigeminal e, no sistema endógeno de modulação da dor, durante a vigência de monoartrite aguda, crônica ou crônica ativa no complexo articular temporomandibular (CATM) do rato. A monoartrite aguda e a crônica foram induzidas pela injeção, na ATM esquerda, de carragenina (CAR), 4 horas antes da eutanásia, no caso da primeira, e de adjuvante de Freund completo (CFA), 21 dias antes da eutanásia, para esta última. A monoartrite na fase crônica ativa se estabeleceu após uma primeira injeção de CFA na ATM esquerda, 21 dias antes da eutanásia e, uma injeção subsequente de CAR, pela mesma via de administração, 4 horas antes da eutanásia. 


\subsection{MATERIAL E MÉTODO}

Neste experimento foram utilizados 50 ratos machos (Rattus novergicus) da linhagem Wistar, adultos jovens, com 280 - 300g de peso corporal, obtidos no Biotério Central de Criação da Faculdade de Odontologia de Araçatuba da Universidade Estadual Paulista (FOA - UNESP). Os animais foram mantidos no Biotério de Experimentação da disciplina de Histologia e Embriologia da FOAUNESP sob as seguintes condições: ciclo de 12 horas de claro e 12 horas de escuro, temperatura ambiente de $22 \pm 2{ }^{\circ} \mathrm{C}$, sistema de ventilação/exaustão permitindo 20 trocas de ar por hora, umidade relativa do ar em torno de $55 \pm 5 \%$, acondicionamento em gaiolas plásticas (4 animais por gaiola), onde os animais tinham livre acesso ao alimento e a água. Foram tomadas todas as medidas cabíveis para se minimizar o número de animais utilizados, assim como evitar o seu sofrimento. Os procedimentos de manipulação experimental dos animais foram realizados de acordo com as normas estabelecidas no "Ethical guidelines for investigations of experimental pain in conscious animals" (ZIMMERMANN, 1983) e "Colégio Brasileiro de Experimentação Animal" (COBEA), e o protocolo experimental foi aprovado pela Comissão de Ética na Experimentação Animal da FOA - UNESP (certificado em anexo).

\subsubsection{Delineamento experimental}

\section{Protocolo de habituação dos animais}

Ao serem trazidos do Biotério Central de Criação para o Biotério de Experimentação todos os animais passaram por uma quarentena de acomodação, cuja principal finalidade era promover a sua familiarização com o ambiente. Logo após, estes animais foram submetidos a um protocolo de habituação, com o intutito de promover a sua familiarização com o operador e, minimizar o estresse provocado por algumas manobras de restrição. Tal protocolo compreendeu os 10 dias que antecederam o início do delineamento dos grupos, sendo que neste período cada animal foi suavemente manuseado entre as mãos do operador durante um intervalo 
de 5 minutos, no qual regularmente se aplicava uma manobra de restrição, simulando aquela necessária para se realizar a anestesia intramuscular.

\section{Anestesia}

Os animais foram anestesiados via uma injeção intramuscular de cloridrato de cetamina (10 mg/Kg, Francotar ${ }^{\circledR}$, Virbac, SP, Brasil) e cloridrato de xilazina $(1,4$ $\mathrm{mg} / \mathrm{kg}$, Rompum ${ }^{\circ}$, Bayer, RS, Brasil), a qual produziu um plano bastante superficial de anestesia, uma vez que a sua finalidade era apenas permitir a injeção intraarticular do agente pró-inflamatório ou da solução salina 0,9\%. A eleição destes agentes anestésicos se baseou na mínima interferência que apresentam sob a expressão de c-fos no sistema nervoso central (ROCHA e HERBERT, 1997; MAGDALENA et al., 2004).

\section{Monoartrite induzida experimentalmente no CATM}

Nós analisamos três diferentes fases da monoartrite induzida experimentalmente no CATM: aguda, crônica e crônica ativa. A monoartrite induzida experimentalmente foi provocada pela injeção intra-articular de adjuvante de Freund completo (CFA - Sigma, Saint Louis, MO, USA) (10 $\mu$, cada $\mu$ l de CFA é composto por $1 \mu \mathrm{g}$ de Mycobacterium tuberculosis, 0,85 $\mu$ de óleo de parafina e 0,15 $\mu$ de mono-oleato de manitol) e/ou de carragenina (CAR - Sigma, Saint Louis, MO, USA) (10 $\mu \mathrm{l}$, solução salina $0,9 \%$ acrescida de $10 \%$ de carragenina). Para a injeção do CFA e/ou da CAR na ATM o sítio de injeção foi identificado pela palpação do arco zigomático e côndilo da mandíbula. Uma agulha de calibre $30 \mathrm{G}$ (Becton Dickinson, São Paulo, SP, Brasil) acoplada a uma seringa microlitrada (Hamilton, Reno, NV, USA) foi inserida no ponto imediatamente inferior a borda póstero-inferior do arco zigomático, em seguida foi pressionada em sentido anterior até atingir a cavidade articular supradiscal da ATM esquerda. 


\section{Grupos controle e experimentais}

Depois de serem submetidos ao protocolo de habituação, os animais $(n=50)$ foram divididos em 10 grupos, cada um composto de 5 animais (Fig. 10):

- grupo controle total (CON TOT): cujos animais foram submetidos a eutanásia 21 dias após o término do protocolo de habituação.

- grupo controle anestésico 4 horas (ANES-4h): cujos animais foram apenas levemente anestesiados e, 4 horas depois foram submetidos a eutanásia.

- grupo controle salina 4 horas (SAL-4h): cujos animais, após serem levemente anestesiados, receberam a injeção intra-articular de $10 \mu$ solução salina 0,9\% (Sigma, Saint Louis, MO, USA) na ATM esquerda e, 4 horas depois foram submetidos a eutanásia.

- grupo ATM com artrite aguda (ART AG): cujos animais, após serem levemente anestesiados, receberam a injeção intra-articular de $10 \mu \mathrm{l}$ de CAR na ATM esquerda e, 4 horas depois foram submetidos a eutanásia.

grupo controle anestésico 21 dias (ANES-21d): cujos animais foram apenas levemente anestesiados e, 21 dias depois foram submetidos a eutanásia.

- grupo controle salina 21 dias (SAL-21d): cujos animais, após serem levemente anestesiados, receberam a injeção intra-articular de $10 \mu \mathrm{l}$ solução salina $0,9 \%$ na ATM esquerda e, 21 dias depois foram submetidos a eutanásia.

- grupo ATM com artrite crônica (ART CR): cujos animais, após serem levemente anestesiados, receberam a injeção intra-articular de $10 \mu \mathrm{l}$ de CFA na ATM esquerda e, 21 dias depois foram submetidos a eutanásia.

- grupo controle anestésico 21 dias e anestésico 4 horas (AN AN): cujos 
animais, por duas vezes, foram apenas levemente anestesiados, sendo que a primeira e a segunda anestesia precederam a eutanásia em 21 dias e 4 horas, respectivamente.

- grupo controle salina 21 dias e salina 4 horas (SAL SAL): cujos animais, após serem levemente anestesiados, receberam uma primeira e uma segunda injeção intra-articulare de $10 \mu$ s solução salina $0,9 \%$ na ATM esquerda, as quais precederam a eutanásia em 21 dias e 4 horas, respectivamente.

- grupo ATM com artrite crônica ativa (ART CR AT): cujos animais, após serem levemente anestesiados, receberam uma primeira injeção intra-articular de $10 \mu \mathrm{l}$ de CFA na ATM esquerda e, pela mesma via de administração, uma segunda injeção, agora de $10 \mu \mathrm{l}$ CAR. As injeções precederam a eutanásia em 21 dias, no caso da primeria e, 4 horas no caso da segunda.

Por uma questão de padronização, todos os procedimento descritos acima foram realizado no período da manhã, no intervalo compreendido entre 8 e 11 horas.

\section{Eutanásia}

Findado o desenho dos grupos controle e experimentais, os animais foram profundamente anestesiados, via injeção intramuscular de cloridrato de cetamina (100 mg/Kg, Francotar ${ }^{\circ}$, Virbac, SP, Brasil) e cloridrato de xilazina $(14 \mathrm{mg} / \mathrm{kg}$, Rompum ${ }^{\circledR}$, Bayer, RS, Brasil) e, submetidos a perfusão transcardíaca com solução salina $0,9 \%$ heparinizada $(100 \mathrm{ml})$, seguida de solução fixadora $(800 \mathrm{ml})$ constituída de $4 \%$ de formaldeído (Sigma, Saint Louis, MO, USA) em tampão tetraborato de sódio 3,8\% (Sigma, Saint Louis, MO, USA), 0,1M, $4^{\circ} \mathrm{C}, \mathrm{pH} 9,5$. Salientamos que tivemos a cautela de restringir o intervalo de tempo compreendido entre a anestesia e, o início da perfusão transcardíaca com a solução fixadora, a um perído inferior a 3 minutos, evitando assim a interferência deste procedimento operatório na expressão de Fos no sistema nervoso central. Os encéfalos e as ATMs foram cuidadosamente dissecados com auxílio de um microscópio estereoscópio cirúrgico (MCM5 - D. F. Vasconcellos S/A, São Paulo, SP, Brazil) e, submetidos 
a pós-fixação na mesma solução fixadora durante 6 horas. Todo este procedimento foi realizado no período da manhã, no intervalo compreendido entre 8 e 11 horas, para evitar possíveis variações na expressão de Fos decorrente do ritmo circardiano.

\subsubsection{Preparação das amostras submetidas a reação imunoistoquímica para detecção de Fos ou a coloração de NissI}

Encerrado o período de pós-fixação, os encéfalos foram crioprotegidos em solução contendo tampão fosfato de potássio - KPBS (Sigma, Saint Louis, MO, USA) $0,1 \mathrm{M}, \mathrm{pH} 7,4$ acrescida de $30 \%$ de sacarose (Sigma, Saint Louis, MO, USA) durante 12 horas. Em prosseguimento tais amostras foram seccionadas transversalmente em micrótomo de congelação (Jung SM2000R, Leica, Nussloch, Alemanha), com $25 \mu \mathrm{m}$ de espessura e, estocadas a $-20 \stackrel{\circ}{\circ} \mathrm{em}$ solução anticongelante. Uma em cada seis secções do encéfalo foi processada através da técnica da imunoperoxidase indireta para detecção da proteína Fos.

Os cortes histológicos foram submetidos às seguintes etapas, sob agitação constante a $4^{\circ} \mathrm{C}$ : três lavagens de 10 minutos em KPBS; inibição da peroxidase endógena em solução contendo KPBS, 0,15\% de Triton X-100 (Sigma, Saint Louis, MO, USA), 1\% de peróxido de hidrogênio (Sigma, Saint Louis, MO, USA), durante 30 minutos; três lavagens de 10 minutos cada em KPBS; bloqueio de sítios inespecíficos em solução contendo KPBS, $0,15 \%$ de Triton X-100 e 5\% de soro normal de burro (Vector Laboratories, Burlingame, CA, USA), durante 3 horas; incubação em anticorpo primário anti-Fos de rato gerado em coelho (1:5000; c-fos ab-5, Oncogene Research Products, San Diego, CA, USA), por 48 horas; três lavagens de 10 minutos em KPBS; incubação com anticorpo secundário biotinilado anti-IgG de coelho gerado em burro (1:200; Vector Laboratories, Burlingame, CA, USA), durante 90 minutos; três lavagens de 10 minutos em KPBS; incubação em solução de KPBS, $0,15 \%$ de triton X-100 e $0,8 \%$ do complexo avidina-biotina (Vecstain Elite ABC Kit, Vector Laboratories, Burlingame, CA, USA) por 90 minutos; três lavagens de 10 minutos em KPBS; incubação em solução contendo KPBS, 0,05\% 3, 3'- tetracloridrato de diaminobenzidina - DAB (Sigma, Saint Louis, MO, USA), $0,005 \%$ de peróxido de hidrogênio, e 1\% de sulfato de níquel amônio (NAS, 
Sigma, Saint Louis, MO, USA) durante 3 minutos; três lavagens de 10 minutos em KPBS. Os anticorpos foram diluídos em solução contendo KPBS, 0,15\% de triton X$100,2 \%$ de soro normal de burro. Na sequência, os cortes histológicos foram coletados em lâminas de vidro gelatinizadas, com auxílio de um microscópio estereoscópio cirúrgico, desidratados em etanol, diafanizados em xilol e, recobertos com meio de montagem (Permount, Fisher Scientific, San Diego, CA, USA) e lamínulas de vidro.

O controle negativo das reações imunoistoquímicas foi executado utilizadose o protocolo descrito anteriormente, todavia com a supressão do emprego do anticorpo primário.

Uma em cada seis secções do encéfalo, ou seja, a série de cortes histológicos imediatamente adjacente aquela submetida a técnica da imunoperoxidase para a deteção de Fos, foi processada segundo o método de coloração de Nissl, utilizando-se o corante tionina $0,25 \%$ e, examinada em microscópio óptico (Optiphot-2, NIKON, Japão), para proporcionar a definição dos limites e as devidas referências citoarquitetônicas das áreas a serem analisadas. 


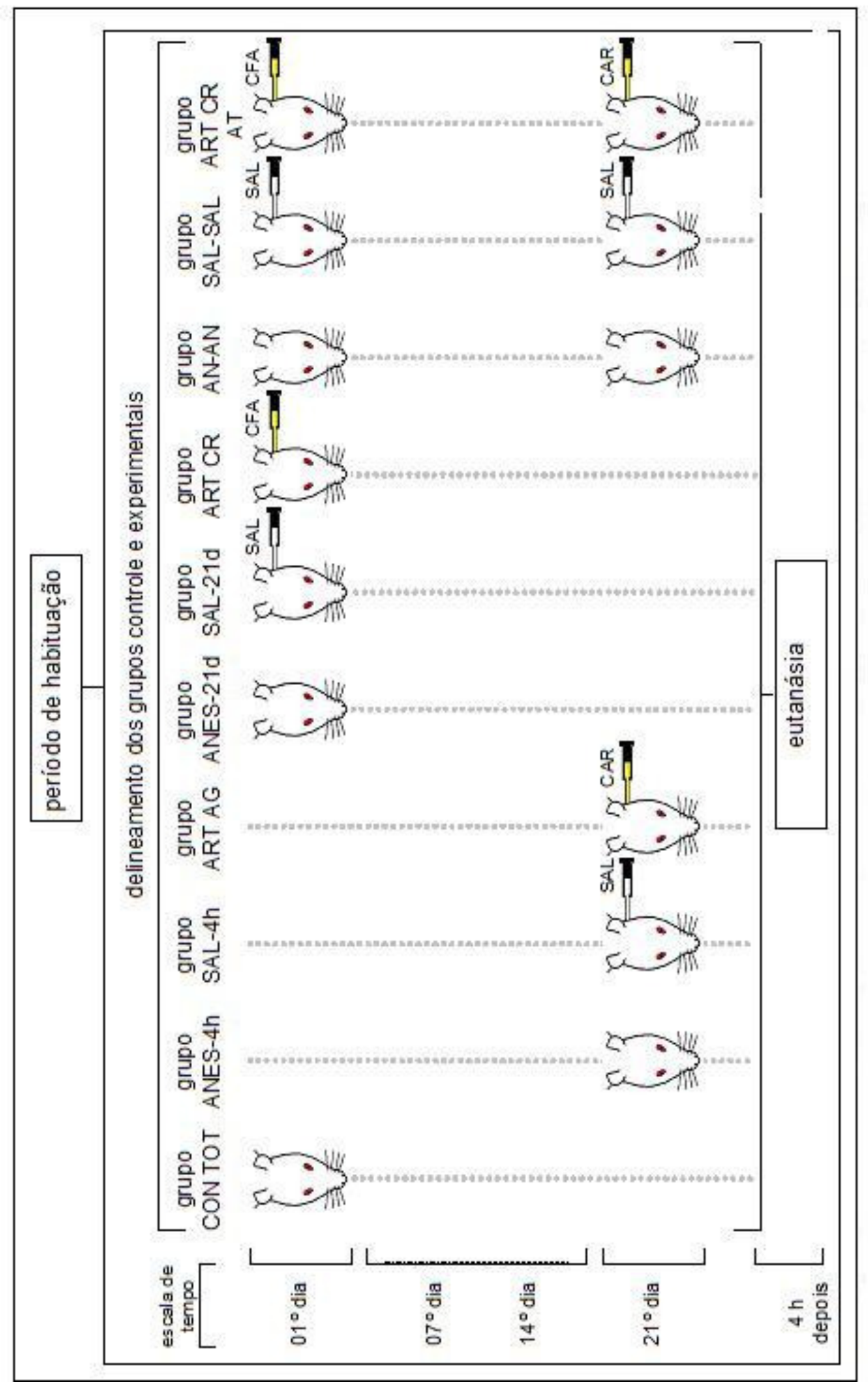

Figura 10. Esquema resumindo o delineamento experimental descrito em 2.2.1. Abreviações: SAL: salina 0,9\%; CAR: carragenina e; CFA: adjuvante de Freund completo. 


\subsubsection{Análise dos dados}

\section{Análise histológicas das amostras}

As secções foram analisadas sob iluminação de campo claro em microscópio óptico (Optiphot-2, NIKON, Japão) por um investigador que desconhecia os grupos controle ou experimentais que estavam sendo analisados. Inicialmente definiu-se como imunomarcação aquela de cor negra, com formato algo arredondo e cuja dimensão estivesse entre $8 \mu \mathrm{m}$ e $15 \mu \mathrm{m}$. Conforme citado anteriormente, um em cada seis cortes histológicos do encéfalo foi processado segundo a técnica da imunoperoxidade para a deteção de Fos, sendo assim, a distância entre cortes adjacentes era de $150 \mu \mathrm{m}$, o que nos assegurou que cada núcleo de neurônio marcado estava sendo contabilizado uma única vez. Por não condizer com o número absoluto de células imunomarcadas, empregamos a denominação preconizada por Coggeshall e Lekan (1996): perfil nuclear neuronal Fos- imunorreativo (Fos-IR), ou simplesmente, perfil de neurônios Fos-IR.

\section{Critérios de amostragem}

As áreas analisadas foram delineados de acordo com Paxinos e Watson (1998) em "The rat brain in stereotaxic coordinates" e, a série de cortes histológicos submetida a técnica de coloração de Nissl foi utilizada como referência citoarquitetônica. As seguintes áreas foram consideradas: o complexo nuclear trigeminal sensorial, o qual compreendeu os subnúcleos que compõem o núcleo do trato espinal do nervo trigêmeo (oral - Sp50, interpolar - Sp5I e caudal - Sp5C), o núcleo sensitivo principal do nervo trigêmeo (P5), o núcleo do trato mesencefálico do nervo trigêmeo (Me5); a RVM, que englobou o núcleo magno da rafe, o núcleo reticular gigantocelular adjacente e o núcleo paragigantocelular lateral; a CVLM, que compreendeu a formação reticular localizada medialmente ao núcleo do trato espinal do nervo trigêmeo, ventralmente ao núcleo ambíguo e lateralmente ao núcleo olivar inferior, incluindo o núcleo reticular lateral; o LC, o NTS, o NRV e a PAG.

Tais áreas foram capturados digitalmente mediante a utilização de uma câmera de vídeo CooISNAP-PRO (Media Cybernetics, Maryland, USA) 
simultaneamente acoplada a um microscópio óptico e um computador com programa de análise de imagens - Image Pro Plus v. 4.5 (Media Cybernetics, Maryland, USA). Devido a suas dimensões, algumas áreas foram capturadas aos segmentos e, foi necessário reconstruí-las encaixando cuidadosamente cada uma das imagens obtidas. Esta reconstrução, quando necessária, foi realizada utilizando-se o programa de desenho Adobe Photoshop 7.0.

Finalmente, na imagem processada cada perfil de neurônio Fos-IR foi manualmente registrado com uma marcação. Os valores obtidos após a análise quantitativa das áreas de interesse, nos diferentes grupos, foram expressos como média \pm erro padrão.

\section{Análise estatística}

Findada a análise quantitativa de perfis de neurônios Fos-IR no Sp5O, Sp5I, Sp5C, P5, Me5, RVM, CVLM, LC, NTS, NRV e PAG, estabelecemos uma comparação com seu correspondente nos diferentes grupos controle e experimentais, empregando o teste estatístico de Kruskal-Wallis. Este é um tipo de teste não paramétrico de análise de variância, onde não assumimos a premissa de que os nossos dados sigam uma distribuição normal. Ao utilizarmos este teste, verificamos a hipótese nula, que no caso do presente trabalho indicaria que a quantidade de perfis de neurônios Fos-IR se mostrava similar nos diferentes grupos, considerando-se cada uma das áreas analisadas e, a hipótese alternativa, segundo a qual, em cada uma das regiões analisadas, pelo menos um grupo apresentaria uma densidade de perfis de neurônios Fos-IR significativamente diferente dos demais. Uma vez constada a hipótese alternativa foi aplicado o teste pós-análise de variância de múltipla comparação de Dunn, considerando-se $p<0,05$ como sendo estatisticamente significante. 

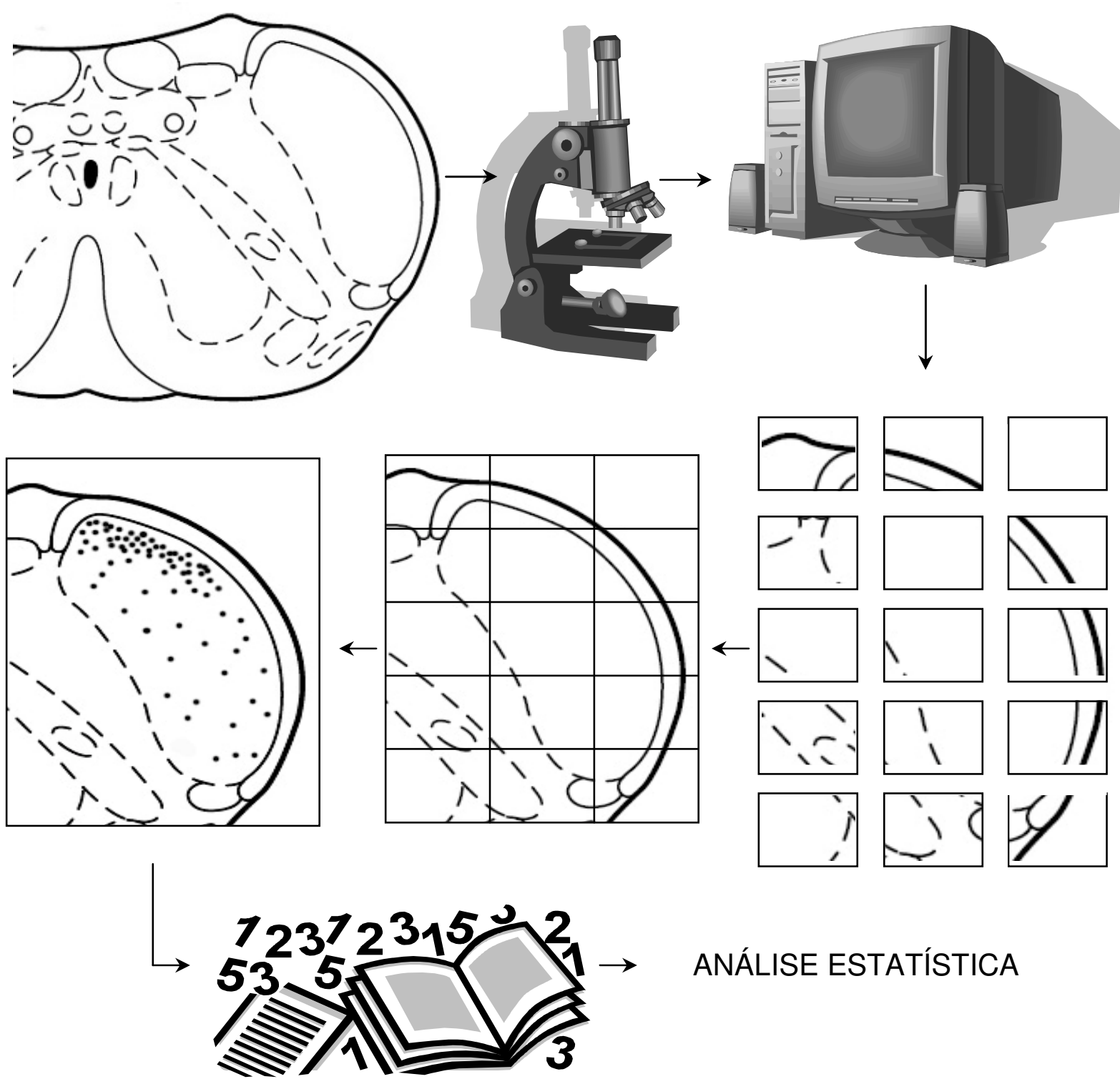

Figura 11. Esquema resumindo o procedimento de análise dos dados descrito em 2.2.3.

\subsubsection{Preparação das ATMs para exame histopatológico}

Ao término do período de pós-fixação, as ATMs ipsilaterais e contralaterais foram imersas em solução descalcificadora (constituída de KPBS acrescida de 10\% de EDTA, durante 30 dias à temperatura ambiente e sob agitação, com trocas da solução a cada dois dias). Em seguida foram processadas segundo técnica histológica de rotina (inclusão em parafina) e, os cortes histológico (5 $\mu \mathrm{m})$, corados com hematoxilina e eosina foram examinados em microscópio óptico. 


\subsection{RESULTADOS}

\subsubsection{Imunomarcação para Fos}

As imunomarcações se mostraram como estruturas arredondadas, de coloração negra, condizente com sua localização restrita ao núcleo celular. Para designar tais células marcadas utilizamos a denominação perfil nuclear neuronal Fos-imunorreativo (Fos-IR) ou perfil de neurônios Fos-IR.

A supressão do emprego do anticorpo primário resultou em ausência total de marcação, confirmando a especificidade da imunorreatividade observada, quando da utilização deste anticorpo.

\section{Imunomarcação para Fos no complexo nuclear trigeminal sensorial}

O padrão rostrocaudal de distribuição de perfis de neurônios Fos-IR no Sp5C, após monoartrite induzida no CATM, está apresentado na Fig. 13. No grupo CON TOT observamos uma pequena quantidade de perfis de neurônios Fos-IR difusamente distribuída ao longo do Sp5C (Fig. 12 e 13). Nos grupos cujos animais foram submetidos apenas a anestesia (ANES-4h, ANES-21d e AN/AN), não constatamos diferença estatisticamente significante na quantidade de perfis de neurônios marcados, quando os mesmos são comparados entre si. Da mesma forma, um padrão semelhante de imunomarcação foi constatado nos grupos que receberam apenas a injeção de solução salina 0,9\% na ATM esquerda (SAL-4h, SAL-21d e SAL/SAL). Diante destes dois últimos resultados, para uma melhor apreciação dos dados, todos os grupos que foram submetidos apenas a anestesia foram agrupados e coletivamente denominados de grupo controle anestésico (grupo ANES), enquanto aqueles que receberam apenas a injeção de solução salina $0,9 \%$ na ATM esquerda, constituíram um outro grande grupo chamado grupo controle salina (grupo SAL). Não houve diferença estatisticamente significante no número de perfis de neurônios imunomarcados entre os grupos CON TOT, ANES e SAL.

Constatou-se um aumento bilateral ( $p<0,001$, ipsilateral e $p<0,05$, 
contralateral) na quantidade de perfis de neurônios Fos-IR no Sp5C, predominantemente em suas lâminas superficiais, quando a ATM esquerda estava sob vigência de artrite na fase aguda (grupo ART AG) (Fig. 12 e 13). Todavia, quando a ATM esquerda estava sob vigência de artrite na fase crônica (ART CR) o aumento na quantidade de perfis de neurônios imunomarcados ficou confinado ao Sp5C ipsilateral $(p<0,05)$, sendo que a distribuição destas células se mostrou bimodal, ou seja, confinada a zona de transição do Sp5C com os segmentos C1 e C2 do corno dorsal da medula espinal $(\mathrm{Sp} 5 \mathrm{C} / \mathrm{C} 1, \mathrm{C} 2)(\mathrm{p}<0,05)$ e a zona de transição do Sp5C com o Sp5I (Sp5C/Sp5I) (Fig. 12 e 13). Quando se estabeleceu a comparação entre o grupo ART AG com o ART CR constatou-se, neste último, uma diminuição bilateral, estatisticamente significativa, na quantidade de perfis de neurônios imunomarcados (Fig. 13). Quando a ATM esquerda estava sob vigência de artrite na fase crônica ativa (grupo ART CR AT) constatamos um aumento bilateral ( $p<0,001$, ipsilateral e $p<0,05$, contralateral) no número de perfis de neurônios Fos-IR no Sp5C, cuja magnitude foi ainda maior que a apresentada pelo grupo ART AG, no entanto, quando comparado com este último, a significância estatística ficou confinada apenas ao lado contralateral ( $p<0,05$, contralateral) (Fig. 12 e 13). No grupo ART CR AT os perfis de neurônios Fos-IR do Sp5C se concentravam nas lâminas superficiais, no entanto, quando comparado com os demais grupos experimentais, este foi o grupo que apresentou a maior quantidade de perfis de neurônios marcados nas lâminas profundas deste subnúcleo.

Não houve imunorreatividade significativa, ou até mesmo se constatou ausência total de marcação, nos demais componentes do complexo sensitivo nuclear trigeminal, ou seja, Sp5O, P5 e Me5.

\section{Imunomarcação para Fos no sistema endógeno de modulação da dor localizado no tronco encefálico}

A análise da expressão de Fos foi realizada nos seis principais centros de modulação da dor localizados no tronco encefálico: PAG, RVM, CVLM, LC, NTS e NRV (Fig. 14 - 25). No grupo CON TOT verificamos uma pequena quantidade de perfis de neurônios Fos-IR em todos os centros de modulação da dor analisados 
(Fig. 14 - 25). Nos grupos cujos animais foram submetidos apenas a anestesia (ANES-4h, ANES-21d e AN/AN) não constatamos diferença estatisticamente significante na quantidade de perfis de neurônios marcados, quando os comparamos entre si. Um padrão semelhante de imunomarcação foi constatado nos grupos que receberam apenas a injeção de solução salina $0,9 \%$ na ATM esquerda (SAL-4h, SAL-21d e SAL/SAL). Semelhantemente ao que foi reportado anteriormente, para uma melhor apreciação dos dados, os grupos que foram submetidos apenas a anestesia e os grupos que receberam a injeção de solução salina $0,9 \%$ na ATM esquerda, foram denominados de grupo ANES e grupo SAL, respectivamente. Não foi constatada diferença estatisticamente significante no número perfis de neurônios Fos-IR nos centros de modulação da dor quando comparamos entre si os grupos CON TOT, ANES E SAL.

No grupo cuja ATM esquerda estava sob vigência de artrite na fase aguda (grupo ART AG) constatou-se um aumento bilateral estatisticamente significante na quantidade de perfis de neurônios Fos-IR na PAG ( $p<0,001$; Fig. 14 - 16), na RVM ( $p<0,001$, ipsilateral e $p<0,01$, contralateral; Fig. 17 e 18), na CVLM $(p<0,001$, ipsilateral e $p<0,01$, contralateral; Fig. 19 e 20), no LC ( $p<0,001$, ipsilateral e $p<0,01$, contralateral; Fig. 21 e 22) e no NTS ( $p<0,001$, ipsilateral e $p<0,01$, contralateral; Fig. 23 e 24), quando comparado com os grupos controle (grupos: CON TOT, ANES e SAL). No caso da RVM a maior densidade de perfis de neurônios imunomarcados foi observada no núcleo magno da rafe, enquanto que no CVLM uma grande quantidade de perfis de neurônios Fos-IR se concentrava em sua porção lateral, conhecida como CVLM lateral. Na PAG os perfis de neurônios Fos-IR foram encontrados em toda a sua extensão, com uma prevalência em sua porção ventrolateral, ao passo que no LC e no NTS esta distrubuição não mostrou preleção por algum território específico. No NRV a quantidade de perfis de neurônios Fos-IR sofreu um discreto aumento, no entanto não mostrou diferença estatisticamente significante quando comparado com os grupos controle (grupos: CON TOT, ANES e SAL - Fig. 25). No grupo cuja ATM esquerda estava sob vigência de artrite na fase crônica (ART CR) não foi constatada diferença estatisticamente significante na quantidade de perfis de neurônios Fos-IR nos centros de modulação da dor, quando o comparamos com os grupos controle (Fig. 17 - 25), exceto na PAG ( $p<0,05$, Fig. 
14 - 16), onde o aumento na quantidade de perfis de neurônios Fos-IR foi estatisticamente significante. Comparado com o grupo ART AG, a quantidade de perfis de neurônios Fos-IR foi significativamente menor no grupo ART CR, na PAG ( $p<0,05$; Fig. 14 - 16), na RVM ( $<<0,001$, ipsilateral e $p<0,05$, contralateral; Fig. 18), na CVLM ( $p<0,001$, ipsilateral e $p<0,01$, contralateral; Fig. 20), no LC $(p<0,01$, ipsilateral e $p<0,05$, contralateral; Fig. 22) e no NTS ( $p<0,001$, ipsilateral e $p<0,01$, contralateral; Fig. 24). No grupo cuja ATM esquerda estava sob vigência de artrite crônica ativa (ART CR AT) o aumento bilateral na quantidade de perfis de neurônios Fos-IR foi significante estatisticamente quando comparado com o grupo ART CR e com os grupos controle (CON TOT, ANES e SAL) e com o: na PAG $(p<0,001$, ipsilateral; Fig. 14 - 15), na RVM ( $p<0,001$, ipsilateral e $p<0,01$, contralateral; Fig. 17 e 18), na CVLM ( $p<0,001$, ipsilateral e $p<0,01$, contralateral; Fig. 19 e 20); no LC $(p<0,001$, ipsilateral e $p<0,01$, contralateral; Fig. 21 e 22) e no NTS $(p<0,001$, ipsilateral e $p<0,001$, contralateral; Fig. 23 e 24). O NRV apresentou um aumento na quantidade de perfis de neurônios Fos-IR, no entanto esta diferença não foi estatisticamente significante (Fig. 25). A quantidade perfis de neurônios imunomarcados em todos os centros de modulação da dor analisados no grupo ART CR AT foi maior que no grupo ART AG, no entanto esta diferença não se mostrou estatisticamente significante (Fig. 12 - 25).

\subsubsection{Análise histopatológica das ATMs}

As ATMs ipsilaterais pertencentes ao grupos CON TOT e ANES apresentaram um padrão histológico de normalidade, enquanto que aquelas pertencentes ao grupo SAL variavelmente mostraram pequenos e escassos focos de agrupamentos de células inflamatórias no tecido subsinovial, sem contudo caracterizar uma artrite. No grupo ART AG a injeção de carragenina, 4 horas antes da eutanásia, desencadeou um processo inflamatório articular tipicamente agudo, cujo infiltrado inflamatório, composto por neutrófilos e, alguns leucócitos mononucleados, estava localizado predominantemente no espaço articular supradiscal e, em toda a extensão do tecido conjuntivo sinovial e subsinovial (Fig. 26 A - B). No grupo ART CR a injeção de CFA, 21 dias antes da eutanásia, 
desencadeou um processo inflamatório articular tipicamente crônico, caracterizado pela presença de um moderado infiltrado inflamatório, constituído predominantemente de linfócitos e alguns plasmócitos e macrófagos, os quais foram observados por todo o tecido conjuntivo subsinovial. A camada íntima da membrana sinovial sofreu um espessamento considerável, enquanto que no espaço articular, notamos a presença de grande quantidade de vilosidades sinoviais, as quais são tipicamente encontradas em processos inflamatórios articulares crônicos (Fig. $26 \mathrm{C}$ D). No grupo ART CR AT uma primeira injeção intra-articular de CFA, 21 dias antes da eutanásia, provocou a instalação de um processo inflamatório que evoluiu para a cronificação, no entanto, a segunda injeção intra-articular de CAR, 4 horas antes da eutanásia, foi capaz de promover a agudização deste processo inflamatório, condizente com um quadro de artrite crônica ativa, onde um exuberante infiltrado inflamatório, constituído predominantemente por neutrófilos estava presente tanto no espaço articular quanto no tecido conjuntivo subsinovial. Algumas características típicas de artrite crônica ainda estavam presentes como a presença de linfócitos, macrófagos e escassos plasmócitos, assim como as vilosidades sinoviais (Fig. $26 \mathrm{E}$ - F). Importante ressaltar que o processo inflamatório ficou restrito a ATM, ou seja, os músculos, nervos, glândulas e a pele próximos desta articulação não foram afetados pelos agentes pró-inflamatórios. No que se refere às ATMs contralaterais, todos os grupos apresentaram um padrão histológico condizente com a condição de normalidade.

\subsubsection{Documentação fotográfica}




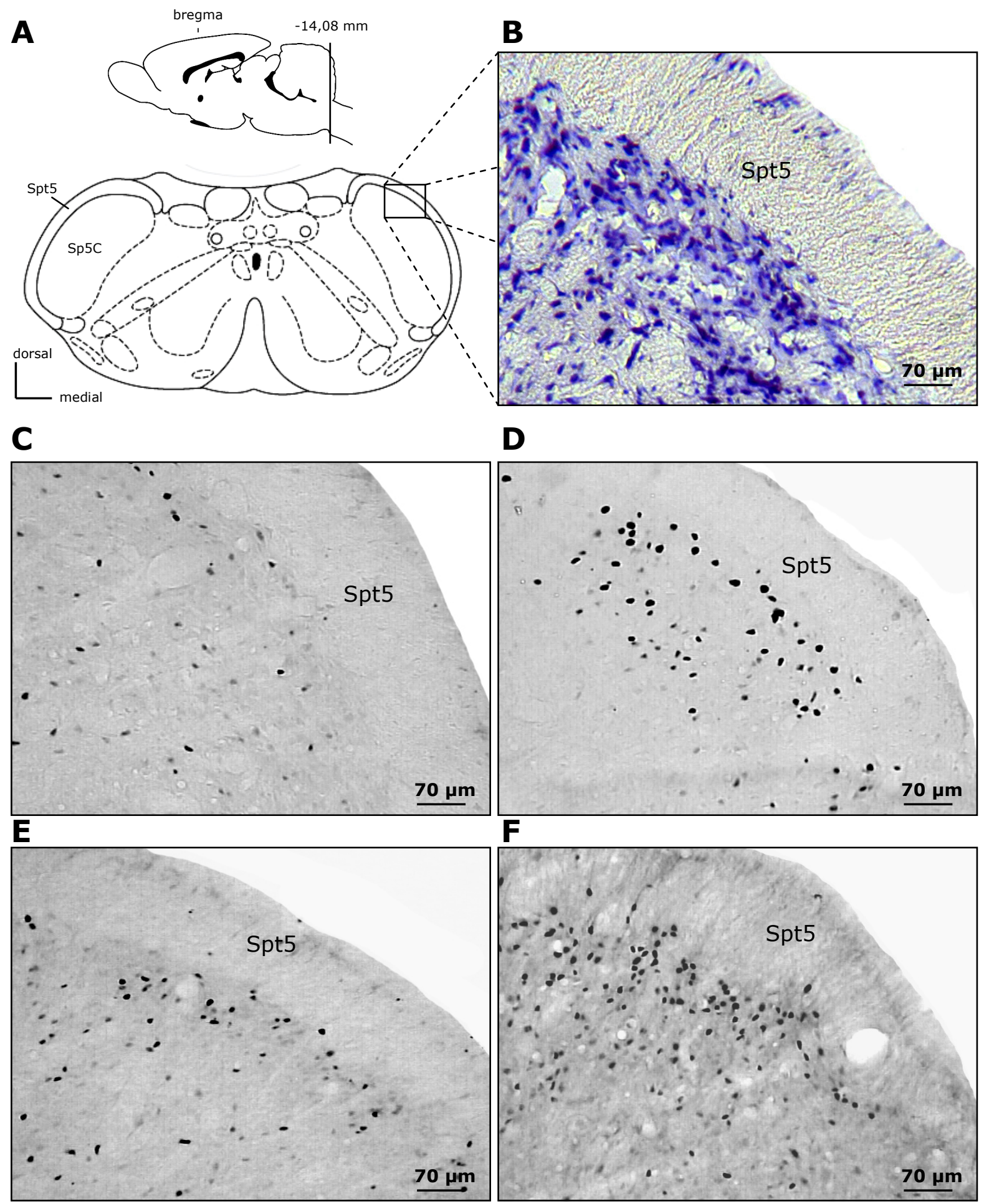

Figura 12. Imunomarcação para Fos no subnúcleo caudal do núcleo do tracto espinal do nervo trigêmeo (Sp5C) - lado ipsilateral. Em (A), representação esquemática de uma secção transversal do tronco encefálico do rato, em nível do Sp5C; em (B), fotomicrografia (microscopia de luz) do Sp5C corado pelo método de Nissl; de C - F, fotomicrografias (microscopia de luz) evidenciando o padrão de imunomarcação para Fos, no Sp5C de animais pertencentes aos grupos: CON TOT (C), ART AG (D), ART CR (E) e ART CR AT (F). Abreviações: Spt5: trato espinal do nervo trigêmeo. 


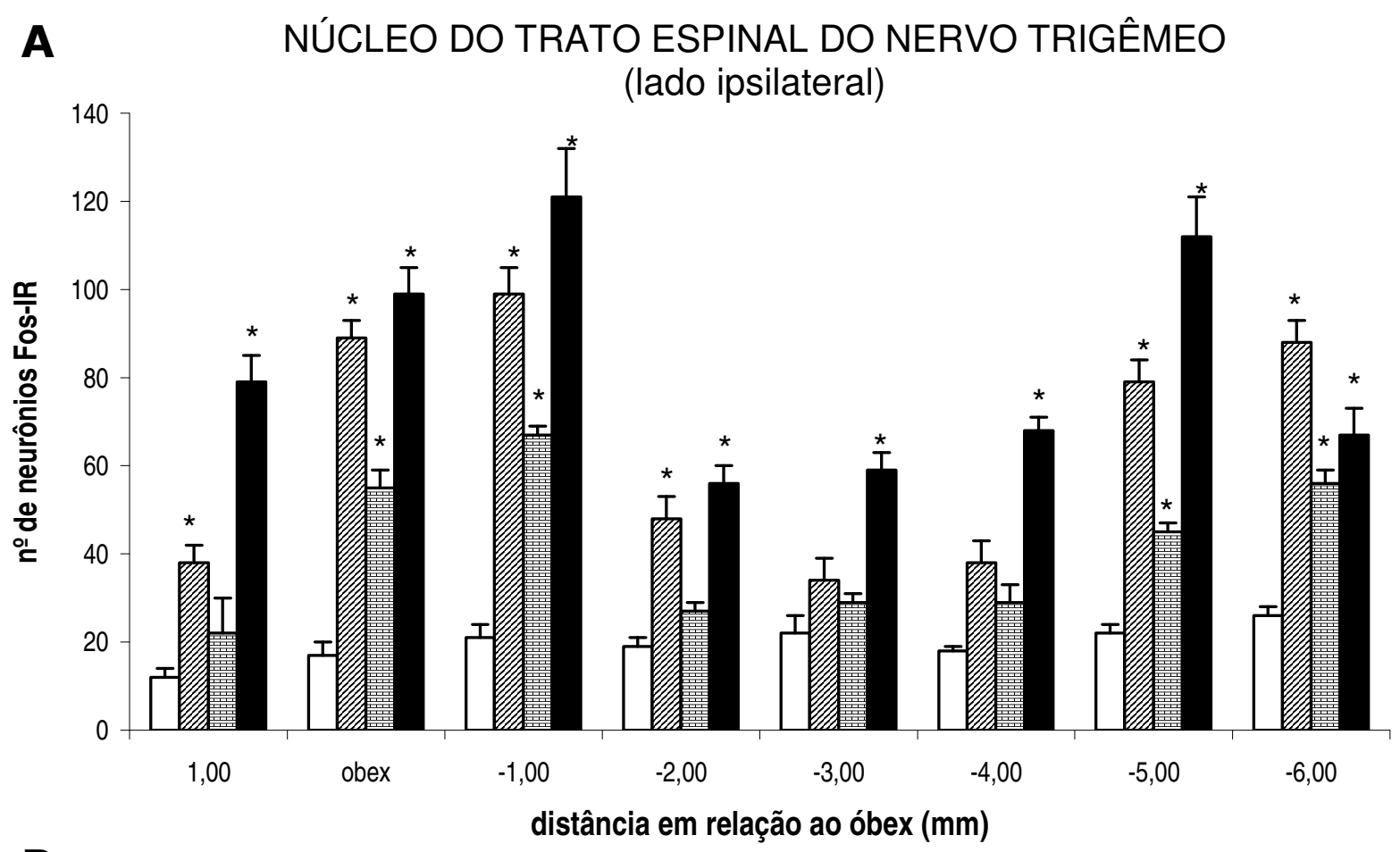

B

NÚCLEO DO TRATO ESPINAL DO NERVO TRIGÊMEO (lado contralateral)

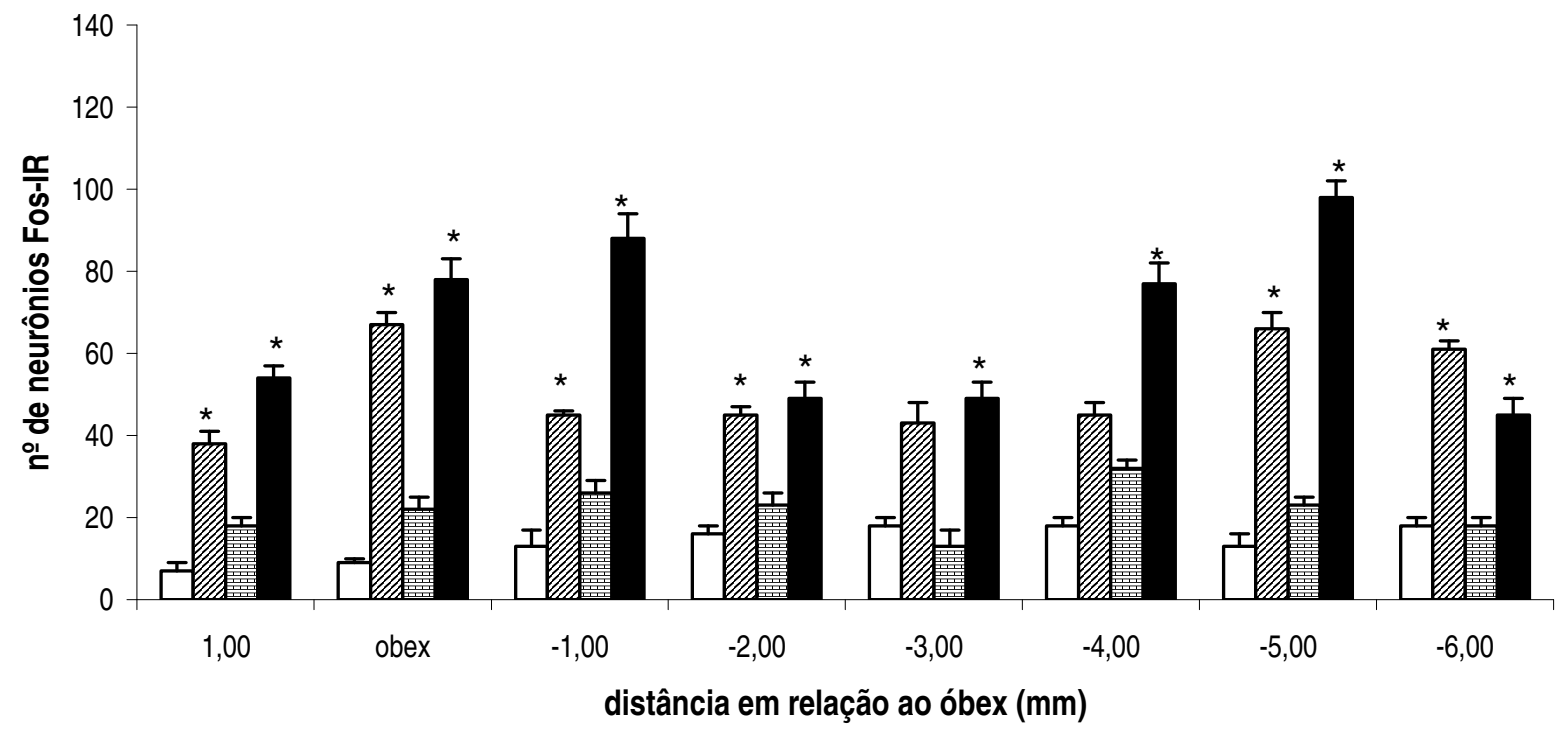

\section{$\square$ CON TOT}

四 ART AG

圆 ART CR

ART CR AT

Figura 13. Gráfico evidenciando o efeito da monoartrite no CATM (fases: aguda, crônica e crônica ativa) na expressão de Fos no Sp5C (A, lado ipsilateral; B, lado contralateral). Nos grupos controle e experimentais observamos a média \pm erro padrão do número total de perfis de neurônios Fos-IR quantificados em duas secções analisadas (ordenadas) e, sua distribuição rostro-caudal ao longo do Sp5C (abscissas), tomando-se o óbex como ponto de referência.

* indica diferença estatisticamente significante em relação ao grupo CON TOT. 
SUBSTÂNCIA CINZENTA PERIAQUEDUCTAL (PAG)

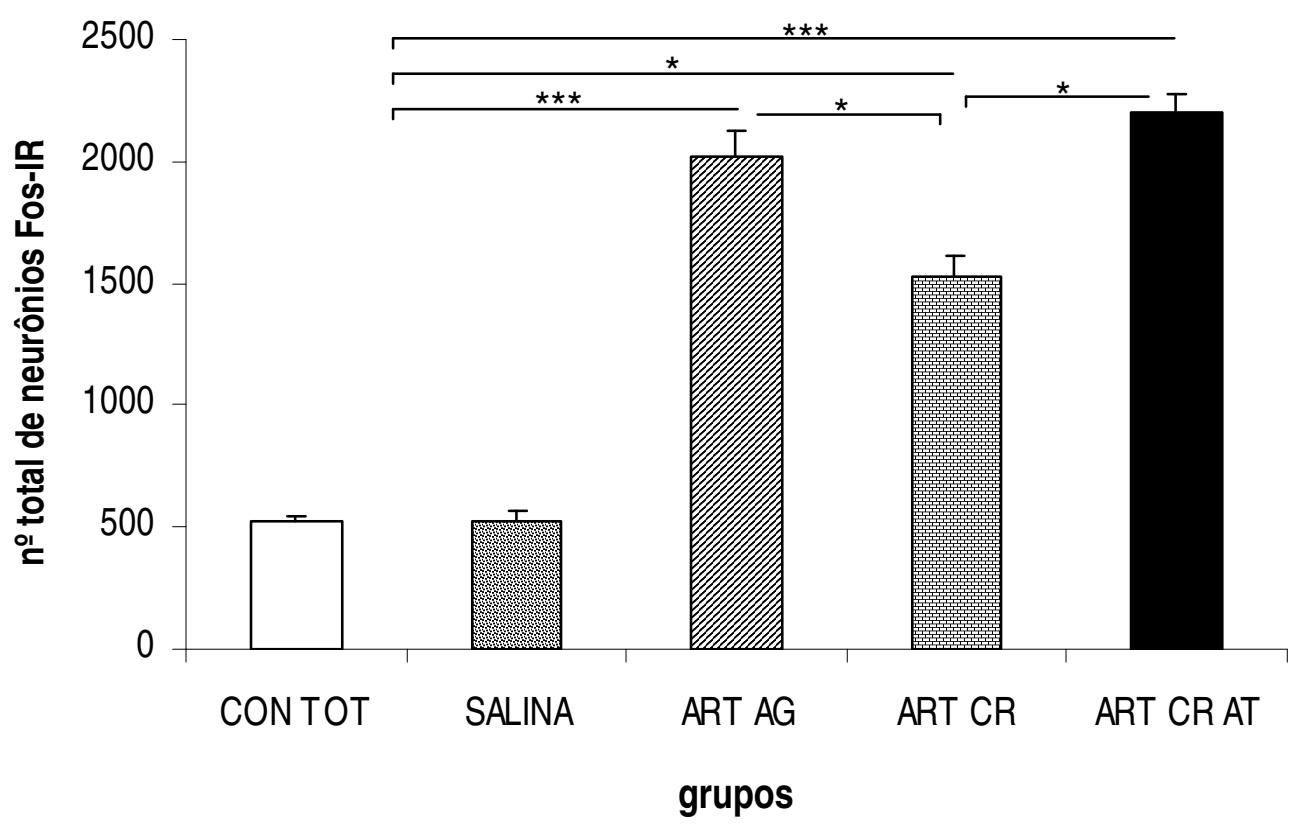

Figura 14. Gráfico evidenciando o efeito da monoartrite no CATM (fases: aguda, crônica e crônica ativa) na expressão de Fos na PAG. Média \pm erro padrão do número total de perfis de neurônios Fos-IR quantificados nas secções analisadas (ordenadas) nos diferentes grupos (abcissas). ${ }^{*} P<0,05$, indica diferença estatisticamente significante; ${ }^{* *} P<0,01$, indica diferença estatisticamente muito significante; ${ }^{* * *} P<0,001$, indica diferença estatística extremamente siqnificante.

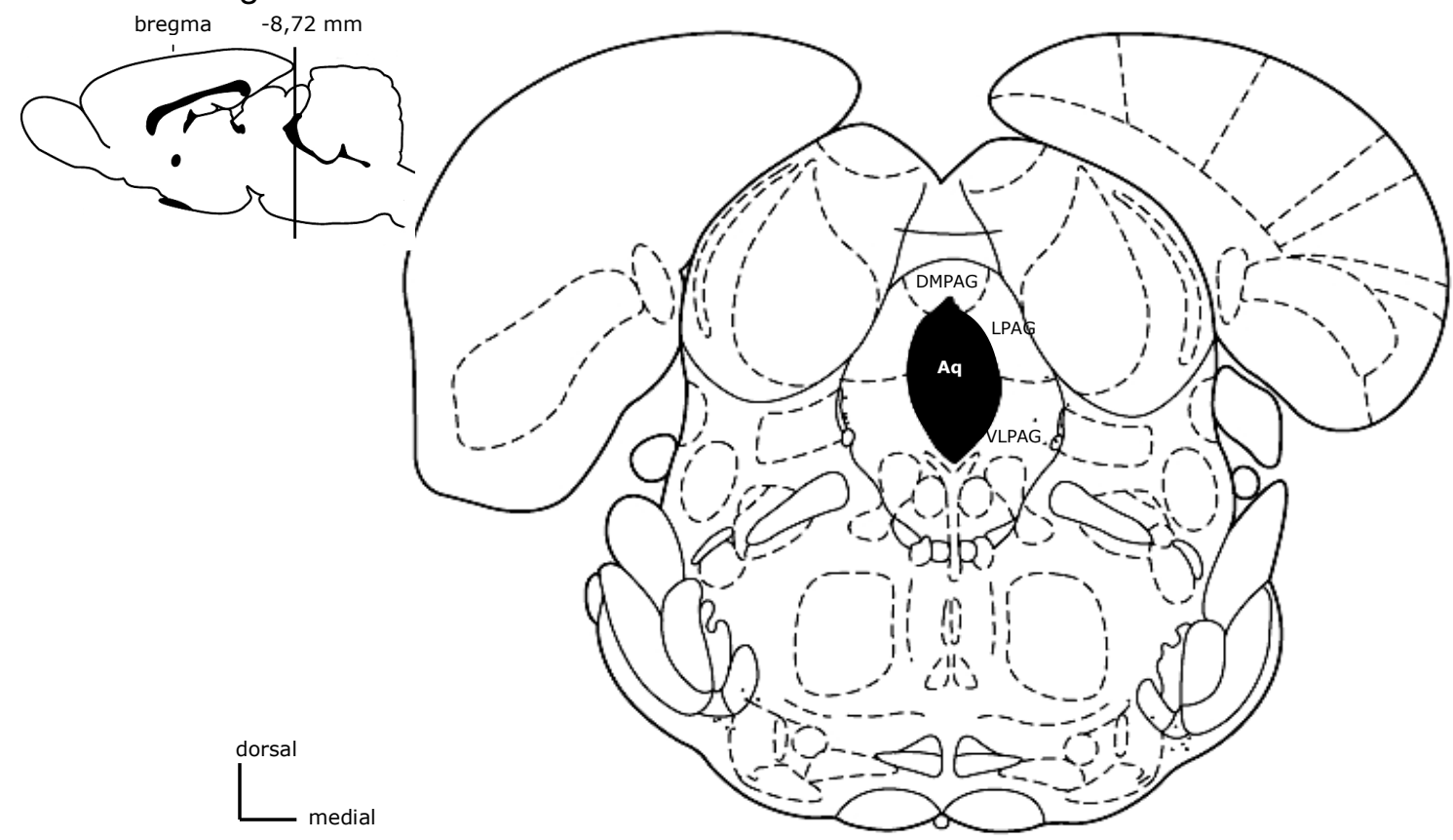

Figura 15. Representação esquemática de uma secção transversal do tronco encefálico do rato, em nível da PAG, a qual está individualizada na fig. 16. Abreviações: Aq: aqueduto cerebral; DMPAG: PAG dorsomedial; LPAG: PAG lateral; VLPAG: PAG ventrolateral. 
A

B

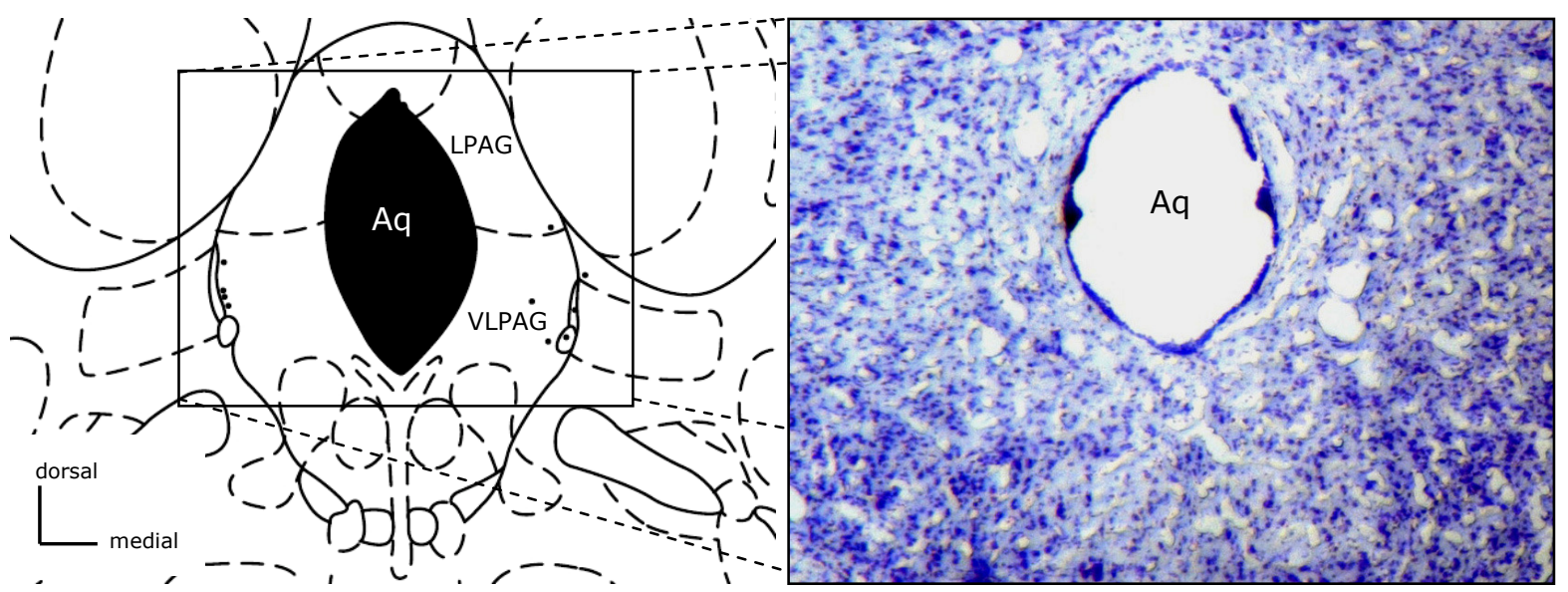

C

D
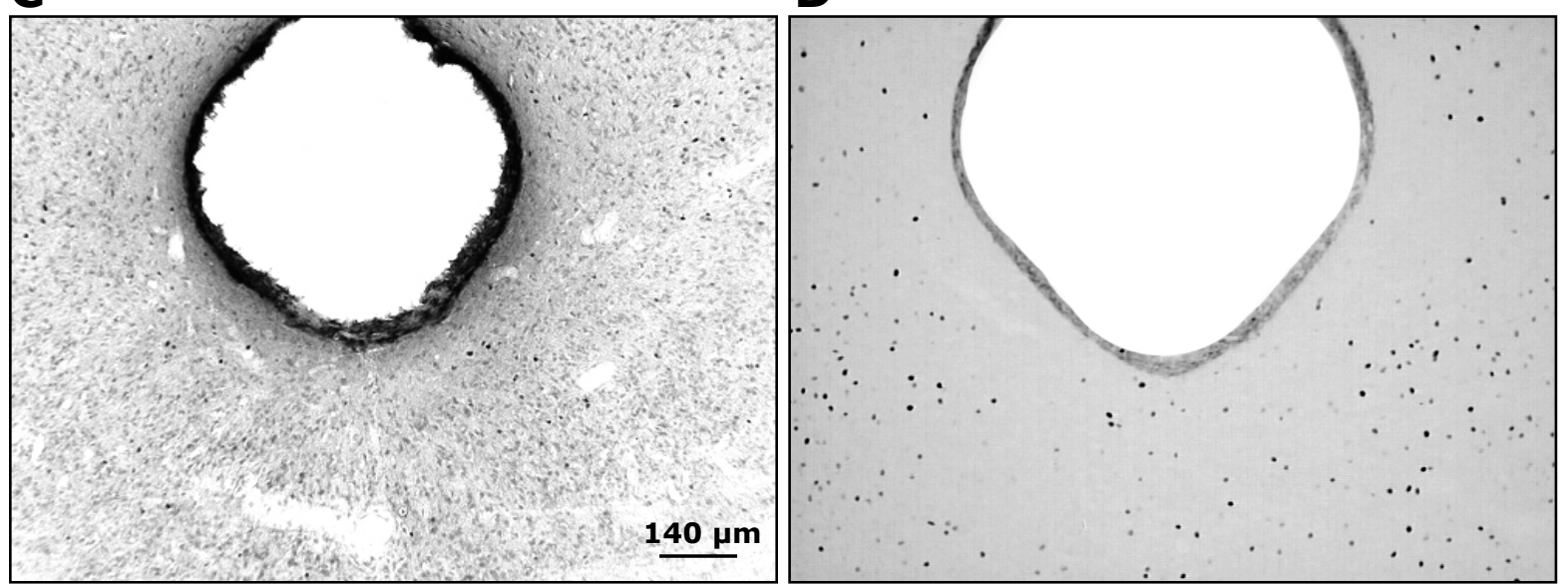

$\mathbf{E}$
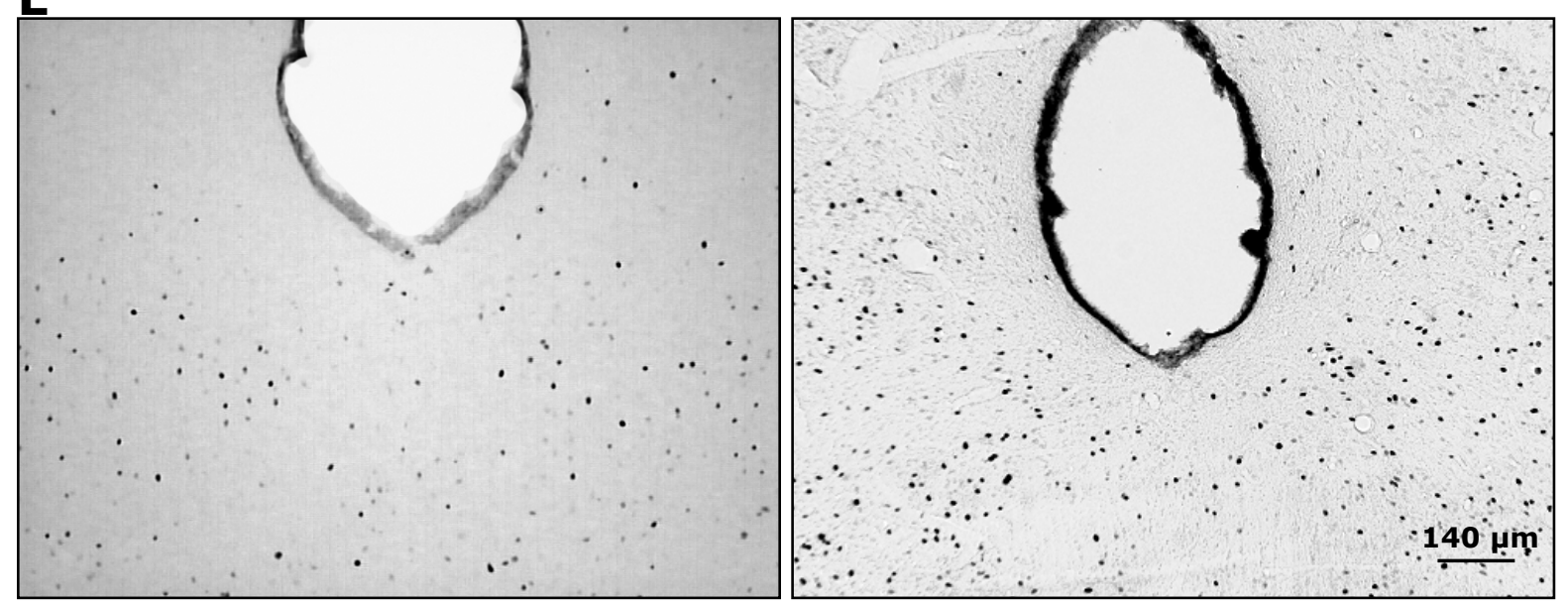

Figura 16. Imunomarcação para Fos na substância cinzenta periaqueductal (PAG). Em (A), representação esquemática de uma secção transversal do tronco encefálico do rato, em nível da PAG; em (B), fotomicrografia (microscopia de luz) da PAG corada pelo método de Nissl; de C - F, fotomicrografias (microscopia de luz) evidenciando o padrão de imunomarcação para Fos, na PAG de animais pertencentes aos grupos: CON TOT (C), ART AG (D), ART CR, (E) e ART CR AT(F). Abreviações: Aq: aqueduto cerebral; LPAG: PAG lateral; VLPAG: PAG ventrolateral. 


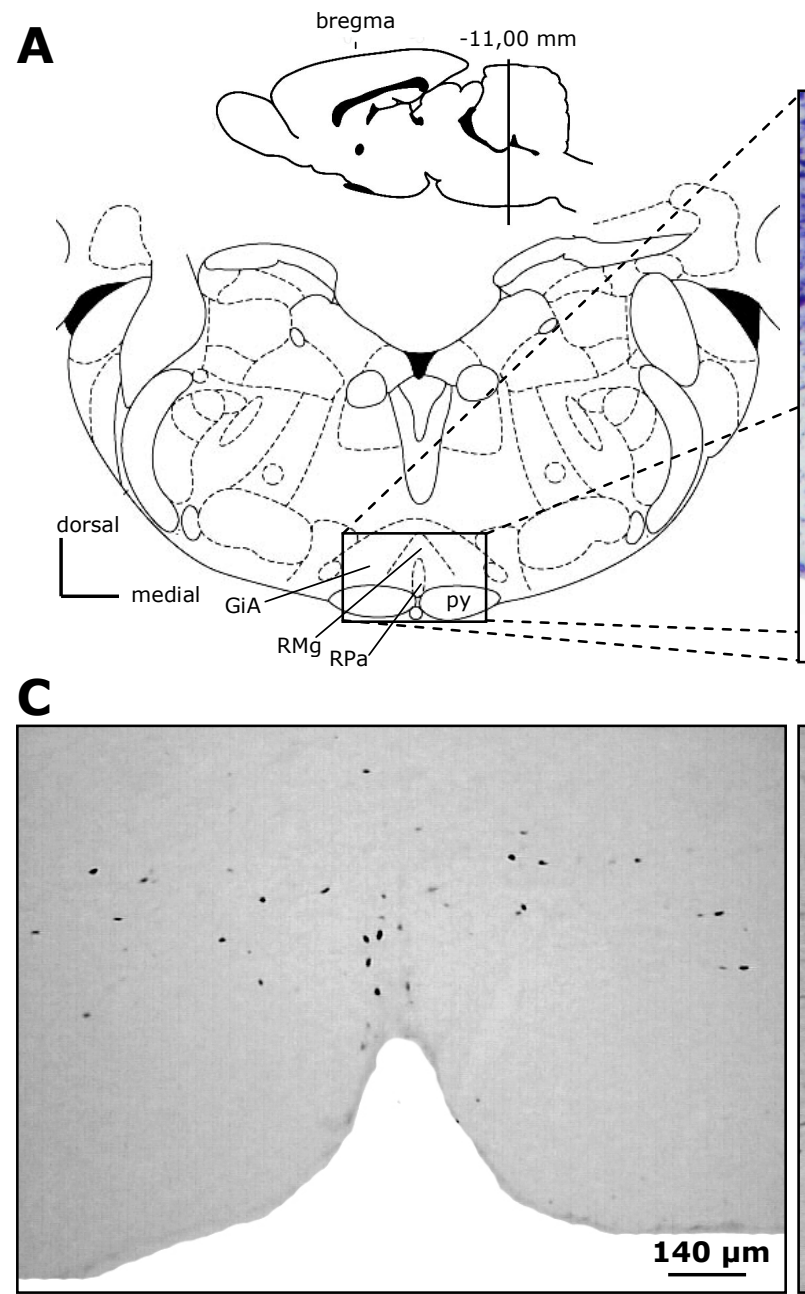

B

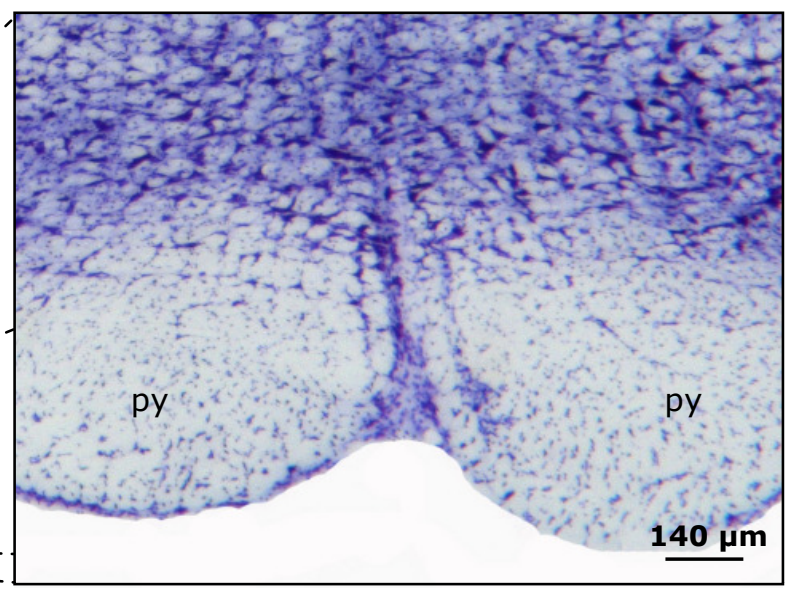

D

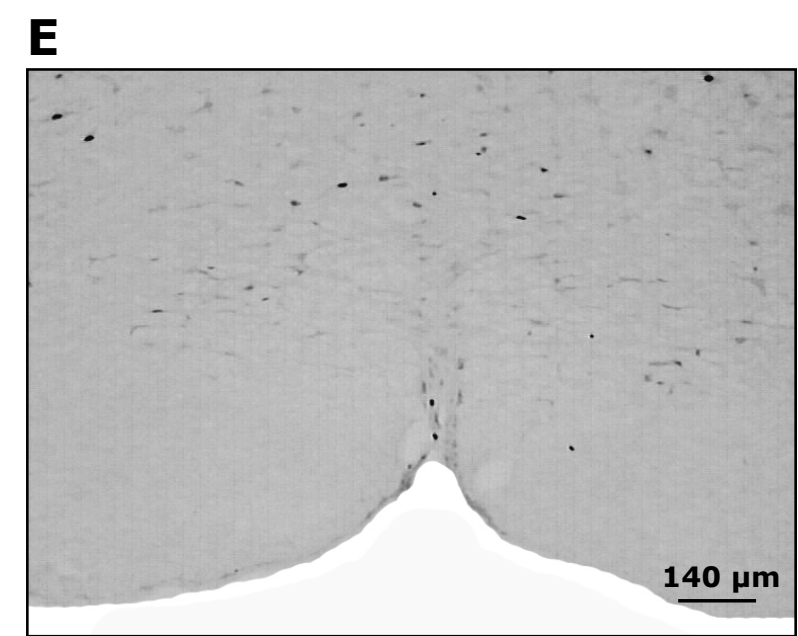

$\mathbf{F}$

$140 \mu \mathrm{m}$

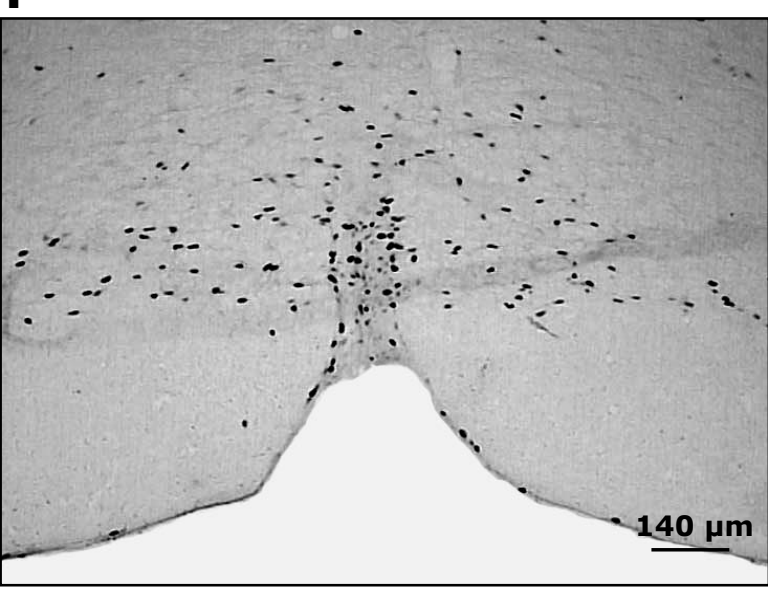

Figura 17. Imunomarcação para Fos na área rostral ventromedial da medula oblonga $(R V M)$. Em (A), representação esquemática de uma secção transversal do tronco encefálico do rato, em nível da RVM; em (B), fotomicrografia (microscopia de luz) da RVM corada pelo método de Nissl; de C - F, fotomicrografias (microscopia de luz) evidenciando o padrão de imunomarcação para Fos, na RVM de animais pertencentes aos grupos: CON TOT (C), ART AG (D), ART CR, (E) e ART CR AT(F). Abreviações: GiA: núcleo reticular gigantocelular, alfa; RMg: núcleo magno da rafe; RPa: núcleo pálido da rafe; py: trato piramidal. 
A

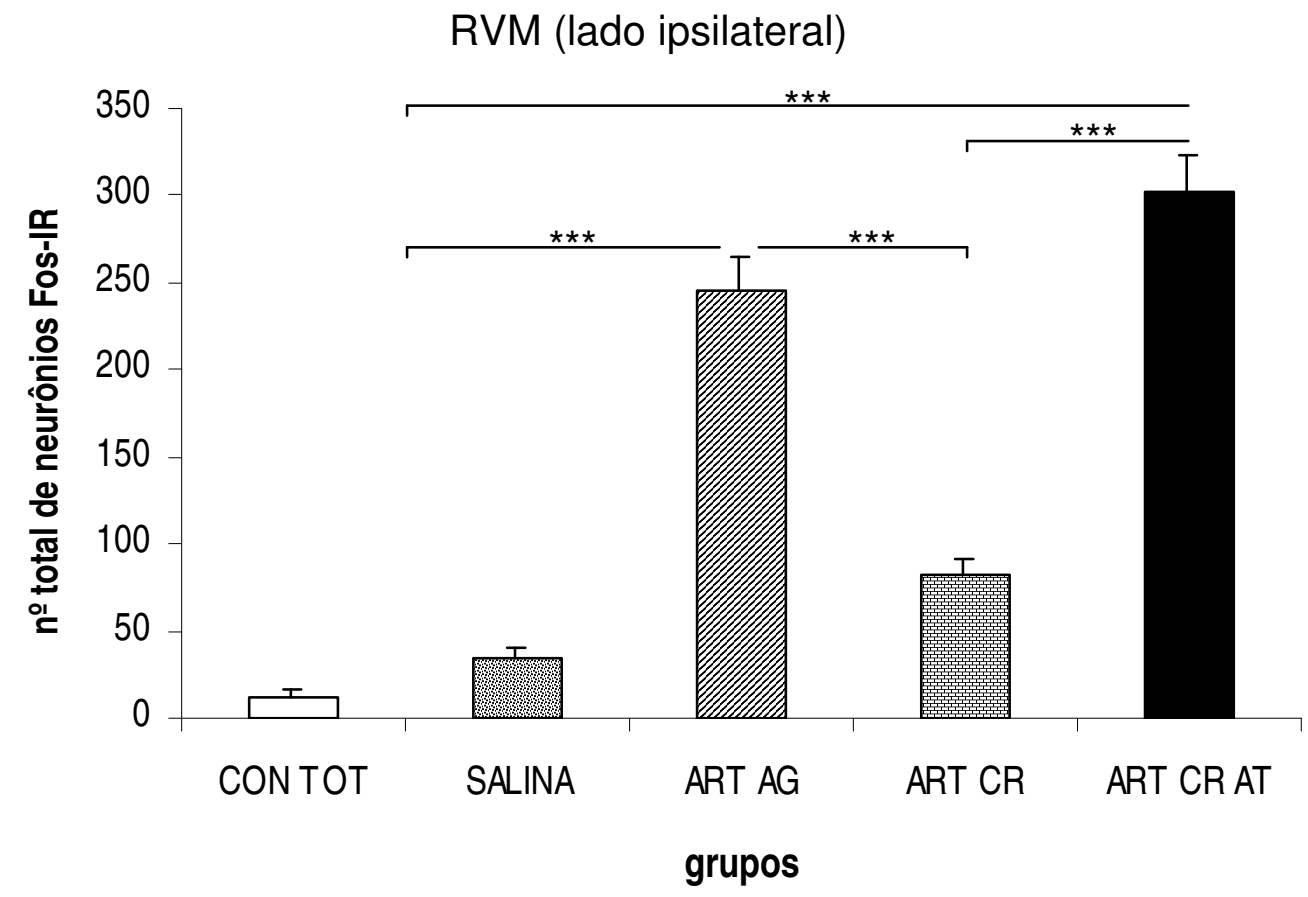

B

RVM (lado contralateral)

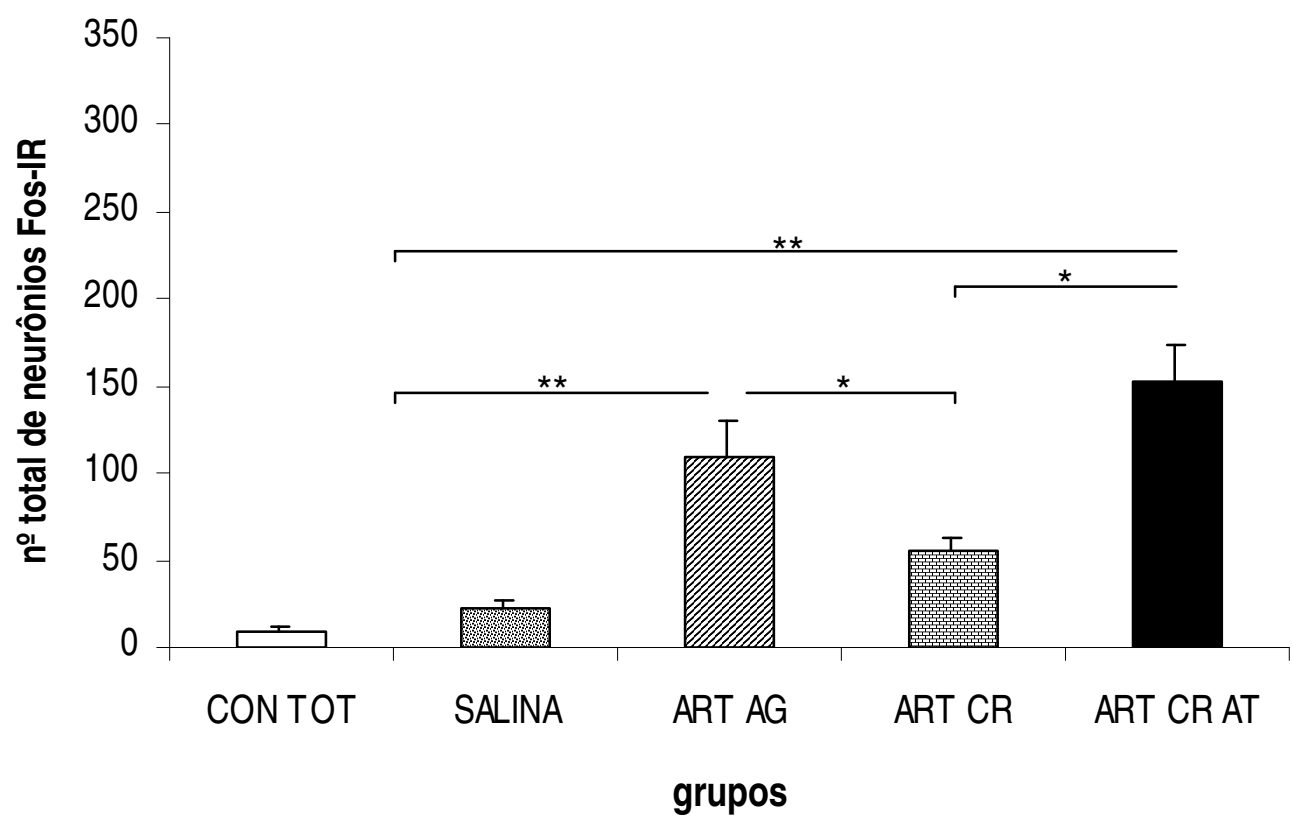

Figura 18. Gráfico evidenciando o efeito da monoartrite no CATM (fases: aguda, crônica e crônica ativa) na expressão de Fos na RVM do lado ipsilateral (A) e do lado contralateral $(B)$. Média \pm erro padrão do número total de perfis de neurônios Fos-IR quantificados nas secções analisadas (ordenadas) nos diferentes grupos (abcissas). ${ }^{*} P<0,05$, indica diferença estatisticamente significante; ${ }^{* *} P<0,01$, indica diferença estatisticamente muito significante; ${ }^{\star \star *} P<0,001$, indica diferença estatística extremamente significante. 
A

A bregma B

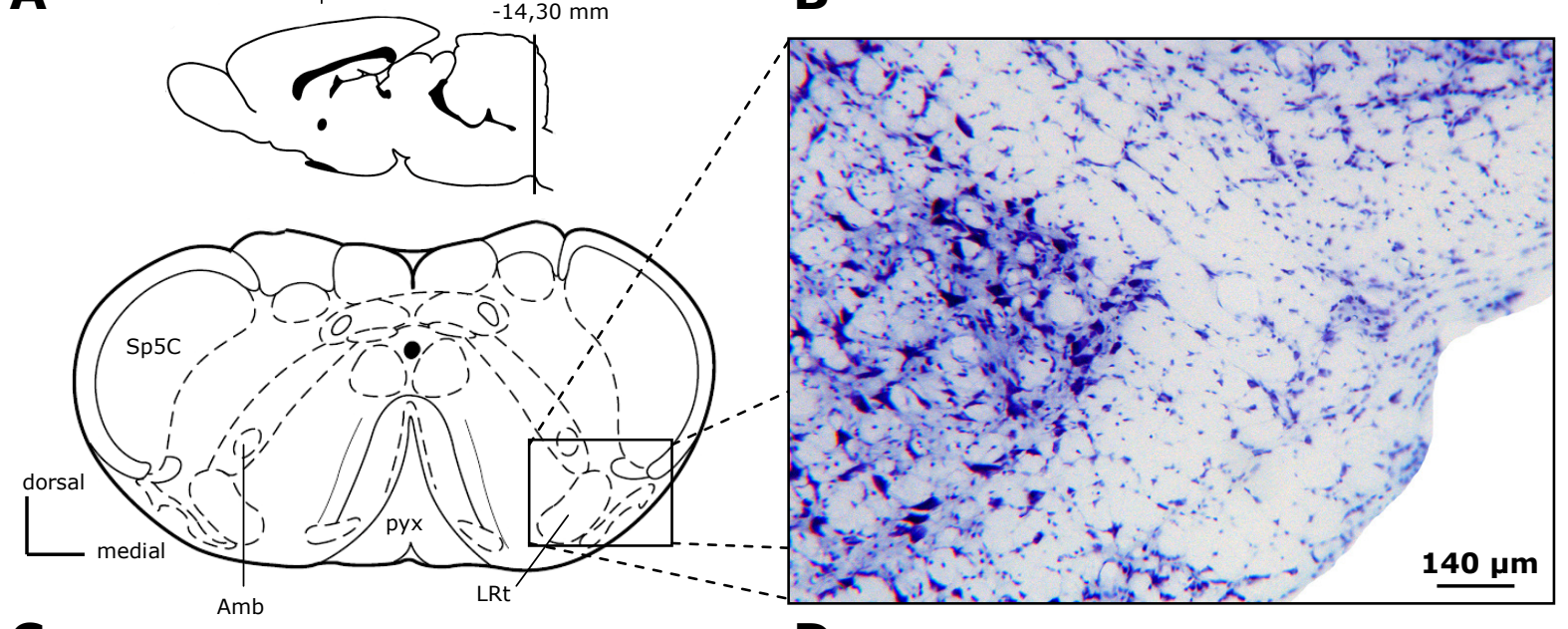

C

D
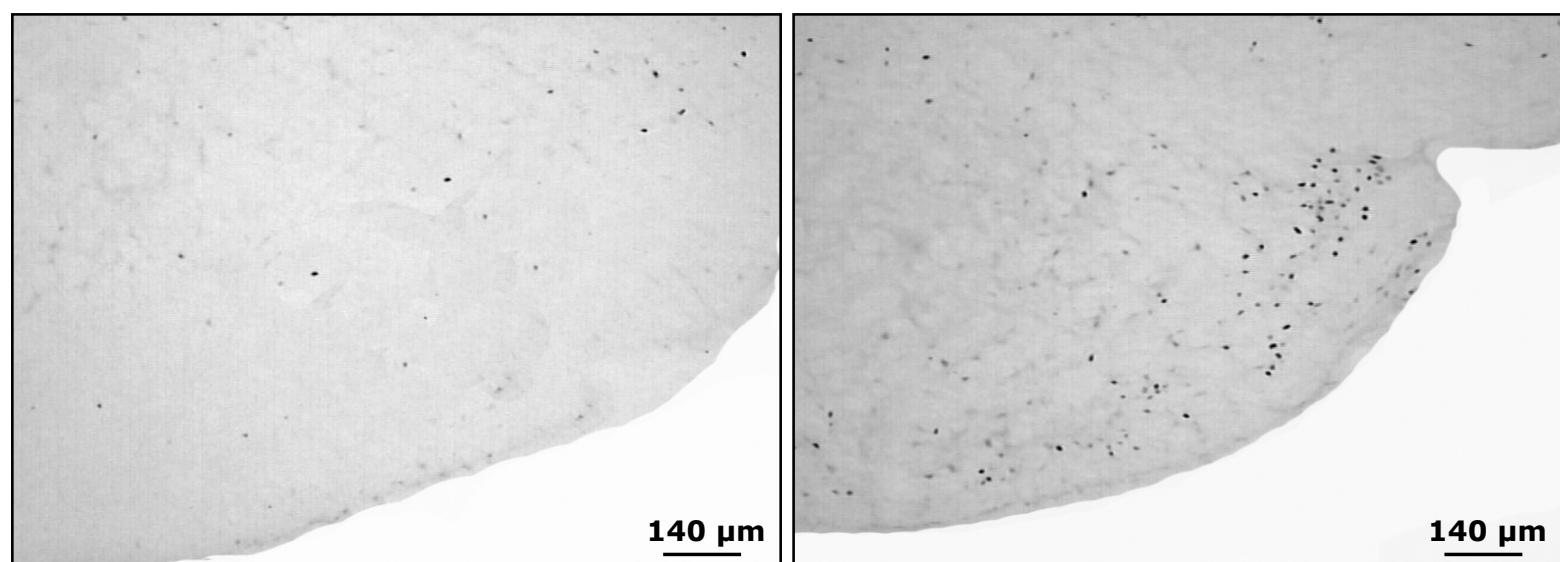

$\mathbf{E}$

$\mathbf{F}$
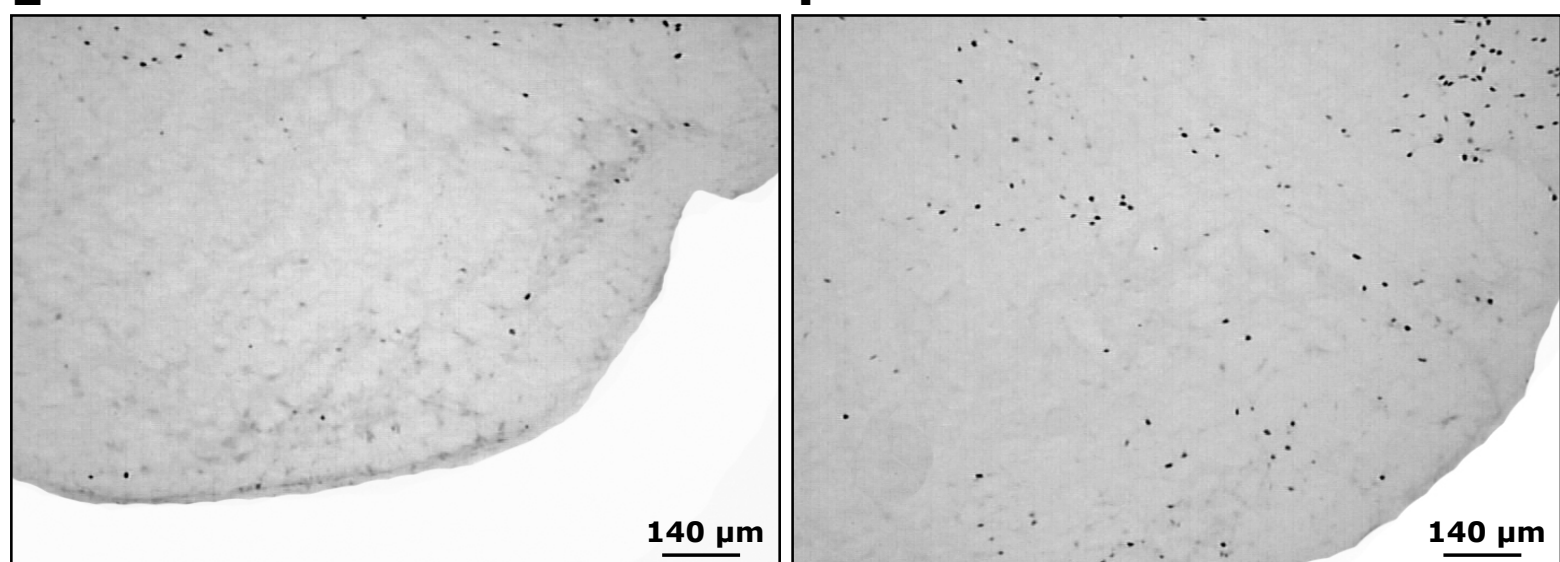

Figura 19. Imunomarcação para Fos na área caudal ventrolateral da medula oblonga (CVLM). Em (A), representação esquemática de uma secção transversal do tronco encefálico do rato, em nível da CVLM; em (B), fotomicrografia (microscopia de luz) da CVLM corada pelo método de Nissl; de C - F, fotomicrografias (microscopia de luz) evidenciando o padrão de imunomarcação para Fos, na CVLM de animais pertencentes aos grupos: CON TOT (C), ART AG (D), ART CR (E) e ART CR AT (F). Abreviações: Amb: núcleo ambíguo; LRt: núcleo reticular lateral; pyx: decussação piramidal; Sp5C: subnúcleo caudal do núcleo do trato espinal do nervo trigêmeo. 
A

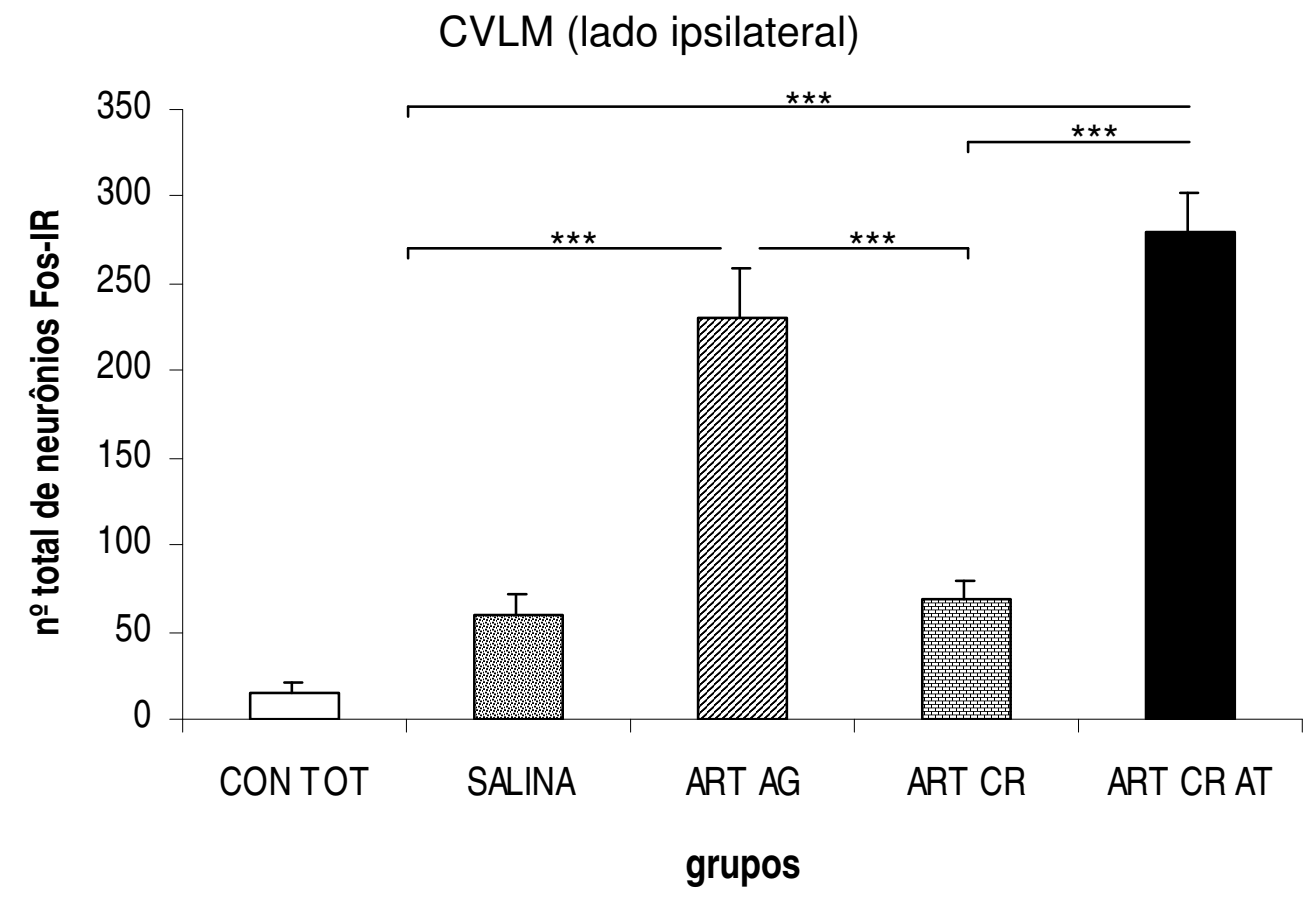

B

CVLM (lado contralateral)

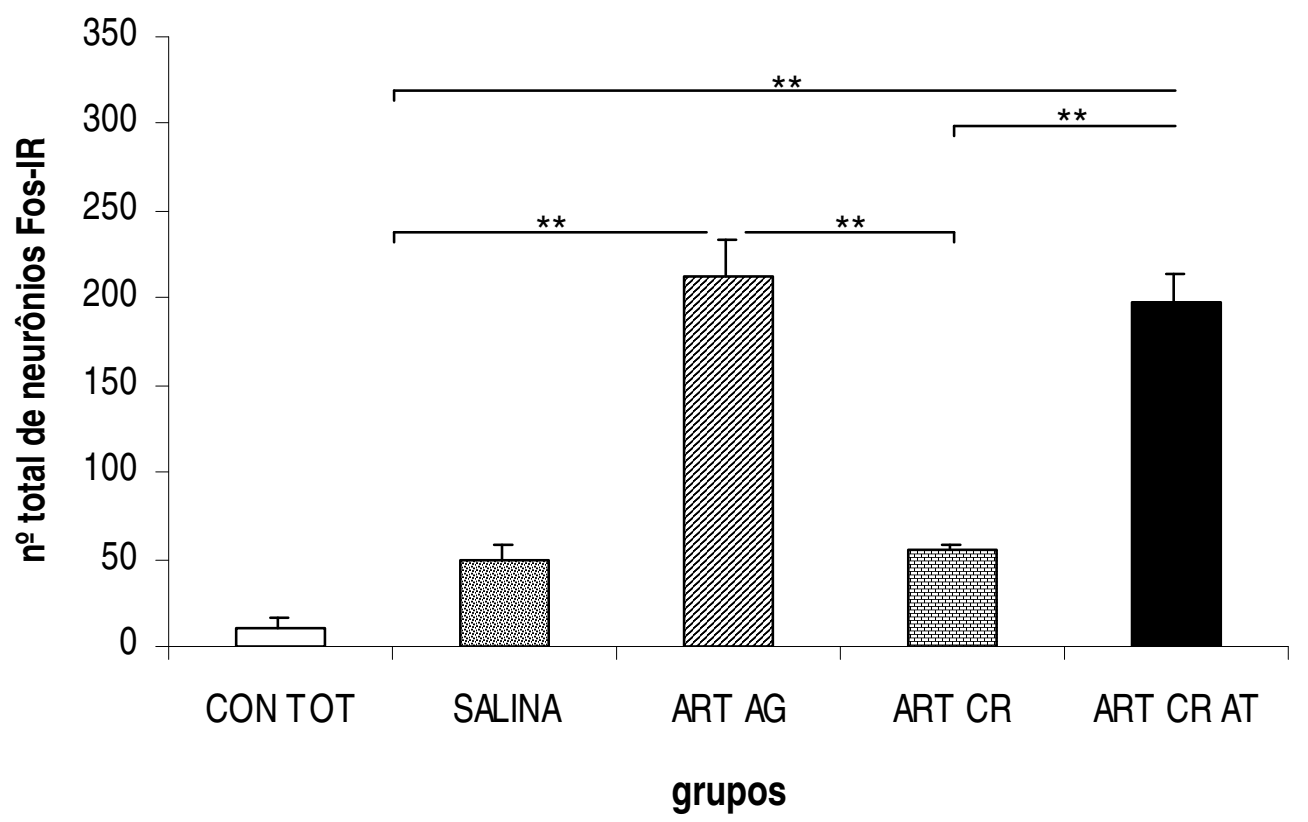

Figura 20. Gráfico evidenciando o efeito da monoartrite no CATM (fases: aguda, crônica e crônica ativa) na expressão de Fos na CVLM do lado ipsilateral (A) e do lado contralateral $(B)$. Média \pm erro padrão do número total de perfis de neurônios Fos-IR quantificados nas secções analisadas (ordenadas) nos diferentes grupos (abcissas). ${ }^{*} P<0,05$, indica diferença estatisticamente significante; ${ }^{* *} P<0,01$, indica diferença estatisticamente muito significante; ${ }^{* * *} P<0,001$, indica diferença estatística extremamente significante. 


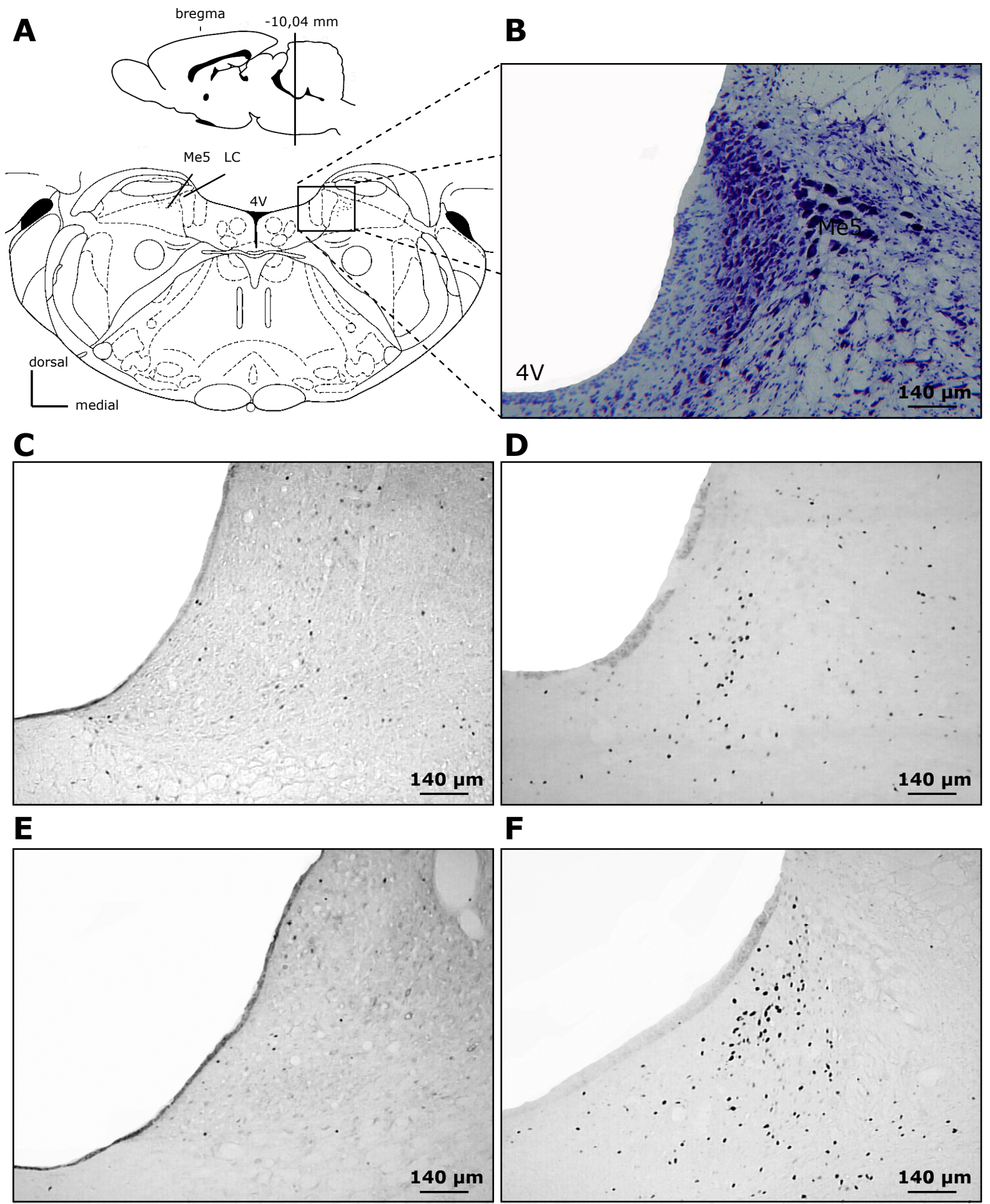

Figura 21. Imunomarcação para Fos no locus coeruleus (LC). Em (A), representação esquemática de uma secção transversal do tronco encefálico do rato, em nível do LC; em (B), fotomicrografia (microscopia de luz) do LC corado pelo método de Nissl; de C - F, fotomicrografias (microscopia de luz) evidenciando o padrão de imunomarcação para Fos, no LC de animais pertencentes aos grupos: CON TOT (C), ART AG (D), ART CR (E) e ART CR AT (F). Abreviações: Me5: núcleo do trato mesencefálico do nervo trigêmeo; $4 \mathrm{~V}$ : quarto ventrículo. 
A

LOCUS COERULEUS (lado ipsilateral)

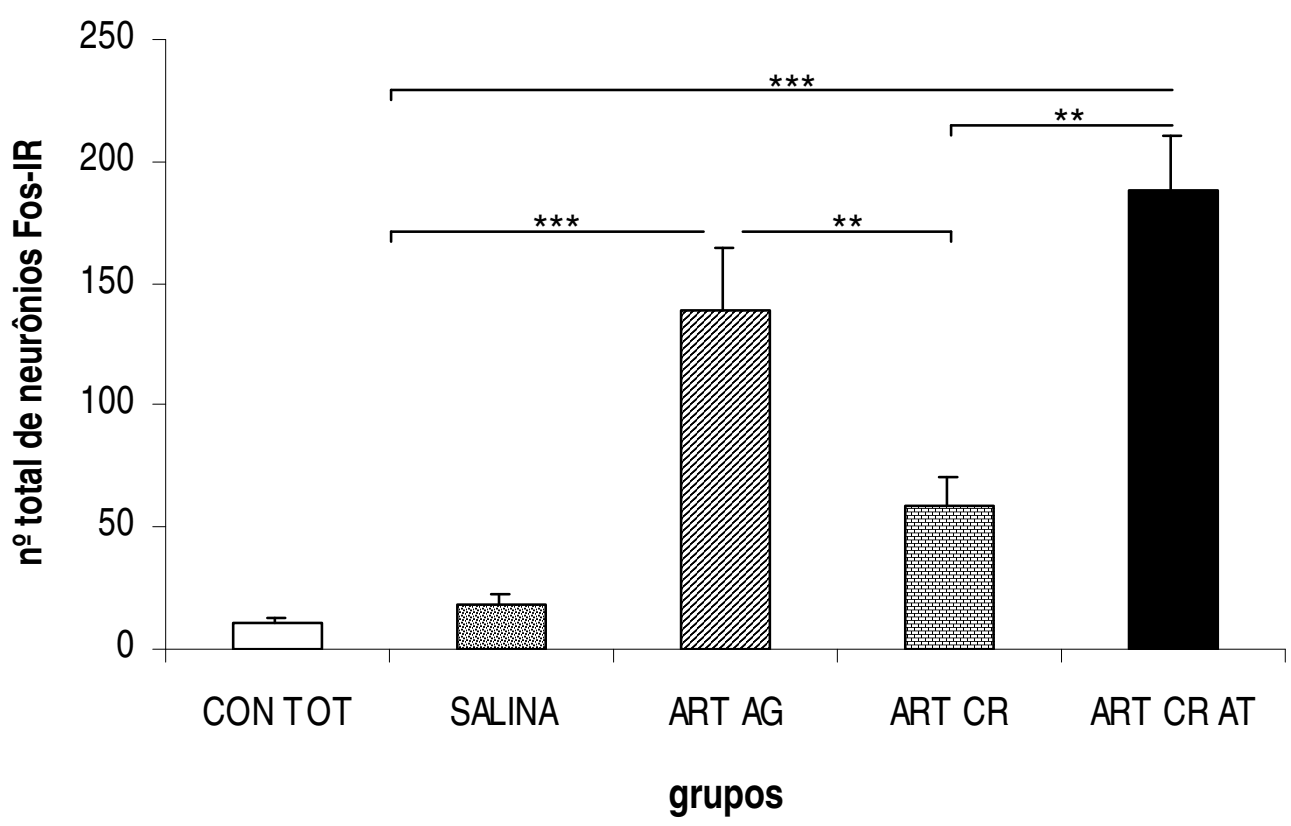

B

LOCUS COERULEUS (lado contralateral)

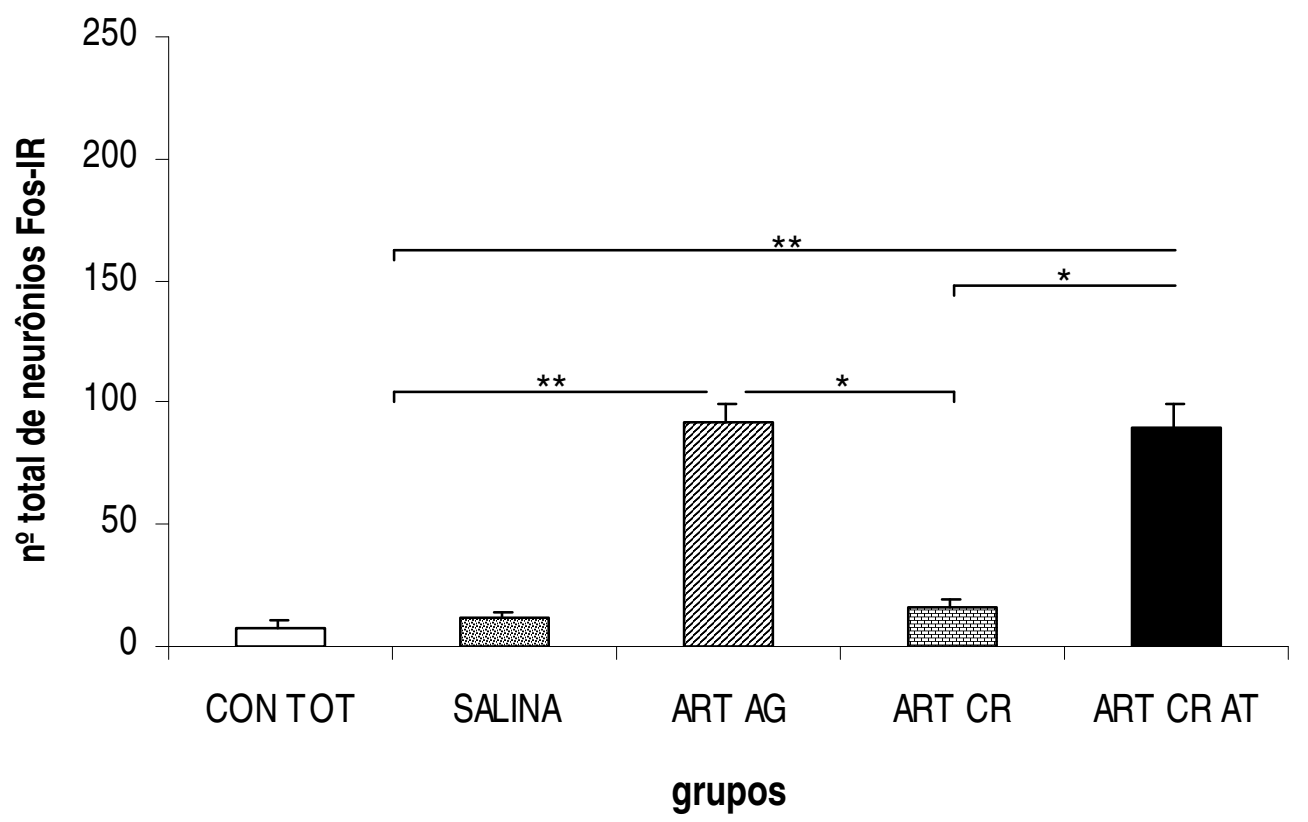

Figura 22. Gráfico evidenciando o efeito da monoartrite no CATM (fases: aguda, crônica e crônica ativa) na expressão de Fos no LC do lado ipsilateral (A) e do lado contralateral (B). Média \pm erro padrão do número total de perfis de neurônios Fos-IR quantificados nas secções analisadas (ordenadas) nos diferentes grupos (abcissas). ${ }^{*} P<0,05$, indica diferença estatisticamente significante; ${ }^{* *} P<0,01$, indica diferença estatisticamente muito significante; ${ }^{* * *} P<0,001$, indica diferença estatística extremamente significante. 


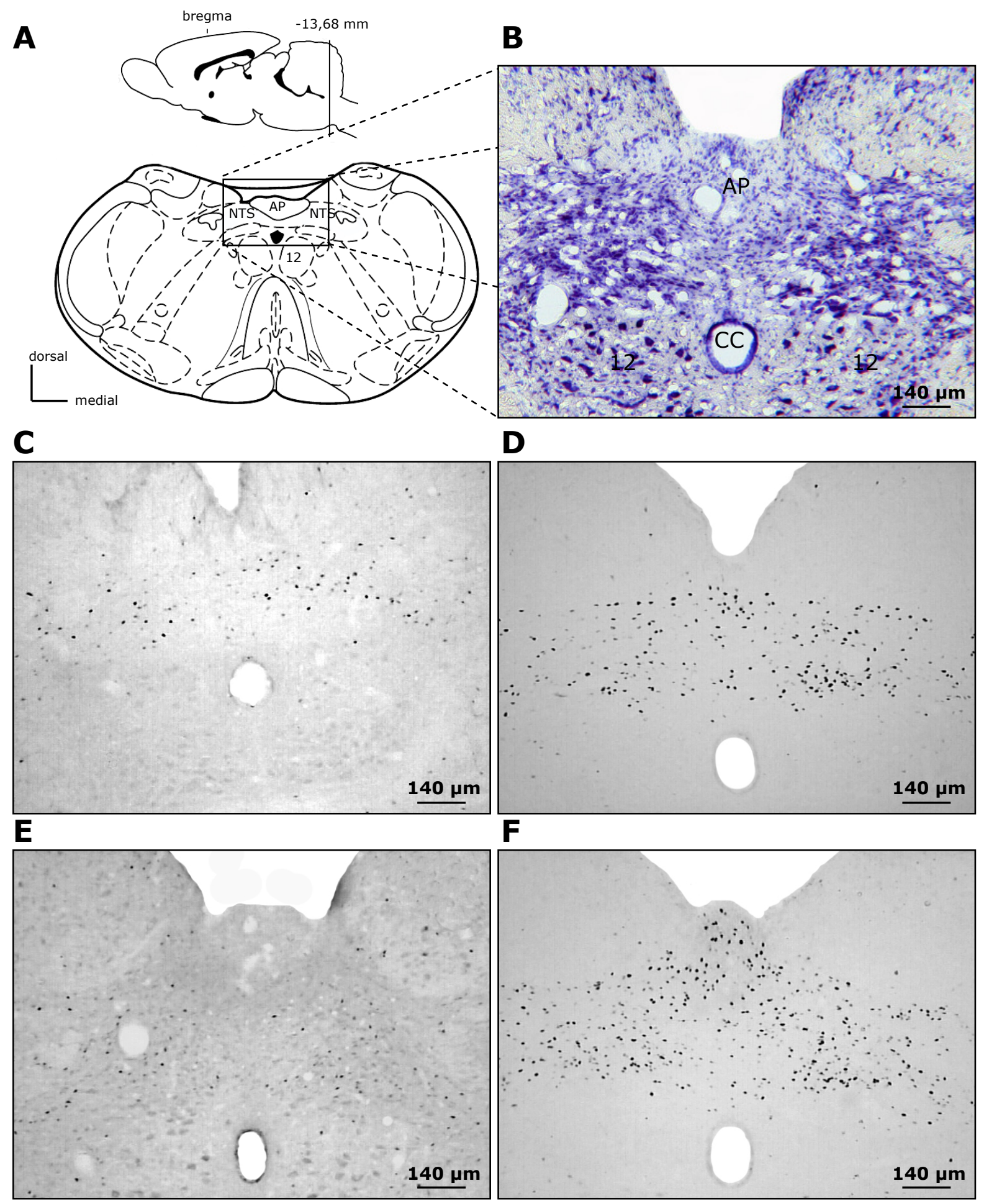

Figura 23. Imunomarcação para Fos no núcleo do trato solitário (NTS). Em (A), representação esquemática de uma secção transversal do tronco encefálico do rato, em nível do NTS; em (B), fotomicrografia (microscopia de luz) do NTS corado pelo método de Nissl; de C - F, fotomicrografias (microscopia de luz) evidenciando o padrão de imunomarcação para Fos, no NTS de animais pertencentes aos grupos: CON TOT (C), ART AG (D), ART CR (E) e ART CR $A T(F)$. Abreviações: AP: área postrema; CC: canal central; 12: núcleo do nervo hipoglosso. 
A

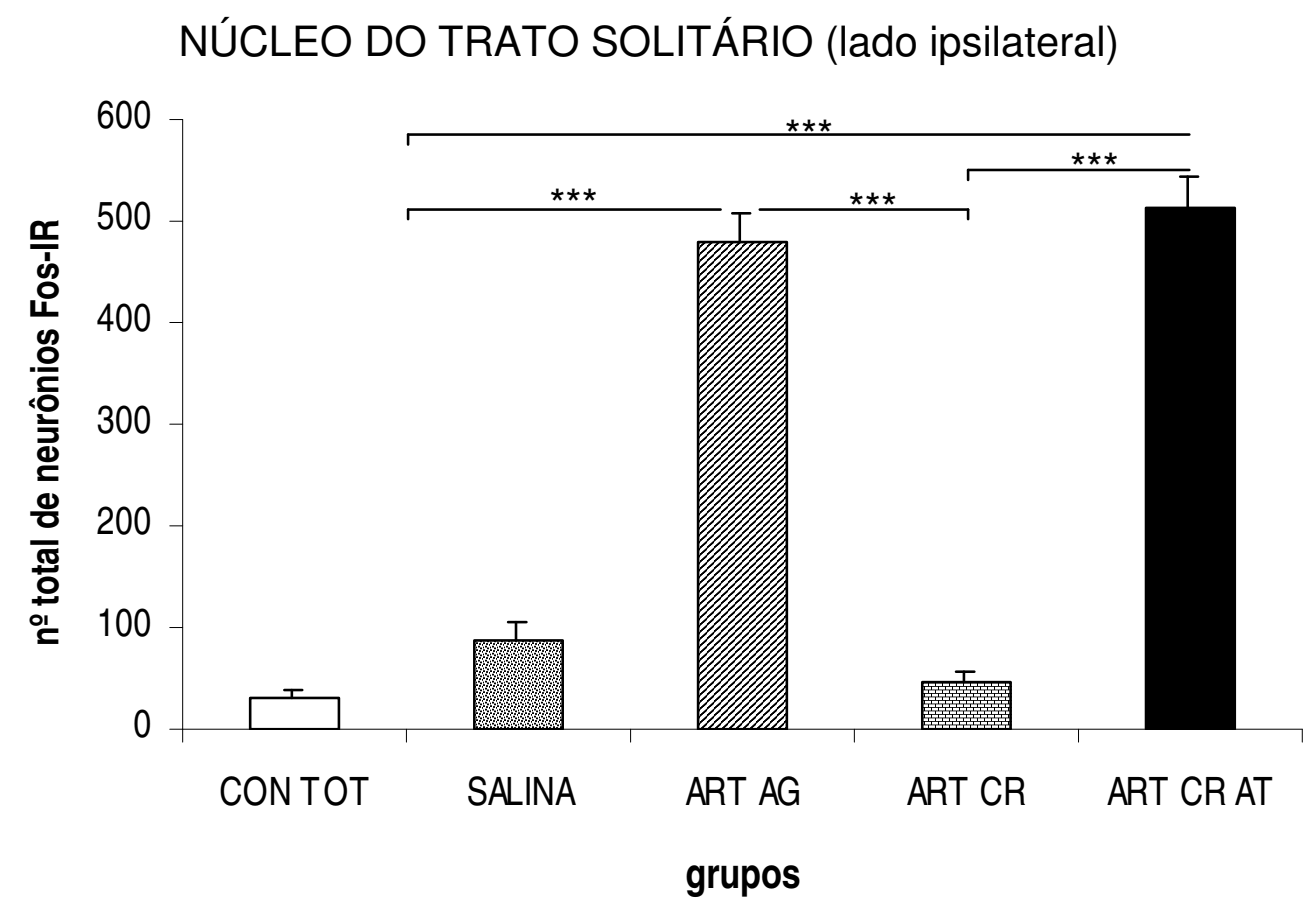

B

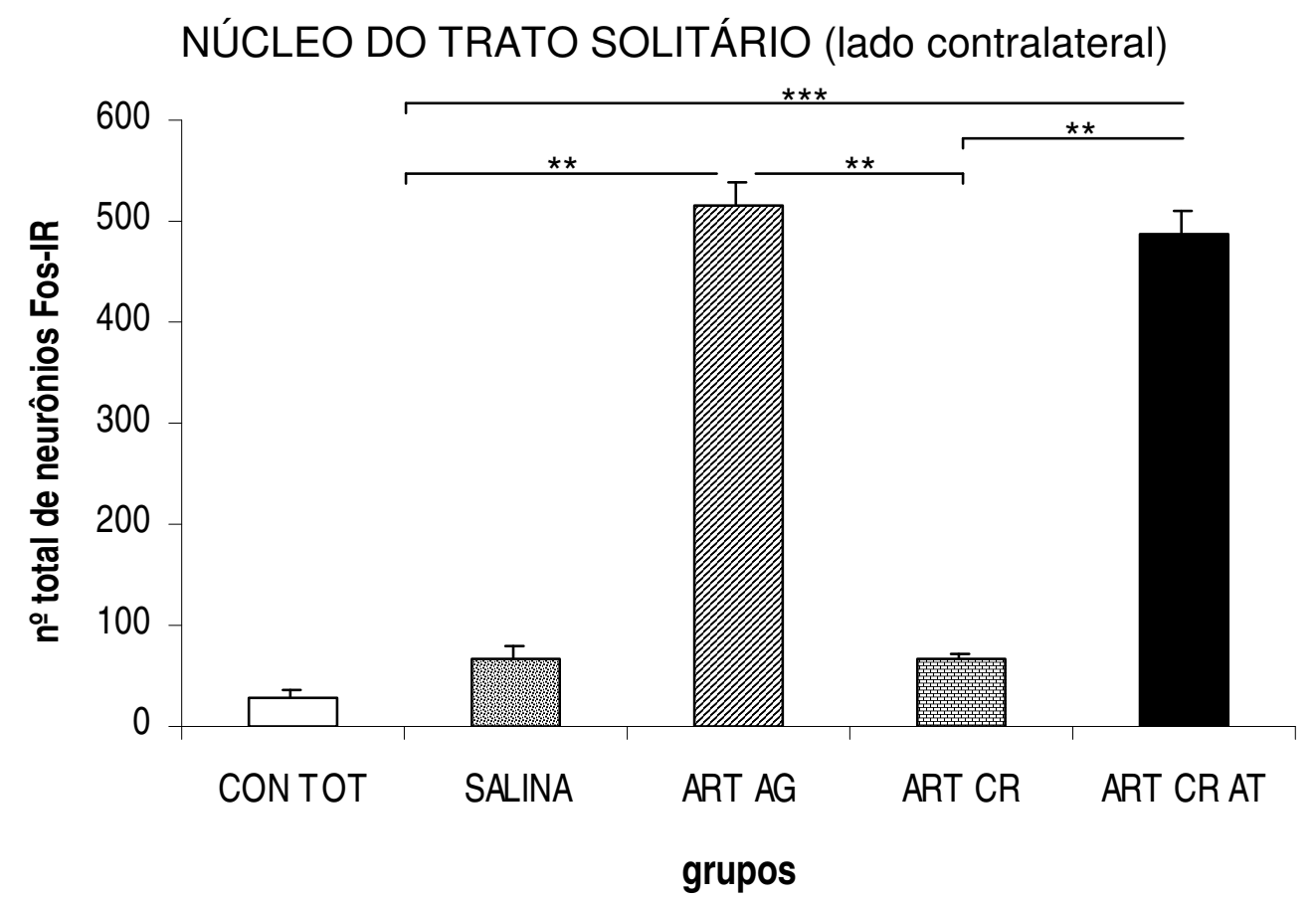

Figura 24. Gráfico evidenciando o efeito da monoartrite no CATM (fases: aguda, crônica e crônica ativa) na expressão de Fos no NTS do lado ipsilateral (A) e do lado contralateral $(B)$. Média \pm erro padrão do número total de perfis de neurônios Fos-IR quantificados nas secções analisadas (ordenadas) nos diferentes grupos (abcissas). ${ }^{*} P<0,05$, indica diferença estatisticamente significante; ${ }^{* *} P<0,01$, indica diferença estatisticamente muito significante; ${ }^{* * *} P<0,001$, indica diferença estatística extremamente significante. 
A

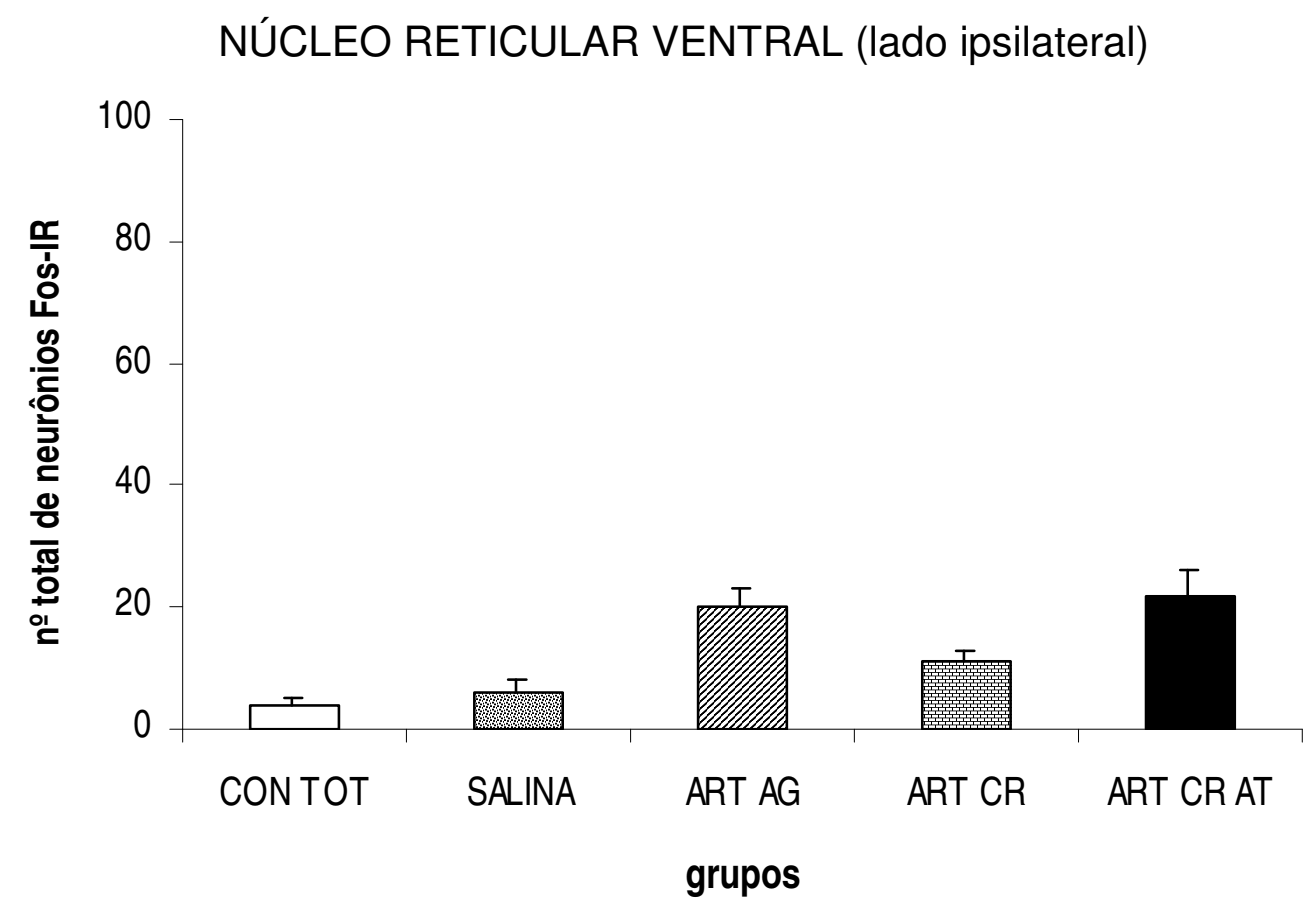

B

NÚCLEO RETICULAR VENTRAL (lado contralateral)

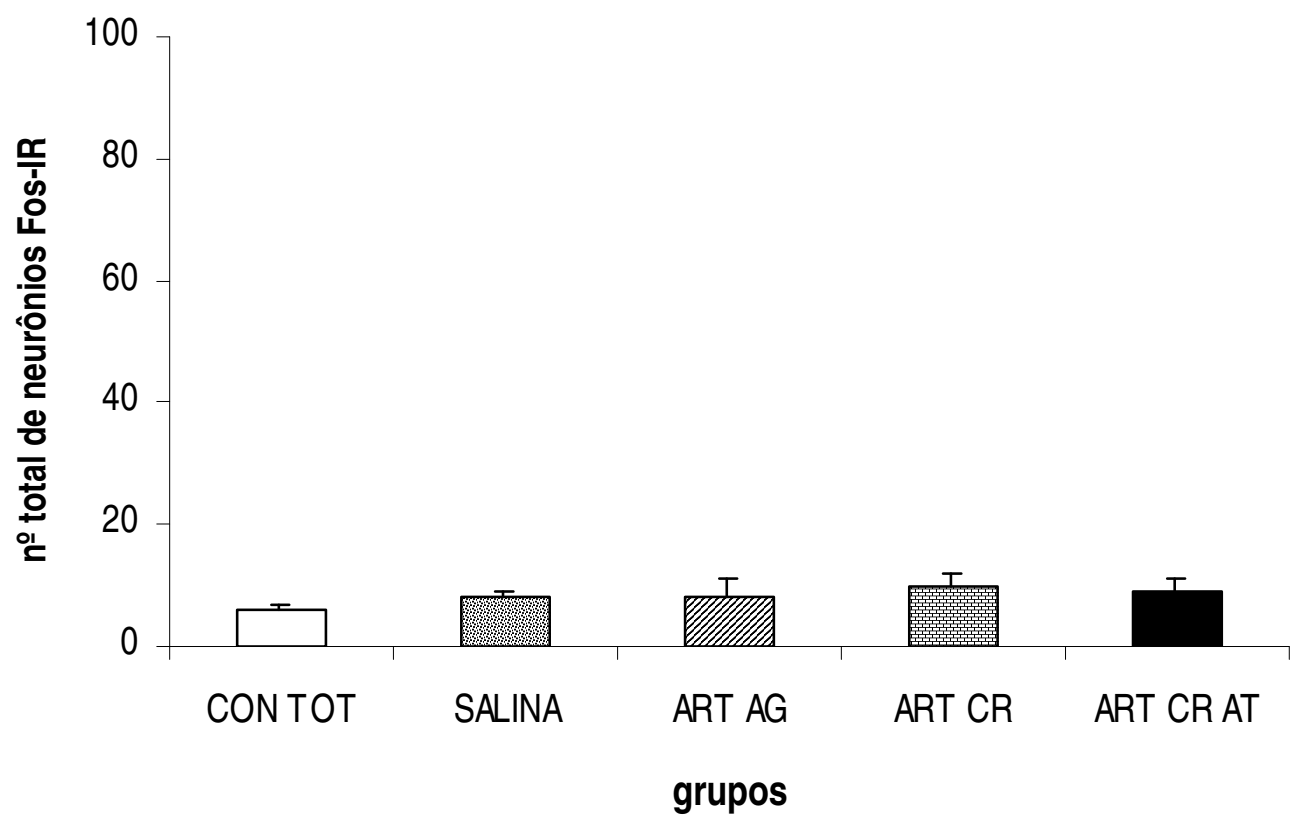

Figura 25. Gráfico evidenciando o efeito da monoartrite no CATM (fases: aguda, crônica e crônica ativa) na expressão de Fos no NRV do lado ipsilateral (A) e do lado contralateral $(B)$. Média \pm erro padrão do número total de perfis de neurônios Fos-IR quantificados nas secções analisadas (ordenadas) nos diferentes grupos (abcissas). ${ }^{*} P<0,05$, indica diferença estatisticamente significante; ${ }^{* *} P<0,01$, indica diferença estatisticamente muito significante; ${ }^{* * *} P<0,001$, indica diferença estatística extremamente significante. 

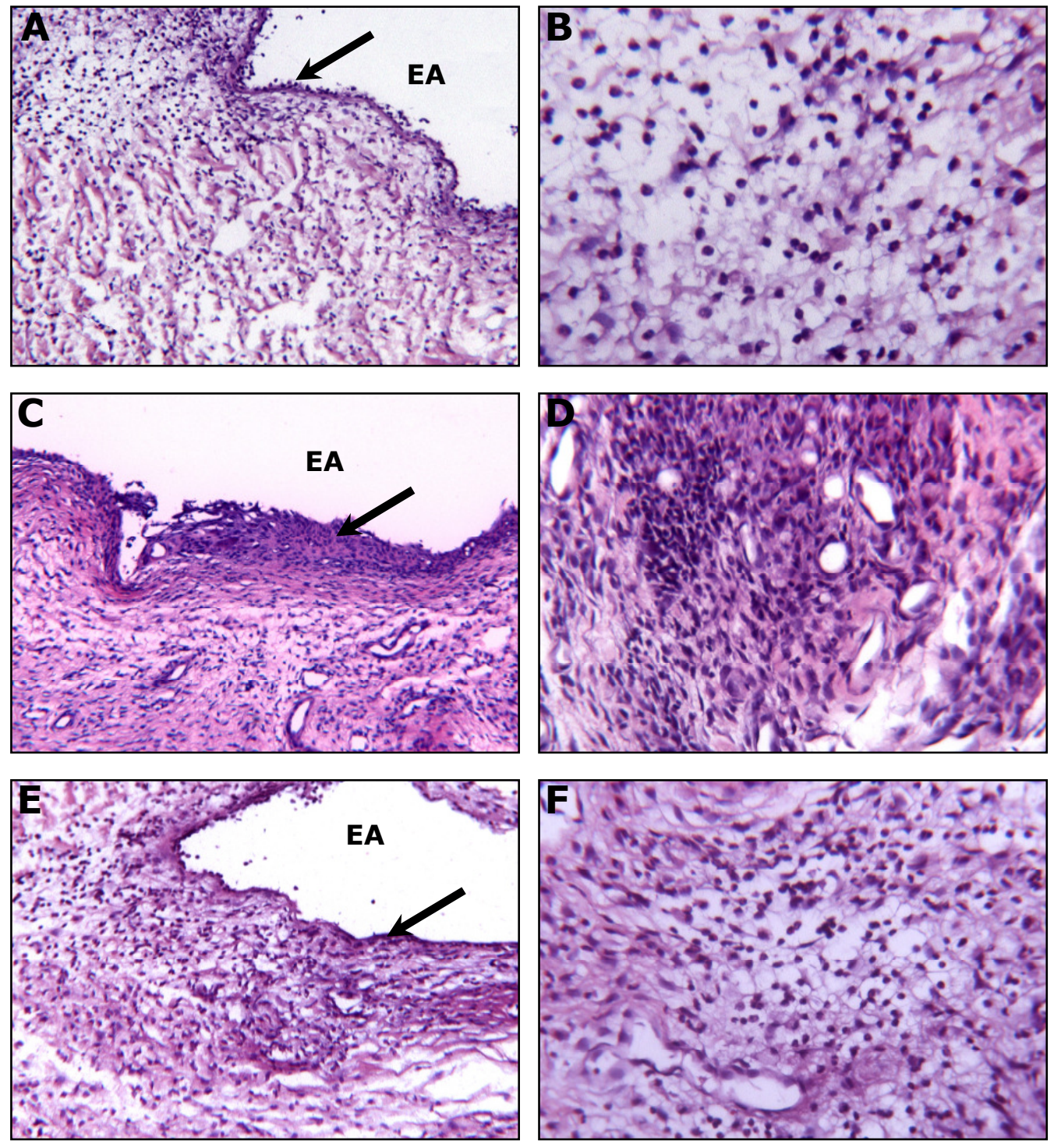

Figura 26. Fotomicrografias (microscopia de luz) de cortes histológicos frontais de ATMs, corados com hematoxilina e eosina, pertencentes aos diferentes grupos experimentais. A coluna da esquerda (aumento de 160X) evidencia o aspecto histológico da membrana sinovial de animais pertencentes aos grupos ART AG (A), ART CR (C) e ART CR AT (E), onde podemos verificar um intenso infiltrado inflamatório na camada subíntima da membrana sinovial e, as principais alterações no padrão de celularidade de sua camada íntima (setas). A coluna da direita (aumento de 400X) mostra o infiltrado inflamatório localizado no tecido conjuntivo subsinovial dos ligamentos intra-articulares, no qual podemos constatar as diferenças entre os tipos de células inflamatórias predominates em cada uma das fases da monoartrite induzida no CATM. Em B, um intenso infiltrado inflamatório constituído basicamente de neutrófilos, ou seja, tipicamente agudo, em um animal do grupo ART AG. Em D, uma grande quantidade de linfócitos caracterizando o infiltrado inflamatório crônico presente em um animal do grupo ART CR. Em F, um infiltrado inflamatório que reúne algumas células mononucleadas, principalmente linfócitos, e uma grande quantidade de polimorfonucleares, predominatemente neutróficos e alguns eosinófilos, caracterizando uma artrite na fase crônica ativa, em um animal do grupo ART CR AT. Os aspectos histológicos de uma ATM em condições de normalidade foram apresentados nas Fig. 2 - 4. Abreviações: EA, espaço articular; CATM, complexo articular temporomandibular. 


\subsection{DISCUSSÃO}

O presente trabalho analisou a influência da monoartrite induzida no CATM do rato quanto ao padrão de ativação neuronal do complexo nuclear trigeminal e, dos centros moduladores da dor, localizados no tronco encefálico. Nas fases aguda e a crônica ativa da monoartrite no CATM constatamos que houve um aumento bilateral no número de perfis de neurônios Fos-IR no Sp5C. A monoartrite crônica no CATM promoveu um aumento na quantidade de perfis de neurônios Fos-IR apenas no Sp5C ipsilateral. Nos centros moduladores da dor localizados no tronco encefálico (PAG, RVM, CVLM, LC e NTS) houve um aumento bilateral significante na quantidade de perfis de neurônios imunomarcados durante as fases aguda e crônica ativa da monoartrite no CATM. No entanto, durante a fase crônica da artrite, a quantidade de perfis de neurônios Fos-IR nestes territórios foi similar aos grupos controle, exceto na PAG onde a quantidade de neurônios marcados se mostrou significativamente maior que nos grupos controle.

\subsubsection{Considerações metodológicas}

A detecção imunoistoquímica do produto protéico do proto-oncogene c-fos, a proteína Fos, consiste em uma das ferramentas neuroanatômicas mais empregadas nas últimas décadas para se monitorar a ativação neuronal decorrente de estímulo nociceptivo (MORGAN e CURRAM, 1991; HARRIS, 1998; HOFFMAN e LYO, 2002; COGGESHALL, 2005). O padrão de expressão de c-fos ou seu produto Fos é depende do tipo de estímulo e de sua duração. Coggeshall (2005) divide o padrão de expressão de Fos em agudo e crônico. O padrão agudo de expressão de Fos deve ser estudado de $2-4$ horas após a aplicação de um estímulo, de alta intensidade, independendo de sua duração. No presente trabalho monitoramos a imunomarcação para Fos 4 horas após a injeção de carragenina na ATM esquerda, consideramos que neste intervalo de tempo o processo inflamatório agudo estava instalado e o produto protéico Fos já havia atingido níveis detectáveis imunoistoquimicamente. Por sua vez, o padrão crônico de expressão de Fos é obtido 
exclusivamente quando o estímulo é contínuo e mantêm uma intensidade relativamente alta durante o seu curso (COGGESHALL, 2005). O modelo inflamatório crônico de injeção intraplantar ou intra-articular de CFA é o mais utilizado na literatura para se verificar a expressão persistente de Fos, a qual pode perdurar por várias semanas (ABBADIE e BESSON, 1992; LANTÉRI-MINET et al., 1993; MA e WOOLF, 1996; LEAH et al., 1996; SCHADRACK et al., 1998; ZHOU et al., 1999). Em nosso trabalho a opção pelo período de 21 dias após a injeção de CFA na ATM esquerda foi para que o processo inflamatório alcançasse sua fase crônica. Como o mecanismo de expressão de Fos após aplicação de um estímulo não é completamente compreendido, não é sabido se a sua expressão a longo prazo é induzida exclusivamente pela inflamação periférica, ou seja também o resultado de alterações ocorridas no sistema nervoso central, em decorrência desta inflamação.

Acreditamos que a confiabilidade dos resultados obtidos por esta técnica dependa de alguns fatores, dos quais destacamos: a manipulação dos animais, o uso adequado de agentes anestésicos e o delineamento experimental. Neste trabalho, antes do delineamento dos grupos experimentais, todos os animais foram submetidos a um período de habituação. Este período consistiu uma fase do experimento na qual os animais foram adaptados ao ambiente, ao operador e a algumas manobras de restrição, cuja finalidade era permitir a anestesia e a injeção intra-articular. Medeiros et al. (2003) reportaram uma significativa redução na quantidade de perfis de neurônios Fos-IR, em diversas áreas encefálicas, quando comparou um grupo de animais submetidos a um protocolo de adaptação com outro que não recebeu este tratamento. Como tal, outros trabalhos relataram que o estresse ocasionado pela manipulação dos animais, provoca alteração na imunomarcação para Fos no sistema nervoso central (MELIA et al., 1994; LAUCHER et al., 1994). Acreditamos que minimizamos sobremaneira a possibilidade de obtermos resultados falso positivos com o protocolo de habituação instituído neste trabalho. Outro ponto que deve ser levado em consideração em experimentos que envolvam a expressão de c-fos é a eleição do agente anestésico. Nossa escolha foi baseada em um estudo realizado por Rocha e Herbert (1997), os quais reportaram que, dentre os anestésicos rotineiramente utilizados, a mistura de cloridrato de cetamina e cloridrato de xilazina foi a que não promoveu alteração significativa na 
expressão de Fos. No entanto, para minimizar ainda mais os possíveis efeitos dos agentes anestésicos, e ainda assim asseguram uma manipulação dos animais isenta de estresse e pautada em princípios éticos, em nosso trabalho, para a realização da injeção intra-articular, utilizavamos uma concentração do agente anestésico dez vezes menor do que a preconizada por pelo trabalho supracitado. Ainda merece destaque, em nosso estudo, o extenso delineamento dos grupos, onde a quantidade de grupos controle aumenta a confiabilidade dos resultados obtidos.

Como pode ser observado, realizamos inúmeros esforços no sentido de aumentarmos ainda mais a confiabilidade de nossos resultados, no entanto, algumas limitações são inerentes à técnica, e impossíveis de serem alteradas, como a baixa imunomarcação para Fos em algumas poucas áreas, sabidamente envolvidas com a nocicepção. Pearse et al. (2001) não obtiveram marcação para Fos no tálamo lateral após aplicação de estímulo nociceptivo na pata posterior de ratos. No presente trabalho constatamos que NRV, um território que desencadeia potente antinocicepção, quando estimulado eletricamente (RANDICH et al., 1990; AICHER e RANDICH, 1990; JONES, 1992), não apresentou alteração na expressão de Fos, quando a ATM estava sob vigência de artrite. Estes dados estão de acordo com aqueles reportados por Pinto et al. (2007), que não constataram alteração na quantidade de neurônios Fos-IR no NRV após artrite induzida no joelho de ratos. Nossos dados reforçam a hipótese postulada por Pinto et al. (2007) que atribuem este padrão de imunomarcação para Fos como uma característica específica dos neurônios do NRV.

Finalmente, no que se refere a indução de artrite na ATM, utilizamos dois modelos clássicos, ou seja, a injeção intra-articular de carragenina ou CFA, preconizadas por Lundeberg et al. (1996) e Zhou et al. (1999), respectivamente. Um diferencial por nós apresentado foi o modelo de monoartrite crônica ativa no CATM, no qual uma primeira injeção intra-articular de CFA promoveu a instalação de uma monoartrite crônica limitada a ATM esquerda e, uma segunda injeção, agora de carragenina, induziu a agudização deste processo inflamatório. Um modelo de monoartrite no CATM na fase crônica ativa trás informações extremamente importantes, uma vez que a artrite reumatóide e algumas outras modalidades de artrite que acometem a ATM, tendem a evoluir para a cronificação, apresentando 
frequentemente episódios de agudização do processo inflamatório ao longo de seu curso (KAMELCHUK e MAJOR, 1995; DONALDSON, 1995; TANAKA et al., 2008). Sendo assim, a análise de um grupo experimental na condição supracitada nos permitiu analisar o padrão de ativação neuronal em áreas que haviam sido previamente sensibilizados.

\subsubsection{Imunomarcação para Fos no complexo nuclear trigeminal sensorial após monoartrite induzida no CATM}

O Sp5C é uma importante estação para o processamento da informação nociceptiva orofacial e, o presente trabalho demonstrou que quando o CATM está sob vigência de monoartrite ocorre um aumento na quantidade de perfis de neurônios Fos-IR neste subnúcleo. Durante a fase aguda da monoartrite induzida no CATM verificamos um aumento bilateral no número de perfis de neurônios Fos-IR ao longo do todo $\mathrm{O} \mathrm{Sp5C}$, com a maior concentração de células imunomarcadas localizada em seu pólo rostral, a transição $\mathrm{Sp} 5 \mathrm{C} / \mathrm{Sp} 5 \mathrm{I}$ e, em seu pólo caudal, a transição $\mathrm{Sp} 5 \mathrm{C} / \mathrm{C} 1,2$. Nossos resultados corroboram com aqueles obtidos em trabalhos prévios, os quais reportaram um aumento bilateral no número de perfis de neurônios Fos-IR no Sp5C, após a indução de inflamação aguda na ATM (HATHAWAY et al., 1995). De acordo com resultados obtidos em estudo prévio (ZHOU et al., 1999) constatamos ainda que, quando o CATM estava sob vigência de monoartrite crônica, o aumento na quantidade de perfis de neurônios Fos-IR ficou restrito as zonas de transição Sp5C/Sp5I e Sp5C/C1-C2, no lado ipsilateral, no entanto, a quantidade de neurônios imunomarcados se mostrou significativamente menor que aquela apresentada pelos animais com monoartrite aguda no CATM. Zhou et al. (1999) analisaram a expressão de Fos no Sp5C 2h, 24h, 3d e 10d após injeção de CFA em uma das ATMs do rato e constataram que a quantidade de perfis de neurônios Fos-IR foi proporcional a magnitude do processo inflamatório articular, sendo que a imunomarcação máxima para Fos ocorreu 3 dias após a injeção de CFA na ATM, ou seja, no pico da resposta inflamatória aguda, sofrendo um decréscimo ao longo do período analisado, no entanto se mantendo aumentada em relação ao controle. Tais achados corroboram com nossos resultados, onde a 
expressão de Fos foi analisada 21 dias após injeção de CFA na ATM esquerda, em uma fase mais tardia do processo inflamatório crônico, o que explica a redução no número de células imunomarcadas e a significância estatística ficando confinada a determinados segmentos do Sp5C.

Em nosso estudo constatamos que a expressão de Fos, no Sp5C, foi significativamente maior que nos demais grupos experimentais, quando o CATM estava sob vigência de monoartrite na fase crônica ativa. O padrão rostrocaudal de distribuição de perfis de neurônios Fos-IR neste grupo experimental foi similar aquele observado no grupo com monoartrite aguda no CATM. Acreditamos que nesta situação o aumento na expressão de Fos seja resultado de alterações periféricas, alterações centrais ou ambas. As alterações periféricas desencadeadas durante a evolução da inflamação articular, supostamente contribuem para o aumento na excitabilidade de neurônios aferentes primários, o que consequentemente pode facilitar a expressão de Fos, durante a recorrência de um episódio de agudizacão do processo inflamatório. O aumento na excitabilidade de neurônios aferentes primários têm sido reportado após indução de artrite na ATM (FLAKE e GOLD, 2005; FLAKE et al., 2005). Dentre as alterações neuroplásticas observadas no sistema nervoso central em decorrência da inflamação persistente, aquelas relacionadas com a sinalização intracelular têm sido amplamente estudadas nos últimos anos. Alguns estudos reportam mudanças na atividade de moléculas sinalizadoras intracelulares, incluindo as proteína-quinases ativadas por mitógeno, proteína-quinase regulada por sinal extracelular (ERK, "extracelullar signal-regulated kinase") e p38, e o fator de transcrição CREB ("cAMP element-binding protein") após indução de inflamação periférica. No Sp5C foi reportado um aumento significante no número de neurônios imunorreativos ao ERK fosforilado, após injeção de formalina na pele da face (HUANG et al., 2000). A proteína-quinase ativada por mitógeno, p38, é ativada no corno dorsal da medula espinal após inflamação induzida na pata posterior de ratos (SVENSSON et al., 2003) ou após a ligadura de nervo espinal (JIN et al., 2003). Um significativo aumento de CREB fosforilado foi descrito no corno dorsal da medula espinal, após estimulação elétrica ou química da pata posterior de ratos (JI e RUPP, 1997; KAWASAKI et al., 2004). Alterações similares podem ter ocorrido ao nível do Sp5C quando o CATM estava sob vigência de monoartrite 
crônica ativa, sendo assim, tais alterações poderiam ser as principais responsáveis pelo maior número de perfis de neurônios Fos-IR observado neste grupo experimental.

Como pôde ser constatado no exposto acima, o aumento mais expressivo na quantidade de perfis de neurôniois Fos-IR, nos grupos experimentais acometidos por monoartrite no CATM, ocorreu nas zonas de transição do Sp5C com o Sp5I e com $\mathrm{C} 1$,2. Este padrão de imunomarcação para Fos no $\mathrm{Sp} 5 \mathrm{C}$ condiz com estudos prévios (HATHAWAY et al., 1995; ZHOU et al., 1999; IMBE et al., 1999; SATO et al., 2005). A explicação para se obter este padrão de imunomarcação para Fos pode vir da correlação dos resultados obtidos no presente trabalho, com dados resultantes de trabalhos prévios envolvendo traçamento de vias neurais. Alguns trabalhos, que se utilizaram de traçamento neuronal retrógrado, sugerem que neurônios aferentes primários que inervam a ATM do rato se projetam principalmente para o pólo mais caudal do Sp5C, o que explicaria a grande quantidade de neurônios Fos-IR neste segmento do Sp5C verificado no corrente estudo, em contrapartida, não há relatos de projeção direta de neurônios aferentes primários que inervam a ATM para a zona de transição Sp5C/Sp5I (JACQUIN et al., 1983; PFALLER e ARVIDSSON, 1988; MARFURT e RAJCHERT, 1991). Sato et al. (2005) realizaram um estudo de traçamento neuronal retrógrado aliado a técnica imunoistoquímica para detecção de Fos no Sp5C, 3 dias após a injeção de CFA em uma das ATMs de ratos. Estes autores verificaram que quando o traçador neuronal "fluorogold" é injetado na zona de transição Sp5C/Sp5I uma grande quantidade de neurônios duplamente marcados (Fos-IR e Fluorogold positivos) foi observada no pólo caudal do Sp5C. Sendo assim, estes autores concluíram que a zona de transição $\mathrm{Sp} 5 \mathrm{C} / \mathrm{C} 1,2$ modula a atividade da zona $\mathrm{Sp} 5 \mathrm{C} / \mathrm{Sp} 5 \mathrm{I}$, através de uma via neural intrínseca ascendente. A existência desta via neural, indica que a ativação dos neurônios da zona $\mathrm{Sp} 5 \mathrm{C} / \mathrm{Sp} 5 \mathrm{l}$ é mediada pela zona $\mathrm{Sp} 5 \mathrm{C} / \mathrm{C} 1,2$, o que corrobora com a grande quantidade de perfis de neurônios Fos-IR no pólo rostral do Sp5C, observada em nosso estudo. No que refere ao aspecto funcional, sugere-se que estes dois segmentos do Sp5C exerçam funções distintas no processamento da informação nociceptiva. Vários experimentos, utilizando diversas drogas analgésicas, relatam respostas diferentes entre os grupamentos de neurônios localizados na zona de transição Sp5C/Sp5I e Sp5C/C1,2 
(MENG et al., 1998; BEREITER e BEREITER, 2000; OKAMOTO et al., 2006). Em um estudo recente, Okamoto et al. (2007) reportaram que após a injeção de formalina na ATM do rato houve um aumento significativo na expressão de Fos na região Sp5C/Sp5I e Sp5C/C1,2, no entanto, a administração de agonista do receptor de serotonina $2 \mathrm{~A}(5 \mathrm{HT} 2 \mathrm{~A})$ inibiu a expressão de Fos apenas na zona $\mathrm{Sp} 5 \mathrm{C} / \mathrm{C} 1,2$, local onde Fay e Kubin (2000) demonstraram a presença destes receptores. Como pode ser constatado o pólo rostral e o caudal do Sp5C, apresentam diversas diferenças no que se refere a suas principais aferências, eferências e características neuroquímicas, o que substancia a suposição de que estes dois territórios possuem papéis distintos durante o processamento da informação nociceptiva no sistema trigeminal.

No que se refere a distribuição laminar de neurônios Fos-IR constatamos que, independente da fase da monoartrite induzida no CATM, havia um predomínio de perfis de neurônios Fos-IR nas lâminas superficiais do $\mathrm{Sp} 5 \mathrm{C}$, coincidente com a grande quantidade de neurônios nociceptivos específicos relatado por alguns estudos (DAWSON et al., 1980; HU e SESSLE, 1984). Além disso, observamos um considerável número de neurônios Fos-IR nas lâminas profundas do $\mathrm{Sp} 5 \mathrm{C}$, quando o CATM estava sob vigência de monoartrite na fase crônica e crônica ativa, o que corrobora com estudos que analisaram a expressão de Fos no Sp5C e no corno dorsal da medula espinal durante a vigência de inflamação periférica (HONORE et al., 1995; ZHOU et al., 1999; BEREITER e BEREITER, 2000).

Durante a fase aguda e a crônica ativa da monoartrite na ATM constatamos um aumento bilateral na expressão de Fos no Sp5C, estes dados estão de acordo com os reportados em estudos anteriores (HATHAWAY et al. 1995; BEREITER e BEREITER, 2000; BEREITER et al., 2002). Todavia, as bases neurais que procuram explicar as respostas simétricas desencadeadas pela monoartrite não são totalmente estabelecidas. Há algumas suposições, baseadas em poucas evidências, para explicar estes resultados. Primeiro, fibras nervosas aferentes pertencentes a neurônios do gânglio trigeminal se projetam através da linha mediana para o complexo nuclear trigeminal contralateral, no entanto, contrariando tal suposição, inúmeros estudos que se utilizaram de traçamento neuronal retrógrado falham na evidenciação desta via (LEVINE et al., 1985; DONALDSON, 1999; SHENKER et al., 
2001). Todavia, Marfut e Rajchert (1991) realizaram o único trabalho que aponta evidências concretas de projeções de fibras nervosas de neurônios do gânglio trigeminal do lado ipsilateral para o contralateral. Segundo, através de uma via polissináptica supra-espinal descendente, ocorre a ativação do complexo nuclear trigeminal contralateral (LEVINE et al., 1985; DONALDSON, 1999; SHENKER et al., 2001). Terceiro, não podemos descartar a participação das células da glia, através da produção de citocinas, na intermediação das respostas neurais bilaterais (MILLIGAN et al. 2001). Do ponto de vista funcional, a ativação bilateral da via trigeminal nociceptiva parece ser de extrema importância, uma vez que supostamente auxiliam na coordenação dos reflexos protetivos e na integração das respostas a estímulo nocivo.

\subsubsection{Imunomarcação para Fos no sistema endógeno de modulação da dor após monoartrite induzida no CATM}

A informação nociceptiva que atinge o Sp5C está sob influência de grupamentos neuronais que constituem o sistema endógeno de modulação da dor (BASBAUM e FIELDS, 1984; CARTENS, 1987; FIELDS e BASBAUM, 1989; GEBHART e RANDICH, 1990; JONES, 1992). No presente estudo constatamos alterações no padrão de expressão de Fos, após monoartritre induzida no CATM, na maioria dos centros que constituem o sistema endógeno de modulação da dor.

A PAG apresentou um aumento significativo na expressão de Fos em todas as fases da monoartrite induzida experimentalmente no CATM, sendo que a maior densidade de células imunomarcadas foi observada em sua porção ventrolateral, o que está de acordo com estudos prévios, os quais reportaram que a dor somática profunda e a dor visceral desencadeiam uma intensa ativação da PAG ventrolateral, ao passo que a dor somática superficial promove maior ativação da PAG lateral (KEAY e BANDLER, 1993; RODELLA et al., 1998; OHTORI et al., 2000). Supostamente, uma parcela considerável de perfis de neurônios Fos-IR localizados na PAG ventrolateral, durante a vigência de artrite na ATM, sejam ativados diretamente por neurônios de segunda ordem localizados no Sp5C. Tal suposição está fundamentada no fato de que tanto o traçamento neuronal retrógrado, quanto o 
anterógrado, revelaram que dentre as principais aferências e eferências da porção ventrolateral da PAG, estão as lâminas superficiais do Sp5C, de ambos os lados (BLOMQVIST e CRAING, 1991; MORGAN et al., 1997). Estudos clássicos reportaram uma intensa analgesia comportamental em animais submetidos a estimulação elétrica da PAG (REYNOLDS, 1969; MAYER et al., 1971; MAYER e LIEBESKIND, 1974; MAREK et al., 1991), o que nos permite inferir que grande parte dos perfis de neurônios Fos-IR observados no corrente estudo estejam envolvidos na modulação da resposta nociceptiva ao nível do Sp5C, trata-se de uma via inibitória descendente que atua em neurônios aferentes primários, tanto ao nível do corno dorsal da medula espinal, quanto do Sp5C (MORGAN et al., 1997; LI et al., 1993). Estudos que se utilizaram da microinjeção de aminoácidos excitatórios, como o glutamato, na PAG, confirmam o seu papel inibitório, uma vez que descrevem supressão da resposta dos neurônios do corno dorsal da medula espinal a um estímulo nocivo (JONES e GEBHARD, 1988; SANDKUHLER et al., 1988; SANDKUHLER et al., 1991). Estudos hodológicos evidenciam que além de poder modular a resposta nociceptiva diretamente ao nível do Sp5C, a PAG também a faz de modo indireto, via RVM, uma de suas principais eferências no tronco encefálico (BEITZ et al.,1983), e como mostram alguns trabalhos mais recente, via CVLM (COBOS et al., 2003), LC (LEE et al., 2005) e NTS (GAO e MASON, 2000). No presente trabalho verificamos que esse aumento na quantidade de perfis de neurônios Fos-IR na PAG foi bilateral, tais dados também encontram suporte em estudos hodológicos onde, após a injeção do traçador neuronal anterógrado, leucoaglutinina do Phaseolus vulgaris na PAG, se verificou marcação de ambos os lados do Sp5C, embora ocorresse uma preleção pelo lado ipsilateral (LI et al., 1993). LEVINE et al., (1991) reportaram que a estimulação elétrica da PAG de ratos, durante o teste da placa quente, promove analgesia comportamental de ambos os lados, no entanto esta é maior no lado ipsilateral.

A RVM mostrou um aumento significativo no número de perfis de neurônios Fos-IR durante as fases aguda e crônica ativa da monoartrite no CATM, com uma densidade maior de neurônios imunomarcados no núcleo magno da rafe. Nossos resultados estão de acordo com os reportados por trabalhos prévios, os quais verificaram um aumento significativo na expressão de Fos após inflamação periférica 
induzida experimentamente (SENBA et al., 1993; LANG e LI, 1998; ZHOU et al., 1999; OH et al., 2006; PINTO et al., 2006; PINTO et al., 2007). A utilização de outras ferramentas neuroanatômicas também corroboram com os resultados do corrente estudo. Neto et al., 1999, em um estudo da atividade neuronal no sistema nervoso central, baseada na utilização de glicose, demonstrou um substancial aumento na atividade metabólica dos neurônios do núcleo magno da rafe e do núcleo reticular gigantocelular, quando um dos joelhos do rato estava sob vigência de artrite aguda, induzida por CFA. Em estudos mais recentes, os quais se utilizaram do nível de fosforilação da proteína-quinase regulada por sinal extracelular (ERK, "extracelullar signal-regulated kinase"), para mensurar ativação neuronal, constataram um aumento significante de pERK na RVM durante a vigência de inflamação aguda na pata posterior de ratos submetidos a injeção local de CFA (IMBE et al., 2005; IMBE et al., 2007). Do ponto de vista funcional, a literatura científica atual apresenta inúmeras controversas a respeito da efetiva função da RVM na modulação da resposta nociceptiva. Alguns trabalhos reportam seu papel como importante centro de inibição descendente da nocicepção, ao passo que outros, a colocam como um centro de facilitação descendente desta modalidade sensorial. Após a aplicação de um estímulo nocivo, a estimulação química ou elétrica da RVM, provoca inibição da resposta de neurônios nociceptivos do corno dorsal da medula espinal e diminui a hiperalgesia comportamental (JENSEN e YAKSH, 1984; FIELDS et al., 1991; MCGOWAN e HAMMOND, 1993). Em consonância com estes últimos, a lesão da RVM acarreta em acentuada hiperalgesia comportamental em ratos submetidos a aplicação de estímulo nociceptivo (HEINRICHER e KAPLAN, 1991). Em contrapartida, a microinjeção de baclofen na RVM resulta em antinocicepção ou hiperalgesia, dependendo a dose utilizada (THOMAS et al., 1995). Urban et al., (1996) ainda descreveram atenuação da hiperalgesia induzida pela injeção de óleo de mostarda, na pata posterior de ratos previamente submetidos a lesão eletrolíca na RVM. Tendo em vista tais controversas, Wei et al. (1998) realizaram um extensivo estudo onde a hiperalgesia comportamental e, a expressão de Fos ao nível da medula espinal foram mensurados em ratos com inflamação aguda da pata posterior, e que haviam sido previamente submetidos a lesão eletrolítica ou química de diferentes porções da RVM. Este trabalho concluiu que as diferentes porções que 
compõem a RVM apresentam um papel diferencial na modulação da resposta nociceptiva. Segundo Wei et al. (1998), o núcleo magno da rafe é a principal fonte de modulação inibitória descendente da nocicepcão, ao passo que o núcleo reticular gigantocelular é a fonte de modulação facilitatória descendente. Miki et al. (2002) relataram que o papel da RVM na modulação da nocicepção é o resultado do balanço entre suas influências inibitórias e facilitatórias sob os neurônios do corno dorsal da medula espinal ou do $\mathrm{Sp} 5 \mathrm{C}$, no entanto este balanço é profundamente influenciado pelo tipo de estímulo (inflamação, irritação tecidual química ou lesão neuropática) (VANEGAS e SCHAIBLE, 2004). Diante do exposto, em nosso trabalho acreditamos que o aumento no número de perfis de neurônios Fos-IR na RVM, durante a fase aguda e a crônica ativa da monoartrite induzida no CATM, possa significar um aumento da atividade inibitória e facilitatória descendente sob os neurônios do $\mathrm{Sp} 5 \mathrm{C}$, no entanto, como há um predomínio de neurônios imunomarcados no núcleo magno da rafe, em ambas as condições experimentais supracitadas, podemos especular que prevalença o mecanismo de inibição descendente sob o Sp5C. O núcleo magno da rafe concentra uma enorme população de neurônios serotoninérgicos que se projetam para o Sp5C e, consequentemente, atuariam na modulação da nocicepção orofacial (LI et al., 1997; STORER e GOADSBY, 1997; SEO et al., 2002; OKAMOTO et al., 2005). Entre os vários subtipos de receptores de serotonina detectados no $\mathrm{Sp5C}$, estudos apontam o 5HT2A como aquele envolvido com a modulação da nocicepção craniofacial profunda (OKAMATO et al., 2005; OKAMATO et al., 2006; OKAMATO et al., 2007). Okamato et al. (2007) relataram que a ativação dos receptores 5HT2A, através da utilização de seu agonista, dimetoxiiodoanfetamina, especificamente na zona de transição Sp5C/C1,C2, desencadeia uma potente modulação inibitória na nocicepção craniofacial. No entanto, deve ser levado em consideração que outros sistemas de neuromediadores presentes no núcleo magno da rafe, os quais se projetam para o Sp5C, estão envolvidos com a modulação da nocicepção, como o ácido gama amino butírico e a encefalina (BEITZ, 1982; BEITZ et al., 1983). Por fim, verificamos em nosso trabalho que durante a fase crônica da monoartrite no CATM, a quantidade de perfis de neurônios Fos-IR na RVM não sofreu alteração, sendo 
assim supomos que sua atuação, tanto modulando a facilitação quanto a inibição da nocicepção, seja significativamente diminuída nesta fase da artrite na ATM.

$\mathrm{Na}$ CVLM o número de perfis de neurônios Fos-IR também aumentou bilateralmente após monoartrite induzida no CATM, nas fases aguda e crônica ativa. Estando de acordo com nossos resultados, diferentes modalidades de estímulos nocivos, como por exemplo, artrite induzida no joelho, irritação química de músculo, inflamação da vesícula urinária, peritonite induzida experimentalmente, todos promovem um aumento bilateral significativo na expressão de Fos na CVLM (RODELLA et al., 1998; IMBE et al., 1999; TAVARES e LIMA, 2002). O padrão de conectividade entre ambos os lados do CVLM e, entre esta e o Sp5C, local onde constatamos uma intensa imunomarcação para Fos durante as diferentes fases da artrite, poderia, parcialmente, nos auxiliar a compreender a substancial imunomarcação nesta região bulbar. Estudos envolvendo traçamento neuronal demonstraram a existência de conexões diretas entre o CVLM ipsilateral e o contralateral e, entre esta primeira e ambos os lados do Sp5C, no entanto com um maior contingente de fibras se projetando para o lado ipsilateral (COBOS et al., 2003). Tavares et al. (1998) descreveram conecções recíprocas entre o CVLM e as lâminas superficiais do corno dorsal da medula espinal. Além disso, um estudo hodológico reporta o núcleo magno da rafe e o grupamento A5 de células noradrenégicas como as principais eferências da CVLM no tronco encefálico (TAVARES et al., 1996). Diante do exposto, podemos concluir que a CVLM atua diretamente ao nível espinal e, supostamente ao nível trigeminal ou, se utiliza de duas vias clássicas de modulação inibitória descendente, uma via serotoninérgica originada no núcleo magno da rafe e, uma via noradrenérgica originada no grupamento A5. Estudos farmacológicos que se utilizaram da administração simultânea de antagonistas de $\alpha_{2^{-}}$adrenoceptores e de receptores de serotonina não aboliram completamente a antinocicepção provocada pelo estimulação elétrica da CLVM, frente a aplicação de um estímulo nocivo (GEBHART e OSSIPOV, 1986; JANSS e GEBHART, 1987). Diante disso, a via direta citada anteriormente, pode produzir modulação inibitória da nocicepção através de outros neuromediadores, os quais ainda precisam ser estabelecidos, e ainda não podemos descartar de existência de vias multissinápticas que partem da CVLM e que tem como alvo o 
corno dorsal da medula espinal ou o Sp5C. Um outro fato, que suporta a importância da via direta ou a existência de vias multissinátpica partindo da CVLM é que a antinocicepção produzida pela estimulação elétrica desta área difere sobremaneira daquela desencadeada pela estimulação de outras áreas envolvidas com a antinocicepção. Vários trabalhos constataram que analgesia produzida pela estimulação elétrica ou química da CVLM é de intensidade e duração muito maiores que a desencadeada por outras componentes do sistema endógeno de modulação da dor (SATOH et al., 1983; JENSEN e YAKSH, 1984; CARSTENS e WATKINS, 1986; JONES e GEBHART, 1986; NESS e GEBHART, 1987). Alguns trabalhos sugerem que a CVLM seja responsável pela inibição tônica descendente de neurônios nociceptivos (HALL et al., 1982; FOONG e DUGGAN, 1986). Deve ser levado em consideração que a CVLM controla ativamente outras funções, das quais a regulação cardiovascular, o que a coloca como um relé potencialmente importante para explicar os reflexos que a nocicepção provoca no sistema cardiovascular (WILLETE et al., 1983; TAVARES et al., 1997). Sendo assim, podemos especular que a grande quantidade de perfis de neurônios Fos-IR observados no CVLM de ambos os lados, quando a ATM esquerda estava sob vigência de artrite aguda ou crônica ativa, sejam neurônios envolvidos com a modulação inibitória da resposta nociceptiva ao nível do Sp5C. No entanto, constatamos ainda que durante a fase crônica da monoartrite no CATM o padrão de ativação de Fos do CVLM é semelhante aquele observado nos grupos controle, o que sugere um participação menos efetiva deste centro modulador da dor durante a evolução da artrite na ATM.

Houve um aumento significante na quantidade de perfis de neurônios Fos-IR no LC quando a ATM esquerda estava sob vigência de artrite na fase aguda e na fase crônica ativa. Estes dados estão de acordo com aqueles obtidos por Oh et al. (2006), os quais verificaram um aumento na expressão de Fos-IR no LC ipsilateral, após a injeção de formalina no músculo masseter de ratos, cuja ATM se mostrava em condições de normalidade ou sob vigência de artrite na fase crônica. Um achado interessante do presente trabalho, que não foi avaliado no estudo de Oh et al. (2006), foi que a monoartrite no CATM, na fase aguda e crônica ativa, promoveu um aumento bilateral na expressão de Fos no LC. A semelhança de nossos resultados, a inflamação unilateral induzida pela injeção de carragenina em uma das patas 
posteriores do rato, desencadeou um aumento bilateral significativo na quantidade Fos-IR no LC de ambos os lados (TSURUOKA et al., 2003). Estudos neuroanatômicos que se utilizaram de traçamento neuronal evidenciam que o LC envia projeções descendentes para ambos os lados da medula espinal e do Sp5C (CLARK e PROUDFIT, 1991; CLARK et al., 1991; SLUKA e WESTLUND, 1992; LI et al., 1993). Trabalhos que aliaram estudo comportamentais e lesão eletrolítica do LC evidenciam a importância das projeções bilaterais originadas neste núcleo. Em ratos, a lesão eletrolítica bilateral do LC diminui significativamente a latência de recolhimento da pata previamente submetida a injeção de carragenina e, aumenta a expressão de Fos no corno dorsal da medula espinal envolvido com a inervação desta região (TSURUOKA e WILLIS, 1996; WEI et al., 1999). Em contraposição a lesão unilateral do LC, seja ele o localizado no lado ispilateral ou contralateral, não promove alteração na latencia de recolhimento da pata posterior de ratos submetida a inflamação experimental (TSURUOKA e WILLIS, 1996; TSURUOKA et al., 2003). Este último trabalho sugere que a ativação unilateral do LC é suficiente para modular o processamento da informação nociceptiva no corno dorsal da medula espinal e, supostamente o mesmo ocorra no Sp5C. O LC consiste na principal aferência noradrenérgica para o Sp5C (FRITSCHY e GRZANNA, 1990) e, sua estimulação química ou elétrica desencadeia potente antinocicepção, principalmente via $\alpha_{2}$ adrenoceptores (JONES e GEBHART, 1986; JONES, 1991). Diante disso acreditamos que uma considerável parcela dos perfis de neurônios expressando Fos no LC, durante a fase aguda e a fase crônica ativa a monoartrite no CATM, evidencie a ativação de neurônios pertencentes a via noradrenérgica antinociceptiva para o Sp5C. Ademais, constatamos que durante a fase crônica da monoartrite no CATM a quantidade de perfis de neurônios Fos-IR no LC não diferiu do observado nos grupos controle, o que sugere uma atuação mais discreta da via noradrenérgica antinociceptiva ao nível do Sp5C nesta condição experimental.

Nós constatamos um aumento significante na quantidade de perfis de neurônios Fos positivos no NTS, durante a fase aguda e crônica ativa da monoartrite no CATM, o que está de acordo com estudos anteriores realizados na ATM e em joelhos de ratos (HATHAWAY et al., 1995; ZHOU et al., 1999; PINTO et al., 2007). Algumas evidências apontam o NTS como uma estrutura envolvida, dentre inúmeras 
outras funções, com a modulação da resposta nociceptiva. Os principais indícios provem de trabalhos que reportaram uma significativa alteração na transmissão da informação nociceptiva, no corno dorsal da medula espinal, após estimulação elétrica ou química do NTS (DU e ZHOU, 1990; RANDICH et al., 1988). Outro aspecto que reforça a participação deste núcleo no processamento da informação nociceptiva advém de estudos hodológicos, os quais reportaram como suas principais aferências, centros comprovadamente envolvidos com a nocicepção, como a PAG (BANDLER e TORK, 1987), a RVM (SIM e JOSEPH, 1992) e corno dorsal da medula espinal e o Sp5C (GAMBOA-ESTEVES et al., 2001). Alguns trabalhos que se utilizaram de traçamento neuronal reportaram conexões recíprocas entre o Sp5C e o NTS (DE-SOUSA-BUCK et al., 2001). No entanto, como o NTS está diretamente envolvido com mecanismos regulatórios envolvendo o sistema cardiovascular, digestório e respiratório, consequentemente este núcleo é uma área crucial na qual as projeções nociceptivas e autonômicas podem ser integradas e moduladas de maneira simultânea e, auxiliar, desta forma na composição da complexidade da dor orofacial (ABRAM et al., 1983; ANDERSON et al., 1990; ZHAMIR e MAIXNER, 1986). Diante disto, sugerimos que a grande quantidade de perfis de neurônios Fos-IR observada no NTS no presente trabalho, nas duas situações em que supostamente a dor se mostrava mais intensa, a artrite na ATM em suas fases aguda e crônica ativa, seja o reflexo da multiplicidade de funções reguladas pelo NTS que forma afetadas pela inflamação, como nocicepção, respostas cardiovasculares, digestivas e respiratórias.

Em resumo, nossos resultados demonstraram que durante as fases aguda $\mathrm{e}$ crônica ativa da monoartrite no CATM do rato, o Sp5C e a maioria dos centros de modulação da dor (PAG, RVM, CVLM, LC e NTS) estão intensamente ativados. No entanto durante a vigência de monoartrite na fase crônica no CATM, a ativação neuronal se mostra significante na zona de transição $\mathrm{Sp} 5 \mathrm{C} / \mathrm{Sp} 5 \mathrm{I}$, zona de transição Sp5C/C1,C2 e na PAG, ao passo que nos demais centros de modulação da resposta nociceptiva estudados, a quantidade de neurônios imunoarreativos ao marcador de ativação neuronal, Fos, retorna aos seus níveis basais. Sendo assim, são necessários estudos complementares, para que se possa confirmar o efetivo nível 
de ativação dos centros de modulação da dor, durante a vigência de dor crônca na ATM. 


\section{CONCLUSÕES GERAIS}


A análise dos resultados obtidos no presente trabalho nos permitiu concluir que:

1. a inervação autonômica da ATM do rato é representada por um grande contingente de fibras nervosas simpáticas e, uma discreta quantidade de fibras nervosas parassimpáticas. A constituição neuroquímica de tais fibras é consideravelmente complexa, no que se refere a expressão de TH, NPY e VIP, exibindo as fibras nervosas simpáticas os seguintes fenótipos: exclusivamente TH-IR (raras), TH/NPY-IR, TH/NPY/VIP-IR, enquanto que as fibras parassimpáticas se mostraram exclusivamente VIP-IR.

2. tanto as fibras e terminações nervosas simpáticas quanto as parassimpáticas foram encontradas predominantemente na circunjacência de vasos sanguíneos ou, isoladas no tecido conjuntivo, aparentemente sem estabelecerem contato com elementos vasculares, especialmente da membrana sinovial.

3. o Sp5C e a PAG, mostra-se intensamente ativados em todas as fases da monoartrite induzida no CATM (fase aguda, crônica e crônica-ativa), ao passo que a maioria dos centros nervosos moduladores da dor (RVM, CVLM, LC e NTS) apresentam uma quantidade significativamente aumentada de neurônios imunoarreativos ao marcador de ativação neuronal, Fos, apenas durante a fases aguda e crônica ativa dessa monoartrite. 
REFERÊNCIAS BIBLIOGRÁFICAS 


\section{REFERÊNCIAS BIBLIOGRÁFICAS ${ }^{1}$}

ABBADIE, C.; BESSON, J. M. C-fos expression in rat lumbar spinal cord during the development of adjuvant-induced arthritis. Neuroscience, v. 48, p. 985-993, 1992.

ABE, K.; TILAN, J.U.; ZUKOWSKA, Z. NPY and NPY receptors in vascular remodeling. Curr. Top. Med. Chem., v. 7, p. 1704-1709, 2007.

ABELLI, L.; GEPPETTI, P.; MAGGI, C.A. Relative contribution of sympathetic and sensory nerves to thermal nociception and tissue trophism in rats. Neuroscience, $v$. 57, p. 739-745, 1993.

ABRAM, S.E.; KOSTREVA, D.R.; HOPP, F.A.; KAMPINE, J.P. Cardiovascular responses to noxious radiant heat in anesthetized cats. Am. J. Physiol., v. 245, p. 576-580, 1983.

ACKERMANN, P.W.; LI, J.; FINN, A.; AHMED, M.; KREICBERGS, A. Autonomic innervation of tendons, ligaments and joint capsules. A morphologic and quantitative study in the rat. J. Orthop. Res., v. 19, p. 372-378, 2001.

AHMED, M.; BJURHOLM, A.; SCHULTZBERG, M.; THEODORSSON, E.; KREICBERGS, A. Increased levels of substance $P$ and calcitonin gene-related peptide in rat adjuvant arthritis. A combined immunohistochemical and radioimmunoassay analysis. Arthritis Rheum., v. 38, p. 699-709, 1995.

ALSTERGREN, P.; APPELGREN, A.; APPELGREN, B.; KOPP, S.; LUNDEBERG, T.; THEODORSSON, E. Co-variation of neuropeptide $\mathrm{Y}$, calcitonin gene-related peptide, substance $P$ and neurokinin $A$ in joint fluid from patients with temporomandibular joint arthritis. Arch. Oral Biol., v. 40, p. 127-135, 1995.

ALSTERGREN, P.; ERNBERG, M.; KOPP, S.; LUNDEBERG, T.; THEODORSSON, E. TMJ pain in relation to circulating neuropeptide $Y$, serotonin, and interleukin-1 beta in rheumatoid arthritis. J. Orofac. Pain., v. 13, p. 49-55, 1999.

ALSTERGREN, P.; KOPP, S. Prostaglandin E2 in temporomandibular joint synovial fluid and its relation to pain and inflammatory disorders. J. Oral Maxillofac. Surg., v. 58, p. 180-186, 2000.

APPELGREN, A.; APPELGREN, B.; ERIKSSON, S.; KOPP, S.; LUNDEBERG, T.; NYLANDER, M.; THEODORSSON, E. Neuropeptides in temporomandibular joints with rheumatoid arthritis: a clinical study. Scand. J. Dent. Res., v. 99, p. 519-521, 1991.

${ }^{1}$ De acordo com:

ASSOCIAÇÃO BRASILEIRA DE NORMAS TÉCNICAS. NBR 6023: Informação e documentação: referências: elaboração. Rio de Janeiro, 2002. 
AVERY, J. K.; COX, C. F.; CHIEGO, D. J. JR. Presence and location of adrenergic nerve endings in the dental pulps of mouse molars. Anat. Rec., v. 198, p. 59-71, 1980.

BADE, H.; SCHENCK, C.; KOEBKE, J. Clinical comparison of temporomandibular joint sound auscultation and emission imaging studies. J. Orofac. Pain, v. 8, p. 5560, 1994.

BANDLER, R.; TORK, I. Midbrain periaqueductal grey region in the cat has afferent and efferent connections with solitary tract nuclei. Neurosci. Lett., v. 74, p. 257-262, 1987.

BASBAUM, A.I.; FIELDS, H.L. Endogenous pain control systems: brainstem spinal pathways and endorphin circuitry. Annu. Rev. Neurosci., v. 7, p. 309-338, 1984.

BEDOUI, S.; KAWAMURA, N.; STRAUB, R.H; PABST, R.; YAMAMURA, T.; VON HÖRSTEN, S.J Relevance of neuropeptide $Y$ for the neuroimmune crosstalk. J. Neuroimmunol., v. 134, 1-11, 2003.

BEITZ, A.J. The nuclei of origin of brainstem serotonergic projections to the rodent spinal trigeminal nucleus. Neurosci. Lett., v. 32, p. 223-228, 1982.

BEITZ, A.J.; MULLETT, M. A.; WEINER, L. L. The periaqueductal gray projections to the rat spinal trigeminal, raphe magnus, gigantocellular pars alpha and paragigantocellular nuclei arise from separate neurons. Brain Res., v. 288, p. 307314, 1983.

BEITZ, A.J.; CLEMENTS, J.R.; ECKLUND, L.J.; MULLETT, M.M. The nuclei of origin of brainstem enkephalin and cholecystokinin projections to the spinal trigeminal nucleus of the rat. Neuroscience, v. 20, p. 409-425, 1987.

BENJAMIN, M.; RALPHS, J. R. Biology of fibrocartilage cells. Int. Rev. Cytol., v. 233, p. 1-45, 2004.

BEREITER, D.A.; HATHAWAY, C.B.; BENETTI, A.P. Caudal portions of the spinal trigeminal complex are necessary for autonomic responses and display Fos-like immunoreactivity after corneal stimulation in the cat. Brain Res., v. 657, p. 73-82, 1994.

BEREITER, D.A.; BEREITER, D.F. Morphine and NMDA receptor antagonism reduce $\mathrm{c}$-fos expression in spinal trigeminal nucleus produced by acute injury to the TMJ region. Pain, v. 85, p. 65-77, 2000.

BEREITER, D.A.; HIRATA, H.; HU, J.W. Trigeminal subnucleus caudalis: beyond homologies with the spinal dorsal horn. Pain, v. 88, p. 221-224, 2000. 
BEREITER, D.A. Sex differences in brainstem neural activation after injury to the TMJ region. Cells Tissues Organs., v.169, p. 226-237, 2001.

BEREITER, D.A.; SHEN, S.; BENETTI, A.P. Sex differences in amino acid release from rostral trigeminal subnucleus caudalis after acute injury to the TMJ region. Pain, v. 98, p. 89-99, 2002.

BEREITER, D.A.; OKAMOTO, K.; BEREITER, D.F. Effect of persistent monoarthritis of the temporomandibular joint region on acute mustard oil-induced excitation of trigeminal subnucleus caudalis neurons in male and female rats. Pain, v. 117, p. 5867, 2005.

BERKOVITZ, B.K.; PACY, J. Age changes in the cells of the intra-articular disc of the temporomandibular joints of rats and marmosets. Arch. Oral Biol., v. 45, p. 987-995, 2000.

BERMEJO, A.; GONZALEZ, O.; GONZALEZ, J.M. The pig as an animal model for experimentation on the temporomandibular articular complex. Oral Surg. Oral Med. Oral Pathol., v. 75, p. 18-23, 1993.

BILEVICIUTE, I.; LUNDEBERG, T.; EKBLOM, A.; THEODORSSON, E. Bilateral changes of substance $\mathrm{P}_{-}$, neurokinin $\mathrm{A}_{-}$, calcitonin gene-related peptide- and neuropeptide $Y$-like immunoreactivity in rat knee joint synovial fluid during acute monoarthritis. Neurosci. Lett., v. 153, p. 37-40, 1993.

BILEVICIUTE, I.; LUNDEBERG, T.; EKBLOM, A.; THEODORSSON, E. Substance $\mathrm{P}-$, neurokinin $\mathrm{A}-$, calcitonin gene-related peptide- and neuropeptide $\mathrm{Y}$-like immunoreactivity (-LI) in rat knee joint synovial fluid during acute monoarthritis is not correlated with concentrations of neuropeptide-LI in cerebrospinal fluid and plasma. Neurosci. Lett., v. 167, p. 145-148, 1994.

BILLIAU, A.; MATTHYS, P. Modes of action of Freund's adjuvants in experimental models of autoimmune diseases. J Leukoc Biol., v. 70, p. 849-860, 2001.

BILLINGHAM, M.E.; GORDON, A.H. The role of the acute phase reaction in inflammation. Agents Actions., v. 6, p. 195-200, 1976.

BLOMQVIST, A.; CRAIG, A.D. Organization of spinal and trigeminal input to the PAG. In: DEPAULIS, A.; BANDLER, R. (Ed.). The Midbrain Periaqueductal Gray Matter: Functional, Anatomical and Neurochemical Organization. New York: Plenum Press, 1991. p. 345-363.

BLUMBERG, H.; JÄNIG, W. Changes of reflexes in vasoconstrictor neurons supplying the cat hindlimb following chronic nerve lesions: a model for studying mechanisms of reflex sympathetic dystrophy?. J. Auton. Nerv. Syst., v. 7, p. 399411, 1983. 
BOUVIER, M. Effects of age on the ability of the rat temporomandibular joint to respond to changing functional demands. J. Dent. Res., v.67, p. 1206-1212, 1988.

BOWKE, R.M.; SONEA, I.M.; VEX, K.B.; CARON, J.P. Substance P innervation of equine synovial membranes: joint differences and neural and nonneural receptor localizations. Neurosci. Lett., v. 164, p. 76-80, 1993.

BRAGDON, E.E.; LIGHT, K.C.; COSTELLO, N.L.; SIGURDSSON, A.; BUNTING, S.; BHALANG, K.; MAIXNER, W. Group differences in pain modulation: pain-free women compared to pain-free men and to women with TMD. Pain, v. 96, p. 227-237, 2002.

BROTON, J.G.; HU, J.W.; SESSLE, B.J. Effects of temporomandibular joint stimulation on nociceptive and nonnociceptive neurons of the cat's trigeminal subnucleus caudalis (medullary dorsal horn). J. Neurophysiol., v. 59, p. 1575-1589, 1988.

BUTLER, S.H.; GODEFROY, F.; BESSON, J.M.; WEIL-FUGAZZA, J. A limited arthritic model for chronic pain studies in the rat. Pain, v. 48, p. 73-81, 1992.

CARLSSON, G.E.; LE RESCHE, L. Epidemiology of temporomandibular disorders. In: SESSLE, B. J.; BRYANT, P. S.; DIONNE, R. A. (Ed). Temporomandibular Disorders and Related Pain Conditions. Seattle: IASP Press, 1995. p. 211-226.

CARSTENS, E.; WATKINS, L.R. Inhibition of the responses of neurons in the rat spinal cord to noxious skinheating by stimulation in midbrain periaqueductal gray or lateralreticular formation. Brain Res., v. 382, p. 266-277, 1986.

CARSTENS, E.E. Endogenous pain suppression mechanisms. J. Am. Vet. Med. Assoc., v. 191, p. 1203-1206, 1987.

CARVALHO, R.S.; YEN, E.H.; SUGAR, D.M. The effect of growth on collagen and glycosaminoglycans in the articular disc of the rat temporomandibular joint. Arch. Oral Biol., v. 38, p. 457-466, 1993.

CASATTI, C.A.; FRIGO, L.; BAUER, J.A. Origin of sensory and autonomic innervation of the rat temporomandibular joint: a retrograde axonal tracing study with the fluorescent dye fast blue. J. Dent. Res., v. 78, p.776-784, 1999.

CASCONE, P.; VETRANO, S.; NICOLAI, G.; FABIANI, F. Temporomandibular joint biomechanical restrictions: the fluid and synovial membrane. J. Craniofac. Surg., v. 10, p. 301-307, 1999.

CHAUDHARY, P.; BAUMANN, T.K. Expression of VPAC2 receptor and PAC1 receptor splice variants in the trigeminal ganglion of the adult rat. Brain Res. Mol. Brain Res., v. 104, p. 137-142, 2002. 
CHIBA, T. Fine structures of the baroreceptor nerve terminals in the carotid sinus of the dog. J. Eletron Micros., v. 21, p. 139-148, 1972.

CHRISTENSEN, L.V.; ZIEBERT, G.J. Effects of experimental loss of teeth on the temporomandibular joint. J. Oral Rehabil., v. 13, p. 587-598, 1986.

CLARK, F.M.; PROUDFIT, H.K. The projection of locus coeruleus neurons to the spinal cord in the rat determined by anterograde tracing combined with immunocytochemistry. Brain Res., v. 538, p. 231-45, 1991.

CLARK, F.M.; YEOMANS, D.C.; PROUDFIT, H.K. The noradrenergic innervation of the spinal cord: differences between two substrains of Sprague-Dawley rats determined using retrograde tracers combined with immunocytochemistry. Neurosci Lett., v. 125, p. 155-158, 1991.

COBOS, A.; LIMA, D.; ALMEIDA, A.; TAVARES, I. Brain afferents to the lateral caudal ventrolateral medulla: a retrograde and anterograde tracing study in the rat. Neuroscience, v.120, p. 485-498, 2003.

COGGESHALL, R.E. Fos, nociception and the dorsal horn. Prog. Neurobiol., v. 77, p. 299-352, 2005.

COGGESHALL, R.E.; LEKAN, H.A. Methods for determinind numbers of cells and synapses: a case for more uniform standards of review. J. Comp. Neurol., v. 364, p. 6-15, 1996.

COUVINEAU, A.; LACAPERE, J.J.; TAN, Y.V.; ROUYER-FESSARD, C.; NICOLE, P.; LABURTHE, M. Identification of cytoplasmic domains of hVPAC1 receptor required for activation of adenylyl cyclase. Crucial role of two charged amino acids strictly conserved in class II G protein-coupled receptors. J. Biol. Chem., v. 278, p. 24759-24766, 2003.

DAMICO, J.P. Expressão de neuropeptídeos em neurônios que inervam a articulação temporomandibular do rato, em condições de normalidade e inflamação induzida. 123 f. Dissertação (Mestrado em Biologia Celular e Tecidual) - Instituto de Ciências Biomédicas, Universidade de São Paulo, São Paulo, 1998.

DAWSON, N.J.; HELLON, R.F.; HUBBARD, J.I. Cell responses evoked by tooth pulp stimulation above the marginal layer of the cat's trigeminal nucleus caudalis. $\mathbf{J}$. Comp. Neurol., v. 193, p. 983-994, 1980.

DELGADO, M.; ABAD, C.; MARTINEZ, C.; JUARRANZ, M.G.; ARRANZ, A.; GOMARIZ, R.P.; LECETA, J. Vasoactive intestinal peptide in the immune system: potential therapeutic role in inflammatory and autoimmune diseases. J. Mol. Med., v. 80, p. 16-24, 2002. 
DELGADO, M.; ABAD, C.; MARTINEZ, C.; LECETA, J.; GOMARIZ, R.P. Vasoactive intestinal peptide prevents experimental arthritis by downregulating both autoimmune and inflammatory components of the disease. Nat. Med., v. 7, p. 56356-56358, 2001.

DELGADO, M.; GANEA, D. Vasoactive intestinal peptide inhibits IL-8 production in human monocytes by downregulating nuclear factor kappaB-dependent transcriptional activity. Biochem. Biophys. Res. Commun., v. 302, p. 275-283, 2003.

DELGADO, M.; POZO, D.; GANEA, D. The significance of vasoactive intestinal peptide in immunomodulation. Pharmacol. Rev., v. 56, p. 249-290, 2004.

DENADAI-SOUZA, A.; CAMARGO, L.D.; RIBELA, M.T.; KEEBLE, J.E.; COSTA, S.K.; MUSCARÁ, M.N. Participation of peripheral tachykinin NK(1) receptors in the carrageenan-induced inflammation of the rat temporomandibular joint. Eur. J. Pain., 2008.

DE SOUSA BUCK , H.; CAOUS, C.A.; LINDSEY, C.J. Projections of the paratrigeminal nucleus to the ambiguus, rostroventrolateral and lateral reticular nuclei, and the solitary tract. Auton. Neurosci., v. 87, p. 187-200, 2001.

DI ROSA M, SORRENTINO L. The mechanism of the inflammatory effect of carrageenin. Eur. J. Pharmacol., v. 4, p. 340-342, 1968.

DI ROSA, M. Biological properties of carrageenan. J. Pharm. Pharmacol., v. 24, p. 89-102, 1972.

DIJKGRAAF, L. C.; DE BONT, L. G.; BOERING, G.; LIEM, R. S. Function, biochemistry, and metabolism of the normal synovial membrane of the temporomandibular joint: a review of the literature. J. Oral Maxillofac. Surg., v. 54, p. 95-100, 1996.

DIJKGRAAF, L.C.; DE BONT, L.G.; BOERING, G.; LIEM R.S. Structure of the normal synovial membrane of the temporomandibular joint: a review of the literature. J. Oral Maxillofac. Surg., v. 54, p. 332-338, 1996.

DONALDSON, K.W. Rheumatoid diseases and the temporomandibular joint: a review. Cranio, v. 13, p. 264-269, 1995.

DONALDSON, L.F. Unilateral arthritis: Contralateral affects. Trends Neurosci., v. 22, p. 495-496, 1999.

DONALDSON, L.F.; SECKL, J.R.; MCQUEEN, D.S. A discrete adjuvant-induced monoarthritis in the rat: effects of adjuvant dose. J. Neurosci. Methods., v. 49, p. 510, 1993. 
DONOSO, M.V.; DELPIANO, A.M.; HUIDOBRO-TORO, J.P. Modulator role of neuropeptide $Y$ in human vascular sympathetic neuroeffector junctions. EXS., v. 95, p. 65-76, 2006.

DU, H. J.; ZHOU, S. Y. Involvement of solitary tract nucleus in control of nociceptive transmission in cat spinal cord neurons. Pain, v. 40, p. 323-331, 1990.

DUBNER, R.; SESSLE, B.J.; STOREY, A.T. The neural basis of oral and facial function. New York: Plenum, 1978.

DWORKIN, S.F.; HUGGINS, K.H.; LERESCHE, L.; VON KORFF, M.; HOWARD, J.; TRUELOVE, E.; SOMMERS, E. Epidemiology of signs and symptoms in temporomandibular disorders: clinical signs in cases and controls. J. Am. Dent. Assoc., v. 120, p. 273-281, 1990.

ELENKOV, I. J.; CHROUSOS, G. P.; WILDER, R. L. Neuroendocrine regulation of IL12 and TNF-alpha/IL-10 balance. Clinical implications. Ann. N. Y. Acad. Sci., v. 917, p. 94-105, 2000.

ELFVIN, L.G.; HOLMBERG, K.; ALDSKOGIUS, H. Coexistence of enkephalin- and tyrosine hydroxylase-like immunoreactivities in nerve fibers of the temporomandibular joint capsule of the guinea pig. Anat. Rec., v. 251, p. 226-229, 1998.

ELFVIN, L.G.; HOLMBERG, K.; JOHANSSON, J.; ALDSKOGIUS, H. The innervation of the synovium of the knee joint in the guinea pig: an immunohistochemical and ultrastructural study. Anat. Embryol., v. 197, p. 293-303, 1998.

ERVOLINO, E. Influência da inervação simpática sobre a expressão de substância $P$ e peptídeo relacionado ao gene da calcitonina, em neurônios do gânglio trigeminal, que inervam a articulação temporomandibular, submetida a inflamação induzida. 112 f. Dissertação (Mestrado em Biologia Celular e Tecidual) - Instituto de Ciências Biomédicas, Universidade de São Paulo, São Paulo, 2001.

FAHRENKRUG, J.; HANNIBAL, J.; TAMS, J.; GEORG, B. Immunohistochemical localization of the VIP1 receptor (VPAC1R) in rat cerebral blood vessels: relation to PACAP and VIP containing nerves. J. Cereb. Blood Flow Metab., v. 20, p. 1205$1214,2000$.

FIELDS, H.L.; BASBAUM, A.I. Central nervous system mechanisms of pain modulation. In: WALL, P. D.; MELZACK, R. (Ed.). Textbook of pain. London: Churchill Livingstone, 1999, p. 309-329,

FIELDS, H.L.; HEINRICHER, M.M.; MASON, P. Neurotransmitters in nociceptive modulatory circuits. Annu. Rev. Neurosci., v. 14, p. 219-245, 1991. 
FIELDS, H.L; BASBAUM, A.I. Endogenous pain control mechanisms. In: WALL, P. D.; MELZACK, R. (Ed.). Textbook of pain. London: Churchill Livingstone, 1989. p. 206-217.

FILLINGIM, R.B.; MAIXNER, W.; KINCAID, S.; SIGURDSSON, A.; HARRIS, M.B. Pain sensitivity in patients with temporomandibular disorders: relationship to clinical and psychosocial factors. Clin. J. Pain., v. 12, p. 260-269, 1996.

FAY R, KUBIN L. Pontomedullary distribution of 5-HT2A receptor-like protein in the rat. J. Comp. Neurol., v. 418, p. 323-345, 2000.

FLAKE, N.M.; BONEBREAK, D.B.; GOLD, M.S. Estrogen and inflammation increase the excitability of rat temporomandibular joint afferent neurons. J. Neurophysiol., v. 93, p. 1585-1597, 2005.

FLAKE, N.M.; GOLD, M.S. Inflammation alters sodium currents and excitability of temporomandibular joint afferents. Neurosci. Lett., v. 384, p.294-299, 2005.

FOEY, A.D.; FIELD, S.; AHMED, S.; JAIN, A.; FELDMANN, M.; BRENNAN, F.M.; WILLIAMS, R. Impact of VIP and CAMP on the regulation of TNF-alpha and IL-10 production: implications for rheumatoid arthritis. Arthritis Res. Ther., v. 5, p. 317328, 2003.

FOONG, F.W.; DUGGAN, A.W. Brain-stem areas tonically inhibiting dorsal horn neurones: studies with microinjection of the GABA analogue piperidine-4-sulphonic acid. Pain, v. 27, p. 361-371, 1986.

FRITSCHY, J.M.; GRZANNA, R. Demonstration of two separate descending noradrenergic pathways to the rat spinal cord: evidende for an intragriseal trajectory of locus coeruleus axons in the superficial layers of the dorsal horn. J. Comp. Neurol., v. 291, p. 553-582, 1990.

FUNK, R.H.; TISCHENDORF, R.; BRATENGEIER, H. Microendoscopy of the synovial vasculature in the rabbit knee joint. Microvasc. Res., v. 50, p. 45-55, 1995.

GAMBOA-ESTEVES, F.O.; TAVARES, I.; ALMEIDA, A.; BATTEN, T.F.; MCWILLIAM, P.N.; LIMA, D. Projection sites of superficial and deep spinal dorsal horn cells in the nucleus tractus solitarii of the rat. Brain Res., v. 921, p. 195-205, 2001.

GANEA, D.; DELGADO, M. The neuropeptides VIP/PACAP and T cells: inhibitors or activators?. Curr. Pharm., v. 9, p. 997-1004, 2003.

GAO, K.; MASON, P. Serotonergic Raphe magnus cells that respond to noxious tail heat are not ON or OFF cells. J. Neurophysiol., v. 84, p. 1719-1725, 2000. 
GARCIA-LEME, J.; HAMAMURA, L.; LEITE, M.P.; ROCHA E SILVA, M. Pharmacological analysis of the acute inflammatory process induced in the rat's paw by local injection of carrageenan and by heating. Br. J. Pharmac., v. 48, p. 88-96, 1973.

GEBHART, G.F.; OSSIPOV, M.H. Characterization of inhibition of the spinal nociceptive tail-flick reflex in the rat from the medullary lateral reticular nucleus. $\mathbf{J}$. Neurosci., v. 6, p. 701-713, 1986.

GEBHART, G. F.; RANDICH, A. Brainstem modulation of nociception. In: KLEMM, W. R.; VERTES, R. P. (Ed.). Brainstem Mechanisms of Behavior. New York: John Wiley \& Sons, 1990. p. 315-352.

GONZALEZ-REY, E.; DELGADO, M. Vasoactive intestinal peptide and regulatory Tcell induction: a new mechanism and therapeutic potential for immune homeostasis. Trends Mol. Med., v. 13, p. 241-251, 2007.

GONZALEZ-REY, E.; FERNANDEZ-MARTIN, A.; CHORNY, A.; DELGADO, M. Vasoactive intestinal peptide induces CD4+,CD25+ $\mathrm{T}$ regulatory cells with therapeutic effect in collagen-induced arthritis. Arthritis Rheum., v. 54, p. 864-876, 2006.

GREEN, P.G.; BASBAUM, A.I.; LEVINE, J.D. Sensory neuropeptide interactions in the production of plasma extravasation in the rat. Neuroscience, v. 50, p. 745-749, 1992.

GREEN, P.G.; LUO, J.; HELLER, P.H.; LEVINE, J.D. Further substantiation of a significant role for the sympathetic nervous system in inflammation. Neuroscience, v. 55, p. 1037-1043, 1993.

GREEN, P.G.; LUO, J.; HELLER, P.H.; LEVINE, J.D.. Further substantiation of a significant role for the sympathetic nervous system in inflammation. Neuroscience, v. 55, p. $1037-1043,1993$.

GRIFFIN, C.J.; HARRIS, R. Innervation of the temporomandibular joint. Austr. Dent. J., v. 20, p. 78-85, 1975.

GRIFFIN, C.J.; HAWTHORN, R.; HARRIS, R. Anatomy and histology of the human temporomandibular joint. Monogr. Oral Sci., v. 4, p. 1-26, 1975.

GRIGNARI, G.; ZUCCHELLA, M.; BELAI BEYENE, N.; BROCCHIERI, A.; SAPORITI, A. ; CHERIE LIGNIERE, E. L. Levels of different metabolites of arachidonic acid in synovial fluid of patients with arthrosis or rheumatoid arthritis. Minerva Med., v. 87,.p. 75-79, 1996. 
GUTIÉRREZ-CAÑAS, I.; JUARRANZ, Y.; SANTIAGO, B.; MARTÍNEZ, C.; GOMARIZ, R.P.; PABLOS, J.L.; LECETA, J. Immunoregulatory properties of vasoactive intestinal peptide in human $T$ cell subsets: implications for rheumatoid arthritis. Brain Behav. Immun., v. 22, p. 312-317, 2008.

GRUBB, B. D.; STILLER, R. U.; SCHAIBLE, H. G. Dynamic changes in the receptive field properties of spinal cord neurons with ankle input in rats with chronic unilateral inflammation in the ankle region. Exp. Brain Res., v. 92, p. 441-452, 1993.

GUTKIND, J.S.; KURIHARA, M.; CASTRÉN, E.; SAAVEDRA, J.M. Autoradiographic quantification of vasoactive intestinal peptide binding sites in sections from human blood mononuclear cell pellets. Neuropsychopharmacology, v. 1, p. 251-255, 1988.

GUZZO, M.L.; FARSKY, S.H.; DE NUCCI, G.; ANTUNES, E.; SILVA, M.A.; MELLO, S.B. Role of kinins and nitric oxide on the rabbit arthritis induced by Bothrops jararaca venom. Toxicon, v. 38, p. 1535-1546, 2000.

HAEUCHI, Y.; MATSUMOTO, K.; ICHIKAWA, H.; MAEDA, S. Immunohistochemical demonstration of neuropeptides in the articular disk of the human temporomandibular joint. Cells Tissues Organs., v. 164, p. 205-211, 1999.

HALL, J.G.; DUGGAN, A. W.; MORTON, C.R.; JOHNSON, S. M. The location of brainstem neurones tonically inhibiting dorsal horn neurones of the cat. Brain Res., v. 244 , p. $215-222.1982$.

HANESCH, U.; HEPPELMANN, B.; SCHMIDT, R. F. Quantification of cat's articular afferents containing calcitonin gene-related peptide or substance $P$ innervating normal and acutely inflamed knee joints. Neurosci. Lett., v. 233, p. 105-108, 1997.

HARRIS, J. A. Using c-fos as a neural marker of pain. Brain Res. Bull., v. 45, p. 1-8, 1998.

HATHAWAY, C.B.; HU, J. W.; BEREITER, D.A. Distributionof Fos-like immunoreactivity in the caudal brainstem of the ratfollowing noxious chemical stimulation of the temporomandibular joint. J. Comp. Neurol., v. 356, p. 444-456, 1995.

HENDERSON, B.; EDWARD, J.C. W. The synovial lining in health and disease. London: Chapman and Hall, 1987.

HEINRICHER, M.M.; KAPLAN, H.J. GABA-mediated inhibition in the rostral ventromedial medulla: role in nociceptive modulation in the lightly anesthetized rat. Pain, v. 47, p. 105-113, 1991. 
HOFFMAN, G.E.; LYO, D. Anatomical markers of activity in neuroendocrine systems: are we all 'fos-ed out' ?. J. Neuroendocrinol., v. 14, p. 259-268, 2002.

HOHEISEL, U.; MENSE, S.; SCHEROTZKE, R. Calcitonin gene-related peptideimmunoreactivity in functionally identified primary afferent neurones in the rat. Anat. Embryol., v. 189, p. 41-49, 1994.

HOLZER, P. Neurogenic vasodilatation and plasma leakage in the skin. Gen. Pharmacol., v. 30, p. 5-11, 1998.

HONORÉ, P.; CHAPMAN, V.; BURITOVA, J.; BESSON, J. M. When is the maximal effect of pre-administered systemic morphine on carrageenin evoked spinal c-Fos expression in the rat?. Brain Res., v. 705, p. 91-96, 1995.

HOOTMAN, J.M.; HELMICK, C.G. Projections of US prevalence of arthritis and associated activity limitations. Arthritis Rheum., v. 54, p. 226-229, 2006.

HU, J.W.; SESSLE, B.J. Comparison of responses of cutaneous nociceptive and nonnociceptive brain stem neurons in trigeminal subnucleus caudalis (medullary dorsal horn) and subnucleus oralis to natural and electrical stimulation of tooth pulp. J. Neurophysiol., v. 52, p. 39-53, 1984.

HUANG, W.J.; WANG, B.R.; YAO, L.B.; HUANG, C.S.; WANG, X.; ZHANG, P.; JIAO, X.Y.; DUAN, X.L.; CHEN, B.F.; JU, G. Activityof p44/42 MAP kinase in the caudal subnucleus of trigeminal spinalnucleus is increased following perioral noxious stimulation in themouse. Brain Res., v. 861, p. 181-185, 2000.

ICHIKAWA, H.; WAKISAKA, S.; MATSUO, S.; AKAI, M. Peptidergic innervation of the temporomandibular disk in the rat. Experientia, v. 45, p. 303-304, 1989.

IMBE, H.; DUBNER, R.; REN, K. Masseteric inflammation-induced Fos protein expression in the trigeminal interpolaris/caudalis transition zone: contribution of somatosensory-vagal-adrenal integration. Brain Res., v. 845, p.165-175, 1999.

IMBE, H.; OKAMOTO, K.; AIKAWA, F.; KIMURA, A.; DONISHI, T.; TAMAI, Y.; IWAILIAO, Y.; SENBA, E. Effects of peripheral inflammation on activation of p38 mitogenactivated protein kinase in the rostral ventromedial medulla. Brain Res., v. 1134, p. 131-139, 2007.

IWANAGA, T.; SHIKICHI, M.; KITAMURA, H.; YANASE, H.; NOZAWA-INOUE, K. Morphology and functional roles of synoviocytes in the joint. Arch. Histol. Cytol., v. 63, p. 17-31, 2000.

IZUMI, H. Nervous control of blood flow in the orofacial region. Pharmacol. Ther., v. 81, p. 141-161, 1999. 
IZUMI, H. Functional roles played by the sympathetic supply to lip blood vessels in the cat. Am. J. Physiol., v. 277, p. 682-689, 1999.

JACQUIN, M.F.; SEMBA, K.; EGGER, M.D.; RHOADES, R.W. Organization of HRPlabeled trigeminal mandibular primary afferent neurons in the rat. J. Comp. Neurol., v. 215 , p. $397-420,1983$.

JÄNIG, W.; KOLLMANN, W. The involvement of the sympathetic nervous system in pain. Possible neuronal mechanisms. Arzneimittelforschung., v. 34, p. 1066-1073, 1984.

JANSS, A.J.; GEBHART, G.F . Spinal monoaminergic receptors mediate the antinociception produced by glutamate in the medullary lateral reticular nucleus. $\mathbf{J}$. Neurosci., v. 7, p. 2862-2873,1987.

JANSS, A.J.; GEBHART, G.F. Quantitative characterization and spinal pathway mediating inhibition of spinalnociceptive transmission from the lateral reticular nucleus in the rat. J. Neurophysiol., v. 59, p. 226-247, 1988.

JENSEN, T.S.; YAKSH, T.L. Spinal monoamine and opiate systems partly mediate the antinociceptive effects produced by glutamate at brainstem sites. Brain Res., v. 321, p. 287-297, 1984.

JIN, S.X.; ZHUANG, Z.Y.; WOOLF, C.J.; JI, R.R. p38mitogen-activated protein kinase is activated after a spinal nerveligation in spinal cord microglia and dorsal root ganglion neurons andcontributes to the generation of neuropathic pain. J. Neurosci., v. 23, p. 4017-4022, 2003.

JOHANSSON, A.S.; ISACSSON, G.; ISBERG, A.; GRANHOLM, A. C. Distribution of substance $P$-like immunoreactive nerve fibers in temporomandibular joint soft tissues of monkey. Scand. J. Dent. Res., v. 94, p. 225-232, 1986.

JONES, S.L. Descending control of nociception. In: GILDENBERG P. L. (Ed.). The initial processing of pain end its descending control: Spinal and Trigeminal Systems. Karger: Basel, 1992. p. 203-295.

JONES, SL.; GEBHART, G.F. Quantitative characterization of ceruleospinal inhibition of nociceptive transmission in the rat. J. Neurophysiol., v. 56, p. 1397-1410, 1986.

JONES, S.L.; GEBHART, G.F. Inhibition of spinal nociceptive transmission from the midbrain, pons and medulla in the rat: activation of descending inhibition by morphine, glutamate and electrical stimulation. Brain Res., v. 460, p. 281-296, 1988.

JUARRANZ, Y.; ABAD, C.; MARTINEZ, C.; ARRANZ, A.; GUTIERREZ-CAÑAS, I.; ROSIGNOLI, F.; GOMARIZ, R.P.; LECETA, J. Protective effect of vasoactive intestinal peptide on bone destruction in the collagen-induced arthritis model of rheumatoid arthritis. Arthritis Res. Ther., v. 7, p. 1034-10 45, 2005. 
JUST, S.; HEPPELMANN, B. Neuropeptide $Y$ changes the excitability of fine afferent units in the rat knee joint. Br. J. Pharmacol., v. 132, p. 703-708, 2001.

KAMELCHUK, L.S.; MAJOR, P.W. Degenerative disease of the temporomandibular joint. J. Orofac. Pain., v. 9, p. 168-180, 1995.

KAWAMURA, Y.; MAJIMA, T.; KATO, I. Physiologic role of deep mechanoreceptor in temporomandibular joint capsule. J. Osaka Univ. Dent. Sch., v. 7, p. 63-76, 1967.

KAWASAKI, Y.; KOHNO, T.; ZHUANG, Z.Y.; BRENNER, G.J.; WANG, H.; VAN DER MEER, C.; BEFORT, K.; WOOLF, C.J.; JI ,R.R. Ionotropicand metabotropic receptors, protein kinase $A$, protein kinase $C$, and Src contribute to $C$-fiber-induced ERK activation and cAMP responseelement-binding protein phosphorylation in dorsal horn neurons, leading to central sensitization. J. Neurosci., v. 24, p. 8310-832, 2004.

KEAY, K.; BANDLER, R. Deep and superficial noxious stimulation increases Fos-like immunoreactivity in different regions of the midbrain periaqueductal grey of the rat. Neurosci. Lett., v. 154, p. 23-26, 1993.

KELLER, H.; MOFFETT, B.C. JR. Nerve endings in the temporomandibular joint of the Rhesus Macaque. Anat. Rec., v. 160, p. 587-594, 1968.

KIDO, M.A.; KIYOSHIMA, T.; KONDO, T.; AYASAKA, N.; MOROI, R.; TERADA, Y.; TANAKA, T. Distribution of substance $P$ and calcitonin gene-related peptide-like immunoreactive nerve fibers in the rat temporomandibular joint. J. Dent. Res., v. 72, p. 592-598, 1993.

KIDO, M.A.; KONDO, T.; AYASAKA, N.; TERADA, Y.; TANAKA, T. The peripheral distribution of trigeminal nerve fibres in the rat temporomandibular joint studied by an anterograde axonal transport method with wheat germ agglutinin-horseradish peroxidase. Arch. Oral Biol., v. 36, p.397-400, 1991.

KIDO, M.A.; KIYOSHIMA, T.; IBUKI, T.; SHIMIZU, S.; KONDO, T.; TERADA, Y.; TANAKA, T. A topographical and ultrastructural study of sensory trigeminal nerve endings in the rat temporomandibular joint as demonstrated by anterograde transport of wheat germ agglutinin-horseradish peroxidase (WGA-HRP). J. Dent. Res., v. 74, p. 1353-1359, 1995.

KIDO, M.A.; ZHANG, J.Q.; MUROYA, H.; YAMAZA, T.; TERADA, Y.; TANAKA T. Topography and distribution of sympathetic nerve fibers in the rat temporomandibular joint: immunocytochemistry and ultrastructure. Anat. Embryol., v. 203, p. 357-366, 2001.

KIDO, M.A.; ZHANG, J.Q.; MUROYA, H.; YAMAZA, T.; TERADA, Y.; TANAKA, T. Topography and distribution of sympathetic nerve fibers in the rat temporomandibular joint: immunocytochemistry and ultrastructure. Anat. Embryol. (Berl)., v. 203, p. 357-366, 2001. 
KIRKER-HEAD, C.A.; CHANDNA, V.K.; AGARWAL, R.K.; MORRIS, E.A.; TIDWELL, A.; O'CALLAGHAN, M.W.; RAND, W.; KUMAR, M.S. Concentrations of substance P and prostaglandin E2 in synovial fluid of normal and abnormal joints of horses. Am. J. Vet. Res., v. 61, p. 714-718, 2000.

KLATT, D.S; GUINAN, M.J; CULHANE, E.S; CARSTEN, E.; WATKINS, L.R. The dorsal raphe nucleus: a re-evaluation of its proposed role in opiate analgesia systems. Brain Res., v. 447, p. 246-252, 1988.

KOOP, S. The influence of neuropeptides, serotonin, and interleukin 1 beta on temporomandibular joint pain and inflammation. J. Oral Maxilofac. Surg., v. 56, p. 189-191, 1998.

KOVÁCS, K.J. c-Fos as a transcription factor: a stressful (re)view from a functional map. Neurochem. Int., v. 33, p. 287-297, 1998.

KUMMER, W. Three types of neurochemically defined autonomic fibres innervate the carotid baroreceptor and chemoreceptor regions in the guinea-pig. Anat. Embryol. (Berl)., v. 181, p. 477-489, 1990.

LABURTHE, M.; COUVINEAU, A.; MARIE, J.C. VPAC receptors for VIP and PACAP. Receptors Channels., v. 8, p. 137-153, 2002.

LANTÉRI-MINET, M.; DE POMMERY, J.; HERDEGEN, T.; WEIL-FUGAZZA, J.; BRAVO, R.; MENÉTREY, D. Differentialtime course and spatial expression of Fos, Jun, and Krox-24 proteins inspinal cord of rats undergoing subacute or chronic somatic inflammation. J. Comp. Neurol., v. 333, p. 223-235, 1993.

LANG, B.; LI, Y.Q. Serotoninergic neurons in the brainstem expressing FOS protein after orofacial noxious stimulation: an immunocytochemical double-labeling study. J. Hirnforsch., v. 39, p. 263-268, 1998.

LAPA, R.C.; BAUER, J.A.; LINDSEY, C.J. A comparative and ultrastructural study of synaptic contacts established by primary sensory fibers in the spinal trigeminal nucleus of the rat. Tissue Cell., v. 28, p. 569-576,1996.

LAUCHER, J.; DELTON, I.; BUDA, M.; TAPPAZ, M. The habituation of brainstem catecholaminergic groups to chronic dailyrestraint stress is stress specific like that of thehypothalamo-pituitary-adrenal axis. Brain Res., v. 638, p. 196-202, 1994.

LAWAND, N.B.; MCNEARNEY, T.; WESTLUND, K.N. Amino acid release into the knee joint: key role in nociception and inflammation. Pain, v.86, p. 69-74, 2000.

LAWSON, S.N.; CREPPS, B.A.; PERL, E.R. Relationship of substance $P$ to afferent characteristics of dorsal root ganglion neurones in guinea-pig. J. Physiol., v. 505, p. 177-191, 1997. 
LAWSON, S.N.; PERRY, M.J.; PRABHAKAR, E.; MCCARTHY, P.W. Primary sensory neurones: neurofilament, neuropeptides, and conduction velocity. Brain Res. Bull., v. 30, p. 239-243, 1993.

LEAH, J.D.; PORTER, J.; DE-POMMERY, J.; MENETREY, D.; WEIL-FUGUZZA, J. Basal and touch-evoked fos-like immunoreactivity during experimental inflammation in the rat. Pain, v. 67, p. 307-316, 1996.

LEBLANC, G.G., TRIMMER, B.A., LANDIS, S.C. Neuropeptide Y-like immunoreactivity in rat cranial parasympathetic neurons: coexistence with vasoactive intestinal peptide and choline acetyltransferase. Proc. Natl. Acad. Sci. U. S. A., v. 84, p. 3511-3515, 1987.

LEBLANC, G.G.; LANDIS, S.C.Target specificity of neuropeptide Y-immunoreactive cranial parasympathetic neurons. J. Neurosci., v. 8, p. 146-155, 1988.

LECETA, J.; MARTÍNEZ, C.; DELGADO, M.; GARRIDO, E.; GOMARIZ, R.P. Expression of vasoactive intestinal peptide in lymphocytes: a possible endogenous role in the regulation of the immune system. Adv. Neuroimmunol., v. 6, p. 29-36, 1996.

LEE, H. S.; KIM, M. A.; WATERHOUSE, B. D. Retrograde double-labeling study of common afferent projections to the dorsal raphe and the nuclear core of the locus coeruleus in the rat. J. Comp. Neurol., v. 481, p. 179-193, 2005.

LEVINE, J.D.; COLLIER, D.H.; BASBAUM, A. I.; MOSKOWITZ, M.A.; HELMS, C.A. Hypothesis: the nervous system may contribute to the pathophysiology of rheumatoid arthritis. J. Rheumatol., v. 12, p. 406-411, 1985.

LEVINE, R.; MORGAN, M.M.; CANNON, J.T.; LIEBESKIND, J.C. Stimulation of the periaqueductal gray matter of the rat produces a preferential ipsilateral antinociception. Brain Res., v. 567, p. 140-144, 1991.

LEVINE, J.D.; FIELDS, H.L.; BASBAUM, A.I. Peptides and the primary afferent nociceptor. J. Neuroscience, v. 13, p. 2273-2286, 1993.

LEVINE, J.D.; KHASAR, S.G.; GREEN, P.G. Neurogenic inflammation and arthritis. Ann. N. Y. Acad. Sci., v. 1069, p. 155-167, 2006.

LI, Y.Q; TAKADA, M.; MATSUZAKI, S.; SHINONAGA, Y.; MIZUNO, N. Identification of periaqueductal gray and dorsal raphe nucleus neurons projecting to both the trigeminal sensory complex and forebrain structures: a fluorescent retrograde doublelabeling study in the rat. Brain Res., v. 623, p. 267-277, 1993.

LIU, H. P.; TAY, S. S.; LEONG, S. K. An ultrastructural study of the innervation of the guinea pig pancreas. J. Hirnforsch., v. 38; p. 107-117, 1997. 
LOBBEZOO, F.; DRANGSHOLT, M.; PECK, C.; SATO, H.; KOPP, S.; SVENSSON, $P$. Topical review: new insights into the pathology and diagnosis of disorders of the temporomandibular joint. J. Orofac. Pain, v. 18, p. 181-191, 2004.

LUNDEBERG, T.; ALSTERGREN, P.; APPELGREN, A.; APPELGREN, B.; CARLESON, J.; KOPP, S.; THEODORSSON, E. A model for experimentally induced temperomandibular joint arthritis in rats: effects of carrageenan on neuropeptide-like immunoreactivity. Neuropeptides, v. 30, p. 37-41, 1996.

LU, J.; HATHAWAY, C.B.; BEREITER, D.A. Adrenalectomy enhances Fos-like immunoreactivity within the spinal trigeminal nucleus induced by noxious thermal stimulation of the cornea. Neuroscience, v. 54, p. 809-818, 1993.

MA, Q.P.; WOOLF, C.J. Effect of acute stimulation on Fos expression in spinal neurons in the presence of persisting C-fiber activity. Brain Res., v. 719, p. 104-111, 1996.

MCGOWAN, M.K.; HAMMOND, D.L. Antinociception produced by microinjection of Lglutamate into the ventromedial medulla of the rat: mediation by spinal GABAA receptors. Brain Res., v. 620, p. 86-96, 1993.

MAGDALENA, C.M.; NAVARRO, V.P.; PARK, D.M.; STUANI, M.B.; ROCHA, M.J. Cfos expression in rat brain nuclei following incisor tooth movement. J. Dent. Res., v. 83, p. 50-54, 2004.

MAGDALENA, C.M.; NAVARRO, V.P.; PARK, D.M.; STUANI, M.B.; ROCHA, M.J. Cfos expression in rat brain nuclei following incisor tooth movement. J. Dent. Res., v. 83 , p. 50-54, 2004.

MAIXNER, W.; FILLINGIM, R.; BOOKER, D.; SIGURDSSON, A. Sensitivity of patients with painful temporomandibular disorders to experimentally evoked pain. Pain, v. 63, p. 341-351, 1995.

MAIXNER, W.; FILLINGIM, R.; SIGURDSSON, A.; KINCAID, S.; SILVA, S. Sensitivityof patients with painful temporomandibular disorders to experimentallyevoked pain: evidence for altered temporal summation of pain. Pain, v. 76, p. 71-81, 1998.

MAREK, P.; YIRMIYA, R.; LIEBESKIND, J. C. Stimulation-produced analgesia in the mouse: evidence for laterality of opioid mediation. Brain Res., v. 541, p. 154-156, 1991.

MARFURT, C.F.; RAJCHERT, D.M. Trigeminal primary afferent projections to "nontrigeminal" areas of the rat central nervous system. J. Comp. Neurol., v. 303, p. 489$511,1991$. 
MARTINEZ, C.; DELGADO, M.; ABAD, C.; GOMARIZ, R.P.; GANEA, D.; LECETA, J. Regulation of VIP production and secretion by murine lymphocytes. J. Neuroimmunol., v. 93, p. 126-138, 1999.

MAYER, D.J.; LIEBESKIND, J.C. Pain reduction by focal electrical stimulation of the brain: an anatomical and behavioral analysis. Brain Res., v. 68, p. 73-93, 1974.

MAYER, D. J.; WOLFLE, T. L.; AKIL, H.; CARDER, B.; LIEBESKIND, J. C. Analgesia from electrical stimulation in the brainstem of the rat. Science, v. 174, p. 1351-1354, 1971.

MCCARTHY, P.W.; LAWSON, S.N. Cell type and conduction velocity of rat primary sensory neurons with substance P-like immunoreactivity. Neuroscience, v. 28, p. 745-753, 1989.

MCNEARNEY, T., SPEEGLE, D., LAWAND, N., LISSE, J., WESTLUND, K.N. Excitatory amino acid profiles of synovial fluid from patients with arthritis. J. Rheumatol., v. 27, p. 739-745, 2000.

MEDEIROS, M.A.; CANTERAS, N.S.; SUCHECKI, D.; MELLO, L.E. c-Fos expression induced by electroacupuncture at the Zusanli point in rats submitted to repeated immobilization. Braz. J. Med. Biol. Res., v. 36, p. 1673-1684, 2003.

MELIA, K.R.; RYABININ, A.E.; SCHROEDER, R.; BLOOM, F.E.; WILSON, M.C. Induction and habituation of immediate early gene expression in rat brain by acute and repeated restraint stress. J. Neurosci., v. 14, p. 5929-5938, 1994.

MENG, I.D.; HU, J.W.; BEREITER, D.A. Differential effects of morphine on cornealresponsive neurons in rostral versus caudal regions of spinal trigeminal nucleus in the rat. J. Neurophysiol., v. 79, p. 2593-2602, 1998.

MESSINA, A.; BELL, C.Morphometric and neurochemical changes in rat superior cervical ganglion during growth and adulthood. Mech. Ageing. Dev., v. 67, 211-223, 1993.

MESSLINGER K. What is a nociceptor? Anaesthesist., v. 46, p. 142-153, 1997.

MIAO, F.J.; JÄNIG, W.; LEVINE, J. Role of sympathetic postganglionic neurons in synovial plasma extravasation induced by bradykinin. J. Neurophysiol., v. 75, p. 715-724, 1996.

MICHEL, M.C.; BECK-SICKINGER, A.; COX, H.; DOODS, H.N.; HERZOG, H.; LARHAMMAR, D.; QUIRION, R.; SCHWARTZ, T.; WESTFALL, T. XVI. International Union of Pharmacology recommendations for the nomenclature of neuropeptide $Y$, peptide YY, and pancreatic polypeptide receptors. Pharmacol. Rev., v. 50, p. 143150, 1998. 
MIKI, K.; ZHOU, Q.Q.; GUO, W.; GUAN, Y.; TERAYAMA, R.; DUBNER, R.; REN, K. Changes in gene expression and neuronal phenotype in brain stem pain modulatory circuitry after inflammation. J. Neurophysiol., v. 87, p. 750-760, 2002.

MILAM, S.B.; KLEBE, R.J.; TRIPLETT, R.G.; HERBERT, D. Characterization of the extracellular matrix of the primate temporomandibular joint. J. Oral Maxillofac. Surg., v. 49, p. 381-391, 1991.

MILLAN, M.J. Descending control of pain. Prog. Neurobiol., v. 66, p. 355-474, 2002.

MILLER, L.E.; GRIFKA, J.;SCHÖLMERICH, J.; STRAUB, R.H. Norepinephrine from synovial tyrosine hydroxylase positive cells is a strong indicator of synovial inflammation in rheumatoid arthritis. J. Rheumatol., v. 29, p. 427-435, 2002.

MILLER, L.E.; JÜSTEN, H.P.; SCHÖLMERICH, J.; STRAUB, R.H. The loss of sympathetic nerve fibers in the synovial tissue of patients with rheumatoid arthritis is accompanied by increased norepinephrine release from synovial macrophages. FASEB J., v. 14, p. 2097-2107, 2000.

MITCHENS, D.M.; FRIES, J.F. An analysis of the American Rheumatism Association criteria for rheumatoid arthritis. Arthritis Rheum., v. 25, p. 481-487, 1982.

MOLINOFF, P.B., AXELROD, J. Biochemistry of catecholamines. Annu. Rev. Biochem., v. 40, p. 465-500, 1971.

MOLINOFF, P.B.; AXELROD, J. Biochemistry of catecholamines. Annu. Rev. Biochem., v. 40, p. 465-500, 1971.

MORANI, V.; PREVIGLIANO, V.; SCHIERANO, G.M.; RAMIERI G. Innervation of the human temporomandibular joint capsule and disc as revealed by immunohistochemistry for neurospecific markers. J. Orofac. Pain, v. 8, p, 36-41, 1994.

MORGAN, J.I.; CURRAN, T. Stimulus-transcription coupling in the nervous system: involvement of the inducible proto-oncogenes fos and jun. Annu. Rev. Neurosci., v. 14, p. 421-451, 1991.

MORGAN, M.M.; GRISEL, J.E.; ROBBINS, C.S.; GRANDY, D.K. Antinociception mediated by the periaqueductal gray is attenuated by orphanin FQ. Neuroreport., $v$. 8, p. 3431-3434, 1997.

NAKAMURA, M.; FERREIRA, S.H. A peripheral sympathetic component in inflammatory hyperalgesia. Eur. J. Pharmacol., v. 135, p. 145-153, 1987.

NAKAMURA, M.; FERREIRA, S.H.A peripheral sympathetic component in inflammatory hyperalgesia. Eur. J. Pharmacol., v. 135, p. 145-153, 1987. 
NASUTION ID, SHIGENAGA Y. Ascending and descending internuclear projections within the trigeminal sensory nuclear complex. Brain Res., v. 425, p. 234-247, 1987.

NATIELLA, J. R.; BURCH, L.; FRIES, K. M.; UPTON, L. G.; EDSBERG, L. E. Analysis of the collagen I and fibronectin of temporomandibular joint synovial fluid and discs. J. Oral Maxillofac. Surg., v. 67, 105-113, 2009.

NAVEILHAN, P.; CANALS, J.M.; ARENAS, E.; ERNFORS, P. Distinct roles of the Y1 and $\mathrm{Y} 2$ receptors on neuropeptide $\mathrm{Y}$-induced sensitization to sedation. J. Neurochem., v. 78, p. 1201-1207, 2001.

NESS, T.J.; GEBHART, G.F. Quantitative comparison of inhibition of visceral and cutaneous spinal nociceptive transmission from the midbrain and medulla in the rat. J. Neurophysiol., v. 58, p. 850-865, 1987.

NETO, F.L.; SCHADRACK, J.; ABLEITNER, A.; CASTRO-LOPES, J.M.; BARTENSTEIN, P.; ZIEGLGÄNSBERGER, W.; TÖLLE, T.R. Supraspinal metabolic activity changes in the rat during adjuvant monoarthritis. Neuroscience, v. 94, p. 607-621, 1999.

NEUGEBAUER, V.; GEISSLINGER, G.; RÜMENAPP, P.; WEIRETTER, F.; SZELENYI, I.; BRUNE, K.; SCHAIBLE, H.G. Antinociceptive effects of R(-)- and S(+)flurbiprofen on rat spinal dorsal horn neurons rendered hyperexcitable by an acute knee joint inflammation. J. Pharmacol. Exp. Ther., v. 275, p. 618-628, 1995.

NOBLE, H.W. Comparative functional anatomy of temporomandibular joint. Oral Sci. Rev., v. 2, p. 3-28, 1973.

NOZAWA-INOUE, K.; AMIZUKA, N.; IKEDA, N.; SUZUKI, A.; KAWANO, Y.; MAEDA. T. Synovial membrane in the temporomandibular joint--its morphology, function and development. Arch. Histol. Cytol., v. 66, p. 289-306, 2003

$\mathrm{OH}$, S. H.; IMBE, H.; IWAI-LIAO, Y. TMJ inflammation increases Fos expression in the nucleus raphe magnus induced by subsequent formalin injection of the masseter or hindpaw of rats. Okajimas Folia Anat. Jpn., v. 83, p. 43-52, 2006.

OHTORI, S.; TAKAHASHI, K.; CHIBA, T.; TAKAHASHI, Y.; YAMAGATA, M.; SAMEDA, H.; MORIYA, H. Fos expression in the rat brain and spinal cord evoked by noxious stimulation to low back muscle and skin. Spine., v. 25, p. 2425-2430, 2000.

OKAMOTO, K.; IMBE, H.; TASHIRO, A.; KIMURA, A.; DONISHI, T.; TAMAI, Y.; SENBA, E. The role of peripheral $5 \mathrm{HT} 2 \mathrm{~A}$ and $5 \mathrm{HT} 1 \mathrm{~A}$ receptors on the orofacial formalin test in rats with persistent temporomandibular joint inflammation. Neuroscience, v. 130, p. 465-474, 2005. 
OKAMOTO, K.; KIMURA, A.; DONISHI, T.; IMBE, H.; NISHIE, Y.; MATSUSHITA, H.; TAMAI, Y.; SENBA, E. Contribution of peripheral 5-HT2A or 5-HT3 receptors to Fos expression in the trigeminal spinal nucleus produced by acute injury to the masseter muscle during persistent temporomandibular joint inflammation in rats. Neuroscience, v. 143, p. 597-606, 2006.

OKAMOTO, K.; IMBE, H.; KIMURA, A.; DONISHI, T.; TAMAI, Y.; SENBA, E. Activation of central 5HT2A receptors reduces the craniofacial nociception of rats. Neuroscience, v. 147, p. 1090-1102, 2007.

PAXINOS, G.; WATSON, C. The rat brain in stereotaxic coordinates. San Diego: Academic Press, 1998.

PAXINOS G. The rat nervous system. New York: Academic Press, 1995.

PEARSE, D.D.; BUSHELL, G.; LEAH, J.D. Jun,Fos and Krox in the thalamus after Cfiber stimulation: coincident-input-dependent expression, expression across somatotopicboundaries, and nucleolar translocation. Neuroscience, v. 107, p. 143159, 2001.

PERSON, C.M. Development of arthritis, periarthritis and periostitis in rats given adjuvants. Proceedings of the Society for Expermental Biology and Medicine., v. 91, p. 95-101, 1956.

PERROT S, GUILBAUD G. Pathophysiology of joint pain. Rev. Rhum. Engl. Ed., v. 63, p. 485-495, 1996.

PFALLER, K.; ARVIDSSON, J. Central distribution of trigeminal and upper cervical primary afferents in the rat studied by anterograde transport of horseradish peroxidase conjugated to wheat germ agglutinin. J. Comp. Neurol., v. 268, p. 91$108,1988$.

PIETTE, E. Anatomy of the human temporomandibular joint. An updated comprehensive review. Acta Stomatol. Belg., v. 90, p. 103-127, 1993.

PINTO, M.; LIMA, D.; TAVARES, I. Correlation of noxious evoked c-fos expression in areas of the somatosensory system during chronic pain: involvement of spinomedullary and intra-medullaryconnections. Neurosci. Lett., v. 409, p. 100-105, 2006.

PINTO, M.; LIMA, D.; TAVARES, I. Neuronal activation at the spinal cord and medullary pain control centers after joint stimulation: a c-fos study in acute and chronic articular inflammation. Neuroscience, v. 147, p. 1076-1089, 2007.

PIRTTINIEMI, P.; KANTOMAA, T.; SALO, L.; TUOMUNEN, M. Effect of reduced articular function on deposition of type I and type II collagens in the mandibular condylar cartilage of the rat. Arch. Oral Biol., v. 41, p. 127-131, 1996. 
POIGNONEC, S.; LAMAS, G.; GOUDOT, P.; SOUDANT, J. The temporomandibular joint: anatomy, physiology, clinical review. Ann. Radiol., v. 33, p. 363-371, 1990.

RANDICH, A.; ROOSE, M.G.; GEBHART, G.F. Characterization of antinociception produced by glutamate microinjection in the nucleus tractus solitarius and the nucleus reticularis ventralis. J. Neurosci., v. 8 p. 4675-4684, 1988.

REYNOLDS, D.V. Surgery in the rat during electrical analgesia induced by focal brain stimulation. Science, v. 164, p. 444-445, 1969.

ROBINSON PP, BOISSONADE FM, LOESCHER AR, SMITH KG, YATES JM, ELCOCK C, BIRD EV, DAVIES SL, SMITH PL, VORA AR. Peripheral mechanisms for the initiation of pain following trigeminal nerve injury. J. Orofac. Pain, v. 18, p. 287-292, 2004.

ROCHA, M.J.; HERBERT, H. Effects of anesthetics on Fos protein expression in autonomic brain nuclei related to cardiovascular regulation. Neuropharmacology, $v$. 36, p. 1779-1781, 1997.

RODELLA, L.; REZZANI, R.; GIOIA, M.; TREDICI, G.; BIANCHI, R. Expression of Fos immunoreactivity in the rat supraspinal regions following noxious visceral stimulation. Brain Res. Bull., v. 47, p. 357-366, 1998.

RODRIGUES, L.L.; OLIVEIRA, M.C.; PELEGRINI-DA-SILVA, A.; DE ARRUDA VEIGA, M.C.; PARADA, C.A.; TAMBELI, C.H. Peripheral sympathetic component of the temporomandibular joint inflammatory pain in rats. J. Pain, v. 7, p. 929-936, 2006.

SALVEMINI, D.; WANG, Z.Q.; WYATT, P.S.; BOURDON, D.M.; MARINO, M.H.; MANNING, P.T.; CURRIE, M.G. Nitric oxide: a key mediator in the early and late phase of carrageenan-induced rat paw inflammation. Br. J. Pharmacol., v. 118, p. 829-838, 1996.

SANDKUHLER, J.; HELMCHEN, C.; FU, Q. G.; Zimmermann, M. Inhibition of spinal nociceptive neurons by excitation of cell bodies or fibers of passage at various brainstem sites in the cat. Neurosci. Lett., v. 93, p. 67-72, 1988.

SANDOW, L.S.; HILL, E.C. Physiological and anatomical studies of the development of the sympathetic innervation to rat iris arterioles. J. Auton. Nerv. Syst., v. 77, p. 152-163, 1999.

SANTER, V.; SRIRATANA, A.; LOWTHER, D.A. Carrageenin-induced arthritis: V. A morphologic study of the development of inflammation in acute arthritis. Semin. Arthritis Rheum., v. 13, p. 160-168, 1983. 
SANDKÜHLER, J.; WILLMANN, E.; FU, Q.G. Characteristics of midbrain control of spinal nociceptive neurons and nonsomatosensory parameters in the pentobarbitalanesthetized rat. J. Neurophysiol., v. 65, p. 33-48, 1991.

SATO, T.; KITAGAWA, J.; REN, K.; TANAKA, H.; TANABE, A.; WATANABE, T.; MITSUHASHI, Y.; IWATA, K. Activation of trigeminal intranuclear pathway in rats with temporomandibular joint inflammation. J. Oral Sci., v. 47, p. 65-69, 2005.

SATOH, M.; OKU, R.; AKAIKE, A. Analgesia produced by microinjection of Lglutamate into the rostral ventromedial bulbar nuclei of the rat and its inhibition by intrathecal _-adrenergic blocking agents. Brain Res., v. 261, p. 361-364, 1983.

SCHADRACK, J.; CASTRO-LOPES, J. M.; AVELINO, A.; ZIEGLGÄNSBERGER, W.; TÖLLE, T. R. Modulated expression of $c$-Fos in the spinal cord following noxious thermal stimulation of monoarthritic rats. J. Neurosci. Res., v.53, p. 203-213, 1998.

SCHAIBLE, H.G.; JARROTT, B.; HOPE, P.J.; DUGGAN, A.W. Release of immunoreactive substance $P$ in the spinal cord during development of acute arthritis in the knee joint of the cat: a study with antibody microprobes. Brain Res., v. 529, p. 214-223, 1990.

SCHAIBLE, H.G.; SCHMIDT, R.F. Effects of an experimental arthritis on the sensory properties of fine articular afferent units. J. Neurophysiol., v. 54, p. 1109-1122, 1985.

SCHAIBLE, U.E.; VESTWEBER, D.; BUTCHER, E.G.; STEHLE, T.; SIMON, M.M. Expression of endothelial cell adhesion molecules in joints and heart during Borrelia burgdorferi infection of mice. Cell Adhes. Commun., v. 2, p. 465-479, 1994.

SCHMIDT, B.L.; POGREL, M.A.; NECOCHEA, M.; KEARNS, G. The distribution of the auriculotemporal nerve around the temporomandibular joint. Oral Surg. Oral Med. Oral Pathol. Oral Radiol. Endod., v. 86, p. 165-168, 1998.

SEDGWICK, A.D.; MOORE, A.R.; AL-DUAIJ, A.Y.; EDWARDS, J.C.; WILLOUGHBY, D.A.Studies into the influence of carrageenan-induced inflammation on articular cartilage degradation using implantation into air pouches. Br. J. Exp. Pathol., v. 66, p. 445-453, 1985.

SEIBERT, K.; ZHANG, Y.; LEAHY, K.; HAUSER, S.; MASFERRER, J.; PERKINS, W.; LEE, L.; ISAKSON, P. Pharmacological and biochemical demonstration of the role of cyclooxygenase 2 in inflammation and pain. Proc. Natl. Acad. Sci. U. S. A., v. 91, p. 12013-12017, 1994.

SENBA, E.; MATSUNAGA, K.; TOHYAMA, M.; NOGUCHI, K. Stress-induced c-fos expression in the rat brain: activation mechanism of sympathetic pathway. Brain Res. Bull., v. 31, p. 329-344, 1993. 
SEO, K.; FUJIWARA, N.; HU, J. W.; CAIRNS, B. E; SOMEYA, G. Intrathecal administration of 5-HT(3) receptor agonist modulates jaw muscle activity evoked by injection of mustard oil into the temporomandibular joint in the rat. Brain Res., v. 934, p. 157-161, 2002.

SESSLE, B. J. Acute and chronic craniofacial pain: Brainstem mechanisms of nociceptive transmission and neuroplasticity, and their clinical correlates. Crit. Rev. Oral Biol. Med., v.11, p. 57-91, 2000.

SESSLE BJ. Mechanisms of oral somatosensory and motor functions and their clinical correlates. J. Oral Rehabil., v. 33, p. 243-261, 2006.

SESSLE BJ. Peripheral and central mechanisms of orofacial pain and their clinical correlates. Minerva Anestesiol., v. 71, p. 117-136, 2005.

SESSLE BJ. The neural basis of temporomandibular joint and masticatory muscle pain. J. Orofac. Pain, v. 13, p. 238-245, 1999.

SHENKER, N.; HAIGH, R.; ROBERTS, E.; MAPP, P.; HARRIS, N.; BLAKE, D. Pain, neurogenic inflammation and symmetry in medical practice. Pain Rev., v. 8, p. 27-34, 2001.

SHIMIZU, S.; KIDO, M. A.; KIYOSHIMA, T.; TANAKA, T. Postnatal development of substance $\mathrm{P}$-, calcitonin gene-related peptide- and neuropeptide $\mathrm{Y}$-like immunoreactive nerve fibres in the synovial membrane of the rat temporomandibular joint. Arch. Oral Biol., v. 41, p. 749-759, 1996.

SIM, L.J.; JOSEPH, S.A. Efferent projection of the nucleus raphe magnus. Brain Res. Bull., v. 28, p. 679-682, 1992.

SLUKA, K.A.; WESTLUND, K.N. Spinal projections of the locus coeruleus and the nucleus subcoeruleus in the Harlan and the Sasco Sprague-Dawley rat. Brain Res., v. 579, p. 67-73, 1992.

STORER, R.J.; GOADSBY, P.J. Microiontophoretic application of serotonin $(5 \mathrm{HT}) 1 \mathrm{~B} / 1 \mathrm{D}$ agonists inhibits trigeminal cell firing in the cat. Brain, v. 120, p. 21712177, 1997.

SUN, D.; GUO, L.; REN, L. Electron microscopy of elastic system fibers in the rat mandibular joint. Zhonghua Kou Qiang Yi Xue Za Zhi., v. 32, p. 26-27, 1997.

SUN, W.; PANNETON, W.M. The caudal pressor area of the rat: its precise location and projections to the ventrolateral medulla. Am. J. Physiol. Regul. Integr. Comp. Physiol., v. 283, p. 768-778, 2002. 
SVENSSON, C.I.; MARSALA, M.; WESTERLUND, A.; CALCUTT, N.A.; CAMPANA, W.M.; FRESHWATER, J.D.; CATALANO, R.; FENG, Y.; PROTTER, A.A.; SCOTT, B.; YAKSH, T.L. Activationof p38 mitogen-activated protein kinase in spinal microglia is acritical link in inflammation-induced spinal pain processing. J. Neurochem., v. 86, p. 1534-44, 2003.

TAHMASEBI-SARVESTANI, A.; TEDMAN, R.A.; GOSS, A. Neural structures within the sheep temporomandibular joint. J. Orofac. Pain, v. 10, p. 217-231, 1996.

TAHMASEBI-SARVESTANI, A.; TEDMAN, R.; GOSS, A.N. Distribution and coexistence of neuropeptides in nerve fibres in the temporomandibular joint of late gestation fetal sheep. J. Anat., v. 191, p. 245-257, 1997.

TAKEUCHI, Y.; ISHII, N.; TODA, K. An in vitro temporomandibular joint-nerve preparation for pain study in rats. J. Neurosci. Methods, v. 30, p. 123-128, 2001.

TAKEUCHI, Y.; TODA, K. Subtypes of nociceptive units in the rat temporomandibular joint. Brain Res. Bull., v. 61(6), p. 603-608, 2003.

TANAKA, E.; DETAMORE, M.S.; MERCURI, L.G. Degenerative disorders of the temporomandibular joint: etiology, diagnosis and treatment. J. Dent. Res., v. 87, p. 296-307, 2008.

TAVARES, I.; ALMEIDA, A.; LIMA, D.; COIMBRA, A. The caudal ventrolateral medulla is reciprocally connected with the spinal cord. Soc. Neurosci. Abstr., v. 24, p. 393, 1998.

TAVARES, I.; ALMEIDA, A.; ALBINO-TEIXEIRA, A.; LIMA, D. Lesions of the caudal ventrolateral medulla block the hypertension-induced inhibition of noxious-evoked cfos expression in the rat spinal cord. Eur. J. Pain, v. 1, p. 149-160, 1997.

TAVARES, I.; LIMA, D. Descending projections from the caudal medulla oblongata to the superficial or deep dorsal horn of the rat spinal cord. Exp. Brain Res., v. 99, p. 455-463, 1994.

TAVARES, I.; LIMA, D. The caudal ventrolateral medulla as an important inhibitory modulator of pain transmission in the spinal cord. J. Pain., v. 3, p. 337-346, 2002.

TAVARES, I.; LIMA, D.; COIMBRA, A. The ventrolateral medulla of the rat is connected with the spinal cord dorsal horn an indirect descending pathway relayed in the A5 noradrenergic cell group. J. Comp. Neurol., v. 374, p. 84-95, 1996.

TERRIER, F.; HRICAK, H.; REVEL, D.; ALPERS, C.E.; REINHOLD, C.E.; LEVINE, J.; GENANT, H.K. Magnetic resonance imaging and spectroscopy of the periarticular inflammatory soft-tissue changes in experimental arthritis of the rat. Invest. Radiol., v. 20, p. 813-823, 1985. 
THOMAS, D.A.; MCGOWAN, M.K.; HAMMOND, D.L. Microinjection of baclofen in the ventromedial medulla of rats: antinociception at low doses and hyperalgesia at high doses. J. Pharmacol. Exp. Ther., v. 275, p. 274-284, 1995.

TRANZER, J.P.; THOENEN, H. Electronmicroscopic localization of 5hydroxydopamine (3,4,5-trihydroxy-phenyl-ethylamine), a new 'false' sympathetic transmitter. Experientia, v. 23, p. 743-745, 1967.

TSURUOKA, M.; ARAI, Y.C.P.; NOMURA, H.; MATSUTANI, K.; WILLIS, W.D. Unilateral hindpaw inflammation induces bilateral activation of the locus coeruleus and the nucleus subcoeruleus in the rat. Brain Res. Bull., v. 61, p. 117-123, 2003.

TSURUOKA, M.; WILLIS, W.D. Bilateral lesions in the area of the nucleus locus coeruleus affect the development of hyperalgesia during carrageenan- induced inflammation. Brain Res., v.726, p. 233-236, 1996.

UDDMAN, R.; GRUNDITZ, T.; KATO, J.; SUNDLER, F. Distribution and origin of nerve fibers in the rat temporomandibular joint capsule. Anat. Embryol., v. 197, p. 273-282, 1998.

URBAN, M.O.; JIANG, M.C.; GEBHART, G.F. Participation of central descending nociceptive facilitatory system in secondary hyperalgesia produced by mustard oil. Brain Res., v.737, p. 83-91, 1996.

VAN EDEN, W.; HOGERVORST, E.J.; VAN DER ZEE, R.; VAN EMBDEN, J.D.; HENSEN, E.J.; COHEN, I.R. The mycobacterial $65 \mathrm{kD}$ heat-shock protein and autoimmune arthritis. Rheumatol. Int., v. 9, p. 187-191, 1989.

VAN MAANEN, M.A.; VERVOORDELDONK, M.J.; TAK, P.P. The cholinergic antiinflammatory pathway: towards innovative treatment of rheumatoid arthritis. Nat. Rev. Rheumatol., v. 5, p. 229-232, 2009.

VAN MAANEN, M.A.; VERVOORDELDONK, M.J.; TAK, P.P. The cholinergic antiinflammatory pathway: towards innovative treatment of rheumatoid arthritis. Nat. Rev. Rheumatol., v. 5, p. 229-232, 2009.

VANDENABEELE, F.; DE BARI, C.; MOREELS, M.; LAMBRICHTS, I.; DELL'ACCIO, F.; LIPPENS, P.L.; LUYTEN, F.P. Morphological and immunocytochemical characterization of cultured fibroblast-like cells derived from adult human synovial membrane. Arch. Histol. Cytol., v. 66, p. 145-153, 2003.

VANEGAS, H.; SCHAIBLE, H.G. Descending control of persistent pain: inhibitory or facilitatory?. Brain Res. Brain Res. Rev., v. 46, p. 295-309, 2004.

VILENSKY, J.A.; COOK, J.A. Neurogenic acceleration of osteoarthritis. Curr. Opin. Rheumatol., v. 10, p. 251-255, 1998. 
VON KORFF, M.; DWORKIN, S.F.; LE RESCHE, L.; KRUGER, A. An epidemiologic comparison of pain complaints. Pain, v.32, p. 173-183, 1988.

WAUBEN, M.; WAGENARR-HILERS, J.P.A.; WAN EBEN, W. Autoimmune diseases models: a guide book, 1994.

WEI, F.; DUBNER, R.; REN, K. Nucleus reticularis gigantocellularis and nucleus raphe magnus in the brain stem exert opposite effects on behavioral hyperalgesia and spinal Fos protein expression after peripheral inflammation. Pain, v. 80, p. 127141, 1999.

WHITEHOUSE, M.W.; BECK, F.W. Standardisation of arthritogenic adjuvants for evaluating anti-inflammatory and immunosuppressant drugs. Agents Actions., v. 4,p. 227-229, 1974.

WIDENFALK, B.; WIBERG, M. Origin of sympathetic and sensory innervation of the temporomandibular joint. A retrograde axonal tracing study in the rat. Neurosci. Lett., v. 109, p. 30-35, 1990.

WIESENFELD-HALLIN, Z.; HALLIN, R.G. The influence of the sympathetic system on mechanoreception and nociception. A review. Hum. Neurobiol., v. 3, p. 41-46, 1984.

WILSON, N.H.; GARDNER, D.L. The microscopic structure of fibrous articular surfaces: a review. Anat. Rec., v. 209, p. 143-152, 1984.

WILLETTE, R.N.; BARCAS, P.P.; KRIEGER, A.J.; SAPRU, H.N. Vasopressor and depressor areas in the rat medulla. Identification by microinjection of L-glutamate. Neuropharmacology, v. 22, p. 1071-1079, 1983.

WINK, C.; ONGE, M. S.T.; ZIMNY, M.L. Neural elements in the human temporomandibular articular disk. J. Oral. Maxilofac. Surg., v. 50, p. 334-337, 1992.

YIN, H.; CHENG, H.; YU, M.; ZHANG, F.; LIN, J.; GAO, Y.; HAN, B.; ZHU, L. Vasoactive intestinal peptide ameliorates synovial cell functions of collagen-induced arthritis rats by down-regulating NF-kappaB activity. Immunol. Invest., v. 34, p. 153169, 2005.

YOSHIDA, H.; FUJITA, S.; NISHIDA, M.; IIZUKA, T. The expression of substance P in human temporomandibular joint samples: an immunohistochemical study. J. Oral Rehabil., v.26, p. 338-344, 1999.

YOSHINO, K.; KAWAGISHI, S.; AMANO, N. Morphological characteristics of primary sensory and post-synaptic sympathetic neurones supplying the temporomandibular joint in the cat. Arch. Oral Biol., v.43, p. 679-686, 1998.

ZAMIR, N.; MAIXNER, W. The relationship between cardiovascular and pain regulatory systems. Ann. N. Y. Acad. Sci., v. 46, p. 371-384, 1986. 
ZHOU, Q.; IMBE, H.; DUBNER, R.; REN, K. Persistent Fos protein expression after orofacial deep or cutaneous tissue inflammation in rats: implications for persistent orofacial pain. J. Comp. Neurol., v.412, p. 276-291, 1999.

ZIMMERMANN, M. Ethical guidelines for investigations of experimental pain in conscious animals. Pain, v. 16, p. 109-110, 1983.

ZIMNY, M.L. Mechanoreceptors in articular tissues. Am. J. Anat., v.182, p. 16-32, 1988.

ZUKOWSKA, Z.; PONS, J.; LEE, E.W.; LI, L. Neuropeptide Y: a new mediator linking sympathetic nerves, blood vessels and immune system?. Can. J. Physiol. Pharmacol., v. 81, p. 89-94, 2003. 